INSTITUTO DE PESQUISAS ENERGÉTICAS E NUCLEARES

Autarquia associada à Universidade de São Paulo

GERAÇÃO DE RESÍDUOS SÓLIDOS DE GALVANOPLASTIA EM REGIÕES DENSAMENTE POVOADAS - AVALIAÇÃO, INERTIZAÇÃO E DESTINAÇÃO

CLEITON DOS SANTOS MATTOS

Dissertação apresentada como parte dos requisitos para obtenção do Grau de Mestre em Ciências na Área de Tecnologia Nuclear Materiais.

Orientadora:

Dra. Sonia Regina Homem de Mello Castanho 


\section{DEDICATÓRIA}

Dedico este trabalho à minha querida esposa, que é tão especial a ponto de ser impossível definir. Junto a ela, dedico ao nosso filho, Natan, que acabou de nascer. 


\section{AGRADECIMENTOS}

Agradeço, em primeiro lugar, àquele que com entendimento fez os céus e a terra, porque as suas misericórdias duram para sempre e são a causa de não sermos consumidos.

Agradeço à minha esposa, por todo o seu amor, dedicação e compreensão, além de toda a ajuda prestada (que não foi pequena) durante este trabalho de mestrado.

Agradeço aos meus pais, por terem me ensinado o caminho em que se deve andar.

Agradeço à minha orientadora, Prof $=$. Dra. Sonia Regina Homem de Mello Castanho, pela confiança para a realização deste trabalho e por este tempo de caminhada, proporcionando crescimento pessoal e profissional.

Agradeço a todas as pessoas do Instituto de Pesquisas Tecnológicas IPT que contribuíram para a realização deste trabalho, sem os quais não teria sido possível sua conclusão, e ao instituto, propriamente dito, por ter proporcionado condições para o seu desenvolvimento.

Agradeço às pessoas envolvidas no Projeto de Unidades Móveis (PRUMO) do IPT, principalmente, seus coordenadores, pelo apoio para a realização deste trabalho. Foi por meio deste projeto que o trabalho foi idealizado.

Agradeço ao Instituto de Pesquisas Energéticas e Nucleares - IPEN, por oferecer condições para a realização deste trabalho e, particularmente, ao Dr. Antonio Carlos da Silva, pela colaboração técnica, além dos demais colegas deste instituto, pelo apoio recebido.

Agradeço aos proprietários das empresas que contribuíram com este trabalho, pois suas respostas aos questionários foram essenciais para a pesquisa. Agradeço pela visita recebida e por terem doado os resíduos sólidos galvânicos.

Agradeço às empresas que prestam serviço para a destinação dos resíduos sólidos, pelas informações para o trabalho.

Agradeço a toda minha família e aos amigos, pela especial atenção, dedicação e apoio. 
Entretanto, expomos sabedoria entre os experimentados; não, porém, a sabedoria deste século, nem a dos poderosos desta época, que se reduzem a nada; mas falamos a sabedoria de Deus em mistério, outrora oculta, a qual Deus preordenou desde a eternidade para a nossa glória; sabedoria essa que nenhum dos poderosos deste século conheceu; porque, se tivessem conhecido, jamais teriam crucificado o Senhor da glória; mas, como está escrito: nem olhos viram, nem ouvidos ouviram, nem jamais penetrou em coração humano o que Deus tem preparado para aqueles que o amam.

1Cor. 2.6-9 


\title{
GERAÇÃO DE RESÍDUOS SÓLIDOS DE GALVANOPLASTIA EM REGIÕES DENSAMENTE POVOADAS - AVALIAÇÃO, INERTIZAÇÃO E DESTINAÇÃO
}

\author{
Cleiton dos Santos Mattos
}

\section{RESUMO}

Os resíduos sólidos galvânicos despertam especial atenção, devido à sua composição tóxica. Tais resíduos geralmente são estocados nas empresas de galvanoplastia, criando um preocupante passivo ambiental, em particular, nas áreas densamente povoadas, como a zona leste da cidade de São Paulo, que, por sua vez, possui um pólo de empresas de galvanoplastia do setor de cromação. Face ao pressuposto, na primeira parte do trabalho, um estudo foi realizado com a compilação dos dados de empresas galvânicas situadas na zona leste de São Paulo, abordando aspectos socioeconômicos e de processo, que influenciam na geração e na destinação dos resíduos sólidos industriais. $\mathrm{Na}$ segunda parte do trabalho, amostras selecionadas de resíduos sólidos foram avaliadas quanto às suas características químicas e físico-químicas e foi apresentada a viabilidade do uso tecnológico visando o aproveitamento destes resíduos. Os principais resultados obtidos mostraram que nas dezessete empresas visitadas são geradas 106 toneladas de resíduos sólidos por ano e estes são armazenados em condições precárias, podendo afetar a população vizinha em caso de acidentes ambientais. Os resíduos constituídos majoritariamente por $\mathrm{Ni}, \mathrm{Cr}, \mathrm{B}, \mathrm{Cu}, \mathrm{Ca}, \mathrm{S}, \mathrm{C}, \mathrm{Na}, \mathrm{Fe}$ e $\mathrm{Zn}$, quando aquecidos até $1400^{\circ} \mathrm{C}$, apresentaram formações de compostos identificados como $\mathrm{Ca}_{2} \mathrm{Cr}_{2} \mathrm{O}_{5}$, $\mathrm{BaCrO}_{4}, \mathrm{NiCr}_{2} \mathrm{O}_{4}, \mathrm{CuCrO}_{2}, \mathrm{CaSO}_{4}, \mathrm{Ni}_{2} \mathrm{SiO}_{4}, \mathrm{NiO}$ e CuO. Estes compostos são difíceis de serem obtidos e, por si só, apresentam potencial para comercialização como matérias-primas para a produção de produtos cerâmicos. Os resíduos sólidos galvânicos foram incorporados em matrizes vítreas, indicando uma 
alternativa satisfatória e de baixo custo para a inertização dos constituintes nocivos à saúde. Os vidros obtidos apresentaram aspectos coloridos, podendo ser utilizados como produtos finais ou como matérias-primas para a produção de esmaltes cerâmicos ou pigmentos inorgânicos. Existem diversas possibilidades de destinação dos lodos galvânicos e, independente de qual seja adotada, conclui-se que é de extrema importância a sua retirada de dentro das empresas, para eliminar o enorme e crescente passivo ambiental. 


\title{
PRODUCTION OF SOLID GALVANIC WASTE IN DENSELY POPULATED AREAS - EVALUATION, INERTIZATION AND DISPOSAL
}

\author{
Cleiton dos Santos Mattos
}

\begin{abstract}
Solid galvanic waste has attracted special attention due to its toxic composition. These wastes are usually stored in galvanic companies, creating a worrying environmental liability, especially in densely populated areas, as eastern side of São Paulo city, which area has many galvanic companies of chroming sector. Therefore, on the first part of this research, a study was made with the collection of informations of the galvanic companies situated on the eastern side of São Paulo, considering the socioeconomics aspects and process, which interfere on the destination and generation of the industrials solid waste. On the second part of the research, selected samples of the solid waste were analyzed related to its chemical and physical-chemical characteristics and it was showed the viability of technological using viewing the utilization of this waste. The main results show that in the seventeen companies visited, 106 tons/year of solid waste have been produced and being stored in precarious conditions, may affecting the neighbor population in case of environment accidents. The waste mainly composed of $\mathrm{Ni}$, $\mathrm{Cr}, \mathrm{B}, \mathrm{Cu}, \mathrm{Ca}, \mathrm{S}, \mathrm{C}, \mathrm{Na}, \mathrm{Fe}$ and $\mathrm{Zn}$, when heated up to $1400^{\circ} \mathrm{C}$, showed compounds formations identified such as $\mathrm{Ca}_{2} \mathrm{Cr}_{2} \mathrm{O}_{5}, \mathrm{BaCrO}_{4}, \mathrm{NiCr}_{2} \mathrm{O}_{4}, \mathrm{CuCrO}_{2}$, $\mathrm{CaSO}_{4}, \mathrm{Ni}_{2} \mathrm{SiO}_{4}, \mathrm{NiO}$ and $\mathrm{CuO}$. This compounds are difficult to obtain and are economically important as raw materials for the ceramic products production. The solid galvanic waste were incorporated into the glassy matrix, indicating that this technique is a good alternative and with low cost for the inertization of these chemical compounds, which are harmful to the health. The glasses are colorful, and can be used as final products or as raw materials for the production of
\end{abstract}


ceramic enamel or inorganic pigments. There are many possibilities of destination of the galvanic waste and, independent of which one is adopted, it may be concluded that is of extreme importance to take it out of the companies, to eliminate the enormous and growing environmental liability. 


\section{SUMÁRIO}

Página

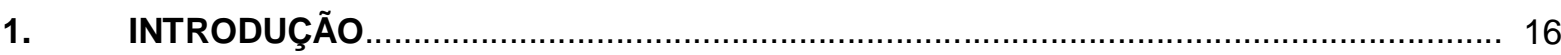

2. OBJETIVO

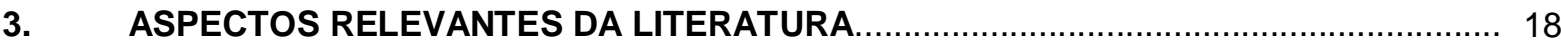

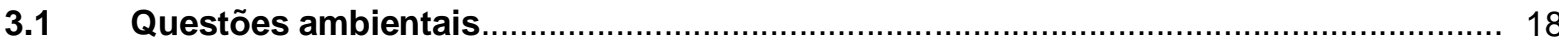

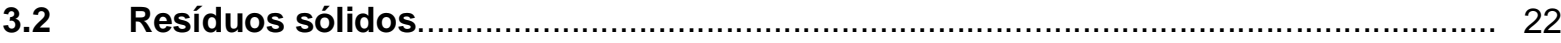

3.2.1 Tipos de tratamento dos resíduos sólidos galvânicos.................................................... 24

3.2.2 Inertização/estabilização de resíduos sólidos galvânicos................................................. 27

3.3 Vidros e revestimentos cerâmicos................................................................................ 29

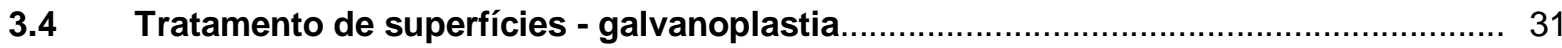

3.4.1 Galvanoplastia no Brasil e no Estado de São Paulo......................................................... 33

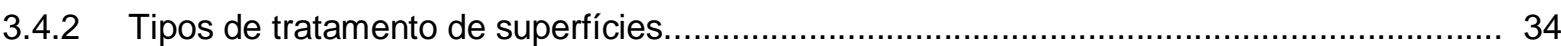

3.4.3 Etapas do processo de galvanoplastia.................................................................... 39

3.4.4 Riscos ocupacionais na galvanoplastia.................................................................... 40

3.4.5 Tratamento de efluentes na galvanoplastia.................................................................. 42

3.5 Micro e Pequenas Empresas (MPEs), meio ambiente e população............................. 43

3.6 Projeto de Unidades Móveis do setor de tratamento de superfícies (PRUMO/TS) ...... 46

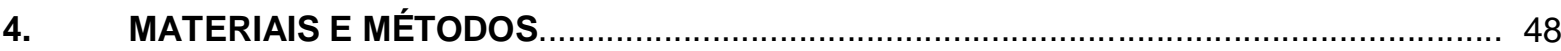

4.1 Parte A - Levantamento de dados nas empresas de galvanoplastia da zona leste da cidade de São Paulo

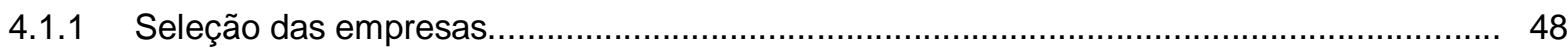

4.1.2 Levantamento de dados relativos à geração de resíduos sólidos galvânicos..................... 49

4.2 Parte B - Aplicação tecnológica para os resíduos sólidos galvânicos...................... 49

4.2.1 Seleção e coleta dos resíduos sólidos galvânicos para caracterização.............................. 49

4.2.2 Preparação de amostras e técnicas de caracterização................................................... 51 
4.2.3 Seleção de amostras para vitrificação .......................................................................... 56

4.2.4 Incorporação dos resíduos sólidos galvânicos em matrizes vítreas................................... 56

4.2.4.1 Cálculos de composição vítrea............................................................................. 56

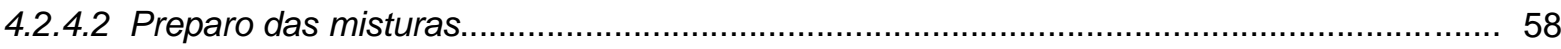

4.2.4.3 Condições de fusão e vertimento............................................................................ 59

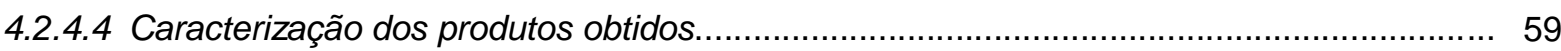

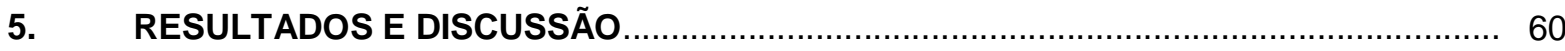

5.1 Parte A - Resultados obtidos dos questionários aplicados nas empresas de 60 galvanoplastia da zona leste da cidade de São Paulo.

5.1.1 Análise dos dados coletados nas empresas sobre a geração dos resíduos sólidos galvânicos.

5.1.2 Aspectos econômicos das destinações dos resíduos sólidos galvânicos.

5.2 Parte B - Resultados experimentais visando uma aplicação tecnológica para os resíduos sólidos galvânicos.

5.2.1 Caracterização química e físico-química dos resíduos sólidos galvânicos.

5.2.2 Obtenção de materiais vítreos com incorporação dos resíduos sólidos galvânicos............ 105

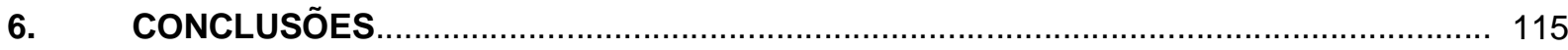

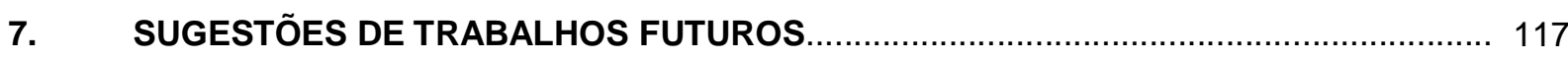
APÊNDICE - QUESTIONÁRIO ESTRUTURADO APLICADO NAS EMPRESAS DE 118
GALVANOPLASTIA 


\section{LISTA DE TABELAS}

TABELA 1 - Estabelecimentos de galvanoplastia e trabalhadores (Brasil, 2005)...................... 34

TABELA 2 - Estabelecimentos de galvanoplastia e trabalhadores (São Paulo, 2005)............. 34

TABELA 3 - Composições das soluções químicas utilizadas nas empresas de cromação...... 36

TABELA 4 - Dados populacionais, segundo IBGE, em 04/11/2010 ...................................... 46

TABELA 5 - Identificação dos RSGs coletados nas empresas.............................................. 51

TABELA 6 - Identificação das composições para obtenção dos materiais vítreos..................... 57

TABELA 7 - Substâncias utilizadas no preparo das misturas para a obtenção dos materiais

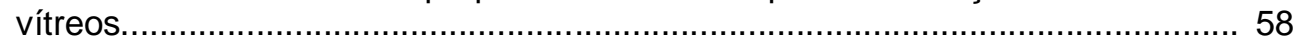

TABELA 8 - Principais dados coletados dos questionários - Parte 1 (aspectos

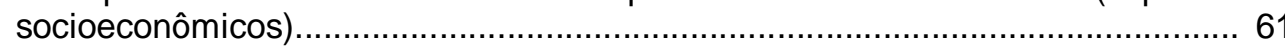

TABELA 9 - Principais dados coletados dos questionários - Parte 2 (aspectos do processo

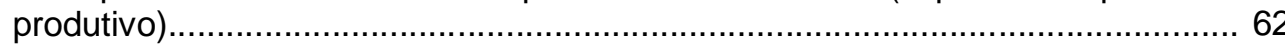

TABELA 10 - Principais dados coletados dos questionários - Parte 3 (aspectos sobre os resíduos sólidos galvânicos gerados)...................................................................... 63

TABELA 11 - Quantidade de resíduos sólidos gerados por ano nas empresas............................64 64

TABELA 12 - Resíduos sólidos gerados nas empresas de médio porte em relação às empresas de micro e pequeno porte................................................................. 66

TABELA 13 - Destinações possíveis para os RSGs e seus custos........................................... 76

TABELA 14 - Resultado dos elementos detectados nos RSGs, por FRX e EDS........................ 78

TABELA 15 - Resultado dos teores dos elementos nos RSGs, por ICP-AES, FAAS, gravimetria e titulação potenciométrica.......................................................... 79

TABELA 16 - Resultado dos compostos identificados por DRX na amostra RSG 1, após tratamentos térmicos.................................................................................... 83

TABELA 17 - Resultado dos compostos identificados por DRX na amostra RSG 2, após tratamentos térmicos................................................................................. 88

TABELA 18 - Resultado dos compostos identificados por DRX na amostra RSG 3, após tratamentos térmicos.................................................................................. 93

TABELA 19 - Resultado dos compostos identificados por DRX na amostra RSG 4, após tratamentos térmicos............................................................................. 98

TABELA 20 - Resultado dos compostos identificados por DRX na amostra RSG 5, após tratamentos térmicos............................................................................ 103

TABELA 21 - Principais razões para a utilização dos RSGs na composição vítrea................... 105

TABELA 22 - Resultado dos elementos detectados no líquido recolhido durante a obtenção de frita com incorporação de RSG 2, por FRX............................................... 107

TABELA 23 - Resultado dos elementos detectados no líquido recolhido durante a obtenção de frita com incorporação de RSG 5, por ICP-AES............................................ 109

TABELA 24 - Comparação dos teores dos óxidos antes e após a obtenção dos materiais vítreos. 


\section{LISTA DE FIGURAS}

FIGURA 1 - Produto industrial com alto potencial poluidor e total, Brasil, 1981-1999. Fonte: IBGE.

FIGURA 2 - Tratamento e disposição final de resíduos industriais perigosos (Classe I) no Estado de São Paulo (1996). Fonte: CETESB. Inventário de resíduos industriais $-1996$.

FIGURA 3 - Maiores geradores de resíduos industriais perigosos (Classe I) no Estado de São Paulo (1996). Fonte: CETESB. Inventário de resíduos industriais - 1996..... 24

FIGURA 4 - As MPEs e as MGEs na economia. Fonte: SEBRAE-SP.................................... 44

FIGURA 5 - Taxa de mortalidade das MPEs paulistas. Fonte: SEBRAE-SP .......................... 45

FIGURA 6 - Motivos de mortalidade das MPEs. Fonte: SEBRAE-SP................................... 45

FIGURA 7 - Localização das empresas de galvanoplastia visitadas na zona leste da cidade

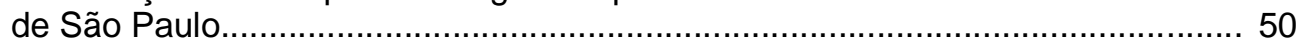

FIGURA 8 - Diagrama de fases do sistema $\mathrm{Na}_{2} \mathrm{O}: \mathrm{CaO}: \mathrm{SiO}_{2}$, indicando as composições

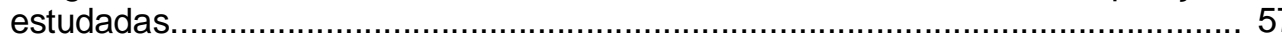

FIGURA 9 - Distribuição da porcentagem de empresas de acordo com a quantidade de lodo

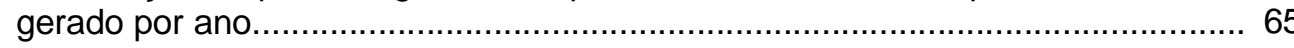

FIGURA 10 - Porcentagem de micro, pequenas e médias empresas (MPMEs) visitadas......... 66

FIGURA 11 - Distribuição do número de empresas de acordo com as atividades exercidas.... 67

FIGURA 12 - Distribuição do número de empresas de acordo com o substrato utilizado.......... 68

FIGURA 13 - Distribuição do número de empresas de acordo com a quantidade ou massa de peças revestidas por mês: a) de acordo com a quantidade e b) de acordo com a

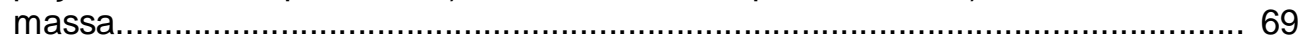

FIGURA 14 - Distribuição do número de empresas de acordo com o índice de retrabalho....... 69

FIGURA 15 - Distribuição do número de empresas de acordo com as destinações dos RSGs.. 70

FIGURA 16 - Distribuição do número de empresas de acordo com o destino final dos RSGs.. 70

FIGURA 17 - Distribuição do número de empresas de acordo com as empresas de coleta dos

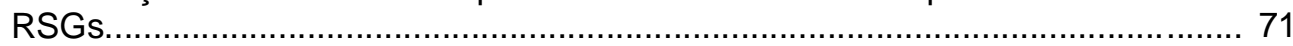

FIGURA 18 - Acondicionamento de lodo em tambor, sem plástico......................................... 72

FIGURA 19 - Acondicionamento de lodo em sacos plásticos, fora de tambor............................ 72

FIGURA 20 - Leito de secagem em condições precárias......................................................... 73

FIGURA 21 - Acondicionamento de lodo em tambor, com saco plástico, porém, sem rotulagem nas paredes externas (não visível).................................................... 73

FIGURA 22 - Distribuição do número de empresas de acordo com o acondicionamento do

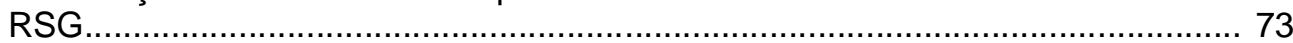

FIGURA 23 - Distribuição do número de empresas de acordo com o tipo de secagem do

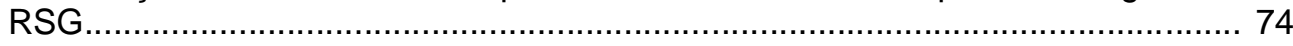

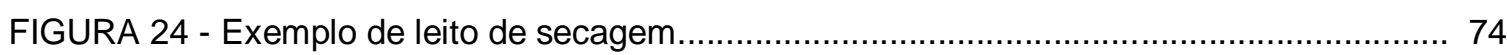

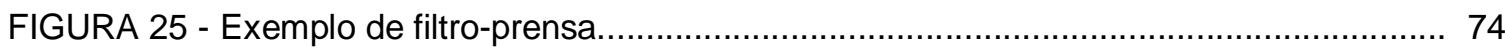


FIGURA 26 - Distribuição da porcentagem de empresas de acordo com o custo pago para a destinação do lodo................................................................................... 76

FIGURA 27 - Resultado de ATD/ATG obtido para a amostra RSG 1 (temperatura até $1400^{\circ} \mathrm{C}$, taxa de aquecimento de $10^{\circ} \mathrm{C} / \mathrm{min}$ e atmosfera de ar sintético).....

FIGURA 28 - Difratogramas obtidos para a amostra RSG 1, após tratamento em diferentes temperaturas (tubo de cobre).

FIGURA 29 - Micrografias obtidas para a amostra RSG 1 tratada a: a) T amb.; b) $110^{\circ} \mathrm{C}$; c) $600^{\circ} \mathrm{C}$ e d) $900^{\circ} \mathrm{C}$

FIGURA 30 - Micrografia obtida para a amostra RSG 1 tratada a $1400^{\circ} \mathrm{C}$ e microanálise química do composto 1

FIGURA 31 - Resultado de ATD/ATG obtido para a amostra RSG 2 (temperatura até $1400^{\circ} \mathrm{C}$, taxa de aquecimento de $10^{\circ} \mathrm{C} / \mathrm{min}$ e atmosfera de ar sintético).

FIGURA 32 - Difratogramas obtidos para a amostra RSG 2, após tratamento em diferentes temperaturas (tubo de cobre)

FIGURA 33 - Micrografias obtidas para a amostra RSG 2 tratada a: a) $\mathrm{T}$ amb.; b) $110^{\circ} \mathrm{C}$; c) $600^{\circ} \mathrm{C}$ e d) $900^{\circ} \mathrm{C}$

FIGURA 34 - Micrografia obtida para a amostra RSG 2 tratada a $900^{\circ} \mathrm{C}$ e microanálise química do composto 1.

FIGURA 35 - Micrografia obtida para a amostra RSG 2 tratada a $900^{\circ} \mathrm{C}$ e microanálise química do composto 2 .

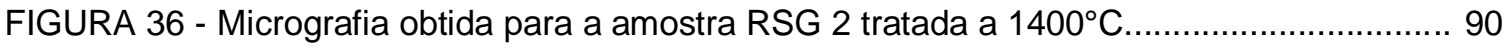

FIGURA 37 - Resultado de ATD/ATG obtido para a amostra RSG 3 (temperatura até $1400^{\circ} \mathrm{C}$, taxa de aquecimento de $10^{\circ} \mathrm{C} / \mathrm{min}$ e atmosfera de ar sintético).....

FIGURA 38 - Difratogramas obtidos para a amostra RSG 3, após tratamento em diferentes temperaturas (tubo de cobre)

FIGURA 39 - Micrografias obtidas para a amostra RSG 3 tratada a: a) T amb.; b) $110^{\circ} \mathrm{C} \mathrm{e}$ c) $600^{\circ} \mathrm{C}$

FIGURA 40 - Micrografia obtida para a amostra RSG 3 tratada a $900^{\circ} \mathrm{C}$ e microanálise

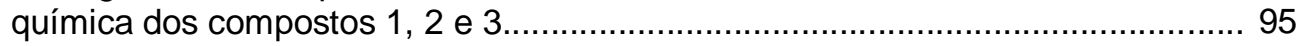

FIGURA 41 - Micrografia obtida para a amostra RSG 3 tratada a $1400^{\circ} \mathrm{C} \ldots \ldots \ldots \ldots \ldots \ldots \ldots \ldots . . . . . . . . . . . . . . . . .95$

FIGURA 42 - Micrografia obtida para a amostra RSG 3 tratada a $1400^{\circ} \mathrm{C}$ e microanálise química dos compostos 1, 2, 3 e 4 .

FIGURA 43 - Resultado de ATD/ATG obtido para a amostra RSG 4 (temperatura até $1400^{\circ} \mathrm{C}$, taxa de aquecimento de $10^{\circ} \mathrm{C} / \mathrm{min}$ e atmosfera de ar sintético).....

FIGURA 44 - Difratogramas obtidos para a amostra RSG 4, após tratamento em diferentes temperaturas (tubo de cobre).

FIGURA 45 - Micrografias obtidas para a amostra RSG 4 tratada a: a) T amb.; b) $110^{\circ} \mathrm{C}$; c) $600^{\circ} \mathrm{C}$ e d) $900^{\circ} \mathrm{C}$

FIGURA 46 - Micrografia obtida para a amostra RSG 4 tratada a $900^{\circ} \mathrm{C}$ e microanálise química dos compostos 1,2 e 3 .

FIGURA 47 - Micrografia obtida para a amostra RSG 4 tratada a $1400^{\circ} \mathrm{C}$... 100

FIGURA 48 - Micrografia obtida para a amostra RSG 4 tratada a $1400^{\circ} \mathrm{C}$ e microanálise química dos compostos 1, 2, 3 e 4 
FIGURA 49 - Resultado de ATD/ATG obtido para a amostra RSG 5 (temperatura até $1400^{\circ} \mathrm{C}$, taxa de aquecimento de $10^{\circ} \mathrm{C} / \mathrm{min}$ e atmosfera de ar sintético).

FIGURA 50 - Difratogramas obtidos para a amostra RSG 5, após tratamento em diferentes temperaturas (tubo de cobre)

FIGURA 51 - Micrografias obtidas para a amostra RSG 5 tratada a: a) T amb. e b) $110^{\circ} \mathrm{C} \ldots \ldots . .104$

FIGURA 52 - Micrografia obtida para a amostra RSG 5 tratada a $600^{\circ} \mathrm{C}$

FIGURA 53 - Micrografia obtida para a amostra RSG 5 tratada a $900^{\circ} \mathrm{C}$ e microanálise química dos compostos 1, 2 e 3..................................................................... 104

FIGURA 54 - Micrografia obtida para a amostra RSG 5 tratada a $1400^{\circ} \mathrm{C}$.

FIGURA 55 - Retirada de material fundido do forno para obtenção de frita com incorporação de RSG 2 (F 27R2 29N 6C): a) Abertura do forno e b) Vertimento em água........ 106

FIGURA 56 - Frita obtida com incorporação de RSG 2 (F 27R2 29N 6C)............................. 106

FIGURA 57 - Vidro obtido com incorporação de RSG 2 (V 20R2 29N 11C)........................... 107

FIGURA 58 - Formação de frita com incorporação de RSG 5: a) Frita obtida (F 24R5 27N 0,5C) e b) Líquido incolor recolhido após vertimento..................... 108

FIGURA 59 - Ensaio qualitativo para verificar presença de cromo. À esquerda: tubo de ensaio com solução padrão contendo cromo e à direita: tubo de ensaio com a amostra. 109

FIGURA 60 - Obtenção de vidro com incorporação de RSG 4: a) Início de vertimento do material fundido em molde de aço pré aquecido a $500^{\circ} \mathrm{C}$ e b) Solidificação do vidro devido à alta viscosidade

FIGURA 61 - Vidro obtido com incorporação de RSG 4 (V 21R4 21N 5C).

FIGURA 62 - Obtenção de produtos vítreos coloridos: a) Frita azulada (F 27R2 29N 6C); b) Vidro azulado (V 21R4 21N 5C); c) Vidro preto (V 20R2 29N 11C) e d) Frita preta (F 24R5 27N 0,5C). 


\section{LISTA DAS PRINCIPAIS ABREVIATURAS}

ETE - Estação de Tratamento de Efluentes

MGEs - Médias e Grandes Empresas

MPEs - Micro e Pequenas Empresas

MPMEs - Micro, Pequenas e Médias empresas

PRUMO/TS - Projeto de Unidades Móveis do Setor de Tratamento de Superfícies, do IPT

RSGs - Resíduos Sólidos Galvânicos

Z.L. - Zona Leste (da cidade de São Paulo) 


\section{INTRODUÇÃO}

A poluição ambiental, a cada dia que passa, torna-se mais crítica, devido às consequências prejudiciais da ação do ser humano. A situação é ainda mais preocupante nas regiões densamente povoadas, como a cidade de São Paulo, com uma concentração de mais de sete mil habitantes por quilômetro quadrado.

A elevada população presente na cidade de São Paulo é causada, dentre outros motivos, pela oportunidade de emprego gerada pelas indústrias. $E$, entre as atividades industriais desenvolvidas nas regiões densamente povoadas, a empresa de galvanoplastia desperta preocupante atenção pelo potencial de risco ambiental.

Particularmente, na zona leste do município de São Paulo, que se destaca como a região mais densamente povoada, com aproximadamente 11.000 habitantes por quilômetro quadrado, há um pólo de empresas de galvanoplastia. Este pólo, centrado predominantemente no setor de cromação, utiliza substâncias consideradas perigosas para o meio ambiente e para a saúde humana, como metais pesados, cromo hexavalente e cianeto.

A galvanoplastia é um processo eletroquímico de deposição de uma fina camada metálica sobre uma superfície, da ordem de micrômetros, para proporcionar proteção contra a corrosão e melhorar o aspecto estético.

Os resíduos sólidos gerados neste processo concentram as substâncias tóxicas mencionadas acima, sendo, desta forma, agressivos ao meio ambiente e ao ser humano se descartado ou armazenado sem devidas precauções. Por outro lado, estes resíduos sólidos apresentam potencial econômico que justifica o reuso ou reaproveitamento funcional de seus componentes.

Neste sentido, este estudo visa abordar aspectos que mitigam a disposição de tais resíduos em regiões onde a exposição de grande massa populacional ao crescente risco ambiental é inevitável. 


\section{OBJETIVO}

Este trabalho propõe obter um panorama socioeconômico e ambiental das empresas de galvanoplastia da zona leste do município de São Paulo, em relação aos seus passivos ambientais (resíduos sólidos armazenados) e oferecer uma opção tecnológica para a valorização de tais resíduos, por meio da incorporação dos constituintes funcionais em matrizes vítreas, com o objetivo de mitigar os componentes nocivos à saúde humana e ao meio ambiente. 


\section{ASPECTOS RELEVANTES DA LITERATURA}

\subsection{Questões ambientais}

Segundo a projeção do grupo de pesquisa Population Reference Bureau $^{1}$, a população mundial atingirá sete bilhões de habitantes neste ano de 2011, sem sinais de estabilização, apesar da redução no ritmo de crescimento em relação às previsões feitas há alguns anos. Este fato representa um crescimento de um bilhão nos últimos 12 anos, acarretando pressões pela busca por alimentos, infraestrutura e serviços essenciais, como educação e saneamento. Ao mesmo tempo que políticas mundiais tentam atender a estas demandas, encontram grandes dificuldades para reverter e minimizar os danos ao meio ambiente e diminuir as desigualdades econômicas e sociais ${ }^{2}$.

Historicamente, no Brasil, desde a campanha do "Invista neste País" dos anos setenta, que indiretamente indicava "venha nos poluir", uma vez que pela ausência de ações restritivas efetivas atraía indústrias poluentes dos países desenvolvidos, são vários os exemplos que ilustram a despreocupação do setor industrial brasileiro com a questão ambiental. De todos os eventos ambientalmente catastróficos, o que despertou críticas mais exaltadas foi a prolongada contaminação do entorno do distrito industrial de Cubatão, no Estado de São Paulo (SP). Nesta região, constatou-se que, nos anos oitenta, 320 fontes de emissão ${ }^{a}$ (relacionadas a 116 unidades industriais), chegaram a emitir cerca de 400.000 toneladas anuais de poluentes diversos. As consequências para a saúde humana foram dramáticas, as quais cada pessoa recebia 12 quilos de compostos venenosos e cancerígenos a cada dia, $18 \%$ da população sofria de doenças respiratórias e registravam-se os mais altos índices de anencefalia (crianças nascidas sem cérebro) do hemisfério (um caso para cada 250 nascimentos) $)^{3}$.

Apesar da recente tomada de consciência nacional com as questões ambientais, ainda se tem uma ausência de dados estatísticos sobre emissões de poluentes, a qual dificulta análise sistemática do desempenho ambiental das indústrias em geral. Entretanto, é possível avaliar a expansão dos setores de maior potencial poluidor em relação ao restante da indústria, utilizando-se alguns

\footnotetext{
${ }^{a}$ É importante distinguir emissões industriais de poluição industrial. As emissões são os resíduos da atividade industrial, que são em parte absorvidas pelo meio ambiente. Quando a capacidade assimilativa do meio ambiente é inferior à quantidade de emissões surge, então, a poluição.
} 
indicadores especialmente pontuados pelo Departamento de Indústria do Instituto Brasileiro de Geografia e Estatística (IBGE) ${ }^{3}$. Na FIG. 1, são ilustrados os dados relacionados com as duas penúltimas décadas (1981-1999), mostrando comparativamente o crescimento das indústrias e, em especial, as de alto potencial poluidor. Nota-se nitidamente um maior crescimento das indústrias que mais poluem em relação à média geral da indústria.
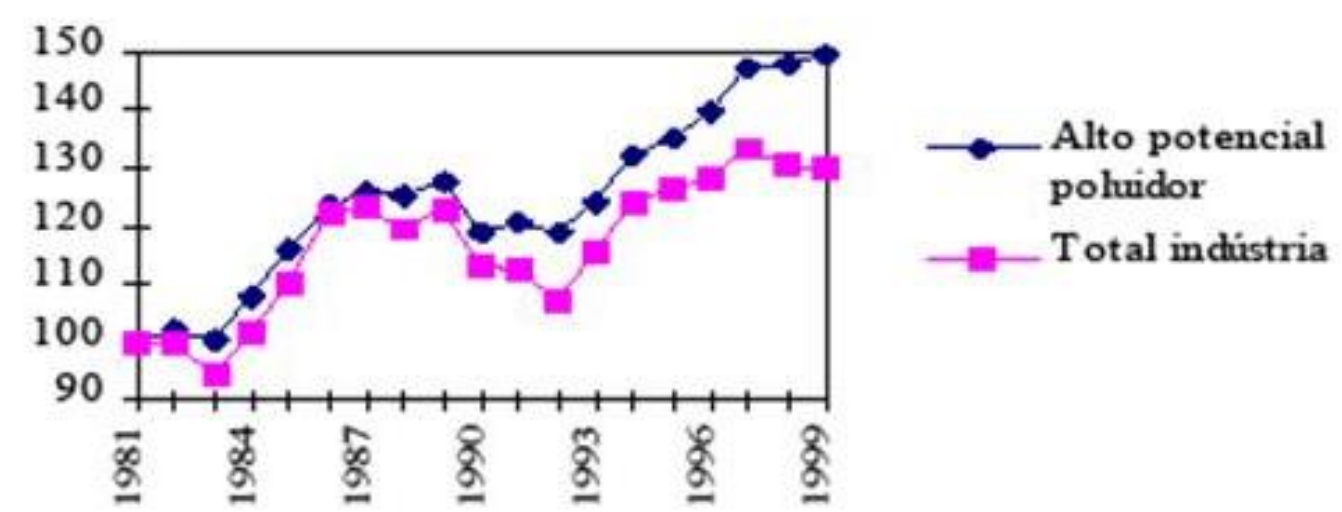

FIGURA 1 - Produto industrial com alto potencial poluidor e total, Brasil, 1981-1999. Fonte: IBGE ${ }^{3}$

Várias razões podem ser mencionadas para explicar este fato e, dentre elas, três merecem destaque:

1) o atraso no estabelecimento de normas ambientais e agências especializadas no controle da poluição industrial demonstra que, de fato, a questão ambiental não estava entre as prioridades da política pública. Apenas na segunda metade dos anos setenta é que foi criado o primeiro órgão especificamente para este fim (Fundação Estadual de Engenharia do Meio Ambiente FEEMA/RJ), sendo que as atividades que emitiam poluentes já ocorriam há décadas;

2) o anseio pelo crescimento da economia do país com a industrialização, privilegiou os setores que mais poluíam. Embora o Brasil tenha construído uma base industrial diversificada, o avanço da economia esteve calcado no uso indireto de recursos naturais (energia e matérias-primas de baixo custo), ao invés de expandir-se pela geração ou absorção de tecnologias com base no crescimento responsável, como em muitos países. Após a consolidação dos investimentos do II Plano Nacional de Desenvolvimento - II PND (19741979), este quadro acentuou, devido à expansão do número de indústrias de grande potencial poluidor, sem o devido acompanhamento de tratamento 
destas emissões. Entre estas, destacam-se as pertencentes aos complexos metalúrgico e químico/petroquímico;

3) as facilidades de mercado encontradas pelas empresas exportadoras em comercializar produtos manufaturados também foi um fator que contribuiu para o aumento de atividades industriais poluidoras. Alguns estudos empíricos mostram que as empresas exportadoras emitem mais poluentes que a média da indústria brasileira.

Estes fatos ainda são verificados atualmente no Brasil e observa-se que os países desenvolvidos migram seus investimentos industriais de alto risco ambiental para países com legislação mais branda (ou mesmo inexistente), com o objetivo de evitar o aumento nos custos de produção impostos por controles ambientais mais rigorosos. A transferência de capitais leva a uma redistribuição da renda mundial em favor daqueles que estão dispostos a poluir mais em troca de maior crescimento econômico a curto prazo. Assim, a migração de indústrias poluentes para os países em desenvolvimento contribui para a manutenção média do bem estar mundial. Desta forma, os países desenvolvidos aceitam perdas econômicas para obter um meio ambiente mais saudável, enquanto que os países em desenvolvimento aceitam ter seu ambiente poluído em troca do crescimento econômico ${ }^{3}$.

A partir desta análise, conclui-se que a qualidade ambiental torna-se um "bem de luxo". Os mais afetados por danos ambientais são, em geral, as classes e regiões mais desfavorecidas, que têm menor poder político e econômico e, portanto, menor chance de exigir uma vida mais saudável. As indústrias que mais emitem resíduos não distribuem de forma socialmente equitativa a renda gerada em sua produção. Além disto, problemas ambientais podem trazer perdas econômicas, como queda da produtividade da mão de obra e gastos associados à deterioração da saúde da população ${ }^{3}$.

No Brasil, muitas vezes prevalece a ideia de que o controle ambiental pode ser uma barreira ao desenvolvimento industrial, ignorando seu potencial para a geração de progresso tecnológico. Esta visão vem sendo alterada nos últimos anos e nota-se que as empresas inovadoras são também as que mais consideram o meio ambiente como fonte de competitividade. Tais empresas geralmente adotam sistemas de qualidade definidos, como as séries ISO 9.000 e ISO $14.000^{4}$, que se preocupam com a organização empresarial e com o meio 
ambiente. Estas normas permitem às empresas demonstrar 0 seu comprometimento com o desenvolvimento sustentável. A série ISO $14.000^{4}$ normaliza o gerenciamento ambiental de forma eficaz, estabelecendo e mantendo procedimentos para a identificação, exame e avaliação de efeitos ambientais quanto à poluição. Ter uma estratégia ambiental responsável é estabelecer critérios para minimizar o impacto das atividades ao meio ambiente, como, por exemplo, redução do uso de matéria-prima e do consumo de energia. Assim, ocorre uma melhora na eficiência dos processos e redução da geração de resíduos, que também pode ser alcançada pela reutilização dos mesmos.

Embora os processos químicos de produção inevitavelmente gerem resíduos, atualmente, muitos destes procedimentos vêm sendo redirecionados para reduzir ou eliminar o uso ou a geração de substâncias nocivas à saúde humana e ao ambiente. Estas práticas são classificadas como "Química Verde" (Green Chemistry), "Química Limpa” (Clean Chemistry), Química Ambientalmente Benigna (Environmentally Benign Chemistry) ou ainda "Química Autossustentável" (Self Sustainable Chemistry) $^{5,6}$.

O termo Green Chemistry (Química Verde) surgiu em 1993 com a expansão do programa Alternative Synthetic Pathways for Pollution Prevention criado pela Agência de Proteção Ambiental Norte Americana (EPA), em 1991. O objetivo inicial deste projeto foi aprimorar os produtos químicos existentes ou desenvolver produtos novos menos perigosos para a saúde humana e para o meio ambiente. Esta proposta recebeu incentivos do meio acadêmico, das indústrias e de agências governamentais e não governamentais ${ }^{7}$. A implementação da "Química Verde" pode ser baseada em doze princípios ${ }^{8}$, que objetivam o desenvolvimento de procedimentos que empreguem mínima quantidade de reagentes e que não produzam resíduos tóxicos. Para tanto, os reagentes empregados devem possuir mínima toxicidade e os resíduos devem ser reciclados e, se possível, reutilizados, caso contrário, os procedimentos devem incluir uma etapa de tratamento dos resíduos gerados ${ }^{9}$. Quando indústrias implementam tecnologias para eliminar substâncias perigosas de seus produtos e processos, significativos benefícios ambientais e incentivos econômicos são alcançados.

Neste sentido, também pode ser citado o conceito de Produção mais Limpa $(P+L)^{10}$, adotado pela Companhia de Tecnologia de Saneamento Ambiental 
do Estado de São Paulo (CETESB). Este conceito pode ser resumido como um conjunto de estratégias, práticas e condutas econômicas, ambientais e técnicas, para evitar ou reduzir a emissão de poluentes no meio ambiente por meio de ações preventivas, ou seja, evitando a geração de poluentes ou criando alternativas para que estes sejam reutilizados ou reciclados.

No entanto, mesmo com o avanço dos últimos anos, as aplicações das ações disponíveis ainda contribuem pouco para um meio ambiente saudável. É ideal que muitos outros estudos e, principalmente, novas ações sejam realizadas, para que o Brasil deixe de ser poluidor e passe a ser um país emergente "limpo".

\subsection{Resíduos sólidos}

O crescimento populacional e das atividades industriais tem acarretado um aumento considerável na produção de resíduos sólidos. Desta forma, anseiase por um gerenciamento criterioso destes resíduos, de modo a permitir o controle e a prevenção da poluição do meio ambiente. Segundo a CETESB, os resíduos sólidos podem ser divididos em duas grandes áreas: a) os resíduos urbanos e de serviços de saúde e b) os resíduos industriais ${ }^{11}$.

Considerando-se que neste trabalho serão focados os resíduos industriais, estes são classificados em função de suas propriedades físicoquímicas, químicas ou infectocontagiosas e com base na presença e quantidade limite de contaminantes presentes em sua massa. A norma ABNT NBR 10004:2004 ${ }^{12}$ apresenta três classificações para os resíduos industriais:

Resíduos classe I - perigosos;

Resíduos classe lla - não inertes;

Resíduos classe llb - inertes.

São considerados perigosos os resíduos que apresentam riscos à saúde pública e ao meio ambiente, devido às características de inflamabilidade, corrosividade, reatividade, toxicidade e patogenicidade. São considerados não inertes os resíduos biodegradáveis e combustíveis. São considerados inertes os resíduos que podem ficar na água por sete dias, deixando-a ainda potável ${ }^{12}$.

As normas ABNT NBR 10.005:2004 ${ }^{13}$, ABNT NBR 10.006:2004 ${ }^{14} \mathrm{e}$ ABNT NBR $10.007: 2004^{15}$ tratam sobre procedimentos padronizados para a 
obtenção do extrato lixiviado, do extrato solubilizado e para a amostragem de resíduos, respectivamente.

Um levantamento de dados de 1996, realizado pela CETESB $^{\mathrm{b}}$, assinala que as indústrias do Estado de São Paulo geraram, por ano, mais de 500 mil toneladas de resíduos sólidos perigosos (Classe I), cerca de 20 milhões de toneladas de resíduos sólidos não inertes e acima de um milhão de toneladas de resíduos inertes. Os levantamentos revelam, ainda, que 53\% dos resíduos perigosos são tratados, $31 \%$ são armazenados e os $16 \%$ restantes são depositados no solo (FIG. 2) ${ }^{16}$.

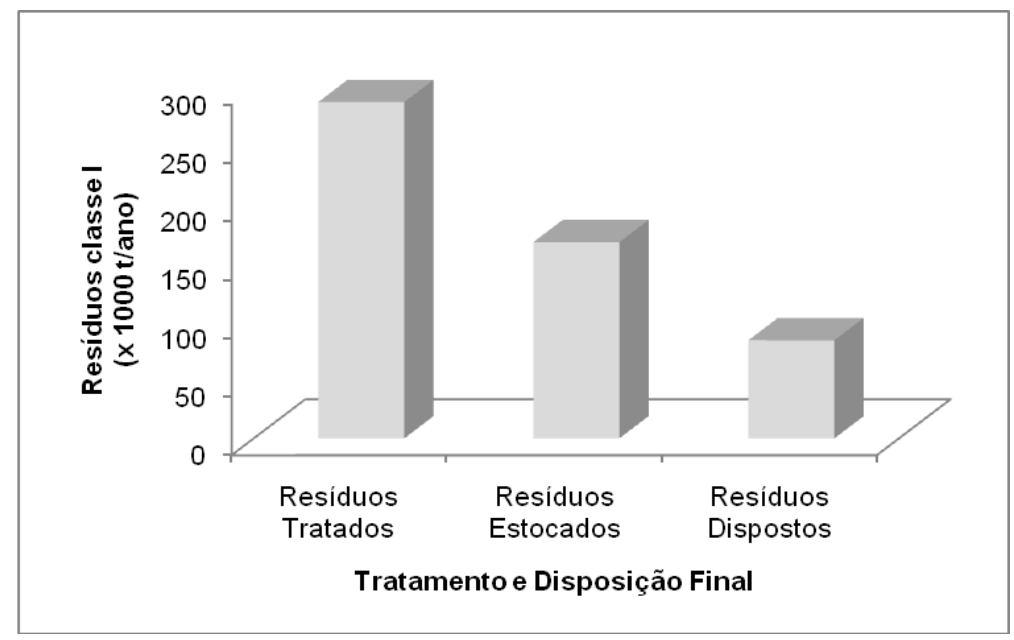

FIGURA 2 - Tratamento e disposição final de resíduos industriais perigosos (Classe I) no Estado de São Paulo (1996). Fonte: CETESB. Inventário de resíduos industriais - 1996

Na FIG. 3, tem-se os dados referentes à geração de resíduos sólidos Classe I em função da categoria industrial. Verifica-se nesta figura que os maiores geradores de resíduos perigosos são as indústrias químicas, seguidos da de material de transporte, de couros e peles e de metalurgia, sendo responsáveis por quase $90 \%$ do total de resíduos gerados ${ }^{16}$. Os geradores de resíduos sólidos

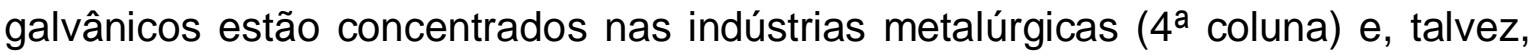
em parte, no setor de indústrias químicas (1ª coluna). Não há dados consensuais em relação à quantidade de lodos galvânicos gerados. As fontes encontradas mencionam valores diferentes, porém, deve-se considerar que foram publicadas em épocas diferentes. Uma delas, por exemplo, cita que são gerados cerca de 50.000 toneladas por ano no Estado de São Paulo (1998) ${ }^{17}$ e outra, que são gerados cerca de 150.000 a 200.000 toneladas por ano no Estado de São Paulo

\footnotetext{
${ }^{\mathrm{b}}$ Segundo informações da CETESB, outro inventário de resíduos sólidos foi realizado nos últimos anos, porém, os dados ainda não estão disponíveis.
} 
$(2007)^{18}$. Apesar dos dados serem estimados, é possível que tenha ocorrido um aumento significativo na quantidade de resíduos sólidos de galvanoplastia até 2007, com o crescimento da atividade industrial neste setor.

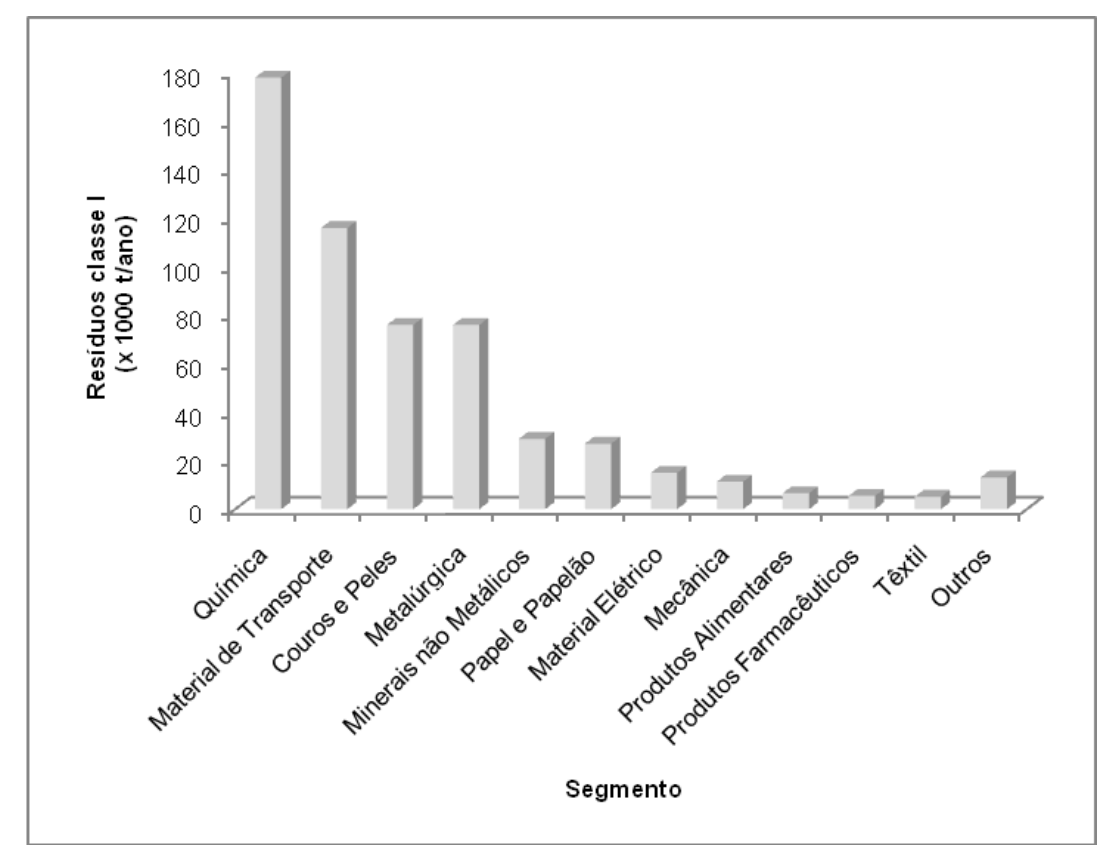

FIGURA 3 - Maiores geradores de resíduos industriais perigosos (Classe I) no Estado de São Paulo (1996). Fonte: CETESB. Inventário de resíduos industriais - 1996

\subsubsection{Tipos de tratamento dos resíduos sólidos galvânicos}

Para os resíduos sólidos de galvanoplastia, os tratamentos mais utilizados são: "estocagem", disposição em aterros, incineração, coprocessamento, plasma térmico, microencapsulação e reciclagem. Todas, no entanto, apresentam vantagens e desvantagens que devem ser consideradas.

- Estocagem: a estocagem de resíduos, embora não seja uma forma de tratamento propriamente dita, é uma prática que leva a um constante crescimento do passivo ambiental da empresa. Todavia, é admitida desde que sejam observadas as normas brasileiras para o procedimento, que preveem infraestrutura especial com sistemas de segurança e monitoramento contínuo. A grande totalidade dos resíduos formados por lodos contém água em excesso, sendo assim, o acondicionamento deve ser muito cuidadoso e pode vir a ocupar grandes áreas ${ }^{19}$.

- Aterramento: atualmente, aterro industrial é a destinação mais econômica para os resíduos industriais perigosos, mas na realidade não se apresenta como solução definitiva. Nos EUA e na Europa os aterros são vistos com restrições, por não serem caracterizados como formas de tratamento. Após acidentes com 
resíduos químicos como o de "Love Chanel", nos EUA, as ações de controle se intensificaram. Segundo este processo, o resíduo deve permanecer soterrado por tempo indeterminado e não se sabe como se comportará ao longo dos anos. O aterro industrial parte da premissa de condições hidrológicas muito boas e de excelente projeto e concepção, sendo tais locais escassos. $O$ processo envolve, em alguns casos, um pré-tratamento dos resíduos sólidos por estabilização, solidificação, neutralização e encapsulamento, além do tratamento dos gases e do líquido (chorume), após drenagem ${ }^{20}$. Nos países europeus, empresas que fizeram opção por este sistema no passado, hoje estão envolvidas em processos judiciais que as obrigam a fazer a custosa recuperação total das áreas de deposição e dos lençóis freáticos ${ }^{17,21}$.

- Incineração: a incineração é outra alternativa adotada comumente pela indústria química, sendo um recurso para a destruição térmica dos resíduos. É o processo que hoje enfrenta menor resistência ou restrição por parte dos órgãos de controle. Os incineradores possuem os sistemas de controle exigidos por lei para compostos perigosos e permitem a queima de resíduos líquidos ou sólidos, porém, são inviabilizados sob o ponto de vista financeiro. Este sistema pode parecer vantajoso para os lodos galvânicos devido à redução de seu volume, mas deixa, porém, por resolver a questão da disposição final das cinzas, que ainda apresentam alto grau de toxidade e, em alguns casos, a contaminação da atmosfera ${ }^{22}$. Como parte do processo, são necessários equipamentos de limpeza de gases, tais como precipitadores ciclônicos de partículas, precipitadores eletrostáticos, lavadores de gases e outros, mas, ainda assim, é gerado dióxido de carbono, agente causador do efeito estufa, além de outros poluentes. As cinzas normalmente são devolvidas ao gerador de resíduos para serem estocadas ou dispostas em aterros de classe I. O único incinerador da cidade de São Paulo foi fechado devido ao crescimento da população ao redor e as constantes reclamações pelas intensas emissões. Atualmente, algumas empresas de soluções ambientais recusam incinerar os resíduos sólidos galvânicos, devido à enorme quantidade de metais pesados, que ficam alojados nas cinzas, preferindo encaminhar diretamente para o aterro classe I ou oferecer outra solução, caso possuam. Os incineradores são mais apropriados para a decomposição de compostos orgânicos ${ }^{23}$. 
- Coprocessamento: o coprocessamento é a destruição térmica de resíduos em fornos industriais, principalmente, em fornos de cimento. Seu diferencial em relação às demais técnicas de queima está no aproveitamento do resíduo como potencial energético ou substituto de matéria-prima na indústria cimenteira. Neste processo também é necessário tratar os gases. O fator agravante está na falta de confirmação em bases científicas, que o cimento seja capaz de reter eternamente o resíduo sem liberar o poluente ${ }^{24}$.

- Plasma térmico: o plasma térmico também promove a destruição térmica dos resíduos sólidos, porém, utilizando um gás ionizante. A tocha de plasma é um dispositivo que transforma energia elétrica em calor, transportado por um gás. As temperaturas de operação podem variar de $1.500^{\circ} \mathrm{C}$ a $50.000^{\circ} \mathrm{C}$, volatilizando a matéria orgânica e fundindo os materiais inorgânicos, gerando, no final, uma matriz vítrea, contendo todo o material tóxico inertizado. A matriz vítrea pode ser utilizada como agregado na construção civil ou como matériaprima para as indústrias siderúrgica e cerâmica. Esta tecnologia pode ser utilizada para diversos fins, como: decomposição de resíduos, recobrimento físico e químico, síntese de pós finos, densificação de refratários e outros. No Japão é utilizado para fundir cinzas de incineração e nos EUA é utilizado para recuperar metais de catalisadores. Também é necessária a utilização de um lavador de gases. A desvantagem está no alto consumo de energia, o que acarreta maior custo ${ }^{25}$.

- Microencapsulação: a microencapsulação do resíduo proporciona como produto final um sólido monolítico com integridade estrutural suficiente para limitar a migração dos contaminantes. Este processo pode ser utilizado para o tratamento de metais pesados, sulfetos, cianetos, cloretos, orgânicos e outros tipos de lodos. Os processos de estabilização, inertização e solidificação compõem a microencapsulação. Este processo obteve resultados positivos na cidade de Shroeder, em Santa Catarina, onde foram produzidos tijolos e lajes de calçamento contendo metais tóxicos (notadamente $\mathrm{Cu}$ e $\mathrm{Zn}$ ), quimicamente tratados e encapsulados em cimento. A maior desvantagem do microencapsulamento se relaciona com a sua complexidade, com os custos elevados e, também, com as dúvidas quanto ao fato do cimento ser uma matriz estável e adequada a longo prazo. De qualquer forma, a microencapsulação é 
uma tendência promissora tanto na Europa quanto nos EUA e pode se disseminar no Brasil ${ }^{17}$.

- Reciclagem: a reciclagem através da recuperação de materiais contidos no resíduo, que possuam algum valor econômico, pode ser viável dependendo do material e da sua concentração. Porém, nos resíduos galvânicos, um ou mais componente perigoso pode eventualmente apresentar potencial de reciclagem, mas não todos, de modo que este processo oferece uma solução apenas parcial para este tipo de material. A reciclagem, embora se apresentando como uma das ações mais positivas para o setor de tratamento de superfícies, não contribui decisivamente para a eliminação do resíduo já estocado ou gerado ${ }^{19}$.

\subsubsection{Inertização/estabilização de resíduos sólidos galvânicos}

O lodo proveniente do tratamento de efluentes do processo de galvanoplastia tem recebido particular atenção devido à natureza de sua constituição baseada em metais alcalinos e de transição, principalmente cromo, níquel, cobre, zinco e ferro. O descarte ou estocagem inadequada deste resíduo pode causar danos ao meio ambiente e à saúde ${ }^{26}$. Procedimentos empregando meios físico-químicos, como rotas hidrometalúrgicas, seriam uma alternativa para tratamento dos resíduos. Entretanto, a elevada heterogeneidade do lodo das indústrias, faz com que se torne inviável a utilização desta técnica ${ }^{27}$. Algumas alternativas vêm sendo estudadas nos últimos anos para reutilização destes resíduos promovendo a inertização/estabilização, que tem como objetivo imobilizar os elementos contaminantes em matrizes estáveis ${ }^{28}$.

A incorporação de alguns resíduos industriais em matrizes cerâmicas tem sido estudada como uma efetiva técnica de baixo custo para fixação de espécies metálicas em produtos utilizáveis ou como uma tentativa de reduzir o volume de resíduos no ambiente. Magalhães et al. ${ }^{28}$ estudaram o efeito de alguns parâmetros do processo de inertização em cerâmica vermelha pelo mecanismo de macroencapsulação, como tempo de mistura, temperatura, tempo de calcinação, concentração de lodo adicionado, entre outros. Utilizando ferramentas de estatística para definir a relevância de cada variável experimental no processo de inertização, observaram que a temperatura de queima e o grau de aglomeração imposto pela pressão do início da mistura foram os parâmetros mais 
significativos no processo de inertização, além da quantidade de lodo adicionado na mistura.

Luz et al. ${ }^{29}$ estudaram a incorporação dos resíduos galvânicos em cimento de sulfoaluminato de cálcio (CSA). As principais vantagens deste tipo de cimento quando comparado com cimento Portland estão relacionadas ao tempo de preparo, melhores propriedades mecânicas e processo de produção com menor impacto ambiental devido à baixa temperatura de calcinação e baixa emissão de $\mathrm{CO}_{2}$. Considerando que a matriz foi constituída com $77 \%$ em massa de resíduo galvânico e somente $23 \%$ em massa de cimento, foi possível obter valores de dureza da matriz sólida superiores aos especificados para os padrões brasileiros (ABNT NBR 7170:1983) para estruturas de cerâmicas de tijolos.

Silva, A. C. e Mello-Castanho, S. R. H. ${ }^{30}$ propuseram a incorporação de resíduos galvânicos em vidro silicato. O vidro foi utilizado porque apresenta características químicas e físico-químicas desejáveis para a inertização, tais como bom comportamento durante a fusão, homogeneidade, durabilidade e estabilidade em diferentes condições ambientais. Em adição, apresentam estrutura aberta amorfa, que permite incorporar com certa facilidade um grande número de elementos da tabela periódica. Utilizando-se técnicas de ajuste de formulação de composição, verificaram que vidros com alta concentração de resíduos sólidos galvânicos apresentaram características interessantes como alta resistência a ataque hidrolítico, média resistência ao ataque alcalino e baixa resistência a ataque ácido quando comparados com o vidro comum com a mesma composição básica. Vidros com até $40 \%$ em massa de resíduos sólidos galvânicos apresentaram boa resistência química, na qual a completa inertização ou diminuição dos efeitos dos resíduos tóxicos galvânicos prejudiciais à saúde foi obtida.

Milanez et al. ${ }^{26}$ estudaram uma alternativa funcional para a inertização dos resíduos galvânicos incorporando-os como corantes na formulação de pigmentos inorgânicos. A formação do pigmento foi acompanhada por análises de difração de raios $X$, onde foi observada a formação de fases do tipo espinélio, contendo os metais $\mathrm{Fe}, \mathrm{Cr}$ e $\mathrm{Zn}$, indicando que ocorreu a inertização destes metais. Nestes estudos observou-se que foi possível incorporar até $20 \%$ do resíduo de galvanoplastia na produção de pigmentos inorgânicos a base de $\mathrm{Fe}$, 
Cr e $\mathrm{Zn}$, sem que as características e qualidades fundamentais de tais pigmentos fossem alteradas.

Outros trabalhos têm como objetivo estudar o comportamento dos resíduos sólidos galvânicos em produtos manufaturados, contribuindo, assim, direta ou indiretamente para a preservação da saúde humana e do meio ambiente. Alguns exemplos são os trabalhos que tratam sobre a recuperação de zinco ou outros metais do próprio resíduo galvânico ${ }^{31-36}$, a aplicação de metais em concreto asfáltico ${ }^{37}$, a utilização em matrizes vítreas ${ }^{38-40}$ e em outros materiais cerâmicos $^{41-44}$. Ainda assim, observa-se, de forma acentuada, uma grande carência no setor de galvanoplastia, de soluções pontuais locais, economicamente atrativas, para a destinação do resíduo sólido galvânico. É notória a ausência de métodos na avaliação e destinação com responsabilidade ambiental, sem que sejam estritamente ações realizadas sob a ameaça de atuação dos órgãos reguladores e de controle.

\subsection{Vidros e revestimentos cerâmicos}

O vidro é um material com estrutura amorfa, contendo particularidades que não o definem nem como líquido, nem como sólido cristalino. Suas distribuições atômicas o fazem parecer mais com os líquidos viscosos que com os sólidos cristalinos. Além disto, também não apresenta a temperatura característica de transformação de estado sólido-líquido, que ocorre nos sólidos cristalinos. No entanto, devido às suas propriedades de rigidez, se assemelha aos sólidos. Não apresenta ordem a longas distâncias e, desta forma, não fratura em direções preferenciais. Entretanto, pode fluir sob a ação de uma elevada tensão de cisalhamento, como ocorre nos metais, que são materiais cristalinos ${ }^{45}$.

Em geral, os vidros são classificados de acordo com sua composição química, aplicação e processo de fabricação. Os vidros silicatos são os mais comuns usados para aplicações em janelas, placas, embalagens e bulbos de lâmpadas incandescentes e são classificados em quatro grupos principais: vidro silicato tipo soda-cal; vidro silicato de chumbo; vidro tipo boro-silicato; e vidro tipo alumino-silicato. Diversos elementos químicos são utilizados na estrutura dos vidros para a melhoria de suas propriedades, por exemplo, diminuindo as temperaturas de processamento e melhorando a viscosidade e a resistência química $^{46}$. 
Os óxidos modificadores de rede e, dentre estes, os óxidos alcalinos, podem atuar como fundentes. A finalidade dos fundentes é favorecer o processo de formação do vidro, reduzindo sua temperatura de fusão e facilitando a sua fabricação. O fundente (ou o modificador) mais utilizado na formação do vidro silicato é o óxido de sódio que, em geral, é adicionado ao vidro na forma de carbonato ou hidróxido de sódio. Muitos óxidos metálicos atuam como modificadores $\left(\mathrm{Al}_{2} \mathrm{O}_{3}\right)$, redutores $(\mathrm{ZnO}, \mathrm{NiO})$ e corantes $\left(\mathrm{Fe}_{2} \mathrm{O}_{3}, \mathrm{Cr}_{2} \mathrm{O}_{3}\right)$ e estes cátions, em geral, estão presentes no lodo galvânico ${ }^{46}$.

Revestimentos também podem ser feitos à base de silicatos e outros óxidos e são aplicados sobre produtos metálicos ou cerâmicos. Sua função principal é impermeabilizar a superfície de um corpo cerâmico, de modo a permitir a aplicação de técnicas de decoração e, em alguns casos, aumentar as propriedades tecnológicas, tais como a resistência à abrasão ${ }^{47}$.

Os revestimentos mais comuns são os esmaltes e os vidrados baseados em sistemas de silicatos.

Esmaltes e vidrados são comumente aplicados na forma de suspensões contendo misturas de pós. Os vidrados são usualmente constituídos por fritas pré-fundidas (ex: vidros silicatados) e outras adições (ex: caulins, corantes). Estes componentes são moídos e misturados em moinho de bolas e aplicados por várias técnicas, como imersão, vazamento e jateamento. A queima subsequente do produto resulta em fusão parcial do revestimento e formação de uma camada fina e impermeável, firmemente aderida à base. Como exemplo, pode-se obter pela técnica de jateamento, o revestimento de camadas constituídas por óxidos altamente refratários na forma de pós, utilizando-se queimadores a gás ou por plasma. Neste processo, as partículas previamente fundidas no queimador são aplicadas por jateamento em forma de gotas sobre a superfície do material. Este, que se encontra em temperatura mais baixa, favorece a solidificação das partículas do revestimento. Os recobrimentos refratários podem ser aplicados tanto em materiais metálicos como cerâmicos ${ }^{47}$.

As matérias-primas empregadas para os vidrados são similares às utilizadas na produção de vidros, porém, o grau de pureza requerido é menor. A opacidade e coloração pode ser conferida pela presença de fluoretos, fosfatos, $\mathrm{ZrO}_{2}$ e $\mathrm{TiO}_{2}$. As substâncias mais utilizadas são, por exemplo, $\mathrm{Fe}_{2} \mathrm{O}_{3}$ (marrom avermelhado), $\mathrm{Cr}_{2} \mathrm{O}_{3}$ (verde), CdS (amarelo) e CdS + SdSe (vermelho) ${ }^{47}$. 
Dependendo da composição química, os revestimentos são obtidos a partir dos produtos denominados industrialmente como fritas que, por sua vez, são obtidos por meio do resfriamento rápido da mistura de óxidos em água sob agitação, após a fusão, em temperaturas da ordem de $1000^{\circ} \mathrm{C}$ a $1400^{\circ} \mathrm{C}$. A fusão pode ser realizada em fornos a gás, elétricos ou de indução. Após o resfriamento, as fritas obtidas são moídas até a granulometria desejada ${ }^{47}$.

\subsection{Tratamento de superfícies - galvanoplastia ${ }^{48}$}

Revestir a superfície de um objeto, conferindo-lhe maior resistência à corrosão e melhor aspecto estético, é uma atividade importante para o desenvolvimento industrial, crescimento econômico e geração de novos processos, e vem sendo praticada desde a antiguidade. A galvanoplastia, trabalho realizado pelas indústrias galvânicas, é um processo químico ou eletroquímico de deposição de uma fina camada metálica sobre uma superfície, da ordem de micrômetros.

Em escavações arqueológicas na Itália, foram encontrados vasos decorados com lâminas de chumbo, estatuetas recobertas com cobre e pontas de lança douradas que evidenciam a utilização de revestimento por metais desde 1.000 a. C. No Império Romano, peças de cobre eram recobertas com ouro e prata fundidos.

O desenvolvimento da galvanoplastia está estreitamente ligado à geração e aproveitamento da energia elétrica. A primeira bateria conhecida data de 250 a. C. e foi encontrada em escavações nas proximidades de Bagdá, em meio a objetos dourados e prateados. Tratava-se de um jarro de louça, contendo vinagre ou outra solução eletrolítica, vedado por tampa de resina (asfalto), com uma barra de ferro revestida com cobre que atravessava a tampa e alcançava o seu fundo. Este aparato produzia corrente contínua de aproximadamente 1,1 volt.

A denominação de galvanoplastia está associada ao nome de família do anatomista e médico italiano Luigi Galvani (1737-1798), que observou a contração de músculos de rãs mortas quando em contato com diferentes metais, sem que houvesse aplicação de corrente elétrica externa. Este fato, o levou a concluir que certos tecidos geravam eletricidade por si próprios - eletricidade animal - semelhante à gerada por máquinas ou raios. 
O físico italiano Alessandro Volta (1745-1827), ao repetir os experimentos de Galvani em 1799, percebeu que o tecido muscular da rã, umedecido em solução salina, conduzia corrente entre diferentes metais, o que sugeria que a eletricidade observada por Galvani era produzida pelos objetos de metal que prendiam as pernas da rã. Ao modificar o experimento, o físico descobriu que a eletricidade resultava da reação química entre um fio de cobre e uma barra de ferro em solução salina, não havendo necessidade de um elemento biológico para o fenômeno. Ele produziu, então, uma bateria ao empilhar vários discos de cobre e zinco, separados por discos de papel ou papelão molhados em água salgada, prendendo este conjunto com um arame de cobre. Ao fechar o circuito, a eletricidade fluiu através da pilha, que passou a ser denominada de pilha galvânica ou voltaica. Mesmo rudimentar, a bateria de Volta possibilitou descobertas importantes no campo eletroquímico, inclusive a eletrodeposição.

O desenvolvimento tecnológico galvânico permitiu potencializar o brilho e a cor dos metais nobres, como ouro, entre outros, despertando o interesse do mercado. Na segunda metade do século XIX, com o aumento da atividade industrial, surgiram novas aplicações para o tratamento de superfícies com metais, tanto para efeitos decorativos como para atender requisitos de engenharia, como proteção à corrosão e aumento de resistência mecânica.

No Brasil, o processo galvânico foi iniciado no revestimento de peças para bicicletas, arreios de cavalos, fivelas de cintos, bandejas, bules e ourivesaria, em bases essencialmente estéticas. Com a implantação da indústria automobilística, o desenvolvimento das indústrias galvânicas foi favorecido, incentivando a profissionalização e introduzindo, a partir de 1920, novas tecnologias, normas e requisitos de qualidade.

Em 1934, foi criado o Sindicato de Galvanoplastia e Niquelação do Estado de São Paulo (SIGESP) que, a partir de 1979, passou a se chamar Sindicato da Indústria de Proteção, Tratamento e Transformação de Superfícies do Estado de São Paulo (SINDISUPER). Entre suas atividades, participa de comissões da Associação Brasileira de Normas Técnicas (ABNT) e do Conselho de Não Ferrosos e Siderurgia (CONSIDER).

O SINDISUPER (ainda SIGESP) estimulou a criação, em 1968, da Associação Brasileira de Tecnologia Galvânica (ABTG), hoje Associação 
Brasileira de Tratamento de Superfície (ABTS), que visa o aprimoramento dos profissionais do ramo.

Atualmente, as solicitações cada vez mais rigorosas dos aspectos de qualidade e de normas técnicas, do cumprimento da legislação de segurança e saúde no trabalho, e das leis ambientais, exigem novos investimentos das empresas de galvanoplastia no Brasil para a manutenção da competitividade e o aprimoramento de seus processos em todo o ciclo de fabricação e revenda de seus produtos.

\subsubsection{Galvanoplastia no Brasil e no Estado de São Paulo}

Segundo a Relação Anual de Informações Sociais (RAIS/2005), as empresas de galvanoplastia são denominadas de galvanotécnica e folheados. A indústria de folheados foi mencionada de forma separada, talvez, por sua expressividade, uma vez que há três pólos importantes no Brasil: um localizado em Limeira, no Estado de São Paulo; outro localizado em Guaporé, no Rio Grande do Sul e outro localizado em Juazeiro do Norte, no Ceará. O principal pólo é o da cidade de Limeira, que é considerada como a "capital dos folheados", produzindo $60 \%$ das joias, semijoias e bijuterias do país. Dentro do termo galvanotécnica, estão englobadas todas as outras empresas de galvanoplastia, como cobreação, niquelação, cromação, latonagem, estanhagem, zincagem, cadmiação e outras.

Pelos dados da RAIS $/ 2005^{48}$, estes dois grupos empregam, no Brasil, 52.481 trabalhadores, em 4.577 empresas, distribuídos conforme TAB. 1. O Estado de São Paulo concentra $48 \%$ das indústrias e $56 \%$ dos trabalhadores do segmento, conforme TAB. 2.

Tanto para o Brasil quanto para o Estado de São Paulo, nota-se que a quase totalidade das empresas é de micro e pequeno porte (99\%), existindo poucas empresas de médio porte (1\%). Observa-se que não há empresas de grande porte.

As porcentagens também são expressivas em relação ao número de trabalhadores, no qual nota-se que a grande maioria atua nas micro e pequenas empresas. No Brasil são $87 \%$ e no Estado de São Paulo são $89 \%$ dos trabalhadores. 
Nas TAB. 1 e 2, ainda é possível observar que a indústria de folheados corresponde a aproximadamente um terço das demais empresas de galvanoplastia, no Brasil, e que, para o Estado de São Paulo, este número equivale a aproximadamente um quarto, demonstrando, mais uma vez, a importância da empresa de folheados. Depois das empresas de folheação, as empresas de zincagem e cromação são as mais numerosas, porém, com a quantidade de unidades não encontrada na literatura ${ }^{48}$.

TABELA 1 - Estabelecimentos de galvanoplastia e trabalhadores (Brasil, 2005)

\begin{tabular}{c|c|c|c|c|c|c}
\hline \multirow{2}{*}{ Porte } & \multicolumn{2}{|c|}{ Galvanotécnica } & \multicolumn{2}{c|}{ Folheados } & \multicolumn{2}{c}{ Total } \\
\cline { 2 - 7 } & Empresas & $\mathbf{N}^{\circ}$ Trab. & Empresas & $\mathbf{N}^{\circ}$ Trab. & Empresas & $\mathbf{N}^{\circ}$ Trab. \\
\hline \multirow{2}{*}{ Micro } & 2.862 & 16.509 & 1.051 & 5.503 & 3.913 & 22.012 \\
\cline { 2 - 7 } & $(85 \%)$ & $(41 \%)$ & $(88 \%)$ & $(45 \%)$ & $(85 \%)$ & $(42 \%)$ \\
\hline \multirow{2}{*}{ Pequeno } & 485 & 18.528 & 136 & 4.851 & 621 & 23.379 \\
\cline { 2 - 7 } & $(14 \%)$ & $(46 \%)$ & $(11 \%)$ & $(40 \%)$ & $(14 \%)$ & $(45 \%)$ \\
\hline \multirow{2}{*}{ Médio } & 30 & 5.252 & 13 & 1.838 & 43 & 7.090 \\
\cline { 2 - 7 } & $(1 \%)$ & $(13 \%)$ & $(1 \%)$ & $(15 \%)$ & $(1 \%)$ & $(13 \%)$ \\
\hline Total & 3.377 & 40.289 & 1.200 & 12.192 & 4.577 & 52.481 \\
\hline
\end{tabular}

FONTE: Arquivo RAIS Estabelecimento - 2005

NOTA: $N^{\circ}$ Trab. $=$ Número de trabalhadores

TABELA 2 - Estabelecimentos de galvanoplastia e trabalhadores (São Paulo, 2005)

\begin{tabular}{c|c|c|c|c|c|c}
\hline \multirow{2}{*}{ Porte } & \multicolumn{2}{|c|}{ Galvanotécnica } & \multicolumn{2}{c|}{ Folheados } & \multicolumn{2}{c}{ Total } \\
\cline { 2 - 7 } & Empresas & $\mathbf{N}^{\circ}$ Trab. & Empresas & $\mathbf{N}^{\circ}$ Trab. & Empresas & $\mathbf{N}^{\circ}$ Trab. \\
\hline \multirow{2}{*}{ Micro } & 1.422 & 9.266 & 380 & 2.427 & 1.802 & 11.693 \\
\cline { 2 - 7 } & $(81 \%)$ & $(39 \%)$ & $(86 \%)$ & $(45 \%)$ & $(82 \%)$ & $(40 \%)$ \\
\hline \multirow{2}{*}{ Pequeno } & 314 & 12.130 & 56 & 1.878 & 370 & 14.008 \\
\cline { 2 - 7 } & $(18 \%)$ & $(51 \%)$ & $(13 \%)$ & $(35 \%)$ & $(17 \%)$ & $(49 \%)$ \\
\hline \multirow{2}{*}{ Médio } & 16 & 2.472 & 7 & 1.031 & 24 & 3.503 \\
\cline { 2 - 7 } & $(1 \%)$ & $(10 \%)$ & $(1 \%)$ & $(20 \%)$ & $(1 \%)$ & $(11 \%)$ \\
\hline Total & 1.752 & 23.868 & 443 & 5.336 & 2.195 & 29.204 \\
\hline
\end{tabular}

FONTE: Arquivo RAIS Estabelecimento - 2005

NOTA: $N^{\circ}$ Trab. = Número de trabalhadores

\subsubsection{Tipos de tratamento de superfícies}

O setor de tratamento de superfícies tem aplicação nos seguintes ramos de atividade: indústria automotiva; indústria de bijuterias; construção civil; 
indústria de utensílios domésticos; indústria de informática; indústria de telefonia; recuperação de objetos decorativos e outros. As empresas geralmente possuem os processos de: cromação; cobreação; niquelação; latonagem; estanhagem; zincagem; douração, prateação e demais aplicações para bijuterias, com banhos de ródio e platina; cadmiação; ZnNi e outros banhos de liga; anodização; banhos químicos, como níquel químico e cobre químico; oxidação negra; fosfatização; pintura e outros ${ }^{49}$. A função de cada empresa é apresentada a seguir, dando-se ênfase ao processo de cromação, por ter sido focado neste trabalho.

1) Cromação ${ }^{49,50}$ :

As empresas de cromação utilizam banhos de cobre (cobre alcalino e cobre ácido), níquel brilhante e cromo hexavalente, na maioria dos casos. Algumas só possuem banhos de níquel brilhante e cromo hexavalente.

A camada de cobre depositada por meio do banho de cobre alcalino tem a função de proporcionar uma melhor aderência dos revestimentos posteriores e é aplicada em espessuras de 0,5 $\mu \mathrm{m}$ a $5 \mu \mathrm{m}$, aproximadamente. Para bases de latão, este tratamento não é necessário, pois o latão já é constituído por liga de cobre e proporciona diretamente boa aderência do cobre ácido ou do níquel. A camada de cobre depositada por meio do banho de cobre ácido tem a função de nivelar a superfície, proporcionando brilho, além de também contribuir para a proteção contra a corrosão. Sua espessura varia geralmente entre $5 \mu \mathrm{m}$ e $20 \mu \mathrm{m}$. A camada de níquel depositada por meio do banho de níquel brilhante tem como principal objetivo oferecer a proteção contra a corrosão, propriamente dita, devido às suas características mecânicas e químicas. A espessura aplicada normalmente varia entre $5 \mu \mathrm{m}$ e $35 \mu \mathrm{m}$. Como última camada, o revestimento de cromo depositado por meio do banho de cromo hexavalente tem a função estética, com o objetivo de evitar a exposição do níquel, pois pode escurecer se exposto diretamente ao ar. As camadas aplicadas são pouco espessas, sendo da ordem de 0,05 $\mu \mathrm{m}$ a 0,3 $\mu \mathrm{m}$. Em geral, os valores de espessura variam de acordo com a exigência do cliente, podendo ser maiores ou menores. Existem normas nacionais e internacionais que determinam a espessura mínima que deve ser aplicada em diferentes substratos, para que a peça adquira boa resistência à corrosão. 
As composições aproximadas de todos os banhos geralmente utilizados nas empresas de cromação estão apresentadas na TAB. 3, onde se pode notar que são extremamente perigosas ao meio ambiente e à saúde humana, devido à presença de metais pesados, cianeto, cromo hexavalente, além de ácido e base fortes ${ }^{51}$.

TABELA 3 - Composições das soluções químicas utilizadas nas empresas de cromação

\begin{tabular}{|c|c|}
\hline Solução & $\begin{array}{l}\text { Composição aproximada básica, excetuando-se os } \\
\text { aditivos - soluções aquosas }\end{array}$ \\
\hline Desengraxante químico & \multirow{2}{*}{$\begin{array}{c}60 \mathrm{~g} / \mathrm{L} \text { a } 80 \mathrm{~g} / \mathrm{L} \text { de } \mathrm{NaOH} \text { (em alguns casos, com cerca de } \\
20 \mathrm{~g} / \mathrm{L} \text { a } 40 \mathrm{~g} / \mathrm{L} \text { de } \mathrm{NaCN} \text { e outras substâncias em menores } \\
\text { proporções como metassilicatos e carbonatos) }\end{array}$} \\
\hline Desengraxante eletrolítico & \\
\hline Ativação ácida & $10 \% \mathrm{v} / \mathrm{v}$ de $\mathrm{H}_{2} \mathrm{SO}_{4}$ \\
\hline Banho de cobre alcalino & $40 \mathrm{~g} / \mathrm{L}$ CuCN, $55 \mathrm{~g} / \mathrm{L}$ de $\mathrm{NaCN}$ e $10 \mathrm{~g} / \mathrm{L}$ de $\mathrm{NaOH}$ \\
\hline Banho de cobre ácido & $220 \mathrm{~g} / \mathrm{L}$ de $\mathrm{CuSO}_{4}$ e $60 \mathrm{~g} / \mathrm{L}$ de $\mathrm{H}_{2} \mathrm{SO}_{4}$ \\
\hline $\begin{array}{l}\text { Banho de níquel brilhante tipo } \\
\text { Watts }\end{array}$ & $250 \mathrm{~g} / \mathrm{L}$ de $\mathrm{NiSO}_{4}, 50 \mathrm{~g} / \mathrm{L}$ de $\mathrm{NiCl}_{2}$ e $45 \mathrm{~g} / \mathrm{L}$ de $\mathrm{H}_{3} \mathrm{BO}_{3}$ \\
\hline Banho de cromo hexavalente & $250 \mathrm{~g} / \mathrm{L}$ de $\mathrm{CrO}_{3}$ e $2,5 \mathrm{~g} / \mathrm{L}$ de $\mathrm{H}_{2} \mathrm{SO}_{4}$ \\
\hline
\end{tabular}

Em relação aos demais processos de galvanoplastia, é importante mencionar que algumas empresas exercem mais de uma atividade ao mesmo tempo. É comum serem utilizadas atividades conjuntas de cromação e niquelação; ou de cromação, niquelação e cobreação; ou ainda de niquelação e cobreação e, por isto, é interessante diferenciá-los.

2) Niquelação ${ }^{49,52}$ :

É denominado de niquelação, o processo que possui somente banhos de cobre e níquel ou somente de níquel. Clipes, chaves e outras peças passam somente pelo processo de niquelação, não recebendo revestimento de cromo final.

3) Cobreação ${ }^{49,50}$ :

É denominado de cobreação, o processo que possui somente banhos de cobre. Fios condutores, placas de circuito e outras peças passam somente pelo processo de cobreação.

4) Latonagem ${ }^{49,53}$ : 
A latonagem é o processo constituído por banhos de cobre, níquel e latão, para simular uma peça dourada. É muito empregada para metais sanitários. Facilmente encontram-se no mercado, por exemplo, torneiras "douradas", que na verdade são latonadas. Muitas destas peças latonadas também passam por um processo de oxidação, denominado envelhecimento, para oferecer um acabamento estético conhecido como "ouro velho".

5) Estanhagem ${ }^{49,54}$ :

A estanhagem é o processo constituído por banhos de cobre e estanho alcalino ou estanho ácido, para revestir peças que comportam alimentos, ou peças para o setor eletroeletrônico, ou mesmo para substituir o níquel em bijuterias e outras peças, que são exportadas para a Europa, pois o níquel causa alergia na pele de muitas pessoas, principalmente, de mulheres.

6) Zincagem ${ }^{49,54}$ :

A zincagem é o processo constituído por banho de zinco alcalino ou zinco ácido, para revestir peças de aço-carbono do setor automotivo e de engenharia em geral, como de construção civil, de máquinas, ferramentas e outras.

7) Douração, prateação e demais aplicações para bijuterias, como ródio e platina $^{49,52-55}$ :

A douração é o processo constituído por banhos de cobre, níquel, pré ouro, ouro folheação e ouro cor, para o setor de folheados/bijuterias. A prateação é o processo constituído por banhos de cobre, pré prata e prata, também para o setor de folheados/bijuterias. Os revestimentos de ródio ou platina têm a mesma finalidade do ouro e da prata, e também geralmente recebem camadas anteriores de cobre e níquel, sendo aplicados para o setor de folheados/bijuterias.

8) Cadmiação ${ }^{49,50}$ :

A cadmiação é o processo constituído por banho de cádmio, para revestir, principalmente, peças do setor de aviação e de engenharia em geral.

9) ZnNi e outros banhos de liga ${ }^{49,56}$ :

O processo de ZnNi é constituído por banho de liga de zinco/níquel e, assim como os banhos de $\mathrm{ZnCo}$, ZnFe e outros, são empregados para revestir peças de aço-carbono do setor automotivo e de engenharia em geral, que exigem maior resistência à corrosão em relação às peças simplesmente zincadas. 
Como processos alternativos de tratamento de superfícies, que não podem ser chamados de galvanoplastia, estão, por exemplo, a anodização, envolvendo corrente, e os banhos químicos, oxidação negra e fosfatização, sem a aplicação de corrente. Ainda há o processo de pintura, que pode ou não envolver corrente. Todos estes são mencionados a seguir.

10) Anodização ${ }^{49,57}$ :

A anodização é o processo no qual o alumínio e suas ligas são submetidos à oxidação forçada, formando uma camada protetora, isolante e com alta dureza.

11) Ni químico e Cu químico ${ }^{49,58}$ :

Os banhos químicos são constituídos por ligas metálicas e são utilizados para revestir superfícies de geometria desfavorável ao processo eletrolítico ou mesmo para proporcionar melhor resistência à corrosão em relação às mesmas espessuras de banhos de níquel e cobre. O banho de níquel químico é o mais utilizado e é constituído por uma liga de níquel e fósforo. Ambos também podem ser utilizados como etapa final da preparação de superfícies não metálicas, como, por exemplo, ABS, para receber os revestimentos convencionais posteriores de cobre, níquel e cromo.

12) Oxidação negra ${ }^{49,59}$ :

A oxidação negra é o processo constituído por banho contendo uma mistura de ácidos, que promove uma oxidação na superfície do aço, em temperatura de cerca de $130^{\circ} \mathrm{C}$, criando uma camada de óxido aderente de coloração preta, para peças automotivas e de engenharia em geral.

13) Fosfatização ${ }^{49,59}$ :

A fosfatização é o processo constituído por banho de fosfato, para preparar peças para a pintura ou mesmo para promover revestimento final de fosfato, em peças automotivas e de engenharia em geral, neste caso, com aplicação de oleamento posterior.

14) Pintura ${ }^{49,59}$ :

A pintura possui diversas formas de aplicação, como por imersão envolvendo corrente elétrica (pintura cataforética), por imersão sem corrente elétrica, por pistola, pelo método eletrostático (pintura a pó) e outras, e é muito utillizada para revestir eletrodomésticos e automóveis, além de diversas outras peças em diversos segmentos. 


\subsubsection{Etapas do processo de galvanoplastia}

O processo de galvanoplastia pode ser dividido, de forma simplificada, em três etapas: pré-tratamento; tratamento e pós-tratamento ${ }^{48}$.

1) Pré-tratamento $0^{60,61}:$ o pré-tratamento consiste na preparação da superfície a ser tratada, por meio mecânico ou químico, para que o revestimento tenha boa aderência, uniformidade e aparência.

- Pré-tratamento mecânico ${ }^{60}$ - escovação, lixamento, polimento e jateamento, utilizando escovas de aço ou latão, rolos de esmeril ou de lixas, e outros materiais abrasivos, para a remoção de rebarbas, sulcos, irregularidades, camadas de óxidos e resíduos de tintas e de solda;

- Pré-tratamento químico ${ }^{61}$ - desengraxe e decapagem:

- desengraxe químico - realizado com solventes clorados como tricloroetileno e percloroetileno;

- desengraxe químico - podendo ser feito com carbonato de sódio, hidróxido de sódio, fosfato, silicato, detergentes sintéticos, cianeto ou complexantes tipo EDTA, glutamato e citrato de sódio;

- desengraxe eletroquímico - no qual a peça é polarizada, catodicamente, anodicamente ou alternadamente, num meio alcalino, composto com reagentes similares aos do desengraxante químico;

- decapagem - realizada numa solução ácida, geralmente ácido clorídrico, sulfúrico ou fluorídrico, para a remoção de camada de óxidos ou outras impurezas sólidas.

2) Tratamento ${ }^{49,62}$ : na etapa de tratamento, a peça é ligada ao pólo negativo de uma fonte de corrente contínua proveniente de um retificador, tornando-se catodo, onde ocorre a eletrodeposição. Os anodos utilizados podem ser solúveis ou insolúveis. $O$ tratamento se desenvolve numa sequência de banhos, conforme já mencionado anteriormente.

3) Pós-tratamento ${ }^{48}$ : na etapa de pós-tratamento, as peças podem passar pelos processos de lavagem com água fria ou quente; secagem em centrífuga, estufa ou jatos de ar; banho de óleo para embalagem e proteção e envernizamento, para encaminhamento para embalagem, estoque e expedição. 


\subsubsection{Riscos ocupacionais na galvanoplastia}

Riscos ocupacionais são aqueles decorrentes da organização, dos procedimentos, da maquinaria, dos processos, dos ambientes e das relações de trabalho que podem comprometer a segurança e a saúde dos trabalhadores. São classificados em cinco categorias: físicos, químicos, biológicos, ergonômicos e de acidentes, e provêm de agentes que, dependendo da sua natureza, concentração, intensidade e tempo de exposição, podem causar danos à segurança e à saúde dos trabalhadores ${ }^{48}$.

$\mathrm{Na}$ indústria galvânica, o risco principal é o químico, devido à nocividade dos compostos manipulados. Os riscos químicos são causados pelos agentes que interagem com tecidos humanos, provocando alterações na sua estrutura e que podem penetrar no organismo pelo contato com a pele, por ingestão e pela via respiratória. Os fatores que determinam o risco são a forma de manipulação dos produtos químicos, a dispersão dos agentes no ambiente de trabalho e o nível de proteção dos trabalhadores ${ }^{48}$.

A seguir estão citados alguns agentes químicos utilizados na galvanoplastia, nos processos de cromação, que podem causar sérios danos à saúde humana, desde que não geridos com a utilização de equipamentos de proteção individual (EPIs) e demais cuidados necessários ${ }^{10,48}$.

- Hidróxido de sódio: o contato com a pele e olhos produz queimaduras graves e lesões com possível cegueira. A inalação pode causar queimaduras nas vias respiratórias e edema pulmonar. A ingestão causa perfuração dos tecidos das membranas das mucosas da boca, garganta e estômago.

- Cianeto de sódio: causa irritação na garganta e nariz, tosse e dificuldade respiratória. Acima de certas concentrações variáveis para cada ser humano causa cefaleia, confusão mental, vertigem, taquicardia, inconsciência e morte.

- Ácido clorídrico: causa inflamação de vias aéreas superiores, provocando tosse e sufocamento. Causa queimaduras graves. Pode danificar a visão. A ingestão provoca diarreia e perfurações na boca e no trato gastrointestinal.

- Cianeto de cobre: é extremamente irritante aos olhos, causando dor e queimaduras de córnea. Pode causar irritação no sistema respiratório, alteração na respiração e edema pulmonar. É altamente tóxico se ingerido, ocasionando dor de cabeça, perda de consciência, falta de ar, desmaios, parada respiratória e morte. 
- Sulfato de cobre: o contato com a pele causa eczema. O contato com os olhos causa conjuntivite, edema de pálpebras, ulcerações e turbidez de córnea. A ingestão provoca gosto metálico na boca, dores epigástricas, vômitos repetidos e diarreia, dores de cabeça, taquicardia, dificuldades respiratórias, falência hepática e renal e, em casos mais severos, ulcerações no trato gastrintestinal. Nos casos letais, a morte é precedida de hemorragia gástrica, taquicardia, crise hemolítica, convulsões e paralisia.

- Ácido sulfúrico: o contato com a pele e olhos produz queimaduras graves e lesões com possível cegueira. A inalação pode causar tosse, espirros, sangramento nasal, dificuldade respiratória e edema pulmonar. A ingestão causa corrosão das membranas, mucosas da boca, garganta e esôfago.

- Sulfato de níquel: causa irritação e alergia aos olhos e à pele e ao aparelho respiratório. A inalação prolongada pode provocar graves doenças respiratórias e danos aos pulmões, irritação e obstrução das vias aéreas. Se for ingerido causa irritação no trato digestivo, dores abdominais, diarreia, náuseas e vômitos.

- Cloreto de níquel: causa dermatites de contato. É irritante para olhos e mucosas. A ingestão causa náuseas, vômitos, desconforto abdominal, tontura, fadiga, dor de cabeça e respiração ofegante.

- Ácido bórico: danoso se for aspirado ou inalado. Causa irritação à pele, olhos e trato respiratório. Afeta o sistema nervoso central, fígado e rins.

- Ácido crômico/cromo hexavalente: causa queimaduras graves na pele ou olhos e, em exposições prolongadas, pode produzir perfuração do septo nasal. É tóxico se for ingerido ou inalado, podendo causar problemas no trato respiratório, inclusive câncer. Compostos solúveis de cromo hexavalente são considerados do grupo A1 (cancerígenos) pela American Conference of Industrial Hygienists (ACGIH).

- Ferro: a intoxicação pode causar diarreia, vômitos, aumento do número de glóbulos brancos, aumento do valor de glicose no sangue (hiperglicemia), lesões intestinais, adormecimento e perda de conhecimento.

- Zinco: a ingestão pode produzir sabor metálico, vômitos, diarreia e problemas no estômago. A ingestão de $1 \mathrm{~g}$ ou mais pode ser mortal.

- Cobre: é um mineral essencial ao funcionamento do nosso organismo. Na deficiência de zinco, geralmente o cobre encontra-se aumentado. $O$ cobre 
deposita-se preferencialmente no cérebro e no fígado e os sintomas encontrados são inicialmente decorrentes do comprometimento destes dois órgãos. Sintomas do excesso de cobre ligados às alterações cerebrais incluem: distúrbios emocionais, depressão, nervosismo e irritabilidade, sintomas semelhantes aos do mal de Parkinson e alterações semelhantes à esquizofrenia e a outros distúrbios psiquiátricos. Outras alterações ligadas ao excesso de cobre são fadiga, dores musculares e nas juntas, anemia hemolítica, queda de vitamina $A$, necrose hepática, icterícia e lesão renal.

- Níquel: o níquel causa irritação e alergia aos olhos, à pele e ao aparelho respiratório. A inalação prolongada pode provocar graves doenças respiratórias e danos aos pulmões, irritação e obstrução das vias aéreas. Se ingerido, causa irritação no trato digestivo, dores abdominais, diarreia, náuseas e vômitos.

- Estanho: pode causar edema, náuseas, vômitos, dores abdominais, diarreia e cefaleia.

- Alumínio: a intoxicação em altas concentrações causa danos cerebrais graves, inclusive fatais.

- Chumbo: a intoxicação pode causar falta de apetite, gosto metálico na boca, desconforto muscular, mal estar, dor de cabeça e cólicas abdominais fortes.

\subsubsection{Tratamento de efluentes na galvanoplastia}

Todos os efluentes das empresas de galvanoplastia geralmente são direcionados a uma Estação de Tratamento de Efluentes (ETE), onde são tratados, resultando numa parte líquida "limpa", que pode ser descartada na rede coletora de esgotos ou em coleções de água (córregos ou rios), desde que atendendo às regulamentações específicas, e numa parte sólida, onde ficam concentradas todas as substâncias consideradas perigosas ${ }^{63}$.

Muitas vezes, os procedimentos das etapas de tratamento de efluentes não são executados de forma correta e acabam lançando substâncias nocivas aos corpos d'água, além do agravante de muitas empresas não tratarem seus efluentes. Existem até casos de empresas que possuem ETE somente para efeito de legalidade frente aos órgãos ambientais, mas não tratam seus efluentes, pois o custo é elevado e nem sempre pode ser embutido no valor de comercialização 
dos produtos, pois o produto se torna caro em comparação aos valores já aceitos pelo mercado.

Se o tratamento de efluentes é realizado, resíduos sólidos são gerados, e estes são armazenados na quase totalidade dos casos, ainda que por tempo limitado. Destinar o resíduo é custoso e também nem sempre é viável comercialmente agregar tal custo ao valor do produto. Para o armazenamento destes resíduos, existem normas a serem seguidas, no entanto, em grande parte dos casos elas não são obedecidas. A consequência desta situação é a criação de um "passivo ambiental", que pode atingir a saúde dos trabalhadores e inclusive da população vizinha, em caso de acidentes ambientais.

\subsection{Micro e Pequenas Empresas (MPEs), meio ambiente e população}

As empresas de galvanoplastia são, em sua maioria, de micro ou pequeno porte, conforme anteriormente mencionado nas TAB. 1 e 2. Segundo o SEBRAE ${ }^{64}$, conforme o disposto no artigo $3^{\circ}$ da Lei Geral das Microempresas e das Empresas de Pequeno Porte (Lei Complementar № 123, de 14 de dezembro de 2006), a definição de MPE é dada de acordo com o seguinte critério:

- Microempresas: empresas cujo faturamento anual seja inferior ou igual a $\mathrm{R} \$ 240.000,00$ (duzentos e quarenta mil reais), com no máximo 19 empregados;

- Empresas de Pequeno Porte: empresas cujo faturamento anual seja superior a $R \$ 240.000,00$ (duzentos e quarenta mil reais) e inferior ou igual a $\mathrm{R} \$ 2.400 .000,00$ (dois milhões e quatrocentos mil reais), com 20 a 99 empregados.

De acordo com o SEBRAE-SP ${ }^{64}$, no Brasil existem 5.110.285 empresas e, deste total, 98\% são micro ou pequenas. As MPEs respondem por $67 \%$ das pessoas ocupadas e $20 \%$ do PIB (FIG. 4). Cerca de $56 \%$ das MPEs encontram-se no comércio, 30\% em serviços e 14\% na indústria. Com respeito às médias e grandes empresas (MGEs), as proporções são diferentes: $72 \%$ dos estabelecimentos encontram-se no setor de serviços, 14\% no comércio e $14 \%$ na indústria. Além disto, as MPEs empregam 56\% dos trabalhadores com carteira assinada (CLT) e contribuem com 2,3\% do valor das exportações. Entre 2000 e 2004, foram abertos 924 mil novos estabelecimentos, dos quais $99 \%$ eram de micro e pequeno porte. 


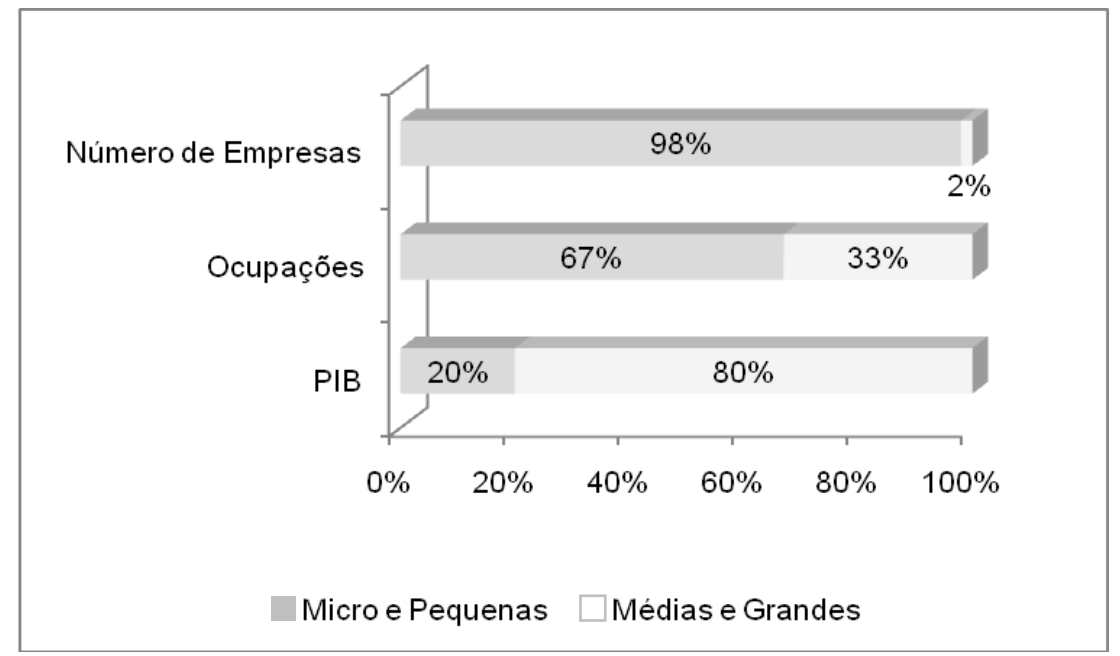

FIGURA 4 - As MPEs e as MGES na economia. Fonte: SEBRAE-SP

No Estado de São Paulo, em $2004^{64}$, no grupo das MPEs, existiam 1.544.065 empresas (30,2\% do total de empresas no Brasil), sendo 817.779 estabelecimentos no comércio (53\%), 531.823 no setor de serviços (34\%) e 194.463 na indústria (13\%). Entre 2000 e 2004, o número de MPEs saltou de 1,255 milhão para 1,544 milhão (aumento de 23\%). No mesmo período, foram abertos no Estado 293 mil novos estabelecimentos (criação líquida), dos quais 98\% (ou quase 288 mil) foram de micro e pequeno porte e houve a criação líquida de 872 mil novos empregos com carteira assinada (CLT), dos quais 55\% (475 mil novos empregos) foram criados por MPEs.

Na região metropolitana de São Paulo (RMSP), ou grande São Paulo, em 2004, no grupo das MPEs, existiam 759.137 empresas (14,9\% do total de empresas no Brasil), sendo 354.505 estabelecimentos no comércio (47\%), 309.356 no setor de serviços (41\%) e 95.276 na indústria $(12 \%)^{64}$.

Na zona leste de São Paulo, segundo dados do Ministério do Trabalho, existem 93.000 empresas formais ${ }^{65}$. O número de MPEs não foi encontrado, mas provavelmente mantém uma porcentagem próxima a $100 \%$, assim como para o Brasil e para o Estado de São Paulo.

Apesar das estatísticas apresentadas acima, é importante mencionar que das MPEs paulistas, $29 \%$ fecham em seu $1^{\circ}$ ano de atividade e $56 \%$ não completam o $5^{\circ}$ ano de vida (FIG. 5). Estes dados demonstram a fragilidade destas empresas, cujos motivos do fechamento estão apresentados na FIG. $6^{64}$. 


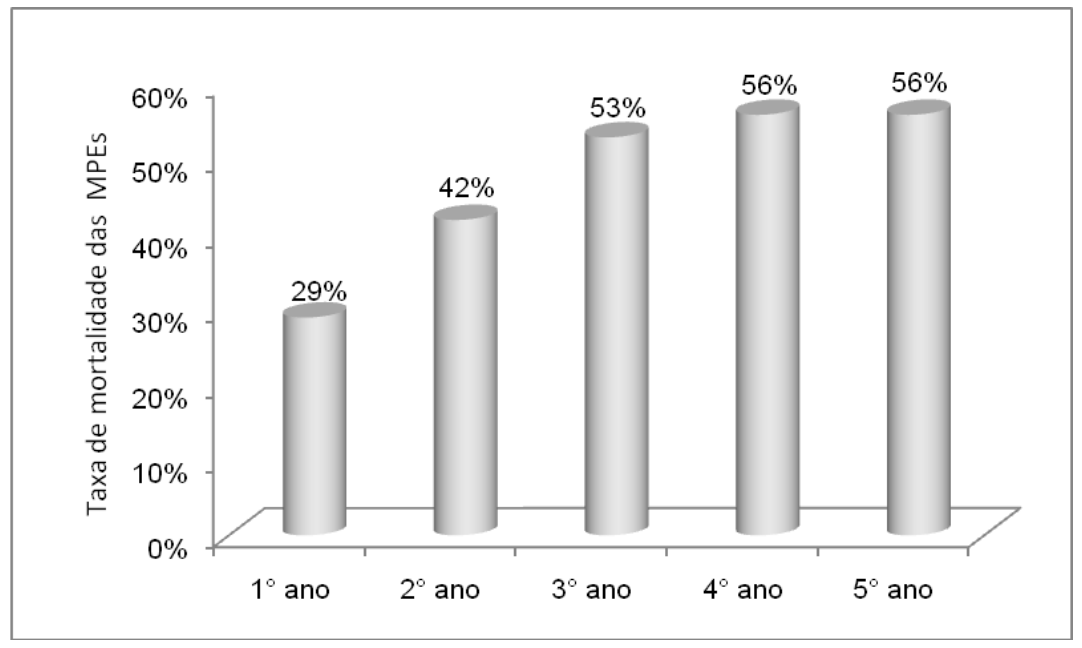

FIGURA 5 - Taxa de mortalidade das MPEs paulistas. Fonte: SEBRAE-SP

No gráfico ilustrado na FIG. 6, nota-se que o principal fator de encerramento das empresas é a falta de capital (25\%). Evidentemente, com tais dificuldades, estas empresas se preocuparam pouco com a questão ambiental, devido aos altos custos que isto exige. As MPEs, principalmente do setor da indústria, possuem maior potencial poluidor. Apesar de, individualmente, cada MPE gerar pouco resíduo, a soma de toda a quantidade gerada é preocupante. As MGEs, individualmente, geram uma quantidade muito maior de resíduos em comparação a cada MPE, mas em grande parte dos casos têm uma política de controle ambiental e investem em tecnologia para tratar seus resíduos.

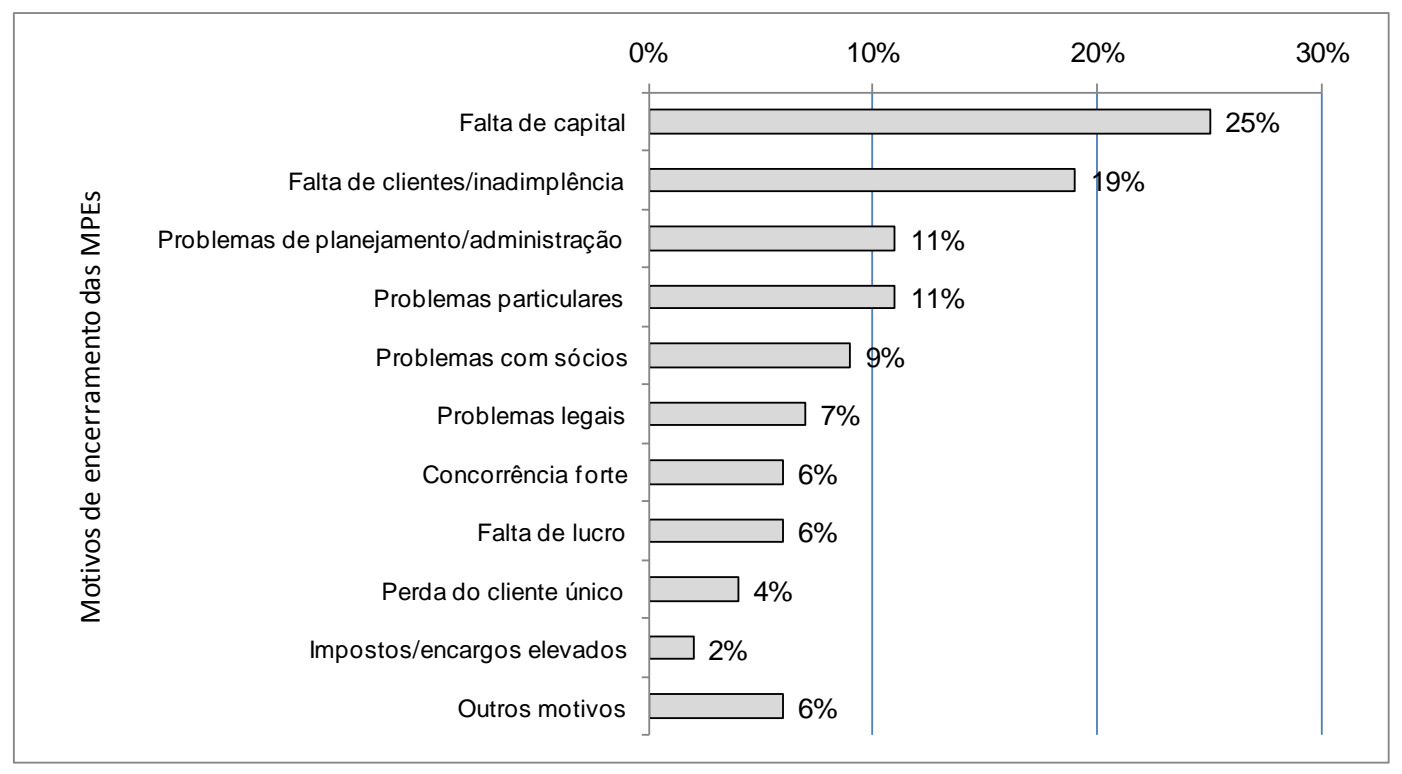

FIGURA 6 - Motivos de mortalidade das MPEs. Fonte: SEBRAE-SP

Há uma concentração de micro e pequenas empresas de cromação na região leste da cidade de São Paulo. A zona leste de São Paulo é a região mais 
populosa da cidade, com cerca de 3,3 milhões de pessoas (cerca de $30 \%$ da população total da cidade), segundo dados da Prefeitura de São Paulo, mencionados pelo SEBRAE ${ }^{65}$. Estas estatísticas exibem a importância da região da zona leste frente à cidade, ao Estado e ao país, conforme os dados do último censo populacional apresentado pelo $\mathrm{IBGE}^{66}$, divulgado em 04 de novembro de 2010, ilustrados na TAB. 4, tornando-se relevante um estudo ambiental, visto que milhões de pessoas podem ser afetadas com o alto risco das atividades industriais ambientalmente inconsequentes.

$\mathrm{Na}$ TAB. 4 estão apresentados apenas os resultados levantados para o Brasil, o Estado de São Paulo e o município de São Paulo e observa-se, na coluna destacada em itálico e negrito, à direita, o contraste no elevado número de habitantes por quilômetro quadrado apresentado pela cidade de São Paulo, que é considerada a região de maior concentração de pessoas do país. Este fenômeno se deve em parte ao potencial de oportunidades associada à intensa atividade industrial local.

TABELA 4 - Dados populacionais, segundo IBGE, em 04/11/2010

\begin{tabular}{c|c|c|c}
\hline Região & $\mathbf{N}^{\circ}$ de habitantes & Área aproximada $\left(\mathbf{k m}^{2}\right)$ & Habitantes $/ \mathbf{k m}^{\mathbf{2}}$ \\
\hline Brasil & 190.732 .694 & 8.514 .877 & $\mathbf{2 2 , 4}$ \\
\hline Estado de São Paulo & 41.252 .160 & 248.197 & $\mathbf{1 6 6 , 2}$ \\
\hline Município de São Paulo & 11.244 .369 & 1.523 & $\mathbf{7 . 3 8 3}$ \\
\hline
\end{tabular}

A zona leste da cidade de São Paulo é ainda mais povoada que a cidade de São Paulo. Nela se concentram aproximadamente 11.000 habitantes por quilômetro quadrado, segundo os dados da Prefeitura de São Paulo, mencionados pelo SEBRAE ${ }^{65}$, tornando ainda mais grave as consenquências em caso de acidentes ambientais. Mesmo não havendo acidentes, a proximidade das moradias às instalações industriais é um risco à população.

\subsection{Projeto de Unidades Móveis do setor de tratamento de superfícies (PRUMO/TS)}

O Instituto de Pesquisas Tecnológicas do Estado de São Paulo (IPT), em consonância com a Secretaria de Desenvolvimento Econômico, Ciência e Tecnologia do Estado de São Paulo (SDECT), com a Financiadora de Estudos e 
Projetos (FINEP), com a Fundação de Amparo à Pesquisa do Estado de São Paulo (FAPESP) e com o Serviço Brasileiro de Apoio às Micro e Pequenas Empresas (SEBRAE-SP), opera um programa de atendimento tecnológico às micro, pequenas e médias empresas (MPMEs), por meio de Unidades Móveis. Estas unidades são veículos utilitários dotados de equipamentos laboratoriais e vão até as empresas, identificam os problemas por elas enfrentados, realizam ensaios e análises e apresentam soluções tecnológicas ${ }^{67}$.

O objetivo do programa é aprimorar os processos e produtos das MPMEs, para melhorar a competitividade industrial, fazê-las manter e conquistar mercados e atender as exigências do consumidor ${ }^{67}$.

No caso específico do setor de Tratamento de Superfícies (PRUMO/TS), uma Unidade Móvel vêm realizando atendimentos tecnológicos desde o ano de 2002, atuando na resolução de problemas de processos, complementando a assessoria prestada pelos fornecedores de insumos e contribuindo, desta forma, para a melhoria do produto final, visando tornar a empresa mais competitiva no mercado nacional e internacional ${ }^{67}$.

Esta ação proativa surgiu devido às inúmeras dificuldades enfrentadas pelas MPMEs, tais como a falta de conhecimento técnico, a falta de acesso à literatura e aos institutos de pesquisas, além das dificuldades econômicas, e devido à importância da MPME no país.

Durante a realização dos atendimentos tecnológicos às empresas do setor de tratamento de superfícies, foi observada a problemática ambiental do armazenamento dos resíduos sólidos dentro das próprias empresas, com riscos de contaminação da região e da população ao redor, em particular, na zona leste da cidade de São Paulo, com elevada densidade demográfica, e isto idealizou a criação deste trabalho. Foi por meio das empresas atendidas pelo PRUMO/TS que foram selecionadas as empresas que contribuíram para este estudo. 


\section{MATERIAIS E MÉTODOS}

O presente estudo foi desenvolvido em duas frentes, que se complementam, mas são mencionadas individualmente, devido às suas características próprias. A primeira parte envolveu um levantamento de dados nas empresas de cromação situadas na zona leste do município de São Paulo, no qual foi avaliada a situação destas indústrias em termos socioeconômicos e ambientais, dando-se ênfase aos fatores relacionados à geração dos resíduos sólidos, e a segunda parte envolveu a caracterização química e físico-química dos resíduos sólidos galvânicos selecionados e a utilização funcional de seus constituintes na formulação de vidros silicatos, com o objetivo de mitigar os efeitos nocivos ao meio ambiente e à saúde humana.

\subsection{Parte A - Levantamento de dados nas empresas de galvanoplastia da zona leste da cidade de São Paulo}

Os materiais e métodos utilizados na primeira parte do trabalho envolveram a seleção do conjunto de empresas a serem avaliadas sob o aspecto de seus passivos ambientais e a coleta de dados in loco, visando obter um parâmetro ambiental de tais empresas na região onde estão situadas.

\subsubsection{Seleção das empresas}

Inicialmente, o setor de cromação foi selecionado para o estudo, devido ao seu potencial de risco ambiental. Pelas atividades executadas pelo PRUMO/TS, que atua intensamente junto aos processos de galvanoplastia, observou-se que o setor de cromação se concentra na zona leste do município de São Paulo, que, como anteriormente mencionado, é a região de maior densidade demográfica e merece atenção detalhada direcionada às questões voltadas ao meio ambiente.

Com base no universo de aproximadamente 30 empresas de cromação atendidas pelo PRUMO/TS na zona leste da cidade de São de Paulo, mais de $50 \%$ (17 empresas) contribuíram com este estudo, atendendo à solicitação da verificação de suas formas de atuação, principalmente, no que tange a geração de seus resíduos sólidos. 


\subsubsection{Levantamento de dados relativos à geração de resíduos sólidos galvânicos}

Para o estudo, as empresas responderam a um questionário estruturado, com questões abertas e principalmente fechadas ${ }^{68}$, elaborado a partir da adaptação do questionário utilizado pelo PRUMO/TS.

Este questionário foi direcionado para a coleta de dados que permitisse fornecer um panorama da atuação socioeconômica, produtiva e ambiental destas empresas na zona leste da cidade de São Paulo, tendo como foco a geração dos resíduos sólidos galvânicos. O questionário, na íntegra, está apresentado no APÊNDICE.

As empresas visitadas foram numeradas de 1 a 17 e suas localidades estão apresentadas na FIG. 7. Suas identidades foram preservadas, apesar de todas terem aceito mencionar seus nomes no trabalho, com o objetivo de não privilegiar qualquer empresa ou exacerbar qualquer tipo de concorrência.

\subsection{Parte B - Aplicação tecnológica para os resíduos sólidos galvânicos}

Visando uma aplicação tecnológica para os resíduos sólidos galvânicos, o procedimento experimental da segunda parte do trabalho envolveu a seleção e coleta de amostras das empresas, a caracterização dos materiais coletados por técnicas analítico-instrumentais e a incorporação dos metais alcalinos e de transição em matrizes vítreas.

\subsubsection{Seleção e coleta dos resíduos sólidos galvânicos para caracterização}

Simultaneamente ao levantamento de dados do questionário, fez-se coleta dos resíduos sólidos por amostragem, em cinco empresas. As empresas de 1 a 5 foram selecionadas, por possuírem os requisitos almejados para 0 estudo, pois as três primeiras empresas atuam exclusivamente com cromação, voltadas ao segmento de metais sanitários, a quarta empresa atua com cromação e niquelação, atendendo o setor de utensílios domésticos e aramados e a quinta empresa possui processo diferenciado, para comparação, porém, utilizando os mesmos banhos principais que as anteriores (banhos de cobre e níquel). Além disto, estas cinco empresas estão distribuídas em grande parte da zona leste ilustrada na FIG. 7, por onde passam rios como o Aricanduva, à beira da Av. Aricanduva, e o Tamunduateí, à beira da Av. do Estado, e outros córregos. 


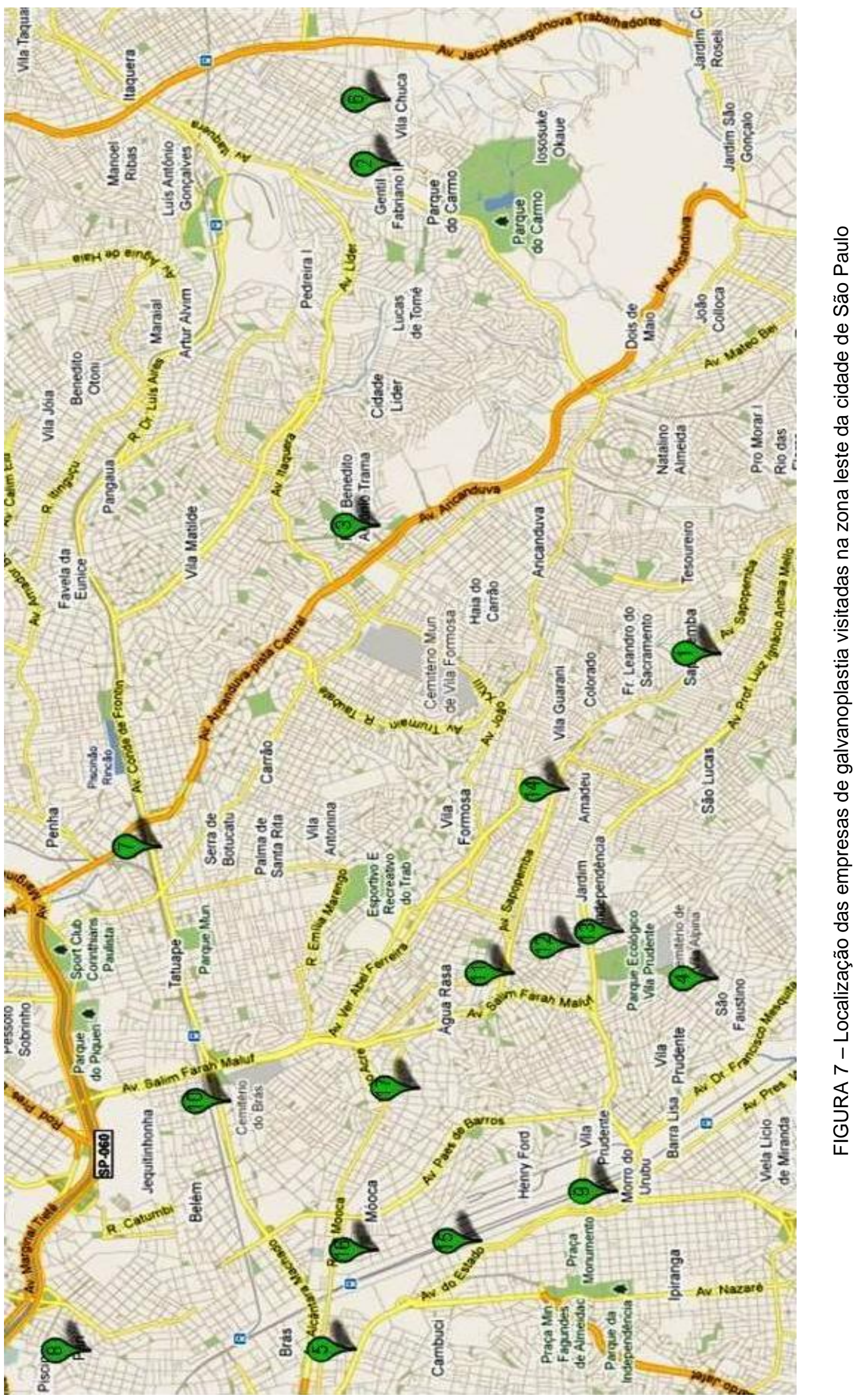


A coleta dos resíduos sólidos foi executada diretamente no leito de secagem, no filtro-prensa ou no tambor de acondicionamento, com auxílio de um saco plástico incolor, retirando-se partes do material aleatoriamente de diferentes pontos, até compor uma quantidade de aproximadamente $5 \mathrm{~kg}$. Em seguida, os materiais foram armazenados em frascos plásticos e identificados por rotulagem, sendo nomeados de acordo com a TAB. 5, onde RSG significa resíduo sólido galvânico.

TABELA 5 - Identificação dos RSGs coletados nas empresas

\begin{tabular}{c|c}
\hline Identificação do material coletado & Característica \\
\hline RSG 1 & Resíduo sólido galvânico da empresa 1 \\
\hline RSG 2 & Resíduo sólido galvânico da empresa 2 \\
\hline RSG 3 & Resíduo sólido galvânico da empresa 3 \\
\hline RSG 4 & Resíduo sólido galvânico da empresa 4 \\
\hline RSG 5 & Resíduo sólido galvânico da empresa 5 \\
\hline
\end{tabular}

\subsubsection{Preparação de amostras e técnicas de caracterização}

A partir dos materiais coletados nas empresas, amostras foram preparadas para a caracterização química e físico-química. Nove técnicas analítico-instrumentais distintas foram utilizadas.

Para a caracterização química, duas técnicas foram utilizadas para a detecção qualitativa dos elementos químicos (FRX e EDS) e quatro técnicas foram utilizadas para a quantificação de seus teores (ICP-AES, FAAS, gravimetria e titulação potenciométrica). Para a caracterização físico-química, três técnicas foram utilizadas para estudar o comportamento dos materiais com o aumento da temperatura (ATD/ATG, DRX e MEV-FEG).

Os materiais foram previamente moídos em moinho de discos oscilantes (tamanho de partícula $<250 \mu \mathrm{m}$ ), para a homogeneização.

Os princípios de cada método, os procedimentos de preparação adotados, os equipamentos utilizados e as condições para as análises estão apresentados a seguir. 


\section{1) Espectrometria de fluorescência de raios $X$ (FRX)}

Nesta técnica, os elementos são excitados por irradiação da amostra com um feixe de raios $X$ ou uma fonte radioativa, pela absorção do feixe primário, e emitem suas linhas características de fluorescência de raios $X^{69}$.

As amostras foram secas a $110^{\circ} \mathrm{C}$ por $24 \mathrm{~h}$, moídas em moinho de discos oscilantes (tamanho de partícula $<75 \mu \mathrm{m}$ ) e acondicionadas em suportes específicos. O equipamento utilizado foi o de marca PHILIPS, modelo PW $2404 \mathrm{e}$ as análises foram realizadas por dispersão de comprimento de onda, com tubo de ródio.

\section{2) Espectrometria de emissão atômica de plasma (ICP-AES)}

As técnicas de espectroscopia atômica utilizam atomizadores para converter os componentes das amostras em átomos ou íons elementares, mas também, neste processo, excitam uma fração destas espécies a elevados estados eletrônicos. A rápida relaxação destas espécies excitadas é acompanhada pela produção de linhas espectrais ultravioleta e visível que são úteis na análise elementar qualitativa e quantitativa ${ }^{69,70}$.

As amostras foram abertas por digestão ácida e, em seguida, foram diluídas em balões volumétricos. O equipamento utilizado foi o de marca VARIAN, modelo VISTA-MPX e as análises foram realizadas com atmosfera de argônio, potência de 1,10 kW, fluxo de plasma de 15,0 L/min, fluxo auxiliar de 1,50 L/min, pressão do nebulizador de $200 \mathrm{kPa}$ e velocidade da bobina de $15 \mathrm{rpm}$.

\section{3) Espectrometria de absorção atômica com chama (FAAS)}

Com base no princípio fundamental desta técnica, o elemento metálico de interesse, no estado atômico de vapor, absorve a radiação de um comprimento de onda específico pela transição de seus elétrons para um nível mais energético. A quantidade de radiação absorvida é diretamente relacionada com a concentração de átomos no estado fundamental, resultando em espectros de emissão atômico, iônico e molecular ${ }^{69}$.

Esta técnica foi utilizada para complementar as análises quantitativas por ICP-AES, por meio da determinação dos teores de sódio e potássio. As amostras foram preparadas por digestão ácida e diluídas em balões volumétricos, para, em seguida, serem analisadas pelo equipamento de marca VARIAN, modelo FS240. As análises foram realizadas com atmosfera de ar 
comprimido/acetileno, fluxo de ar de $11 \mathrm{~L} / \mathrm{min}$, fluxo de acetileno de 1,50 L/min e corrente de $10 \mathrm{~mA}$.

4) Gravimetria

Os métodos gravimétricos se baseiam na determinação da massa de um composto puro ao qual o analito (elemento de interesse) está quimicamente relacionado. Na gravimetria por precipitação, o analito é separado de uma solução da amostra como um precipitado e é convertido a uma espécie de composição conhecida que pode ser pesada ${ }^{71}$.

Esta técnica foi utilizada para complementar as análises quantitativas por ICP-AES, por meio da determinação do teor de enxofre nos RSGs e do teor de óxido de silício nos materiais vítreos. As amostras foram secas a $110^{\circ} \mathrm{C}$ por $24 \mathrm{~h}$ e abertas por digestão ácida. Os equipamentos utilizados foram uma Balança Analítica de marca METTLER TOLEDO, modelo AT261 e uma Mufla de marca BRASIMET, modelo TH2131.

\section{5) Titulação potenciométrica}

Na técnica de titulação, a solução a ser analisada é chamada de analito e a solução de concentração conhecida de reagente é chamada de titulante. O titulante é vertido de uma bureta, no frasco contendo o analito, até que todo o analito tenha reagido (equivalência estequiométrica), determinando, assim, sua concentração. Indicadores (corantes) são utilizados para facilitar a visualização do ponto de equivalência ${ }^{72}$. O ponto final potenciométrico é largamente aplicado e fornece dados inerentemente mais acurados que os métodos correspondentes que usam indicadores ${ }^{71}$.

Esta técnica foi utilizada para complementar as análises quantitativas por ICP-AES, por meio da determinação do teor de cloreto. As amostras foram abertas por digestão ácida e, em seguida, foram diluídas em balões volumétricos. O equipamento utilizado foi o Titulador Potenciométrico Automático de marca METTLER TOLEDO, modelo DL 58 e as análises foram realizadas com eletrodo de prata/cloreto de prata e solução de nitrato de prata 0,05 N como titulante.

6) Análise térmica diferencial e termogravimétrica (ATD e ATG)

Em uma análise termogravimétrica (ATG), a massa de uma amostra em uma atmosfera controlada é registrada continuamente em função do aumento da temperatura, registrando-se reações de decomposição, oxidação, bem como processos físicos como vaporização, sublimação e dessorção. Na análise térmica 
diferencial, a diferença de temperatura entre uma substância e um material de referência é medida em função da temperatura, registrando-se reações de mudanças de fase estrutural, fusões e outras informações relevantes para o material analisado ${ }^{69}$.

As amostras foram secas a $110^{\circ} \mathrm{C}$ por $3 \mathrm{~h}$, moídas em moinho de ágata (tamanho de partícula $<75 \mu \mathrm{m}$ ) e acondicionadas em cadinho de alumina de $110 \mu \mathrm{L}$, sem tampa. O equipamento utilizado foi o de marca TA Instruments, modelo SDT 2960 e as análises foram realizadas com atmosfera de ar sintético, fluxo de $100 \mathrm{~mL} / \mathrm{min}$ e rampa de aquecimento constante de $10^{\circ} \mathrm{C} / \mathrm{min}$ até $1400^{\circ} \mathrm{C}$.

7) Difratometria de raios $X(D R X)$

Os raios $X$ ao atingirem um material podem ser espalhados elasticamente, sem perda de energia pelos elétrons de um átomo (dispersão ou espalhamento coerente). $O$ fóton de raios $X$ após colisão com o elétron muda sua trajetória, mantendo, porém, a mesma fase e energia do fóton incidente. Cada elétron atua, portanto, como centro de emissão de raios $X$. Se os átomos que geram este espalhamento estiverem arranjados de maneira sistemática, apresentando entre eles distâncias próximas ao do comprimento de onda da radiação incidente, pode-se verificar que as relações de fase entre os espalhamentos tornam-se periódicas e que efeitos de difração dos raios $\mathrm{X}$ podem ser observados em vários ângulos. Considerando-se dois ou mais planos de uma estrutura cristalina, as condições para que ocorra a difração de raios $X$ (interferência construtiva ou numa mesma fase) vão depender da diferença de caminho percorrida pelos raios $\mathrm{X}$ e o comprimento de onda da radiação incidente, gerando difratogramas que permitem identificar os compostos cristalinos formados ${ }^{69}$.

Com base nos resultados obtidos nas análises de ATD e ATG, as análises por DRX foram realizadas nas amostras como recebidas e após tratamentos térmicos a $110^{\circ} \mathrm{C}, 600^{\circ} \mathrm{C}, 900^{\circ} \mathrm{C}$ e $1400^{\circ} \mathrm{C}$, após serem moídas em moinho de discos oscilantes (tamanho de partícula $<75 \mu \mathrm{m}$ ), compactadas e acondicionadas em suportes específicos. O equipamento utilizado foi o de marca PANalytical, modelo X'Pert PRO e as análises foram conduzidas com tubo de cobre, corrente de $40 \mathrm{~mA}$, voltagem de $45 \mathrm{kV}$, filtro de radiação $\mathrm{K} \beta$ de níquel, passo de $0,0170^{\circ} 2 \theta$, tempo de $120 \mathrm{~s} /$ passo, sem utilização de monocromador e com a amostra em rotação. 


\section{8) Microscopia eletrônica de varredura por emissão de campo (MEV-FEG)}

O MEV utiliza um feixe colimado de elétrons, que é focalizado por um sistema de três lentes eletromagnéticas. Estes elétrons interagem com a amostra, gerando imagens de sua superfície, que podem ser utilizadas para avaliar a microestrutura dos materiais analisados ${ }^{73}$.

Com base nos resultados obtidos nas análises de ATD e ATG, as análises por MEV-FEG foram realizadas nas amostras como recebidas e após tratamentos térmicos a $110^{\circ} \mathrm{C}, 600^{\circ} \mathrm{C}, 900^{\circ} \mathrm{C}$ e $1400^{\circ} \mathrm{C}$, após serem moídas em moinho de discos oscilantes (tamanho de partícula $<75 \mu \mathrm{m}$ ), afixadas em fitas de carbono adesivas, acondicionadas em suportes específicos e revestidas com carbono, para a condução de corrente. O equipamento utilizado foi o de marca FEI, modelo QUANTA 400F e as análises foram conduzidas sob voltagem de aceleração de $10 \mathrm{kV}$ e $15 \mathrm{kV}$ e detector de imagens de elétrons retroespalhados.

\section{9) Espectrometria de dispersão de energia (EDS)}

A espectrometria de dispersão de energia (EDS) é uma ferramenta dos microscópios eletrônicos de varredura e permite detectar os elementos químicos presentes na amostra analisada. Consiste na interação elétrons-amostra, por meio, geralmente, da ionização das camadas mais internas da eletrosfera, que excitam os elétrons e criam uma vacância, que é ocupada por outro elétron, no processo denominado de relaxamento. Durante este processo, é gerado um fóton, que pode ser convertido em elétrons Auger ou emitir uma energia característica de raios $X(R X$ característico). Para os baixos números atômicos, prevalece a emissão de elétrons Auger e para altos números atômicos, prevalece a emissão de RX característico. Por meio da contagem dos fótons emitidos, tem-se a identificação do elemento analisado, com a formação de um pico de raios $X$ característico $^{73}$.

Primeiramente, esta técnica foi utilizada para complementar as análises qualitativas por $\mathrm{FRX}$, por meio da determinação dos elementos presentes nas amostras como recebidas, com a diferença de detectar os elementos oxigênio e carbono, não detectados por FRX. Posteriormente, foi utilizada para comprovar a presença de elementos em determinadas microestruturas analisadas por DRX e MEV-FEG, após tratamentos térmicos nas amostras. Para as análises, as amostras foram moídas em moinho de discos oscilantes (tamanho de partícula $<75 \mu \mathrm{m})$, afixadas em fitas de carbono adesivas, para a condução de corrente, e 
acondicionadas em suportes específicos. O equipamento utilizado foi o de marca OXFORD, modelo INCAPenta FETx3, acoplado ao MEV-FEG citado acima, e as análises foram realizadas entre $0 \mathrm{keV}$ e $10 \mathrm{keV}$, com modo de parada integral de 500.000 contagens.

\subsubsection{Seleção de amostras para vitrificação}

Entre as possibilidades de valorização dos resíduos sólidos, optou-se pela obtenção de materiais vítreos com a introdução dos resíduos sólidos galvânicos em sua composição, porque estas matrizes podem promover a inertização dos elementos tóxicos e por se tratar de materiais de fácil comercialização e relativamente de baixo custo.

Das amostras caracterizadas, três foram selecionadas para a incorporação de seus constituintes funcionais na estrutura vítrea, a saber: a) RSG 2 - utilizado por apresentar teores intermediários dos principais elementos químicos, inclusive de cromo, em relação às demais amostras; b) RSG 5 utilizado por possuir pequeno teor de cromo e elevado teor de cobre; c) RSG 4 utilizado por apresentar médio teor de cromo em relação ao RSG 2 e ao RSG 5.

\subsubsection{Incorporação dos resíduos sólidos galvânicos em matrizes vítreas}

Visando utilizar os resíduos sólidos em produtos manufaturados capazes de inertizar as substâncias consideradas perigosas e agregar valores aos mesmos, ensaios foram realizados para a incorporação dos RSGs em materiais vítreos. O procedimento experimental adotado está apresentado a seguir.

\subsubsection{Cálculos de composição vítrea}

Baseando-se em estudos anteriores por [SILVA, 2004] $]^{74}$, [SILVA, 2008] ${ }^{75}$ e [MARIALVA, 2003] ${ }^{47}$, optou-se por composições pertencentes ao sistema $\mathrm{Na}_{2} \mathrm{O}-\mathrm{CaO}-\mathrm{SiO}_{2}$, supondo que os metais alcalinos e de transição podem exercer funções semelhantes às dos modificadores, ocupando seu lugar na estrutura.

Calcularam-se as formulações para a obtenção de fritas cerâmicas e vidros silicato do tipo soda-cal, fixando-se a porcentagem de RSGs entre $20 \%$ e $30 \%$ em massa. As composições estudadas foram plotadas no digrama de fases 
ternário do sistema $\mathrm{Na}_{2} \mathrm{O}: \mathrm{CaO}: \mathrm{SiO}_{2}{ }^{76}$ (FIG. 8), estabelecendo identificações específicas de acordo com os principais componentes, conforme TAB. 6, onde 0 "F" foi utilizado para expressar frita e o "V" para expressar vidro. O "R" seguido do número significa o RSG empregado e o número anterior representa sua porcentagem na mistura. O número seguido da letra "N" exprime a porcentagem de $\mathrm{Na}_{2} \mathrm{O}$ e o último número seguido da letra "C" indica a porcentagem de $\mathrm{CaO}$ na mistura. A maioria dos vidros comerciais, como os empregados em janelas, placas ou vidros de contenção, tem suas composições localizadas na área destacada pelo círculo tracejado no diagrama.

TABELA 6 - Identificação das composições para obtenção dos materiais vítreos

\begin{tabular}{c|c|c|c|c}
\hline \multirow{2}{*}{$\begin{array}{c}\text { Identificação da composição no } \\
\text { diagrama de fases }\end{array}$} & \multicolumn{4}{|c}{ Características da mistura } \\
\cline { 2 - 5 } & Produto & RSG & $\mathbf{N a}_{\mathbf{2}} \mathbf{O}$ & $\mathbf{C a O}$ \\
\hline F 27R2 29N 6C & Frita & $27 \%$ de RSG 2 & $29 \%$ & $6 \%$ \\
\hline V 20R2 29N 11C & Vidro & $20 \%$ de RSG 2 & $29 \%$ & $11 \%$ \\
\hline F 24R5 27N 0,5C & Frita & $24 \%$ de RSG 5 & $27 \%$ & $0,5 \%$ \\
\hline V 21R4 21N 5C & Vidro & $21 \%$ de RSG 4 & $21 \%$ & $5 \%$ \\
\hline
\end{tabular}

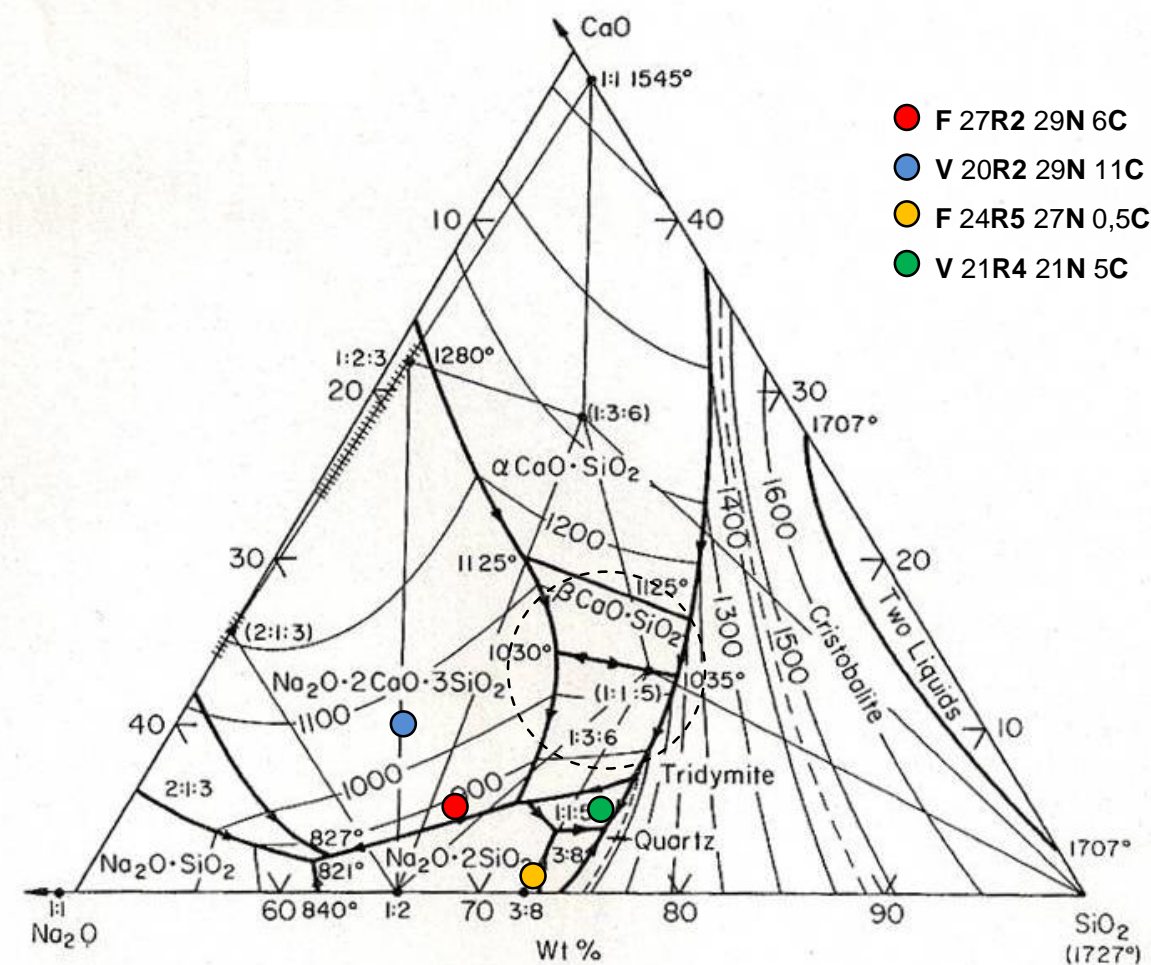

FIGURA 8 - Diagrama de fases do sistema $\mathrm{Na}_{2} \mathrm{O}: \mathrm{CaO}: \mathrm{SiO}_{2}$, indicando as composições estudadas $^{76}$ 


\subsubsection{Preparo das misturas}

As misturas para a obtenção dos materiais vítreos foram preparadas utilizando os compostos e as concentrações apresentadas na TAB. 7.

TABELA 7 - Substâncias utilizadas no preparo das misturas para a obtenção dos materiais vítreos

\begin{tabular}{|c|c|c|}
\hline \multicolumn{2}{|c|}{ Composição da mistura de partida } & \multirow{2}{*}{ Finalidade } \\
\hline Substância & $\%$ em massa & \\
\hline Resíduo (RSG 2) & 27,34 & \multirow{8}{*}{ Obtenção de frita } \\
\hline Sílica $\left(\mathrm{SiO}_{2}\right)$ & 33,16 & \\
\hline Feldspato $\left(71,4 \%\right.$ de $\left.\mathrm{SiO}_{2}\right)$ & 7,21 & \\
\hline Ácido bórico $\left(\mathrm{H}_{3} \mathrm{BO}_{3}\right)$ & 0,03 & \\
\hline Hidróxido de sódio $(\mathrm{NaOH})$ & 26,94 & \\
\hline Óxido de cálcio (CaO) & 4,58 & \\
\hline Carbonato de sódio $\left(\mathrm{Na}_{2} \mathrm{CO}_{3}\right)$ & 0,54 & \\
\hline Alumina $\left(\mathrm{Al}_{2} \mathrm{O}_{3}\right)$ & 0,20 & \\
\hline Resíduo (RSG 2) & 20,01 & \multirow{8}{*}{ Obtenção de vidro } \\
\hline Sílica $\left(\mathrm{SiO}_{2}\right)$ & 33,96 & \\
\hline Feldspato $\left(71,4 \%\right.$ de $\left.\mathrm{SiO}_{2}\right)$ & 7,37 & \\
\hline Ácido bórico $\left(\mathrm{H}_{3} \mathrm{BO}_{3}\right)$ & 0,03 & \\
\hline Hidróxido de sódio $(\mathrm{NaOH})$ & 27,85 & \\
\hline Óxido de cálcio (CaO) & 10,07 & \\
\hline Hidróxido de potássio $(\mathrm{KOH})$ & 0,51 & \\
\hline Alumina $\left(\mathrm{Al}_{2} \mathrm{O}_{3}\right)$ & 0,20 & \\
\hline Resíduo (RSG 5) & 24,43 & \multirow{8}{*}{ Obtenção de frita } \\
\hline Sílica $\left(\mathrm{SiO}_{2}\right)$ & 31,53 & \\
\hline Feldspato $\left(71,4 \%\right.$ de $\left.\mathrm{SiO}_{2}\right)$ & 6,16 & \\
\hline Ácido bórico $\left(\mathrm{H}_{3} \mathrm{BO}_{3}\right)$ & 11,44 & \\
\hline Hidróxido de sódio $(\mathrm{NaOH})$ & 26,01 & \\
\hline Óxido de cálcio $(\mathrm{CaO})$ & 0,03 & \\
\hline Carbonato de potássio $\left(\mathrm{K}_{2} \mathrm{CO}_{3}\right)$ & 0,07 & \\
\hline Alumina $\left(\mathrm{Al}_{2} \mathrm{O}_{3}\right)$ & 0,34 & \\
\hline Resíduo (RSG 4) & 21,00 & \multirow{4}{*}{ Obtenção de vidro } \\
\hline Sílica $\left(\mathrm{SiO}_{2}\right)$ & 56,67 & \\
\hline Carbonato de sódio $\left(\mathrm{Na}_{2} \mathrm{CO}_{3}\right)$ & 21,00 & \\
\hline Alumina $\left(\mathrm{Al}_{2} \mathrm{O}_{3}\right)$ & 1,33 & \\
\hline
\end{tabular}


A maioria dos reagentes utilizados possuía pureza comercial e suas características estão mencionadas a seguir.

A sílica possuía 98,0\% de $\mathrm{SiO}_{2}, 0,9 \%$ de $\mathrm{Al}_{2} \mathrm{O}_{3}, 0,1 \%$ de $\mathrm{CaO}, 0,2 \%$ de $\mathrm{K}_{2} \mathrm{O}, 0,2 \%$ de $\mathrm{Na}_{2} \mathrm{O}, 0,2 \%$ de $\mathrm{Fe}_{2} \mathrm{O}_{3}, 0,1 \%$ de $\mathrm{SO}_{3}$ e $0,3 \%$ de outros elementos. $\mathrm{O}$ feldspato continha $71,4 \%$ de $\mathrm{SiO}_{2}, 16,0 \%$ de $\mathrm{Al}_{2} \mathrm{O}_{3}, 0,6 \%$ de $\mathrm{CaO}, 6,2 \%$ de $\mathrm{K}_{2} \mathrm{O}$, 4,9\% de $\mathrm{Na}_{2} \mathrm{O}, 0,1 \%$ de $\mathrm{MnO}, 0,7 \%$ de $\mathrm{Fe}_{2} \mathrm{O}_{3}$ e $0,1 \%$ de $\mathrm{SO}_{3}$. A pureza do $\mathrm{Na}_{2} \mathrm{CO}_{3}$ era de $95 \%\left(\right.$ Carlo $\mathrm{Erba}^{\circledR}$ ), a do $\mathrm{K}_{2} \mathrm{CO}_{3}$ era de $99 \%$ (Carlo Erba ${ }^{\circledR}$ ), a do $\mathrm{NaOH}$ era de $97 \%$ (Reactif $^{\circledR}$ ), a do $\mathrm{CaO}$ era de $95 \%\left(\right.$ Nuclear $\left.^{\circledR}\right)$, a do $\mathrm{KOH}$ era de $85 \%\left(\right.$ Quimex ${ }^{\circledR}$ ), a do $\mathrm{H}_{3} \mathrm{BO}_{3}$ era de $99,8 \%\left(\right.$ Merck $^{\circledR}$ ) e o $\mathrm{Al}_{2} \mathrm{O}_{3}$ utilizado foi o denominado A-1000 da Alcoa.

As amostras de RSGs, como recebidas, foram secas em estufa a $110^{\circ} \mathrm{C}$ por $24 \mathrm{~h}$ e, posteriormente, desagregadas em moinho de discos oscilantes $(<75 \mu \mathrm{m})$, antes de serem adicionadas à mistura.

Após as formulações, realizou-se a moagem das misturas em almofariz, com pistilo, e as mesmas foram acondicionadas em cadinho de alumina para as fusões.

\subsubsection{Condições de fusão e vertimento}

As fusões foram realizadas em um Forno da marca LINDBERG, modelo Blue $\mathrm{M}$, com atmosfera a ar e aquecimento de $10^{\circ} \mathrm{C} / \mathrm{min}$. As temperaturas de patamar foram de $1300^{\circ} \mathrm{C}$ por $2 \mathrm{~h}$ para as três primeiras composições e de $1500^{\circ} \mathrm{C}$ por $3 \mathrm{~h}$ para a última composição.

Após a fusão, as fritas foram obtidas com o vertimento do fundido em água fria sob agitação. Os vidros foram conformados também por vertimento, mas em moldes prismáticos de aço-carbono com superfície interna polida, medindo $(1 \times 1 \times 3) \mathrm{cm}$. Após a conformação, os vidros foram recozidos a $500^{\circ} \mathrm{C}$, por $3 \mathrm{~h}$.

\subsubsection{Caracterização dos produtos obtidos}

As fritas cerâmicas e os vidros, bem como as águas utilizadas no banho das fritas, foram caracterizados por FRX, ICP e FAAS, para a determinação dos elementos químicos presentes, após passarem pelos mesmos métodos de análise correspondentes já mencionados. 


\section{RESULTADOS E DISCUSSÃO}

De acordo com os métodos adotados para a realização deste trabalho, nos resultados obtidos são apresentados o tratamento dos dados adquiridos nos questionários e os dados experimentais de obtenção dos produtos vítreos com incorporação dos resíduos sólidos galvânicos.

\subsection{Parte A - Resultados obtidos dos questionários aplicados nas empresas de galvanoplastia da zona leste da cidade de São Paulo}

O conjunto de empresas selecionadas forneceu dados relevantes sob seus passivos ambientais e como estes materiais tóxicos podem afetar a região da cidade onde estão inseridas.

\subsubsection{Análise dos dados coletados nas empresas sobre a geração dos resíduos sólidos galvânicos}

O questionário elaborado foi aplicado nas galvanoplastias selecionadas e os principais resultados obtidos, apresentados nas TAB. 8, 9 e 10, mostram um panorama da atuação destas empresas na zona leste da cidade de São Paulo, que é adequado para avaliar a origem dos resíduos sólidos galvânicos de acordo com o processo produtivo, matérias-primas utilizadas e mercados que atendem. Os resultados também assinalam algumas dificuldades encontradas por estas empresas, que são, em sua maioria, de pequeno porte, apresentando deficiências nos controles operacionais e, consequentemente, problemas com a gestão de tais resíduos. Por fim, os resultados mostram uma estimativa da quantidade de resíduos sólidos gerados e como estes são administrados por estas empresas, buscando indicadores dos fatores que influenciam a quantidade gerada e as destinações dadas.

Todas as 17 empresas consultadas possuem Estações de Tratamento de Efluentes (ETEs) e, portanto, geram resíduos sólidos. Pela observação dos dados compilados nas TAB. 8, 9 e 10, nota-se que a maioria das empresas é de pequeno porte e tem o processo de cromação como principal atividade, prestando serviços principalmente para os mercados de metais sanitários e automotivo. Em relação aos resíduos sólidos, a maioria contrata empresas para realizar a destinação, mas os empresários nem sempre sabem o destino final dado. Além disto, todas armazenam os RSGs dentro de suas plantas produtivas e, mesmo 
que destinem, acabam os mantendo estocados por semanas, meses ou anos, em condições precárias, criando um preocupante passivo ambiental que, em caso de acidentes como alagamento ou incêndio, pode afetar a população vizinha, uma vez que estas galvanoplastias localizam-se dentro de um grande centro urbano.

A TAB. 8 apresenta os dados compilados de acordo com os aspectos socioeconômicos, relacionados ao porte da empresa, ao número de funcionários e ao faturamento anual.

TABELA 8 - Principais dados coletados dos questionários - Parte 1 (aspectos socioeconômicos)

\begin{tabular}{c|c|c|c}
\hline Empresa & Porte* & Funcionários & $\begin{array}{c}\text { Faturamento anual } \\
(\mathbf{x} \mathbf{R} \mathbf{\$} \mathbf{1 . 0 0 0 . 0 0 0}, \mathbf{0 0})\end{array}$ \\
\hline 1 & Pequeno & 17 & 0,8 a 1,2 \\
\hline 2 & Pequeno & 56 & 1,2 a 2,4 \\
\hline 3 & Pequeno & 32 & 1,2 a 2,4 \\
\hline 4 & Pequeno & 52 & 1,2 a 2,4 \\
\hline 5 & Pequeno & 44 & 0,4 a 0,8 \\
\hline 6 & Pequeno & 30 & 0,8 a 1,2 \\
\hline 7 & Micro & 11 & 0,1 a 0,4 \\
\hline 8 & Pequeno & 15 & 0,8 a 1,2 \\
\hline 9 & Pequeno & 16 & 0,8 a 1,2 \\
\hline 10 & Médio & 26 & 4,8 \\
\hline 11 & Micro & 17 & 0,0 a 0,1 \\
\hline 12 & Pequeno & 28 & 0,8 a 1,2 \\
\hline 13 & Pequeno & 09 & 0,4 a 0,8 \\
\hline 14 & Pequeno & 18 & 0,4 a 0,8 \\
\hline 15 & Pequeno & 42 & 0,8 a 1,2 \\
\hline 16 & Pequeno & 23 & 0,8 a 1,2 \\
\hline 17 & Pequeno & 18 & 0,1 a 0,4 \\
\hline
\end{tabular}

* Micro empresa: faturamento anual inferior ou igual a $R \$ 240.000,00$ e até 19 funcionários;

Pequena empresa: faturamento anual acima de $R \$ 240.000,00$ e inferior ou igual a $R \$ 2.400 .000,00$ e de 20 a 99 funcionários ${ }^{64}$.

A TAB. 9 apresenta os dados compilados de acordo com os aspectos do processo produtivo, evidenciando o tipo de processo, os substratos utilizados, a quantidade de peças revestidas por mês, o índice de retrabalho e os mercados para os quais as peças são comercializadas. 
TABELA 9 - Principais dados coletados dos questionários - Parte 2 (aspectos do processo produtivo)

\begin{tabular}{|c|c|c|c|c|c|}
\hline Emp. & Processo & $\begin{array}{l}\text { Substratos } \\
\text { utilizados }\end{array}$ & $\begin{array}{l}\text { Peças } \\
\text { revestidas } \\
\text { por mês }\end{array}$ & $\begin{array}{l}\text { Retra- } \\
\text { balho }\end{array}$ & $\begin{array}{c}\text { Principais mercados } \\
\text { de destino }\end{array}$ \\
\hline 1 & Cromação & $\begin{array}{c}\text { Aço-carbono }(50 \%) \\
\text { e latão }(50 \%)\end{array}$ & 300.000 & $0,5 \%$ & Metais sanitários \\
\hline 2 & Cromação & Latão & $20 t$ & $2 \%$ & Metais sanitários \\
\hline 3 & Cromação & $\begin{array}{c}\text { Latão }(90 \%) \text { e aço- } \\
\text { carbono }(10 \%)\end{array}$ & 800.000 & $1 \%$ & Metais sanitários \\
\hline 4 & Cromação e niquelação & Aço-carbono & 100.000 & $3 \%$ & $\begin{array}{l}\text { Utensílios domésticos } \\
\text { e aramados }\end{array}$ \\
\hline 5 & Douração e latonagem & \begin{tabular}{|c|} 
Aço-carbono $(90 \%)$, \\
latão $(10 \%)$ e \\
zamak (irrisório)
\end{tabular} & 45.000 & $1 \%$ & Bijuteria \\
\hline 6 & Cromação & $\begin{array}{l}\text { Latão (100\%) e } \\
\text { alumínio (irrisório) }\end{array}$ & 80.000 & $1 \%$ & Metais sanitários \\
\hline 7 & Cromação & $\begin{array}{c}\text { Aço-carbono (33\%), } \\
\text { alumínio }(33 \%) \text { e } \\
\text { latão }(33 \%)\end{array}$ & $\begin{array}{l}80 \text { rodas e } \\
\text { milhares de } \\
\text { parafusos }\end{array}$ & $1 \%$ & Automotivo \\
\hline 8 & $\begin{array}{l}\text { Cobreação, niquelação, } \\
\text { latonagem e zincagem }\end{array}$ & $\begin{array}{c}\text { Aço-carbono (55\%), } \\
\text { zamak (25\%), latão } \\
\begin{array}{c}(20 \%) \text { e chumbo } \\
\text { (irrisório) }\end{array}\end{array}$ & $30 t$ & $3,5 \%$ & $\begin{array}{l}\text { Aramados, bijuteria, } \\
\text { confecções e chaves }\end{array}$ \\
\hline 9 & Cromação e niquelação & $\begin{array}{c}\text { Aço-carbono }(80 \%) \\
\text { latão }(19 \%) \text { e } \\
\text { zamak }(1 \%)\end{array}$ & 150.000 & $3,5 \%$ & $\begin{array}{c}\text { Instrumentos musicais } \\
\text { e confecções }\end{array}$ \\
\hline 10 & $\begin{array}{l}\text { Cobreação, latonagem, } \\
\text { estanhagem, cadmiação, } \\
\text { zincagem, zinco/níquel, } \\
\text { oxidação negra e } \\
\text { fosfatização }\end{array}$ & $\begin{array}{c}\text { Aço-carbono } \\
(92,5 \%), \text { zamak } \\
(5 \%) \text { e latão }(2,5 \%)\end{array}$ & $200 \mathrm{t}$ & $4 \%$ & $\begin{array}{c}\text { Petroquímico, } \\
\text { automotivo, máquinas, } \\
\text { ferramentas e som }\end{array}$ \\
\hline 11 & Cromação & $\begin{array}{c}\text { Aço-carbono }(50 \%) \\
\text { e latão }(50 \%)\end{array}$ & 100.000 & $5 \%$ & $\begin{array}{l}\text { Metais sanitários, duas } \\
\text { rodas, iluminação e } \\
\text { utensílios domésticos }\end{array}$ \\
\hline 12 & Cromação e latonagem & $\begin{array}{l}\text { Zamak }(70 \%) \text { e } \\
\text { latão }(30 \%)\end{array}$ & 150.000 & $1 \%$ & $\begin{array}{c}\text { Automotivo, metais } \\
\text { sanitários, iluminação } \\
\text { e utensílios } \\
\text { domésticos }\end{array}$ \\
\hline 13 & $\begin{array}{l}\text { Niquelação, latonagem, } \\
\text { estanhagem e zincagem }\end{array}$ & $\begin{array}{c}\text { Zamak }(60 \%) \text { e aço- } \\
\text { carbono }(40 \%)\end{array}$ & $12 t$ & $2 \%$ & $\begin{array}{c}\text { Automotivo e } \\
\text { confecções }\end{array}$ \\
\hline 14 & Cromação e zincagem & $\begin{array}{c}\text { Aço-carbono }(90 \%) \\
\text { e zamak }(10 \%)\end{array}$ & $70 t$ & $3 \%$ & $\begin{array}{c}\text { Construção civil, } \\
\text { aramados e metais } \\
\text { sanitários }\end{array}$ \\
\hline 15 & $\begin{array}{l}\text { Cromação, niquelação, } \\
\text { latonagem e douração }\end{array}$ & $\begin{array}{c}\text { ABS }(95 \%) \text { e zamak } \\
(5 \%)\end{array}$ & 800.000 & $8 \%$ & $\begin{array}{l}\text { Eletrônico, automotivo, } \\
\text { confecções, aramados } \\
\text { e metais sanitários }\end{array}$ \\
\hline 16 & Douração e prateação & $\begin{array}{l}\text { Latão }(80 \%) \text { e liga } \\
\text { SnPb }(20 \%)\end{array}$ & $0,5 \mathrm{t}$ & $0,5 \%$ & Bijuteria \\
\hline 17 & $\begin{array}{c}\text { Cromação, niquelação e } \\
\text { cobreação }\end{array}$ & ABS & 130.000 & $2 \%$ & $\begin{array}{c}\text { Metais sanitários e } \\
\text { automotivo }\end{array}$ \\
\hline
\end{tabular}


$\mathrm{Na}$ TAB. 10, os dados estão agrupados de acordo com as características dos resíduos sólidos gerados, mostrando a forma de secagem, a quantidade de resíduo gerado, o tipo de acondicionamento, o tempo de armazenagem até a destinação e a destinação propriamente dita, indicando a empresa responsável pela coleta e o destino final provável do resíduo.

TABELA 10 - Principais dados coletados dos questionários - Parte 3 (aspectos sobre os resíduos sólidos galvânicos gerados)

\begin{tabular}{|c|c|c|c|c|c|c|}
\hline \multirow[b]{2}{*}{ Emp. } & \multirow[b]{2}{*}{$\begin{array}{l}\text { Secagem do } \\
\text { RSG }\end{array}$} & \multirow[b]{2}{*}{$\begin{array}{r}\text { Qtde de } \\
\text { RSG/ano }\end{array}$} & \multirow{2}{*}{$\begin{array}{c}\text { Acondicionamento } \\
\text { do RSG }\end{array}$} & \multirow{2}{*}{\begin{tabular}{|c|} 
Tempo de \\
armazenagem \\
do RSG antes \\
da destinação
\end{tabular}} & \multicolumn{2}{|c|}{ Destinação do RSG } \\
\hline & & & & & $\begin{array}{l}\text { Empresa } \\
\text { de coleta }\end{array}$ & $\begin{array}{l}\text { Destino final } \\
\text { informado }\end{array}$ \\
\hline 1 & Filtro-prensa & $1,8 \mathrm{t}$ & Tambor de aço & \multirow{2}{*}{\begin{tabular}{|c|} 
Indeterminado \\
(não destina)
\end{tabular}} & \multirow{2}{*}{ Não há } & \multirow{2}{*}{ Não há } \\
\hline 2 & Leito de secagem & $0,4 \mathrm{t}$ & Sacos plásticos & & & \\
\hline 3 & \multirow{2}{*}{ Filtro-prensa } & $5 \mathrm{t}$ & \multirow{2}{*}{$\begin{array}{l}\text { Tambor de aço com } \\
\text { saco plástico }\end{array}$} & 3 a 4 meses & $A$ & Desconhece \\
\hline 4 & & $16 t$ & & 6 meses & $B$ & Incineração \\
\hline 5 & Bacias plásticas & $0,03 \mathrm{t}$ & Tambor de aço & $\begin{array}{c}\text { Indeterminado } \\
\text { (não destina) }\end{array}$ & Não há & Não há \\
\hline 6 & \multirow{2}{*}{ Leito de secagem } & $0,8 \mathrm{t}$ & \multirow{12}{*}{$\begin{array}{c}\text { Tambor de aço com } \\
\text { saco plástico }\end{array}$} & 4 anos & \multirow{3}{*}{ C } & Desconhece \\
\hline 7 & & $2,5 \mathrm{t}$ & & 5 meses & & Setor cerâmico \\
\hline 8 & Filtro-prensa & $1,8 \mathrm{t}$ & & 2 anos & & $\begin{array}{l}\text { Micronutrientes } \\
\text { para agricultura }\end{array}$ \\
\hline 9 & Leito de secagem & $10 t$ & & 15 dias & A & $\begin{array}{c}\text { Transformação } \\
\text { em lingote } \\
\text { metálico }\end{array}$ \\
\hline 10 & \multirow[t]{2}{*}{ Filtro-prensa } & $50 \mathrm{t}$ & & 7 dias & C & $\begin{array}{l}\text { Micronutrientes } \\
\text { para agricultura }\end{array}$ \\
\hline 11 & & $0,6 \mathrm{t}$ & & 2 anos & A & Incineração \\
\hline 12 & \multirow{5}{*}{ Leito de secagem } & $1,5 \mathrm{t}$ & & 3 meses & C & $\begin{array}{l}\text { Micronutrientes } \\
\text { para agricultura }\end{array}$ \\
\hline 13 & & $1 \mathrm{t}$ & & \begin{tabular}{|c|} 
Indeterminado \\
(não destina)
\end{tabular} & Não há & Não há \\
\hline 14 & & $2 t$ & & 1,5 mês & \multirow{2}{*}{ C } & \multirow{3}{*}{ Desconhece } \\
\hline 15 & & $4 t$ & & \multirow{2}{*}{1 ano } & & \\
\hline 16 & & $0,2 \mathrm{t}$ & & & Não há* & \\
\hline 17 & Filtro-prensa & $8 t$ & & 3 meses & C & Aterro \\
\hline
\end{tabular}

De acordo com os resultados obtidos, observa-se que as 17 empresas de galvanoplastia consultadas geram aproximadamente 106 toneladas de 
resíduos sólidos por ano, totalizando uma média aritmética de aproximadamente seis toneladas de RSGs por ano, por empresa. Extrapolando a soma total para o universo de aproximadamente 30 empresas de cromação atendidas pelo PRUMO/TS na zona leste da cidade de São Paulo, estima-se que são geradas cerca de 190 toneladas de RSGs por ano, conforme TAB. 11. Não é possível estabelecer exatamente o valor total de RSGs gerados nas cromações da zona leste da cidade de São Paulo, pois não se sabe ao certo o número de empresas existentes, porém, este valor demonstra uma ordem de grandeza para o setor nesta região, levando em conta que o PRUMO/TS atendeu grande parte destas empresas na zona leste.

TABELA 11 - Quantidade de resíduos sólidos gerados por ano nas empresas

\begin{tabular}{c|c}
\hline Parâmetro estudado & $\begin{array}{c}\text { Resíduos sólidos } \\
\text { gerados por ano }\end{array}$ \\
\hline Valor total das 17 empresas consultadas & $106 \mathrm{t}$ \\
\hline Valor médio gerado por cada empresa & $6 \mathrm{t}$ \\
\hline Valor total estimado para 30 empresas atendidas pelo PRUMO/TS & $190 \mathrm{t}$ \\
\hline
\end{tabular}

Conforme os dados mencionados anteriormente nas TAB. 4 e 5, havia em 2005, respectivamente, 2.195 e 4.577 galvanoplastias no Estado de São Paulo e no Brasil, e se o valor pudesse ser extrapolado para estes totais, seriam geradas aproximadamente 13.700 e 28.500 toneladas de RSGs por ano, sendo muito menores que os valores genéricos anteriormente divulgados, que eram de 50.000 toneladas em $1998^{17}$ e de 150.000 a 200.000 em $2007^{18}$. Apesar destas referências bibliográficas não apresentarem os critérios adotados para 0 levantamento destas quantidades, não se pode realizar tal extrapolação, pois os valores levantados neste trabalho são válidos somente para cromações e voltados para as empresas de micro e pequeno porte. É provável que a quantidade de resíduos sólidos gerados em todas as galvanoplastias (cromações, zincagens, cadmiação, estanhagem, prateação e outras) seja muito maior.

Segundo dados da literatura, um estudo realizado no ano de 2000 pelo SENAI-RS ${ }^{77}$ mostra que, em 56 empresas de tratamento de superfícies contatadas no Rio Grande do Sul, eram geradas aproximadamente de 500 a 1.500 toneladas de resíduos sólidos por ano, considerando empresas de todos os segmentos de tratamento de superfícies e de todos os portes. Estes valores 
resultam numa média aritmética de 9 a 27 toneladas de resíduos sólidos gerados por ano por empresa, enquanto os dados coletados nas 17 galvanoplastias (cromações) contatadas na zona leste do município de São Paulo resultam numa média aritmética de seis toneladas de resíduos sólidos gerados por ano por empresa, conforme TAB. 11.

Deve ser considerado, que no estudo realizado pelo SENAI-RS, das 56 empresas contatadas, somente 27 exerciam exclusivamente atividades de galvanoplastia, 11 exerciam outras atividades como pintura e fosfatização e 18 exerciam somente pintura e fosfatização, influenciando na quantidade de resíduos sólidos gerados, provavelmente, para um valor maior. Porém, para efeito de comparação, o valor mínimo de nove toneladas de RSGs por ano por empresa se aproxima do valor de seis toneladas de RSGs por ano por empresa, obtido neste trabalho.

Para as 17 galvanoplastias visitadas, a distribuição da porcentagem de empresas de acordo com a quantidade de resíduos sólidos gerados por ano está apresentada na FIG. 9. Observa-se que a maioria não chega a gerar uma tonelada por ano e mais da metade gera até duas toneladas por ano. Isto se deve ao fato de serem empresas de micro e pequeno porte, conforme FIG. 10.

As micro e pequenas empresas geram uma quantidade bem menor de resíduos sólidos em relação às médias e grandes empresas, mas como existem muitas micro e pequenas empresas, a soma dos RSGs gerados é preocupante.
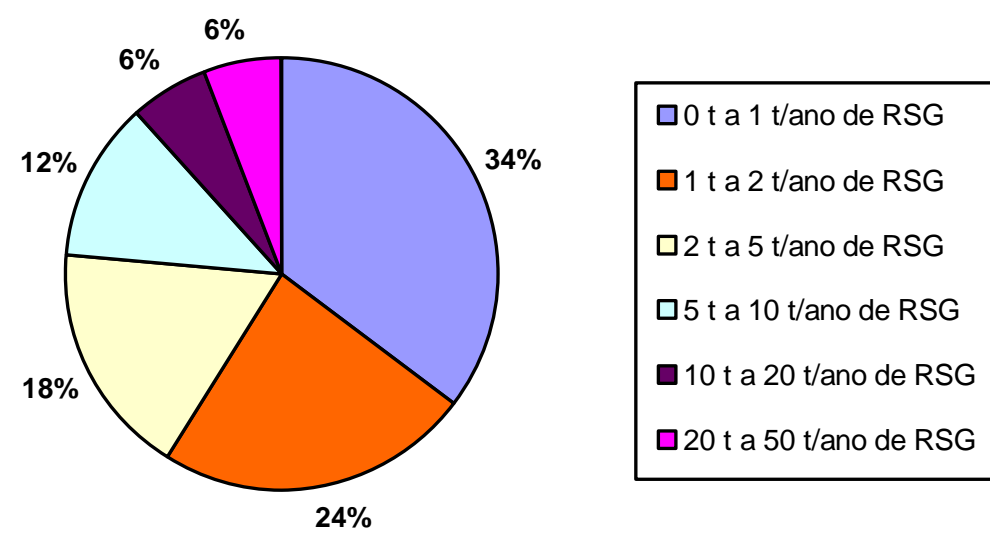

FIGURA 9 -Distribuição da porcentagem de empresas de acordo com a quantidade de lodo gerado por ano 


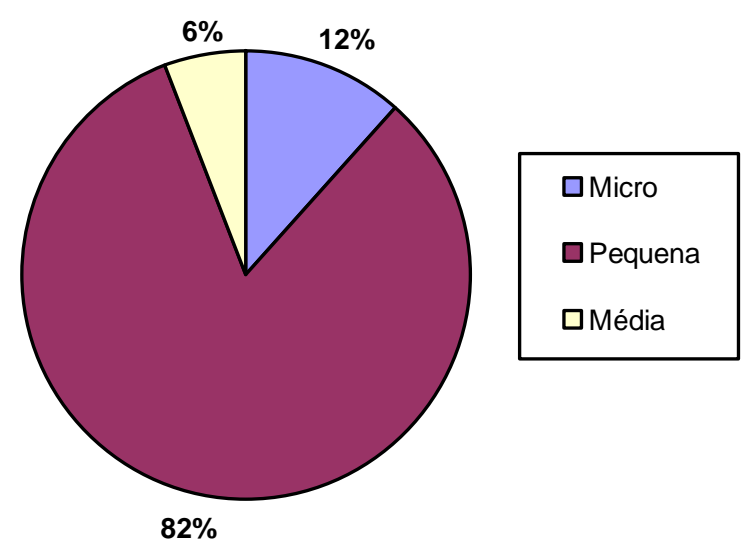

FIGURA 10 - Porcentagem de micro, pequenas e médias empresas (MPMEs) visitadas

As empresas de médio e grande porte, por sua vez, geram individualmente uma quantidade muito maior de resíduos sólidos, mas são encontradas em menor número. Existem algumas empresas de galvanoplastia de médio porte, mas não se tem conhecimento da existência de empresas de grande porte na zona leste da cidade de São Paulo e na cidade de São Paulo. A empresa $\mathrm{n}^{\circ} 10$, que é de médio porte, é um exemplo da disparidade da quantidade de resíduos sólidos gerados. Nesta empresa, são geradas 50 toneladas de resíduos sólidos por ano, conforme TAB. 10, sendo praticamente 14 vezes maior que a média aritmética da quantidade de resíduos sólidos gerados nas empresas de micro e pequeno porte, que é de 3,5 toneladas. Este valor também é praticamente três vezes maior que a quantidade de resíduos sólidos gerados pela empresa $\mathrm{n}^{\circ} 4$, que, entre as empresas de micro e pequeno porte, é a que gera a maior quantidade de RSGs por ano (16 toneladas), conforme TAB. 12. Esta empresa gera, individualmente, praticamente a mesma quantidade de RSGs da soma das outras 16 empresas.

TABELA 12 - Resíduos sólidos gerados nas empresas de médio porte em relação às empresas de micro e pequeno porte

\begin{tabular}{c|c}
\hline Parâmetro estudado & $\begin{array}{c}\text { Resíduos sólidos gerados } \\
\text { por ano }\end{array}$ \\
\hline Empresa de médio porte (Empresa $\left.n^{\circ}{ }^{10}\right)$ & $50 \mathrm{t}$ \\
\hline Valor médio entre as micro e pequenas empresas & $3,5 \mathrm{t}$ \\
\hline $\begin{array}{c}\text { Empresa que mais gera resíduos sólidos entre as micro e } \\
\text { pequenas empresas (Empresa } \mathrm{n}^{\circ} \text { 4) }\end{array}$ & $16 \mathrm{t}$ \\
\hline
\end{tabular}


A quantidade de RSGs gerados é dependente do tipo do processo produtivo, dos substratos utilizados e da quantidade de peças revestidas, além do índice de retrabalho.

Com base nos dados coletados, a FIG. 11 evidencia que das 17 empresas contatadas, 12 exercem atividades de cromação e todas, exceto a empresa $n^{\circ} 16$, que exerce exclusivamente atividades de douração e prateação, exercem atividades correlacionadas, como niquelação, cobreação e latonagem, utilizando os mesmos substratos e banhos da cromação (exceto banho de cromo) e estando voltadas aos mesmos mercados. Nota-se que a maioria exerce mais de um tipo de atividade, mostrando a correlação entre estas.

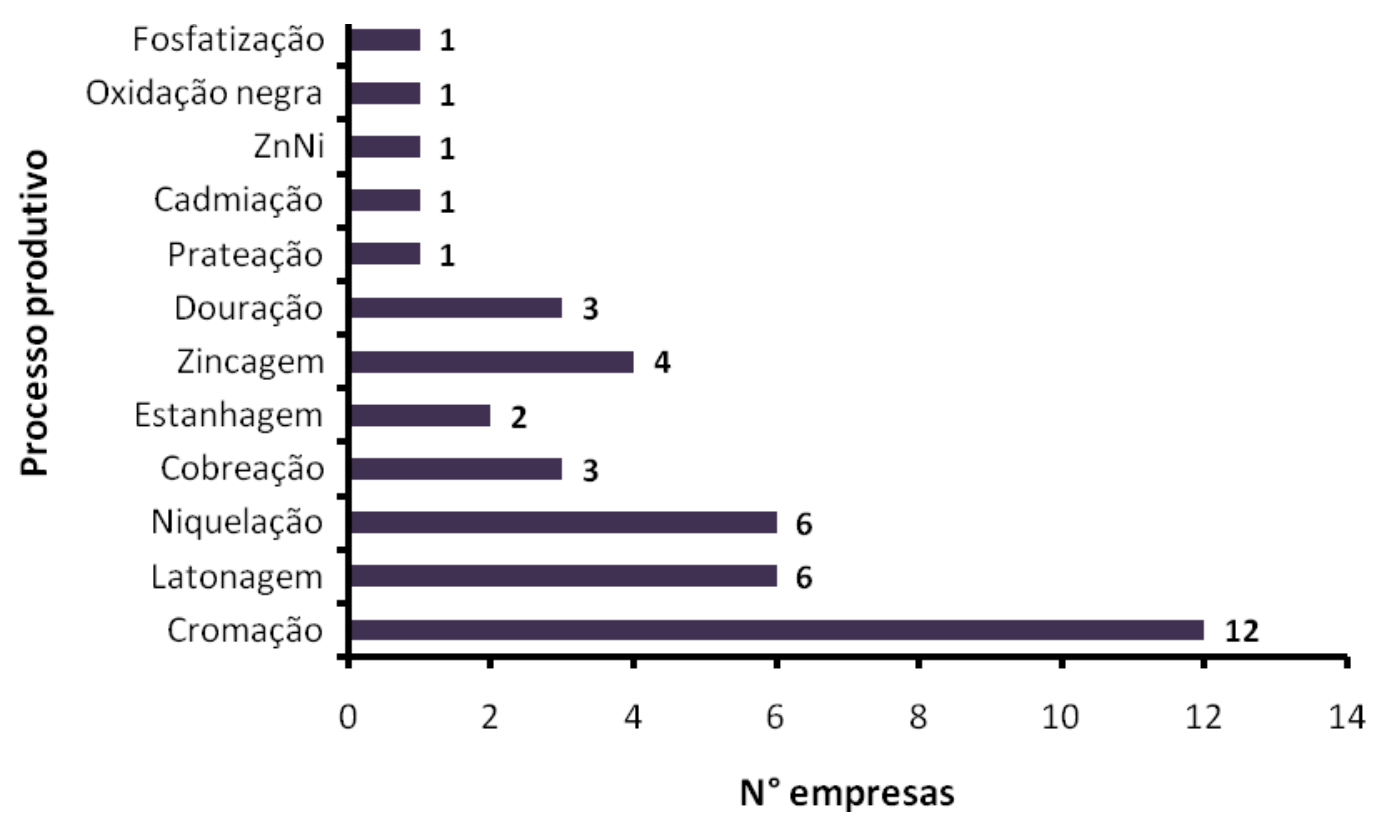

FIGURA 11 - Distribuição do número de empresas de acordo com as atividades exercidas

Os substratos mais utilizados são o aço-carbono (liga de ferro-carbono, com $0 \%$ a $2 \%$ de carbono) e o latão (liga de cobre-zinco, com $5 \%$ a $50 \%$ de zinco), conforme FIG. 12. Nota-se que as empresas utilizam mais de um substrato. Apesar dos metais presentes nos substratos exercerem a função de catodo no sistema eletrolítico, recebendo o revestimento, estes se dissolvem em pequenas quantidades nos pré-tratamentos e nos banhos, sendo direcionados para a ETE e fazendo parte dos resíduos sólidos. Os substratos geralmente são enviados pelos clientes e, desta forma, as empresas de galvanoplastia não 
produzem peças próprias, pois somente prestam serviços de tratamento de superfícies.

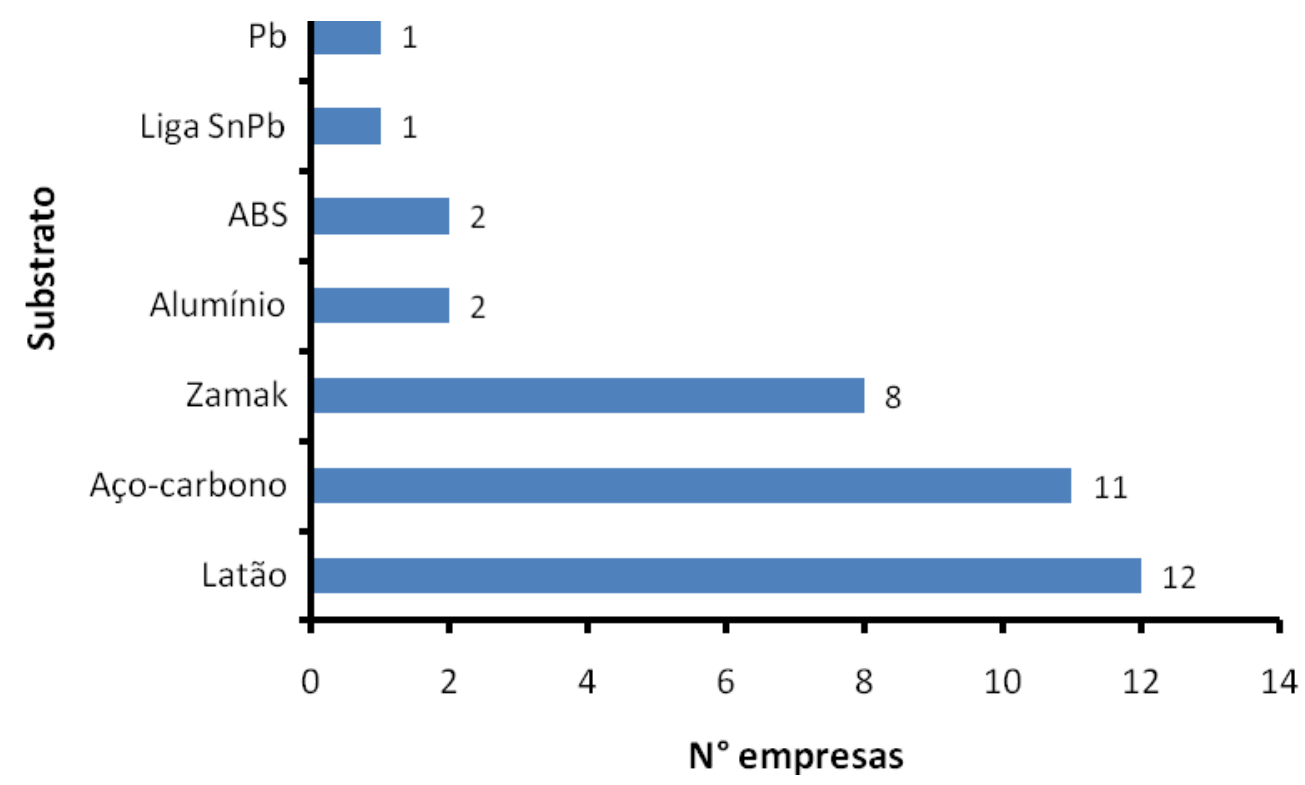

FIGURA 12 - Distribuição do número de empresas de acordo com o substrato utilizado

A quantidade de peças revestidas por mês é um dos principais fatores que influencia a geração dos resíduos sólidos, porém, é preciso esclarecer uma problemática enfrentada pelas empresas. A eletrodeposição ocorre pela incidência da corrente em uma quantidade de área, denominada de densidade de corrente (i), expressa em ampère por decímetro quadrado $\left(A / \mathrm{dm}^{2}\right)$, que determina a espessura do revestimento a ser depositado e, consequentemente, a quantidade de banho consumido. Sendo assim, o que importa é a área de peças a ser revestida e não a quantidade de peças. No entanto, as empresas geralmente não controlam a área, devido à geometria das peças ser muito variada. Isto implica na não possibilidade de correlação entre a quantidade de peças revestidas e a quantidade de resíduos sólidos gerados. Um exemplo disto pode ser observado ao se comparar os valores apresentados pela empresa $n^{\circ} 1$ com a empresa $n^{\circ} 4$. Na empresa $n^{\circ} 1$, são revestidas 300.000 peças por mês e é gerada $1,8 \mathrm{t}$ de resíduos sólidos por ano, enquanto na empresa $n^{\circ} 4$, são revestidas 100.000 peças por mês e são geradas $16 \mathrm{t}$ de resíduos sólidos por ano. A empresa $n^{\circ} 4$ reveste muitos escorredores de prato e a empresa $n^{\circ} 1$ reveste muitas torneiras, canoplas e volantes. A área de um escorredor de pratos é muito maior que a de uma torneira. Sendo assim, se gasta muito mais matéria- 
prima (são consumidos muito mais sais dos banhos) num escorredor de pratos do que numa torneira, gerando uma maior quantidade de efluentes para tratar e, consequentemente, uma maior quantidade de resíduos sólidos no final. Mesmo com esta particularidade, as quantidades ou massas de peças revestidas por mês foram levantadas e observa-se que a maioria reveste entre 0 e 100.000 peças por mês e entre 100.000 e 200.000 peças por mês, conforme FIG. 13.

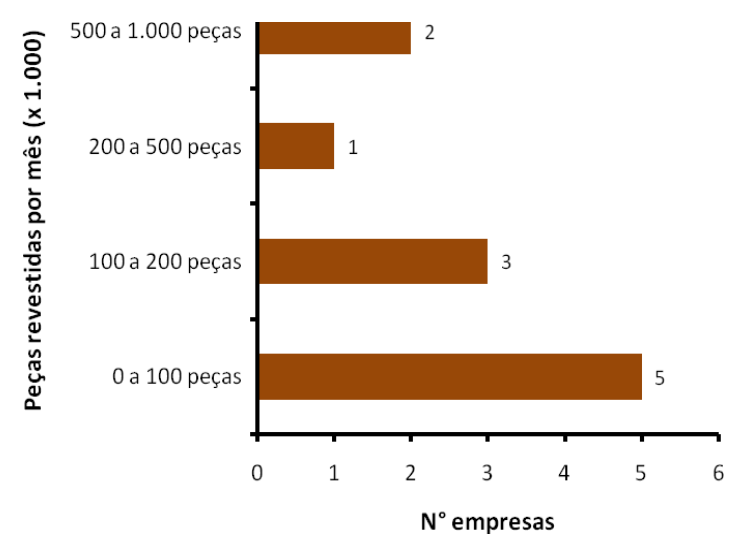

a)

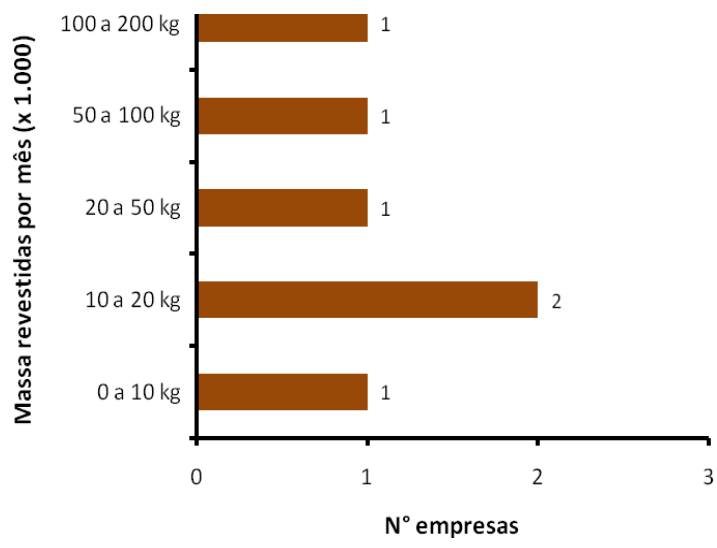

b)

FIGURA 13 - Distribuição do número de empresas de acordo com a quantidade ou massa de peças revestidas por mês: a) de acordo com a quantidade e b) de acordo com a massa

O retrabalho é outro fator que influencia a quantidade de resíduos sólidos gerados, pois as peças revestidas novamente, por algum problema estético, passam por todas as etapas do processo galvânico, aumentando a quantidade de resíduos gerados. Sendo assim, estes valores foram extraídos dos questionários e observa-se que a maioria apresenta índices entre 0\% e 2,5\% do volume da produção, conforme FIG. 14.

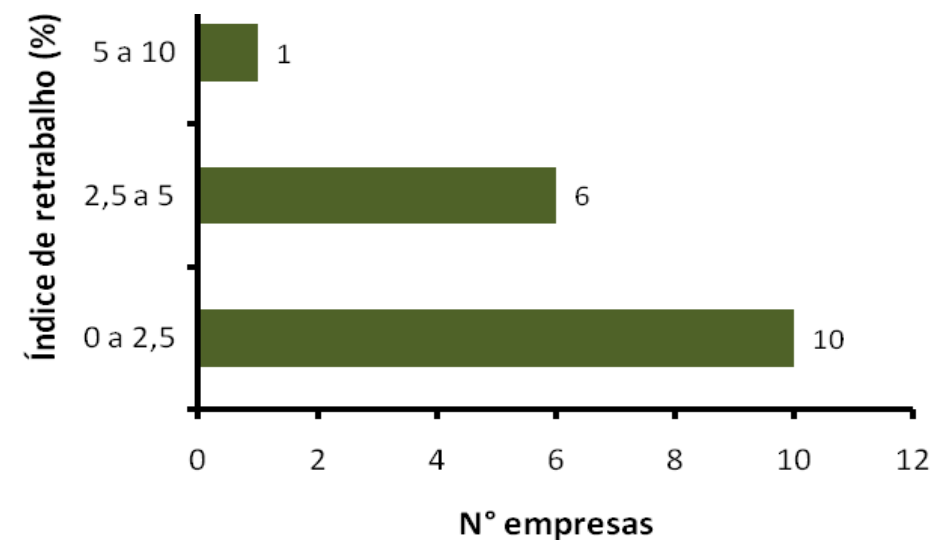

FIGURA 14 - Distribuição do número de empresas de acordo com o índice de retrabalho 
O fato de praticamente todas as empresas visitadas serem de micro e pequeno porte, indica que as mesmas enfrentam, em alguns casos, dificuldades financeiras, afetando a sua forma de gerir os resíduos sólidos. Mesmo não havendo dificuldades financeiras, as empresas, em geral, no Brasil ainda tratam seus resíduos como "lixo" e não como fonte de renda ou como oportunidade para gerar novos produtos, diminuindo, assim, a poluição ambiental. Este fato pôde ser observado na maioria das empresas visitadas, pois destinam o resíduo por obrigação da lei, sendo que algumas sequer destinam. Empresas de soluções ambientais são contratadas para realizar a destinação, conforme FIG. 15, mas muitas das galvanoplastias não sabem o real destino final de seus resíduos ou, no questionário, indicaram um destino final que a empresa de solução ambiental não realiza, demonstrando uma despreocupação com esta questão, conforme FIG. 16.

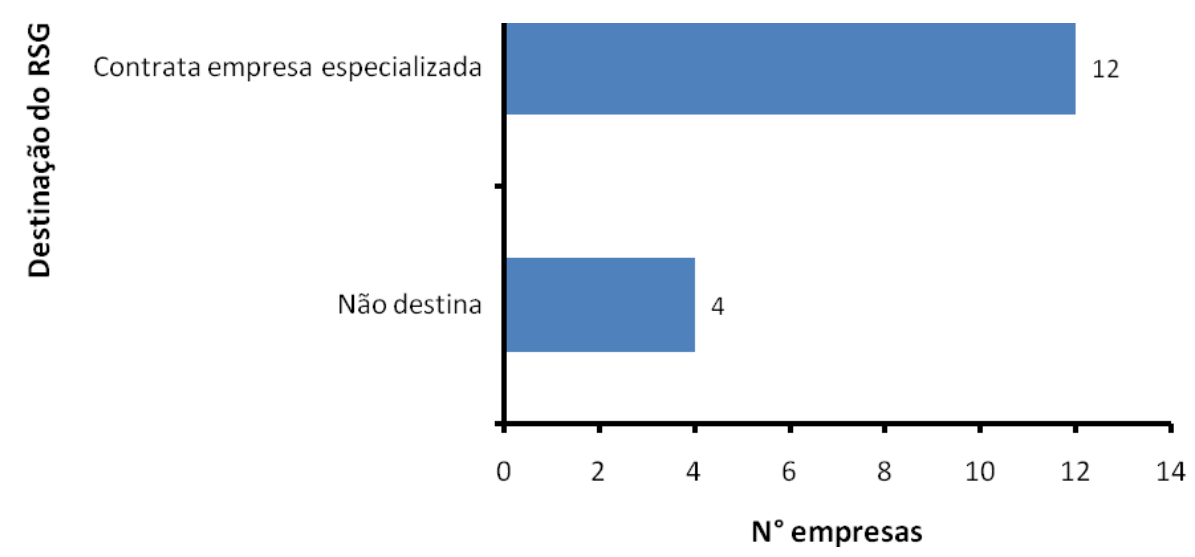

FIGURA 15 - Distribuição do número de empresas de acordo com as destinações dos RSGs

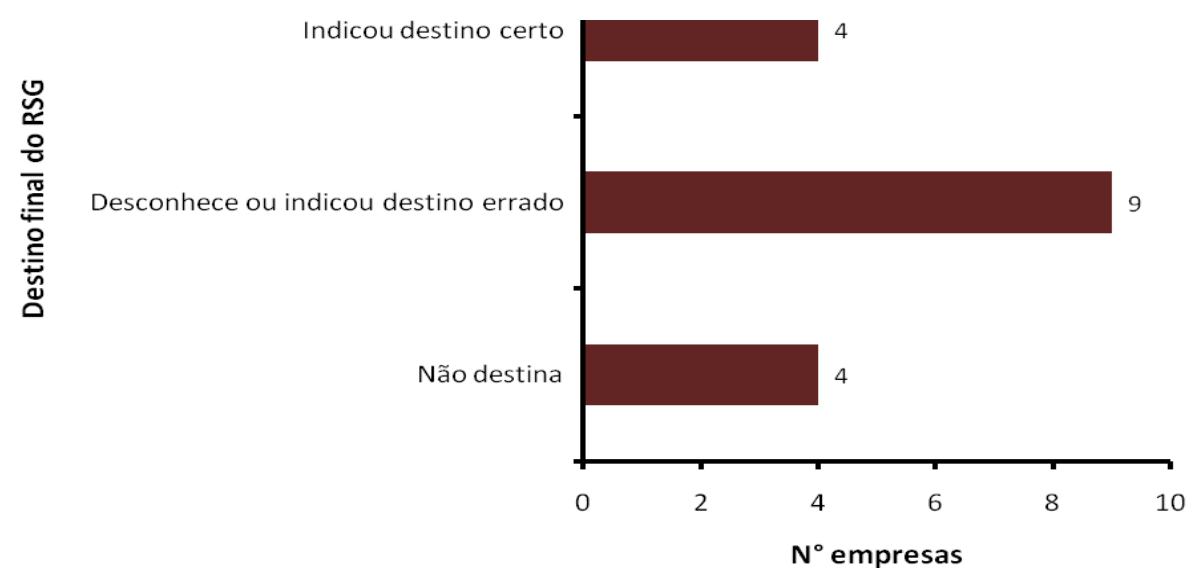

FIGURA 16 - Distribuição do número de empresas de acordo com o destino final dos RSGs 
A maioria das empresas destina os resíduos sólidos para a empresa Centralsuper Comércio de Produtos Químicos Ltda, conforme FIG. 17, que foi criada por empresários ligados ao SINDISUPER. Nesta empresa, os RSGs são enviados para a cidade de Catalão, em Goiás, para a transformação em micronutrientes de solos pela empresa Hebert \& Hegert Johanssen Recuperados de Resíduos Ltda e não são enviados para o setor cerâmico ou para aterro, conforme mencionado pelas empresas $n^{\circ} 7$ e 17, respectivamente. A empresa Ecológica Nova Era Indústria e Comércio Ltda transforma os RSGs em lingotes metálicos, que voltam à cadeia produtiva, e não envia para a incineração, como informado pela empresa $\mathrm{n}^{\circ}$ 11. A empresa Suzaquim Indústria Química Ltda transforma os RSGs em sais e óxidos metálicos, que são utilizados em indústrias de vidro, tintas, cerâmicas e indústrias químicas em geral, e não envia para a incineração, como informado pela empresa $n^{\circ} 4$.

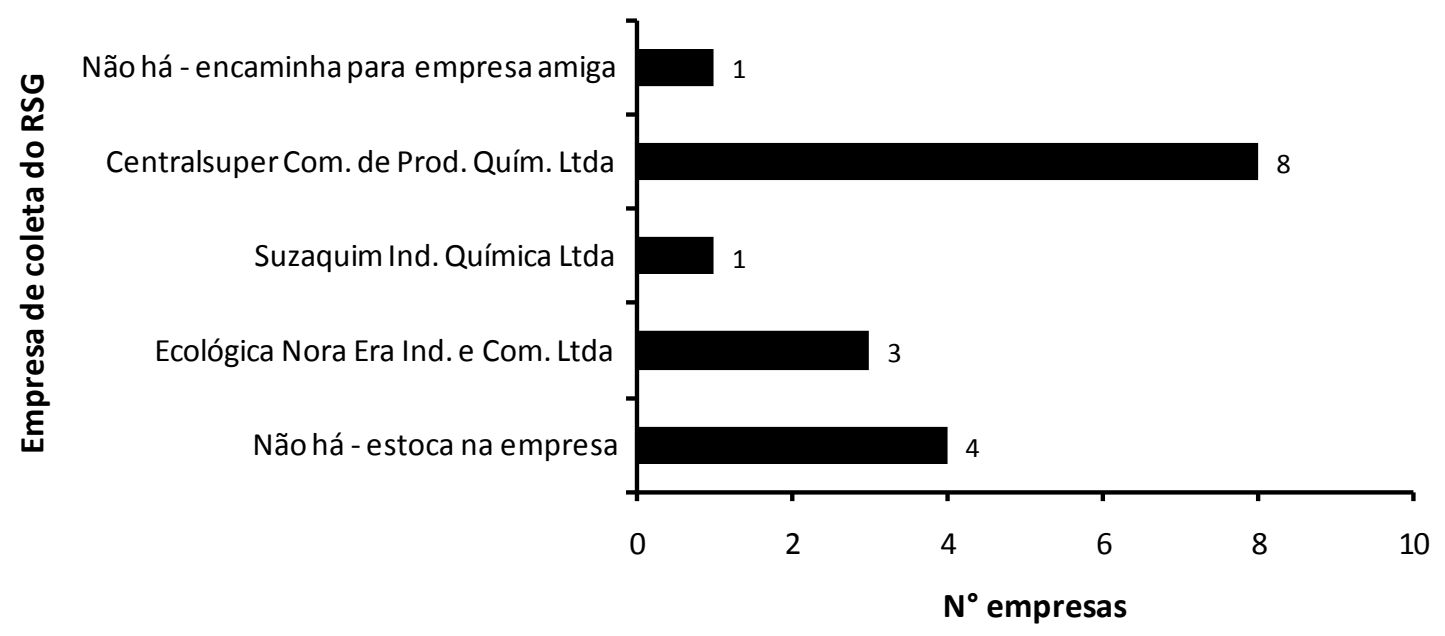

FIGURA 17 - Distribuição do número de empresas de acordo com as empresas de coleta dos RSGs

O acondicionamento dos RSGs desperta outra preocupação. Os órgãos regulamentadores, como a CETESB, exigem que o acondicionamento dos resíduos sólidos siga critérios de forma a proteger a saúde pública e o meio ambiente. Deve haver uma área de contenção; o armazenamento deve ser realizado dentro de sacos plásticos e tambores; os sacos plásticos e os tambores devem ter características específicas para resistir quimicamente ao resíduo; os sacos plásticos e tambores não devem estar danificados e devem ser lacrados; o tambor deve ser rotulado, identificando a empresa, o tipo de processo produtivo, o procedimento de tratamento de efluentes, a origem do resíduo, além de outras 
exigências. A norma ABNT NBR 12235:1992 ${ }^{78}$ fixa as condições exigíveis para o armazenamento de resíduos sólidos perigosos. No entanto, muitas vezes estas exigências não são seguidas e os resíduos sólidos tornam-se substâncias nocivas em caso de vazamentos ou acidentes como enxurradas ou incêndios.

Foram feitos alguns registros fotográficos nas empresas visitadas e estes demonstram a precariedade das armazenagens. Na FIG. 18, pode ser notado que há uma área de contenção, porém, o RSG está acondicionado diretamente dentro de um tambor de aço, sem a presença de saco plástico para proteger as paredes internas do tambor. Na FIG. 19, os RSGs também estão corretamente dentro de uma área de contenção, porém, estão acondicionados somente em sacos plásticos. Na FIG. 20, é possível notar um leito de secagem em condições precárias e na FIG. 21, encontra-se a forma correta de acondicionamento, porém, foi possível comprovar que estava sem rotulagem. As formas de acondiocionamento realizadas por todas as empresas contatadas estão apresentadas na FIG. 22. Durante as visitas, foi possível observar que a maioria acondiciona corretamente em sacos plásticos e em tambores de aço de $250 \mathrm{~L}$, porém, sem identificação, por meio de rotulagem, e sem áreas de contenção, em alguns casos.

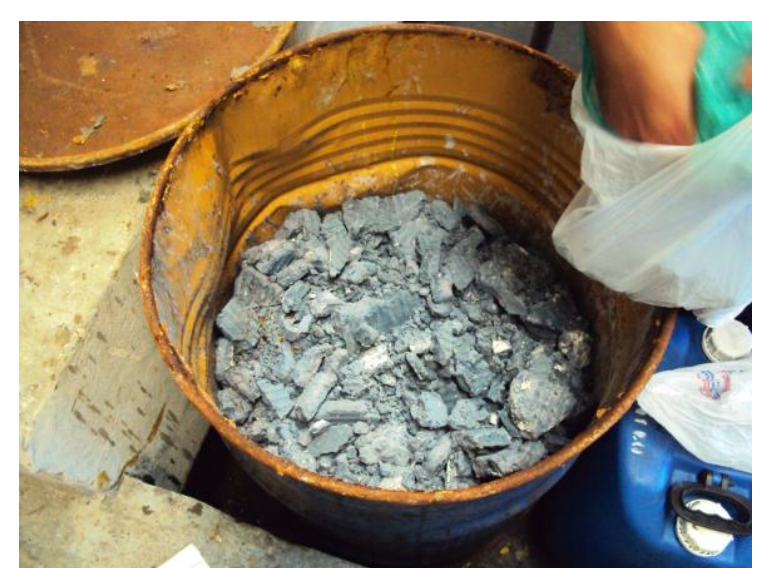

FIGURA 18 - Acondicionamento de lodo em tambor, sem plástico

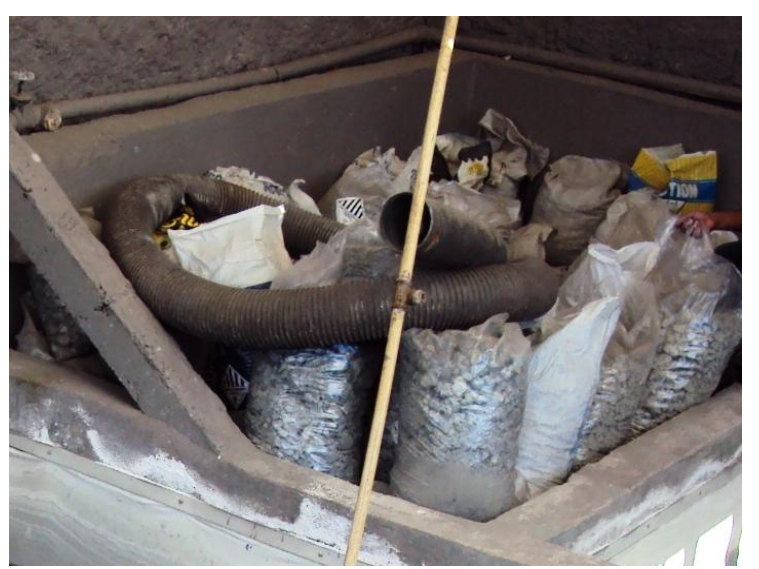

FIGURA 19 - Acondicionamento de lodo em sacos plásticos, fora de tambor 


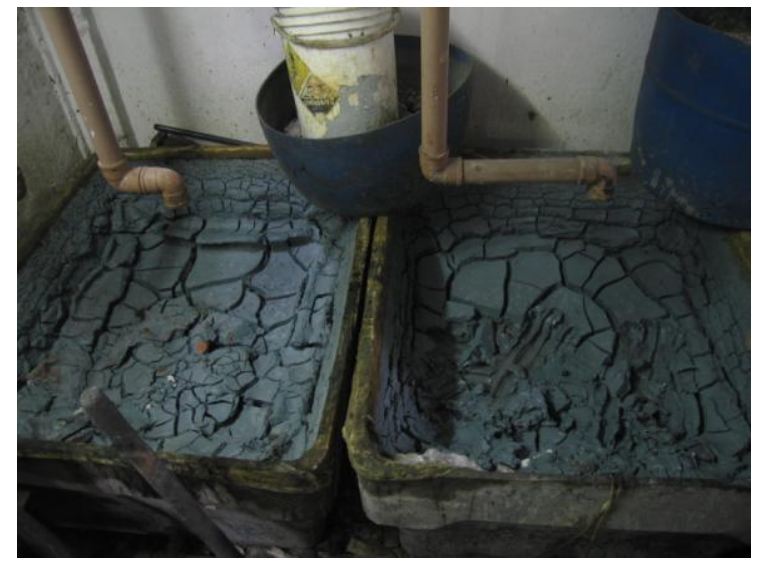

FIGURA 20 - Leito de secagem em condições precárias

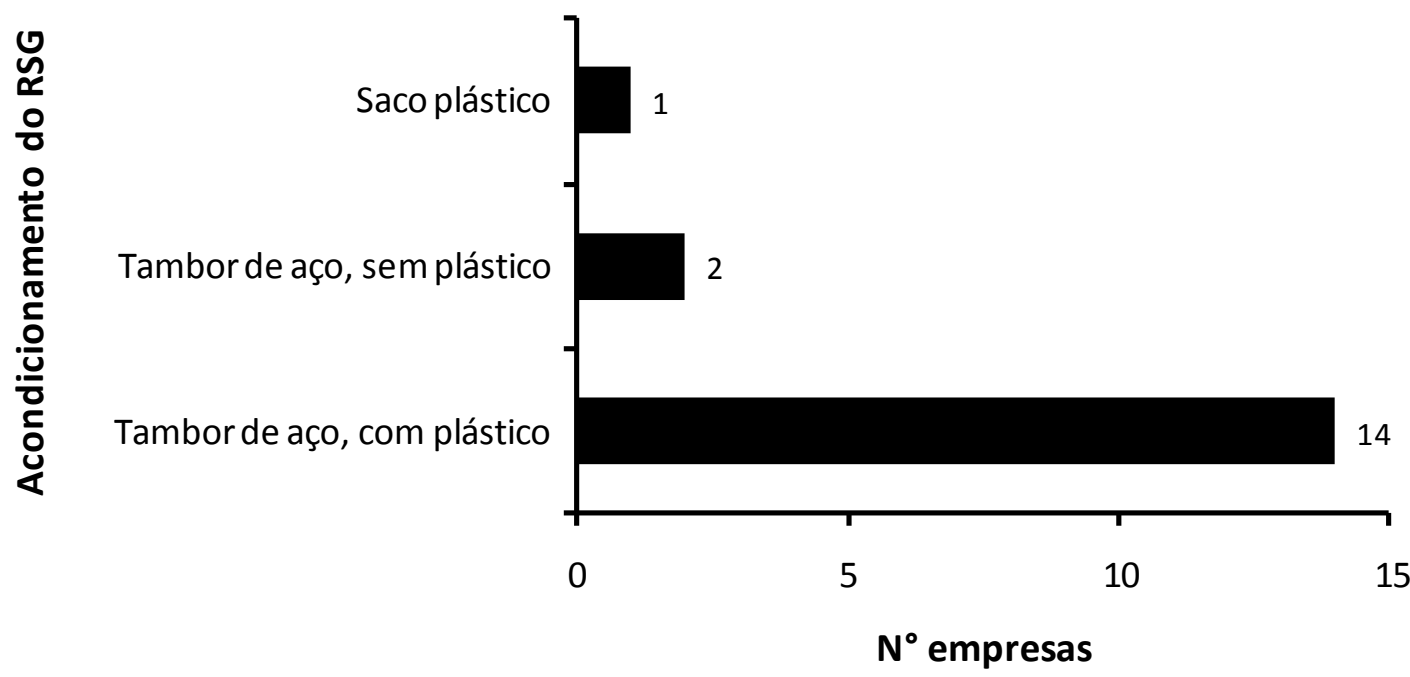

FIGURA 22 - Distribuição do número de empresas de acordo com o acondicionamento do RSG

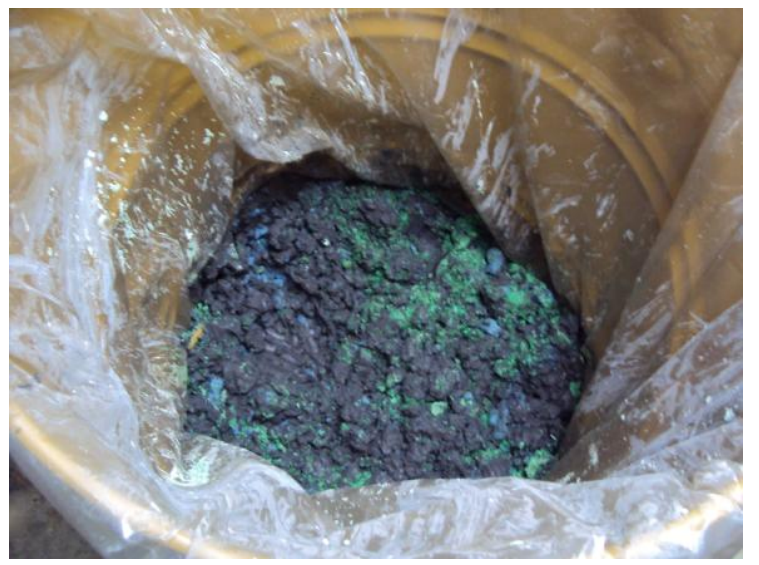

FIGURA 21 - Acondicionamento de lodo em tambor, com saco plástico, porém, sem rotulagem nas paredes externas (não visível)

Após o tratamento de efluentes, os lodos geralmente apresentam cerca de $60 \%$ a $75 \%$ de água inicialmente ${ }^{77}$. Na FIG. 20, é possível perceber a presença de umidade. Com o passar do tempo, este teor diminui, pois há evaporação. Na FIG. 18, pode ser notado um resíduo com menor teor de umidade. A secagem do lodo é um fator importante, pois, como as empresas pagam por tonelada para realizar a destinação, a presença de umidade em excesso faz com que o preço pago seja maior. Por isto, as empresas realizam as etapas de secagem. A distribuição do número de empresas de acordo com o tipo de secagem adotado está apresentada na FIG. 23.

A maioria das empresas consultadas utiliza leitos de secagem para diminuir a umidade do lodo. Todos os leitos de secagem ficavam em áreas cobertas, onde não havia contato com a chuva. Os leitos de secagem geralmente 
têm forma retangular ou quadrada e são projetados para promover a drenagem e evaporação da água, pois utilizam mantas, filtros e agentes secantes em sua parte inferior. Na FIG. 24, é mostrado o leito de secagem de uma das empresas visitadas.

O filtro-prensa é tão utilizado quanto o leito de secagem. O filtro-prensa é projetado literalmente para prensar o lodo, de forma a extrair parte da umidade por compressão. É constituído de placas de ferro entre as quais se prendem os panos filtrantes. Na FIG. 25, é mostrado o filtro-prensa de uma das empresas visitadas.

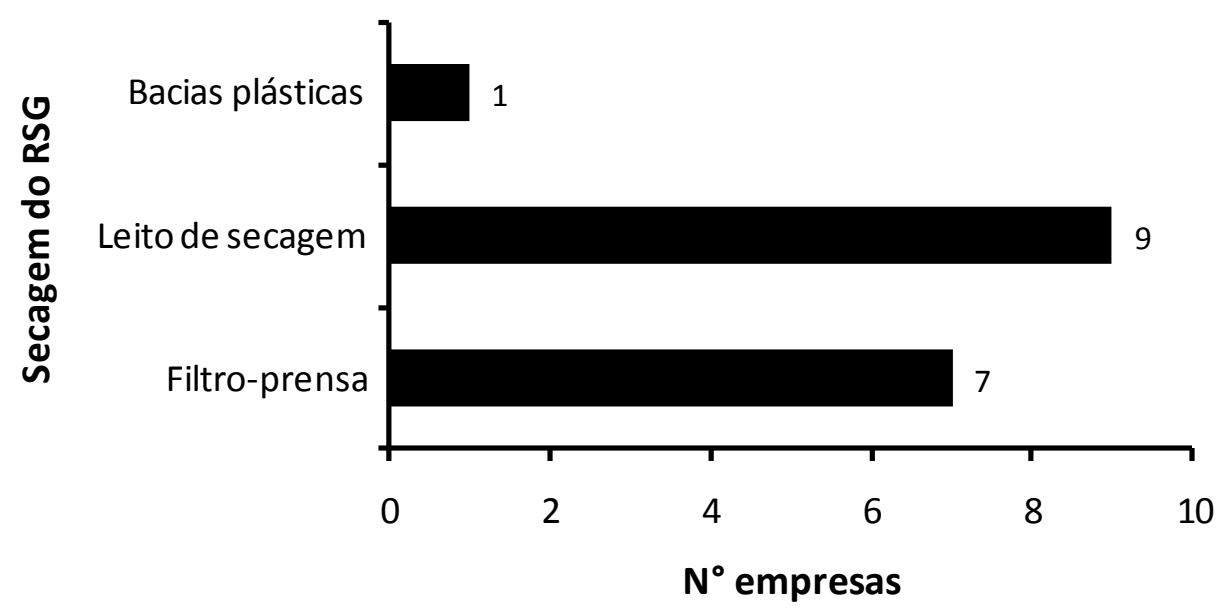

FIGURA 23 - Distribuição do número de empresas de acordo com o tipo de secagem do RSG

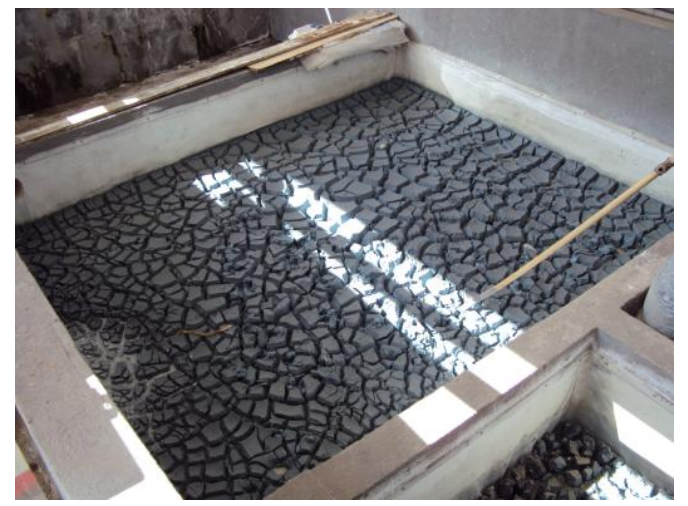

FIGURA 24 - Exemplo de leito de secagem

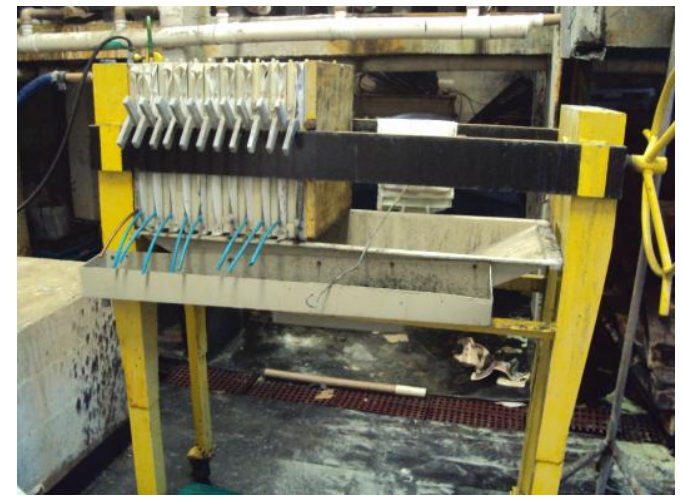

FIGURA 25 - Exemplo de filtro-prensa

Como conclusão das principais respostas obtidas nos questionários, é possível observar a falta de uma real preocupação com as questões ambientais. Ao perguntar aos empresários qual a destinação mais adequada para os resíduos sólidos, visando o setor de cromação como o maior interessado, todos informaram que não sabiam, sendo que alguns deram uma segunda resposta, mencionando sobre o reaproveitamento dos metais no próprio processo produtivo. 
O reaproveitamento dos metais no processo produtivo seria vantajoso, desde que o custo fosse reduzido e a pureza fosse a mesma encontrada nos reagentes comercializados, no entanto, na prática, isto não ocorre. Algumas empresas promovem a reciclagem dos metais, transformando-os em sais ou óxidos ricos em um determinado metal, mas com a presença de outros. No processo de galvanoplastia, são exigidos sais de alta pureza para o funcionamento dos banhos. A presença de outros metais é entendida como contaminação para o processo. Desta forma, atualmente estes sais e óxidos não retornam à linha produtiva e são encaminhados às fundições, cerâmicas e outras indústrias da área da química.

É importante mencionar que, ainda que seja pela pressão dos órgãos fiscalizadores, nos últimos anos o cenário ambiental melhorou nestas empresas, pois a maioria já contrata empresas especializadas para a destinação de seus resíduos sólidos, porém, mesmo destinando, as galvanoplastias acabam os mantendo estocados por alguns meses ou até anos, até atingir uma determinada quantidade, conservando um preocupante "passivo ambiental". Além disto, a maioria das empresas informou que manter o resíduo sólido armazenado ocupa um espaço que poderia ser aproveitado como área produtiva e há gastos com mão de obra e materiais para mantê-los estocados, correndo-se o risco de afetar a saúde dos funcionários, a população ao redor e o meio ambiente.

\subsubsection{Aspectos econômicos das destinações dos resíduos sólidos galvânicos}

Diversas são as possibilidades de destinação dos RSGs atualmente. Porém, os custos se alteram de acordo com a finalidade. O estudo realizado por meio da aplicação do questionário mostrou que os valores pagos pelas empresas de galvanoplastia da zona leste da cidade de São Paulo para destinar os resíduos sólidos é, em sua maioria, da ordem de $R \$ 300,00$ a $R \$ 500,00$ por tonelada. No entanto, o estudo indica que boa parte das empresas não destina seus resíduos sólidos, conforme FIG. 26. Este cenário vem se alterando ao longo dos anos para uma situação melhor, uma vez que há cerca de 5 a 10 anos quase nenhuma empresa destinava seus resíduos sólidos, porém, ainda é crítico, por se tratar da criação de um crescente e preocupante passivo ambiental, em uma região extremamente povoada. 


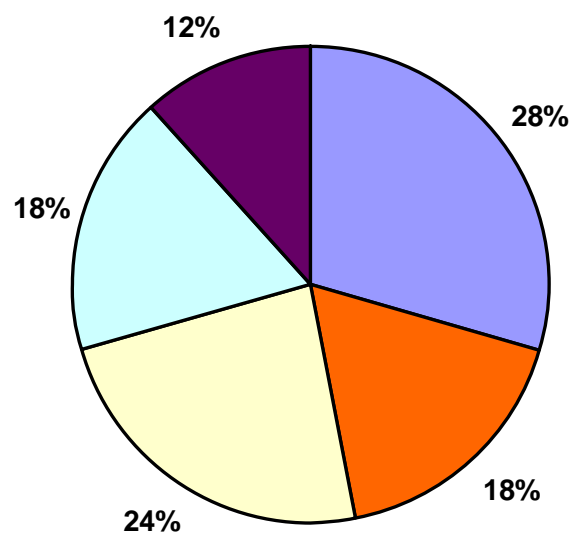

口Não destina o RSG

口Não sabe o custo

aR $\$ 300,00$ a $R \$ 500,00 / t$ de $R S G$

口R $\$ 501,00$ a $R \$ 750,00 /$ t de RSG

a $\$ 751,00$ a $R \$ 1.000,00 / \mathrm{t}$ de $R S G$

FIGURA 26 - Distribuição da porcentagem de empresas de acordo com o custo pago para a destinação do lodo

$\mathrm{Na}$ TAB. 13, estão apresentados os custos de cada destinação, fornecidos pelas empresas que prestam tais serviços. Os custos são adotados atualmente e podem variar, pois, em alguns casos, mais de uma empresa executa o mesmo serviço. As empresas consultadas autorizaram a menção de seus nomes neste trabalho.

TABELA 13 - Destinações possíveis para os RSGs e seus custos

\begin{tabular}{|c|c|c|}
\hline Destinação & $\begin{array}{l}\text { Custo por tonelada } \\
\text { de resíduo }(R \$)\end{array}$ & Fonte \\
\hline “Estocagem" & 300,00 & $\begin{array}{l}\text { Preço aproximado de } 5 \text { tambores de } \\
250 \mathrm{~L}+\text { porcentagem de parcela de IPTU } \\
\text { de área ocupada sem utilização produtiva }\end{array}$ \\
\hline Aterro Classe I & 270,00 & Essencis Soluções Ambientais S.A. \\
\hline $\begin{array}{c}\text { Incineração (destruição } \\
\text { térmica, transformando em } \\
\text { cinzas tóxicas) }\end{array}$ & $\begin{array}{l}3.500,00 \mathrm{a} \\
10.000,00\end{array}$ & Essencis Soluções Ambientais S.A. \\
\hline $\begin{array}{l}\text { Coprocessamento (destruição } \\
\text { térmica em fornos de cimento) }\end{array}$ & 420,00 & Essencis Soluções Ambientais S.A. \\
\hline \multirow{2}{*}{$\begin{array}{l}\text { Plasma térmico (destruição } \\
\text { térmica, transformando em } \\
\text { matriz vítrea) }\end{array}$} & $1.800,00$ & $\begin{array}{l}\text { Centralsuper Com. de Produtos Químicos } \\
\text { Ltda }\end{array}$ \\
\hline & $2.000,00$ & $\begin{array}{l}\text { Ecochamas Tratamento de Resíduos } \\
\text { Industrais Ltda }\end{array}$ \\
\hline $\begin{array}{l}\text { Transformação em lingotes } \\
\text { metálicos }\end{array}$ & 550,00 & Ecológica Nora Era Ind. e Com. Ltda \\
\hline \multirow{2}{*}{$\begin{array}{l}\text { Transformação em sais e } \\
\text { óxidos metálicos }\end{array}$} & 440,00 & Suzaquim Ind. Química Ltda \\
\hline & 0,00 a $600,00^{*}$ & WRC do Brasil Ltda* \\
\hline $\begin{array}{l}\text { Transformação em } \\
\text { micronutrientes para a } \\
\text { agricultura (solos) }\end{array}$ & $\begin{array}{l}\text { 350,00 (associados) } \\
570,00 \text { (não- } \\
\text { associados) }\end{array}$ & $\begin{array}{c}\text { Centralsuper Com. de Produtos Químicos } \\
\text { Ltda (envia para a empresa Hebert \& } \\
\text { Hegert Johanssen Recuperados de } \\
\text { Resíduos Ltda) }\end{array}$ \\
\hline
\end{tabular}

*A WRC, em alguns casos, compra o resíduo sólido, se for rico em cobre, níquel, estanho, ouro ou prata. 
De acordo com os custos aproximados das destinações atualmente realizadas, nota-se que a estocagem realmente não é indicada, pois além de criar um passivo ambiental e tomar um espaço que poderia ser aproveitado para o processo produtivo, ainda não é gratuito, uma vez que é necessário adquirir tambores para o armazenamento, além de ser preciso identificar o resíduo e manuseá-lo com cuidados especiais. A disposição em aterro classe I parece ser a destinação mais econômica, mas, conforme já tratado, não é ideal para o ambiente. Existem opções interessantes que transformam o resíduo em outro material para voltar à cadeia produtiva e os custos não são muito mais elevados em comparação com o aterramento, porém, com a ressalva de que não são ideais para retornar à galvanoplastia, devido à pureza dos sais ou lingotes. Os maiores custos de destinação são a incineração e o plasma térmico, que envolvem alto consumo de energia, além da tecnologia avançada, no caso da inertização por plasma.

Independentemente da destinação, chega-se à conclusão que deveriam existir ações em âmbito governamental para a retirada dos resíduos sólidos das empresas de galvanoplastia, a fim de eliminar o enorme e crescente passivo ambiental, que apresenta risco de ser liberado para o ambiente de forma quimicamente ativa, causando danos irreparáveis ao meio ambiente e à saúde humana, principalmente, nas regiões densamente povoadas onde se encontram.

\subsection{Parte B - Resultados experimentais visando uma aplicação tecnológica para os resíduos sólidos galvânicos}

Com o objetivo de oferecer uma aplicação tecnológica para os RSGs, as amostras selecionadas foram caracterizadas para avaliar seus aspectos químicos e físicos e, posteriormente, após uma nova seleção, amostras foram incorporadas a uma composição vítrea, para promover a mitigação dos elementos considerados perigosos para o meio ambiente e para o ser humano.

\subsubsection{Caracterização química e físico-química dos resíduos sólidos galvânicos}

Os ensaios para caracterização química e físico-química dos RSGs foram realizados por diversas técnicas e os resultados obtidos estão apresentados a seguir. 
Primeiramente, as análises qualitativas por FRX e EDS foram utilizadas para detectar os elementos presentes nos RSGs analisados. Na TAB. 14, os resultados estão apresentados por ordem de preponderância. São considerados "preponderantes" os elementos com teores semiquantitativos entre $10 \%$ e $50 \%$ em massa. São considerados como de "pequenas proporções", os elementos com teores semiquantitativos entre $1 \%$ e $10 \%$ em massa e são considerados como "traços" os elementos com teores semiquantitativos entre $0 \%$ e $1 \%$ em massa.

Observa-se que os elementos cobre, níquel, cromo e oxigênio, destacados em negrito, são preponderantes na maioria dos RSGs analisados, pelo fato de serem utilizados em banhos de cobre, níquel e cromo nos processos produtivos, onde os arrastes e águas de lavagens são direcionados para a ETE, formando óxidos, hidróxidos, carbonatos e sulfatos no lodo. A empresa $n^{\circ} 5$ não possui banho de cromo e, por isto, este elemento foi detectado na forma de traço no RSG 5.

TABELA 14 - Resultado dos elementos detectados nos RSGs, por FRX e EDS

\begin{tabular}{|c|c|c|c|c|c|}
\hline \multirow{2}{*}{$\begin{array}{c}\text { Ordem de } \\
\text { preponderância }\end{array}$} & \multicolumn{5}{|c|}{ Proporção dos elementos } \\
\hline & RSG 1 & RSG 2 & RSG 3 & RSG 4 & RSG 5 \\
\hline Preponderantes & $\begin{array}{c}\mathrm{Ni}, \mathrm{O}, \mathrm{Cr} \mathrm{e} \\
\mathrm{Cu}\end{array}$ & O, Ni e Cr & $\underset{\mathrm{Ni}}{\mathrm{O}, \mathrm{Cr}, \mathrm{Cu} \text { e }}$ & $\underset{\mathrm{Cr}}{\mathrm{O}, \mathrm{Ca}, \mathrm{Ni} \mathrm{e}}$ & $\mathrm{Cu}, \mathrm{O}$ e $\mathrm{Ni}$ \\
\hline $\begin{array}{l}\text { Pequenas } \\
\text { proporções }\end{array}$ & C, S, Na e Ca & $\begin{array}{l}\mathrm{Ca}, \mathrm{C}, \mathrm{Cu} \\
\mathrm{Fe}, \mathrm{S}, \mathrm{Na} \text { e } \\
\mathrm{Zn}\end{array}$ & $\mathrm{S}, \mathrm{C}, \mathrm{Na}$ e $\mathrm{Ca}$ & $\begin{array}{c}\mathrm{S}, \mathrm{C}, \mathrm{Cu}, \mathrm{Fe} \\
\mathrm{e} \mathrm{Si}\end{array}$ & $\mathrm{CeK}$ \\
\hline Traços & $\begin{array}{c}\mathrm{Zn}, \mathrm{Fe}, \mathrm{Si}, \mathrm{P}, \\
\mathrm{Mg}, \mathrm{Cl}, \mathrm{Al}, \\
\mathrm{Mn}, \mathrm{Sn}, \mathrm{Pb} \\
\mathrm{Ba} \text { e K }\end{array}$ & $\begin{array}{c}\text { Cl, Si, Mg, } \\
\text { Mn, Al, Ba, } \\
\text { Sn, P, K, Sr e } \\
\text { Y }\end{array}$ & $\begin{array}{c}\mathrm{Cl}, \mathrm{Si}, \mathrm{Zn}, \mathrm{P}, \\
\mathrm{Ba}, \mathrm{Fe}, \mathrm{Al}, \\
\mathrm{Pb}, \mathrm{Mg}, \mathrm{Sn}, \\
\mathrm{K}, \mathrm{Sr} \text { e } \mathrm{Mn}\end{array}$ & $\begin{array}{c}\mathrm{Cl}, \mathrm{Na}, \mathrm{Mg}, \\
\mathrm{Ba}, \mathrm{Al}, \mathrm{Pb}, \mathrm{P}, \\
\mathrm{Sr}, \mathrm{Zn} \text { e Sn }\end{array}$ & $\begin{array}{c}\mathrm{Zn}, \mathrm{Fe}, \mathrm{Na}, \mathrm{S}, \\
\mathrm{Mg}, \mathrm{Br}, \mathrm{Al}, \\
\mathrm{Ca}, \mathrm{P}, \mathrm{Si}, \mathrm{Cr}, \\
\mathrm{Cl} \text { e Co }\end{array}$ \\
\hline
\end{tabular}

Com base nas análises qualitativas, foram realizadas as análises quantitativas para detectar os teores exatos dos elementos presentes nos RSGs. $\mathrm{Na}$ TAB. 15, estão apresentados os resultados obtidos por ICP-AES, FAAS, gravimetria e titulação potenciométrica. Os elementos destacados em negrito representam os maiores teores detectados (entre $10 \%$ e $50 \%$ em massa) e os resultados destacados em itálico representam os teores em pequenas proporções (entre $1 \%$ e $10 \%$ em massa). Os resultados não destacados representam os teores na forma de traço e não detectados. 
Observa-se que os RSGs são constituídos, em sua maior parte, por metais pesados considerados perigosos para o meio ambiente e para a saúde humana. No RSG 1, tais elementos somam aproximadamente $67 \%$ da massa total; no RSG 2, somam 59\%; no RSG 3, somam 50\%; no RSG 4, somam 32\% e no RSG 5, somam 56\%. Estes elementos podem ser utilizados para se obter materiais vítreos, pois podem fazer parte da estrutura como modificadores. Além dos metais pesados, os RSGs ainda possuem outros elementos utilizados para se obter vidros, como silício, boro, cálcio, sódio, potássio, magnésio e outros.

Nos resíduos sólidos das empresas 1, 2, 3 e 4 (RSG 1, RSG 2, RSG 3 e RSG 4), que têm similaridades em seus processos produtivos, os elementos predominantes foram o $\mathrm{Ni}$ e o $\mathrm{Cr}$. O Cu também é encontrado em porcentagens elevadas nos RSGs de empresas de cromação, porém, nos RSGs das empresas 2 e 4, estava presente em pequena quantidade $(1,99 \%$ e 0,65\%, respectivamente). Durante as visitas às empresas, observou-se que nestes dois processos, os banhos de cobre eram menos utilizados, provocando a menor quantidade de $\mathrm{Cu}$ nos respectivos RSGs. Como demais elementos em proporções significativas, foi detectado o B nos RSGs das empresas de 1 a 3 (entre 12\% e 16\%) e o Ca nos RSGs das empresas 2 e 4 (8,14\% e 18,03\%, respectivamente), devido à semelhança dos reagentes utilizados.

Já nos resíduos sólidos da empresa 5 (RSG 5), por se tratar de processo de douração, o $\mathrm{Cu}$ e o Ni foram os principais constituintes encontrados, uma vez que, conforme anteriormente mencionado, os banhos utilizados neste processo são de cobre, níquel e ouro. O ouro presente nas águas de lavagem das peças é totalmente recuperado por processos químicos e, portanto, não foi encontrado. Por outro lado, o teor de cromo é encontrado na forma de traço $(0,38 \%)$, justamente pelo fato de não se utilizar banho de cromo neste processo.

TABELA 15 - Resultado dos teores dos elementos nos RSGs, por ICP-AES, FAAS, gravimetria e titulação potenciométrica

\begin{tabular}{c|c|c|c|c|c}
\hline \multirow{2}{*}{ Elem. } & \multicolumn{5}{|c}{ Teores dos elementos (\% em massa) } \\
\cline { 2 - 6 } & RSG 1 & RSG 2 & RSG 3 & RSG 4 & RSG 5 \\
\hline $\mathrm{Ag}$ & $0,0010 \pm 0,0004$ & $0,0001 \pm 0,0001$ & $0,0005 \pm 0,0002$ & - & - \\
\hline $\mathrm{Al}$ & $0,1499 \pm 0,0082$ & $0,2247 \pm 0,0112$ & $0,3809 \pm 0,0325$ & $0,141 \pm 0,004$ & $0,003 \pm 0,002$ \\
\hline $\mathrm{Au}$ & $0,0076 \pm 0,0022$ & - & $0,0051 \pm 0,0010$ & - & -
\end{tabular}




\begin{tabular}{|c|c|c|c|c|c|}
\hline \multirow{2}{*}{ Iem. } & \multicolumn{5}{|c|}{ Teores dos elementos (\% em massa) } \\
\hline & RSG 1 & RSG 2 & RSG 3 & RSG 4 & RSG 5 \\
\hline B & $16,1042 \pm 1,3424$ & $12,5386 \pm 2,6083$ & $13,4104 \pm 0,3069$ & $0,356 \pm 0,030$ & $0,036 \pm 0,005$ \\
\hline $\mathrm{Ba}$ & $0,0014 \pm 0,0012$ & $0,0713 \pm 0,0037$ & $0,4251 \pm 0,0249$ & $0,151 \pm 0,006$ & - \\
\hline $\mathrm{Ca}$ & $1,2801 \pm 0,0922$ & $8,1440 \pm 0,2394$ & $4,1362 \pm 0,6010$ & $18,027 \pm 0,351$ & $0,920 \pm 0,431$ \\
\hline $\mathrm{Cd}$ & $0,0003 \pm 0,0001$ & $0,0002 \pm 0,0001$ & $0,0002 \pm 0,0002$ & - & $0,0020 \pm 0,0001$ \\
\hline $\mathrm{Cl}^{-}$ & $0,3208 \pm 0,0900$ & $0,7404 \pm 0,0300$ & $0,7759 \pm 0,1000$ & $0,4732 \pm 0,0800$ & $2,6093 \pm 0,4000$ \\
\hline Co & $0,0016 \pm 0,0002$ & $0,0014 \pm 0,0009$ & - & - & - \\
\hline $\mathrm{Cr}$ & $15,8935 \pm 0,8442$ & $21,2579 \pm 0,4089$ & $33,7337 \pm 1,4138$ & $9,382 \pm 0,082$ & $0,384 \pm 0,272$ \\
\hline $\mathrm{Cu}$ & $6,8637 \pm 0,1851$ & $1,9924 \pm 0,0488$ & $6,0372 \pm 0,5443$ & $0,649 \pm 0,011$ & $36,922 \pm 2,519$ \\
\hline $\mathrm{Fe}$ & $0,7561 \pm 0,0616$ & $4,1295 \pm 0,0661$ & $0,6196 \pm$ & $1,725 \pm 0,012$ & 0,429 \\
\hline $\mathrm{K}$ & $0,0357 \pm 0,0085$ & $0,0<00 \perp 0,0$ & $0,0740 \pm 0,0186$ & $0,0040 \pm 0,0001$ & $0,881 \pm 0,057$ \\
\hline $\mathrm{Mg}$ & $0,4332 \pm 0,0231$ & $1,2602 \pm 0,0231$ & $0,2172 \pm 0,0182$ & $0,263 \pm 0,026$ & $0,090 \pm 0,010$ \\
\hline $\mathrm{Mn}$ & $0,1014 \pm 0,0072$ & $0,0702 \pm 0,0016$ & $0,0054 \pm 0,0003$ & $0,008 \pm 0,001$ & $0,018 \pm 0,005$ \\
\hline $\mathrm{Na}$ & $1,9164 \pm 0,3383$ & $2,8252 \pm 0,0862$ & $3,9756 \pm 0,6051$ & $0,540 \pm 0,015$ & $0,492 \pm 0,014$ \\
\hline $\mathrm{Ni}$ & $41,5272 \pm 0,7930$ & $28,5832 \pm 0,5340$ & $7,7664 \pm 0,3028$ & $19,700 \pm 0,064$ & $17,315 \pm 4,028$ \\
\hline$P$ & $0,5064 \pm 0,0197$ & $0,0424 \pm 0,0397$ & $0,5991 \pm 0,0488$ & $0,043 \pm 0,003$ & $0,393 \pm 0,005$ \\
\hline $\mathrm{Pb}$ & $0,0824 \pm 0,0013$ & $0,0601 \pm 0,0024$ & $0,3546 \pm 0,0025$ & $0,119 \pm 0,009$ & $0,0030 \pm 0,0001$ \\
\hline $\mathrm{Pd}$ & $0,0004 \pm 0,0003$ & - & $0,0008 \pm 0,0001$ & - & $0,0020 \pm 0,0001$ \\
\hline $\mathrm{Pt}$ & $0,1140 \pm 0,0530$ & $0,0006 \pm 0,0024$ & $0,1113 \pm 0,0382$ & $0,068 \pm 0,016$ & $0,082 \pm 0,025$ \\
\hline$S$ & $4,67 \pm 0,42$ & $3,28 \pm 0,40$ & $5,92 \pm 0,55$ & $5,59 \pm 0,62$ & $0,37 \pm 0,10$ \\
\hline $\mathrm{Si}$ & $0,2993 \pm 0,0580$ & $0,2119 \pm 0,0104$ & $0,1269 \pm 0,0523$ & $1,053 \pm 0,060$ & $0,024 \pm 0,001$ \\
\hline Sn & $0,0411 \pm 0,0013$ & $0,0070 \pm 0,0053$ & $0,0521 \pm 0,0012$ & $0,012 \pm 0,005$ & - \\
\hline $\mathrm{Sr}$ & $0,0055 \pm 0,0009$ & $0,0068 \pm 0,0012$ & $0,0099 \pm 0,0003$ & $0,017 \pm 0,003$ & - \\
\hline $\mathrm{Y}$ & $0,0005 \pm 0,0001$ & $0,0049 \pm 0,0010$ & $0,0003 \pm 0,0001$ & 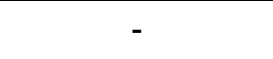 & 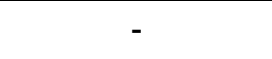 \\
\hline $\mathrm{Zn}$ & $1,2051 \pm 0,0343$ & $2,6935 \pm 0,0329$ & $1,0028 \pm 0,0322$ & $0,078 \pm 0,009$ & $0,503 \pm 0,041$ \\
\hline
\end{tabular}

Nota 1: Valores com intervalo de $95 \%$ de confiança

Nota 2: Valores não normalizados

Em relação às origens dos metais nos RSGs, observou-se que são provenientes das águas de lavagem direcionadas à ETE e dos produtos utilizados para realizar o tratamento dos efluentes, tais quais os mencionados na pergunta $\mathrm{n}^{\circ} 5$ do questionário aplicado às empresas, apresentado no APÊNDICE.

Após as análises químicas, foram realizadas análises para estudar as características físico-químicas dos RSGs. As análises por ATD/ATG foram conduzidas para avaliar o comportamento dos materiais com o aumento da temperatura, visando uma aplicação tecnológica a altas temperaturas. Baseandose nos resultados obtidos por esta técnica, as amostras foram analisadas por 
DRX para detectar os compostos formados e por MEV-FEG para estudar suas microestruturas e confirmar a presença dos compostos formados, com auxílio do EDS. Para isto as amostras foram tratadas previamente em temperaturas que pudessem ser relevantes para todos os ATDs/ATGs. As temperaturas definidas foram: ambiente (T amb.), $110^{\circ} \mathrm{C}, 600^{\circ} \mathrm{C}, 900^{\circ} \mathrm{C}$ e $1400^{\circ} \mathrm{C}$.

Os resultados apresentados a seguir estão agrupados de acordo com cada amostra de RSG analisada, correlacionando os resultados obtidos por todas as técnicas, para a melhor interpretação dos dados. Antes das análises, todas as amostras tiveram os mesmos tratamentos iniciais, para fins comparativos.

O comportamento da amostra de RSG 1 com o aumento da temperatura, por meio das análises de ATD e ATG, está apresentado na FIG. 27. Observa-se que até a temperatura de aproximadamente $450^{\circ} \mathrm{C}$ ocorre uma perda acentuada de massa (28\%), principalmente, pela eliminação de água livre e combinada. $\mathrm{O}$ pico endotérmico em $97^{\circ} \mathrm{C}$ indica evaporação de água e os picos endotérmicos em $172^{\circ} \mathrm{C}$ e $374^{\circ} \mathrm{C}$ indicam, provavelmente, desidratação do sulfato de cálcio, conforme os resultados obtidos por DRX, apresentados na FIG. 28, onde na amostra tratada a $600^{\circ} \mathrm{C}$, é observada somente a presença de sulfato de cálcio anidro. Pela literatura ${ }^{79}$, o sulfato de cálcio di-hidratado libera água de cristalização a $128^{\circ} \mathrm{C}$ e o mesmo ocorre a $163^{\circ} \mathrm{C}$ para o sulfato de cálcio meio hidratado.

Ainda na FIG. 27, a curva de perda de massa continua decrescendo até a temperatura máxima utilizada no ensaio $\left(1400^{\circ} \mathrm{C}\right)$. A perda de massa total foi de $41 \%$ em relação à massa inicial. Alguns pontos de mudança de comportamento na perda de massa são observados, conforme mostra a curva da derivada da massa, que indica a velocidade de perda de massa. Similarmente, nos mesmos pontos, a curva de ATD apresenta picos endotérmicos discretos a $521^{\circ} \mathrm{C}, 783^{\circ} \mathrm{C}$ e $1147^{\circ} \mathrm{C}$. O pico a $521^{\circ} \mathrm{C}$ é relacionado à decomposição de $\mathrm{CaCO}_{3}$ e este fenômeno pôde ser comprovado nas análises por DRX, para a amostra de RSG 1 tratada termicamente a $600^{\circ} \mathrm{C}$, onde, nesta temperatura, não se observa mais os picos deste composto (FIG. 28). Segundo a literatura ${ }^{79}, \mathrm{O}_{\mathrm{CaCO}_{3}}$ na forma de aragonita apresenta ponto de fusão e transição para calcita a $520^{\circ} \mathrm{C}$. $\mathrm{O}$ pico registrado a $783^{\circ} \mathrm{C}$ pode corresponder a uma decomposição envolvendo níquel ou cromo, devido aos seus elevados teores na amostra, ou ao final da decomposição do $\mathrm{CaCO}_{3}$. Nas análises por $\mathrm{DRX}$, não se observou nenhuma 
alteração nas amostras tratadas termicamente a $600^{\circ} \mathrm{C}$ e $900^{\circ} \mathrm{C}$, que pudesse justificar o aparecimento deste pico (FIG. 28). O pico a $1147^{\circ} \mathrm{C}$ é relacionado, provavelmente, à decomposição de sulfato de cálcio. Nas análises por DRX, os picos relativos a este composto não foram mais observados na amostra tratada a $1400^{\circ} \mathrm{C}$. Pela literatura ${ }^{79}$, o sulfato de cálcio anidro apresenta ponto de vaporização e transição cristalográfica de ortorômbica para monoclínica a $1193^{\circ} \mathrm{C}$.

Nos difratogramas obtidos a partir da amostra de RSG 1 (FIG. 28), observa-se a formação de compostos com o aumento da temperatura, de acordo com os detalhes apresentados na TAB. 16. Alguns destes compostos, como os cromatos de níquel e de cálcio, são difíceis de serem obtidos e são interessantes para o setor cerâmico e para a área de materiais como um todo, demonstrando que o próprio tratamento térmico da amostra já proporciona resultados importantes. O mesmo pode ser observado para os RSGs das outras amostras.

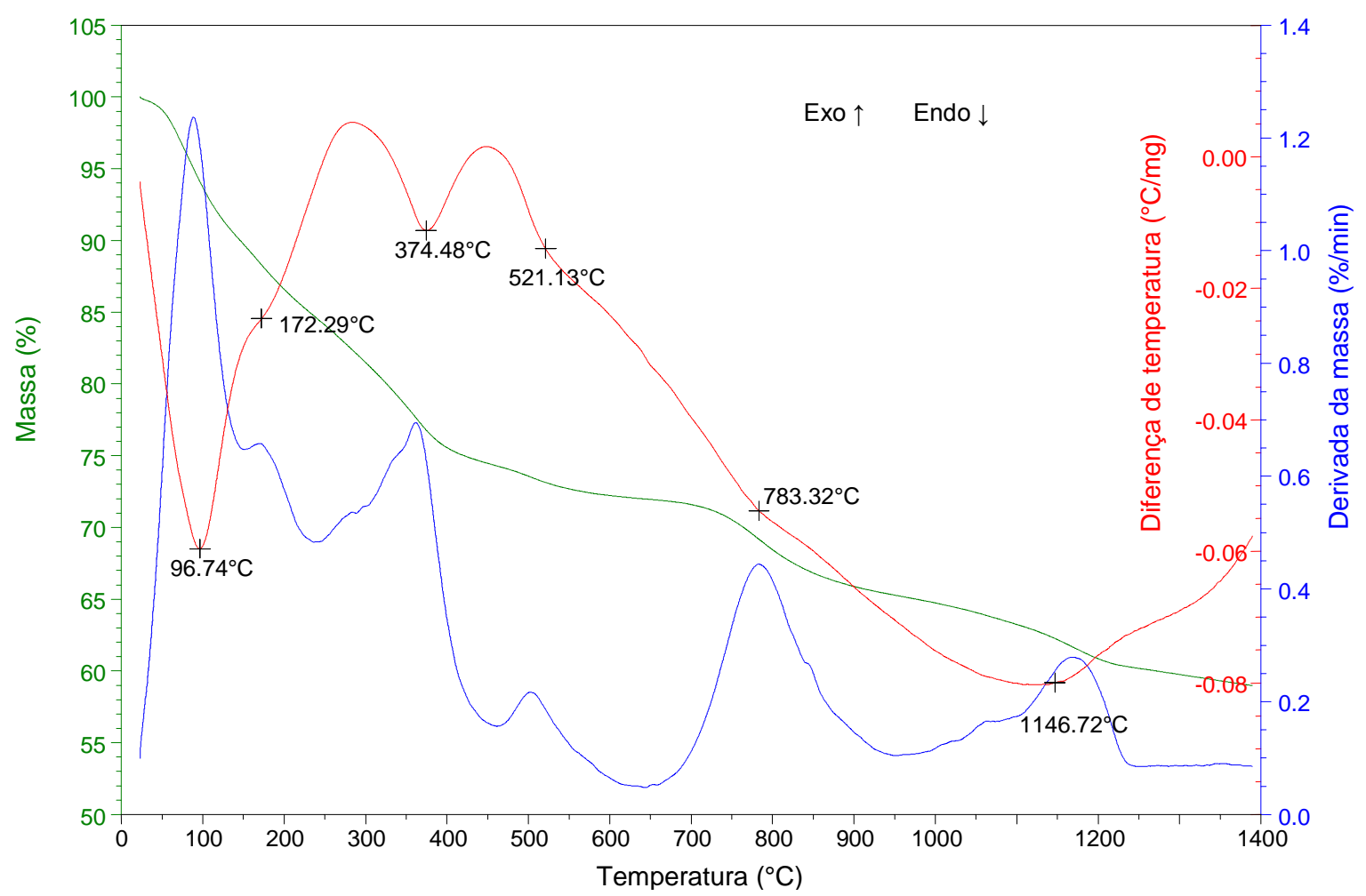

FIGURA 27 - Resultado de ATD/ATG obtido para a amostra RSG 1 (temperatura até $1400^{\circ} \mathrm{C}$, taxa de aquecimento de $10^{\circ} \mathrm{C} / \mathrm{min}$ e atmosfera de ar sintético) 


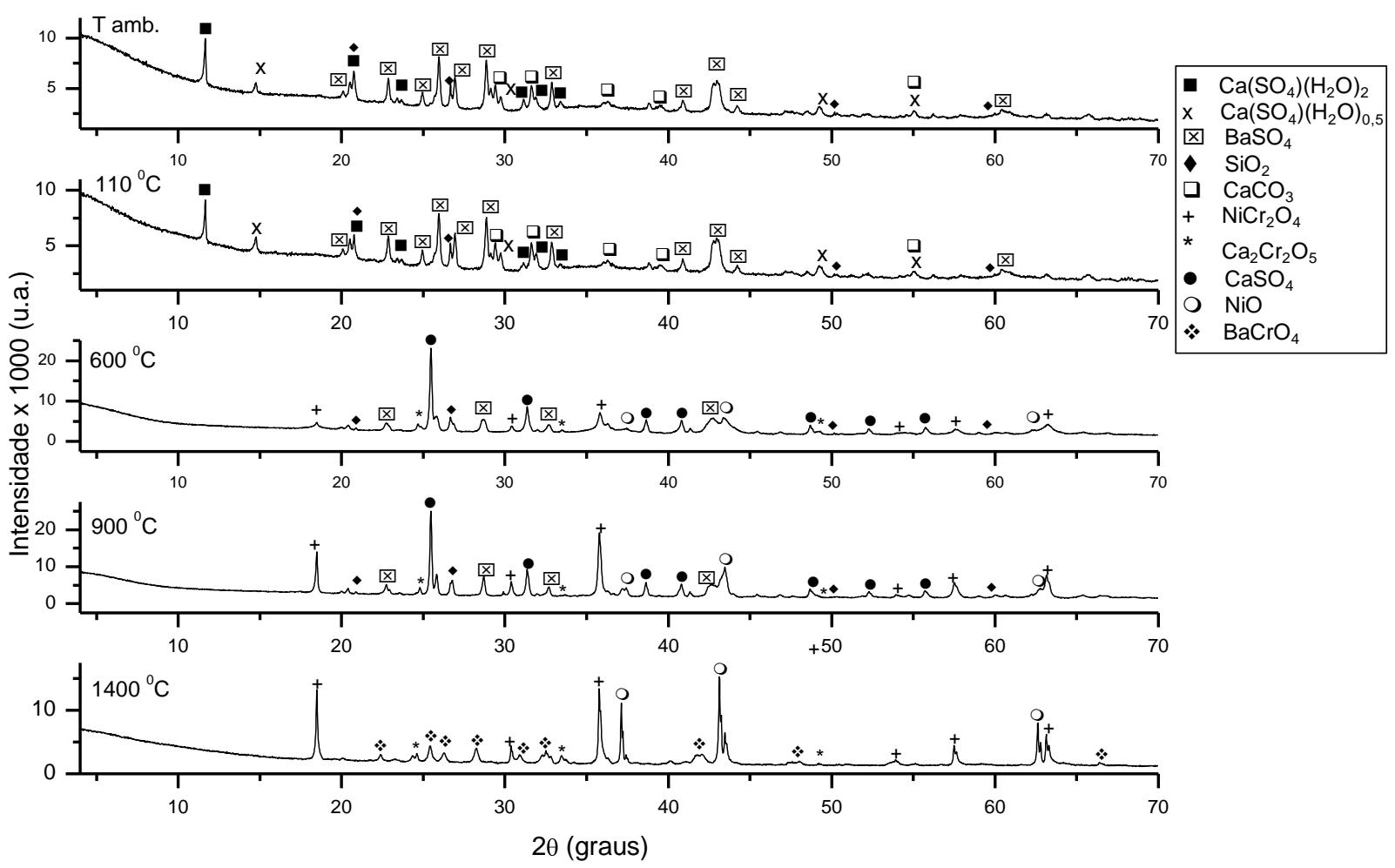

FIGURA 28 - Difratogramas obtidos para a amostra RSG 1, após tratamento em diferentes temperaturas (tubo de cobre)

TABELA 16 - Resultado dos compostos identificados por DRX na amostra RSG 1, após tratamentos térmicos

\begin{tabular}{|c|c|c|c|c|c|}
\hline \multirow{3}{*}{ Amostra } & \multirow{3}{*}{$\begin{array}{c}\text { Tratamento } \\
\text { térmico } \\
\text { (3 h / ar) }\end{array}$} & \multicolumn{4}{|c|}{ Compostos } \\
\hline & & \multirow{2}{*}{ Nome } & \multirow{2}{*}{$\begin{array}{l}\text { Fórmula } \\
\text { química }\end{array}$} & \multicolumn{2}{|c|}{ Ficha de padrão de difração* } \\
\hline & & & & PDF 2* & Nome $^{*}$ \\
\hline \multirow{10}{*}{ RSG 1} & \multirow{5}{*}{ T amb. } & \multirow{2}{*}{$\begin{array}{l}\text { Sulfato de cálcio } \\
\text { hidratado }\end{array}$} & $\mathrm{Ca}\left(\mathrm{SO}_{4}\right)\left(\mathrm{H}_{2} \mathrm{O}\right)_{2}$ & 01-070-0982 & Gesso \\
\hline & & & $\mathrm{Ca}\left(\mathrm{SO}_{4}\right)\left(\mathrm{H}_{2} \mathrm{O}\right)_{0,5}$ & 01-081-1848 & $\begin{array}{c}\text { Sulfato de cálcio } \\
\text { hidratado }\end{array}$ \\
\hline & & Sulfato de bário & $\mathrm{BaSO}_{4}$ & 01-076-0213 & Barita \\
\hline & & Óxido de silício & $\mathrm{SiO}_{2}$ & 01-085-0796 & Quartzo \\
\hline & & $\begin{array}{l}\text { Carbonato de } \\
\text { cálcio }\end{array}$ & $\mathrm{CaCO}_{3}$ & $01-083-0578$ & Calcita \\
\hline & \multirow{5}{*}{$110^{\circ} \mathrm{C}$} & \multirow{2}{*}{$\begin{array}{l}\text { Sulfato de cálcio } \\
\text { hidratado }\end{array}$} & $\mathrm{Ca}\left(\mathrm{SO}_{4}\right)\left(\mathrm{H}_{2} \mathrm{O}\right)_{2}$ & 01-070-0982 & Gesso \\
\hline & & & $\mathrm{Ca}\left(\mathrm{SO}_{4}\right)\left(\mathrm{H}_{2} \mathrm{O}\right)_{0,5}$ & 01-081-1848 & $\begin{array}{c}\text { Sulfato de cálcio } \\
\text { hidratado }\end{array}$ \\
\hline & & Sulfato de bário & $\mathrm{BaSO}_{4}$ & 01-076-0213 & Barita \\
\hline & & Óxido de silício & $\mathrm{SiO}_{2}$ & 01-085-0796 & Quartzo \\
\hline & & $\begin{array}{l}\text { Carbonato de } \\
\text { cálcio }\end{array}$ & $\mathrm{CaCO}_{3}$ & $01-083-0578$ & Calcita \\
\hline
\end{tabular}




\begin{tabular}{|c|c|c|c|c|c|}
\hline \multirow{3}{*}{ Amostra } & \multirow{3}{*}{$\begin{array}{c}\text { Tratamento } \\
\text { térmico } \\
(3 \mathrm{~h} / \mathrm{ar})\end{array}$} & \multicolumn{4}{|c|}{ Compostos } \\
\hline & & \multirow{2}{*}{ Nome } & \multirow{2}{*}{$\begin{array}{l}\text { Fórmula } \\
\text { química }\end{array}$} & \multicolumn{2}{|c|}{ Ficha de padrão de difração* } \\
\hline & & & & PDF $2^{*}$ & Nome* \\
\hline \multirow{16}{*}{ RSG 1} & \multirow{6}{*}{$600^{\circ} \mathrm{C}$} & Sulfato de cálcio & $\mathrm{CaSO}_{4}$ & 01-070-0909 & Sulfato de cálcic \\
\hline & & Sulfato de bário & $\mathrm{BaSO}_{4}$ & 01-089-3749 & Barita \\
\hline & & Óxido de silício & $\mathrm{SiO}_{2}$ & 01-085-0796 & Quartzo \\
\hline & & $\begin{array}{c}\text { Óxido de cromo e } \\
\text { níquel }\end{array}$ & $\mathrm{NiCr}_{2} \mathrm{O}_{4}$ & 01-075-1728 & $\begin{array}{c}\text { Óxido de cromo } \\
\text { e níquel }\end{array}$ \\
\hline & & $\begin{array}{c}\text { Óxido de cromo e } \\
\text { cálcio }\end{array}$ & $\mathrm{Ca}_{2} \mathrm{Cr}_{2} \mathrm{O}_{5}$ & 00-048-0791 & $\begin{array}{l}\text { Óxido de cromo } \\
\text { e cálcio }\end{array}$ \\
\hline & & Óxido de níquel & $\mathrm{NiO}$ & $01-089-3080$ & Bunsenita, sin \\
\hline & \multirow{6}{*}{$900^{\circ} \mathrm{C}$} & Sulfato de cálcio & $\mathrm{CaSO}_{4}$ & 01-070-0909 & Sulfato de cálcic \\
\hline & & Sulfato de bário & $\mathrm{BaSO}_{4}$ & 01-089-3749 & Barita \\
\hline & & Óxido de silício & $\mathrm{SiO}_{2}$ & 01-085-0796 & Quartzo \\
\hline & & $\begin{array}{c}\text { Óxido de cromo e } \\
\text { níquel }\end{array}$ & $\mathrm{NiCr}_{2} \mathrm{O}_{4}$ & 01-075-1728 & $\begin{array}{c}\text { Óxido de cromo } \\
\text { e níquel }\end{array}$ \\
\hline & & $\begin{array}{l}\text { Óxido de cromo e } \\
\text { cálcio }\end{array}$ & $\mathrm{Ca}_{2} \mathrm{Cr}_{2} \mathrm{O}_{5}$ & 00-048-0791 & $\begin{array}{c}\text { Óxido de cromo } \\
\text { e cálcio }\end{array}$ \\
\hline & & Óxido de níquel & $\mathrm{NiO}$ & $01-089-5881$ & Óxido de níquel \\
\hline & \multirow{4}{*}{$1400^{\circ} \mathrm{C}$} & $\begin{array}{c}\text { Óxido de cromo e } \\
\text { níquel }\end{array}$ & $\mathrm{NiCr}_{2} \mathrm{O}_{4}$ & 01-075-1728 & $\begin{array}{c}\text { Óxido de cromo } \\
\text { e níquel }\end{array}$ \\
\hline & & $\begin{array}{c}\text { Óxido de cromo e } \\
\text { cálcio }\end{array}$ & $\mathrm{Ca}_{2} \mathrm{Cr}_{2} \mathrm{O}_{5}$ & 00-048-0791 & $\begin{array}{c}\text { Óxido de cromo } \\
\text { e cálcio }\end{array}$ \\
\hline & & Óxido de níquel & $\mathrm{NiO}$ & 01-089-7130 & Bunsenita, sin \\
\hline & & $\begin{array}{l}\text { Óxido de cromo e } \\
\text { bário }\end{array}$ & $\mathrm{BaCrO}_{4}$ & 01-078-1401 & $\begin{array}{c}\text { Óxido de cromo } \\
\text { e bário }\end{array}$ \\
\hline
\end{tabular}

" ICDD PDF-2, versão $2003^{80}$

O estudo das microestruturas da amostra de RSG 1 foi realizado por MEV-FEG, nos mesmos materiais tratados previamente para as análises por DRX (T amb., $110^{\circ} \mathrm{C}, 600^{\circ} \mathrm{C}, 900^{\circ} \mathrm{C}$ e $1400^{\circ} \mathrm{C}$ ). O conjunto de micrografias e microanálises químicas por EDS está apresentado nas FIG. 29 e 30.

Observa-se que entre a amostra como recebida ( $T$ amb.) e a amostra seca $\left(110^{\circ} \mathrm{C}\right)$ não há mudança na morfologia. Ambas apresentam aglomerados constituídos por partículas finas (menores que $5 \mu \mathrm{m}$ ). A partir da amostra tratada a $600^{\circ} \mathrm{C}$, observa-se alteração na morfologia, com formação de fases distintas. A microanálise química por EDS realizada na fase com formato de losango, na amostra tratada a $1400^{\circ} \mathrm{C}$ (FIG. 30), revelou uma composição rica em oxigênio, níquel e cromo, indicando que se trata provavelmente do cromato de níquel $\left(\mathrm{NiCr}_{2} \mathrm{O}_{4}\right)$ identificado por DRX. 


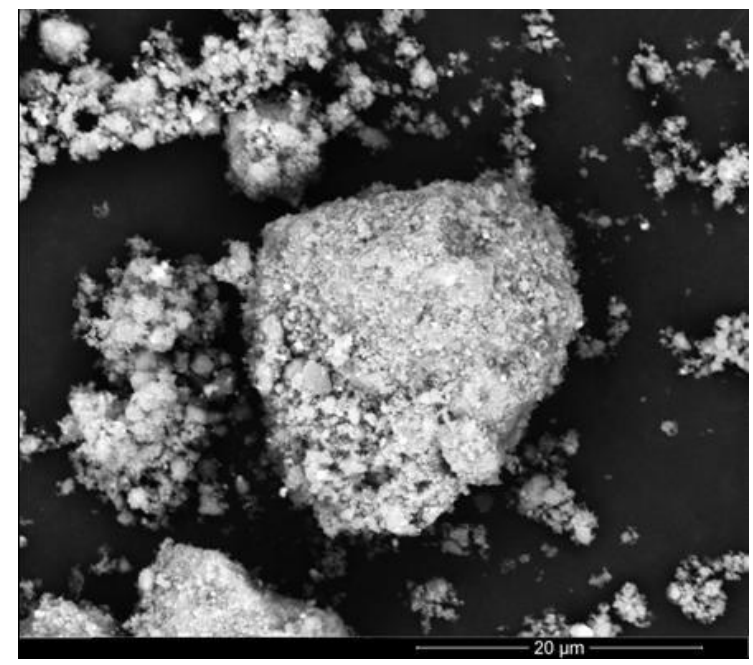

a)

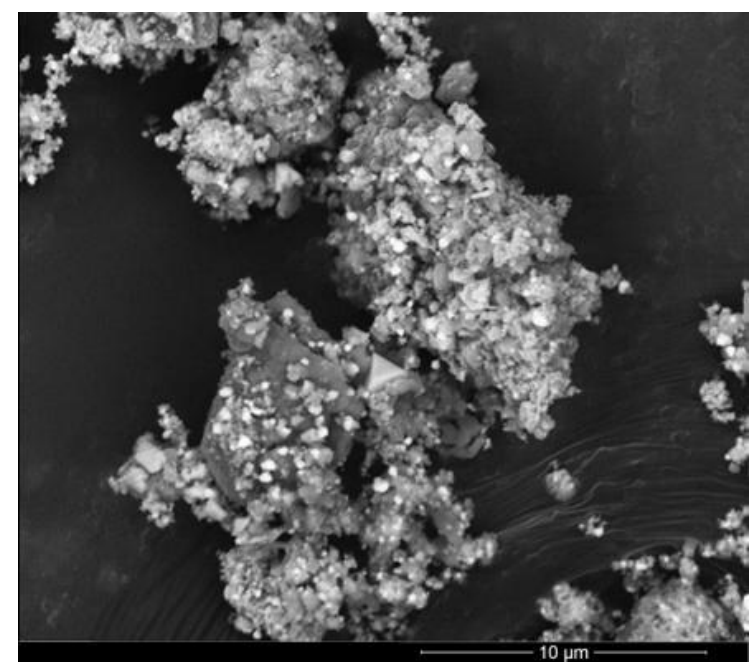

c)

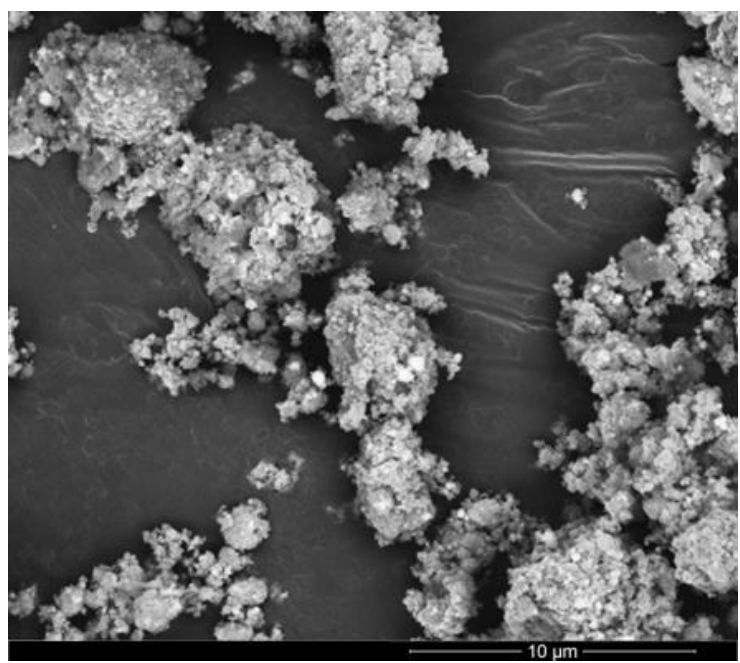

b)

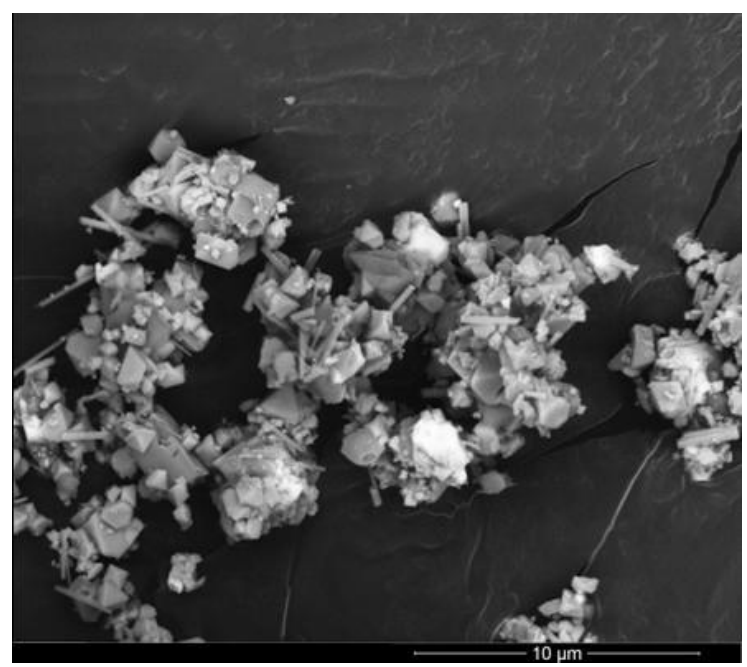

d)

FIGURA 29 - Micrografias obtidas para a amostra RSG 1 tratada a: a) T amb.; b) $110^{\circ} \mathrm{C}$; c) $600^{\circ} \mathrm{C} \mathrm{e} \mathrm{d)} 900^{\circ} \mathrm{C}$

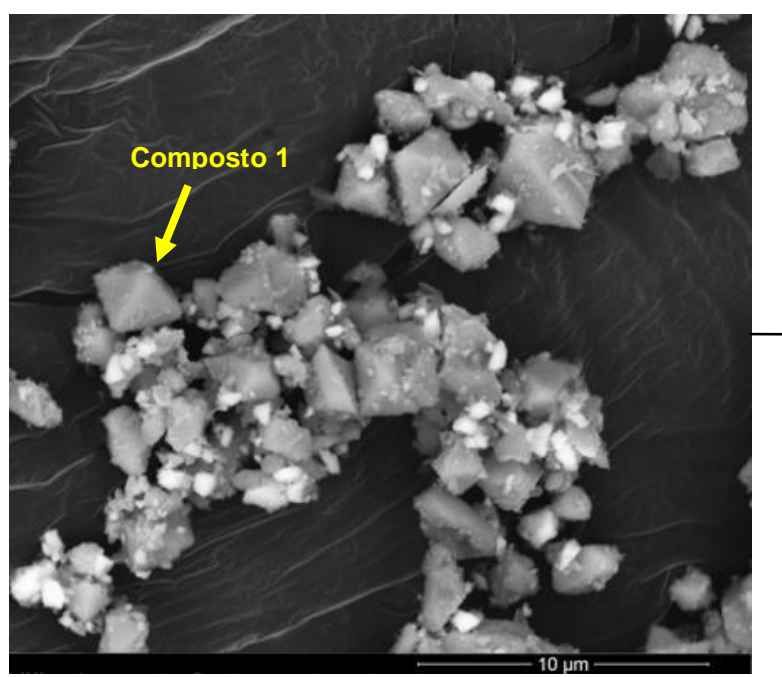

EDS (Composto 1):

$\mathrm{O}(42 \%)$

$\operatorname{Cr}(29 \%)$

$\mathrm{Ni}(11 \%)$

$\mathrm{Zn}(7 \%)$

$\mathrm{Cu}(4 \%)$

$\mathrm{Fe}(3 \%)$

C $(3 \%)$

$\mathrm{Mg}(1 \%)$

FIGURA 30 - Micrografia obtida para a amostra RSG 1 tratada a $1400^{\circ} \mathrm{C}$ e microanálise química do composto 1 
O comportamento térmico da amostra de RSG 2 (FIG. 31) é semelhante ao da amostra de RSG 1 (FIG. 27), conforme a comparação das análises por ATD e ATG. Observa-se que até a temperatura de aproximadamente $600^{\circ} \mathrm{C}$ ocorre uma perda acentuada de massa (28\%), que corresponde à perda de umidade e decomposição de carbonato de cálcio. Na curva de ATD, o pico endotérmico a $88^{\circ} \mathrm{C}$ corresponde à evaporação de água e os picos endotérmicos a $159^{\circ} \mathrm{C}$ e $374^{\circ} \mathrm{C}$ indicam, provavelmente, desidratação do sulfato de cálcio. Nas análises por DRX, apresentadas na FIG. 32, não foi observada a presença de sulfato de cálcio hidratado a $\mathrm{T}$ amb. e a $110^{\circ} \mathrm{C}$, mas, como foi identificado sulfato de cálcio anidro na amostra tratada a $600^{\circ} \mathrm{C}$, tudo indica que estes picos de ATD são relacionados à liberação de águas estruturais. Da mesma forma que para a amostra de RSG 1, o pico endotérmico a $604^{\circ} \mathrm{C}$ indica a decomposição de $\mathrm{CaCO}_{3}$, como também mostram os difratogramas, pois após tratamento a $600^{\circ} \mathrm{C}$ este composto não foi mais observado (FIG. 32). Por outro lado, diferentemente da amostra de RSG 1, a curva de perda de massa praticamente se estabiliza após a temperatura de $600^{\circ} \mathrm{C}$, apresentando um decréscimo somente no final. A perda de massa total durante o ensaio é de $38 \%$. O pico endotérmico a $766^{\circ} \mathrm{C}$ pode estar relacionado ao rearranjo de alguma estrutura envolvendo níquel ou cromo, uma vez que não há perda significativa de massa. Nas análises por DRX, observa-se que de $600^{\circ} \mathrm{C}$ para $900^{\circ} \mathrm{C}$, há mudança no tipo de óxido de níquel e no tipo de óxido de cromo e níquel formados, de acordo com as fichas de padrão de difração, apresentadas na TAB. 17. Os picos endotérmicos a $1072^{\circ} \mathrm{C}$ e $1314^{\circ} \mathrm{C}$ relacionam-se, provavelmente, à decomposição de sulfato de cálcio, como observado nos difratogramas obtidos para as amostras tratadas a $900^{\circ} \mathrm{C}$ e $1400^{\circ} \mathrm{C}$, onde a $1400^{\circ} \mathrm{C}$ não se observa mais os picos relativos a este composto. 


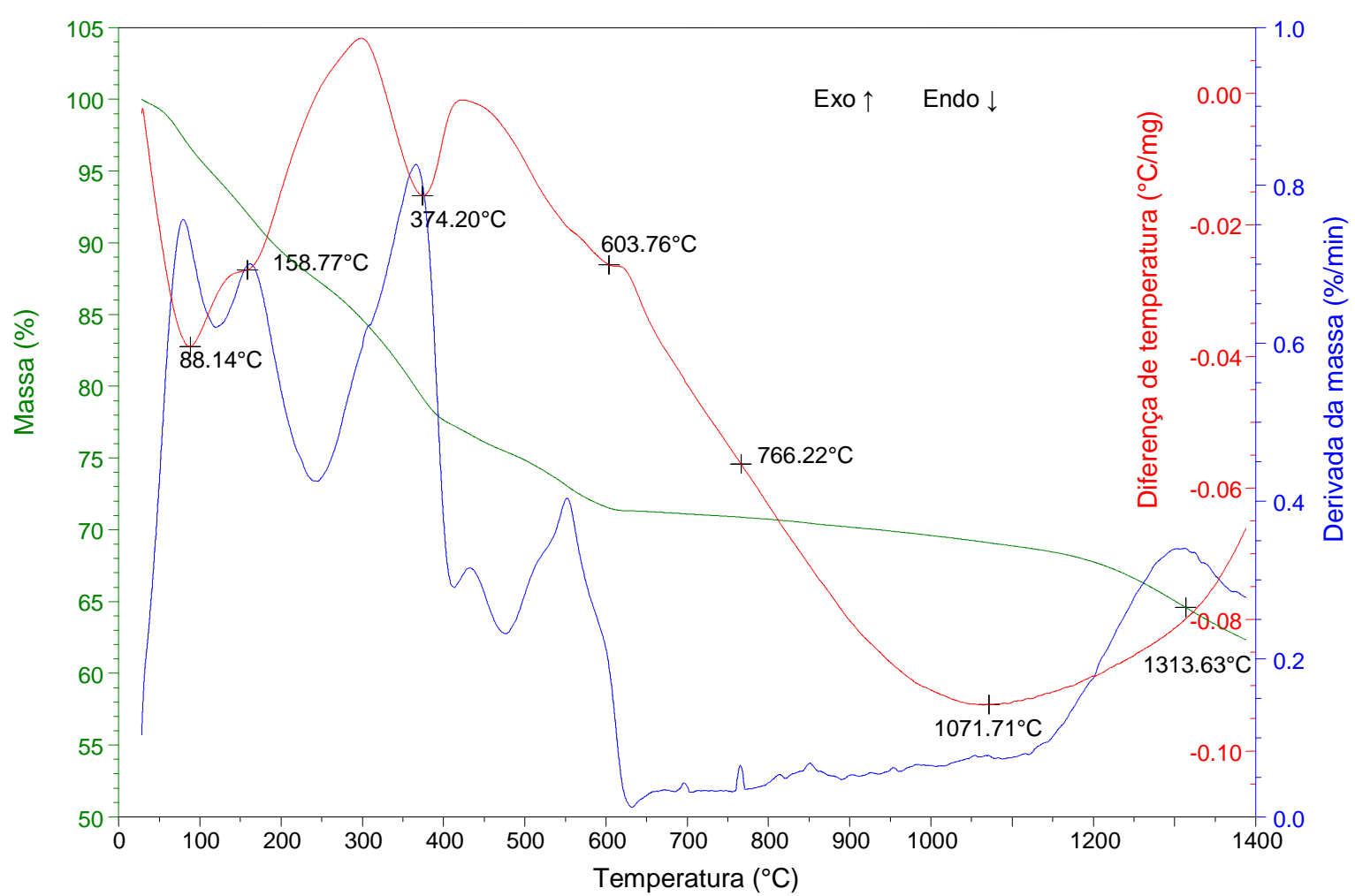

FIGURA 31 - Resultado de ATD/ATG obtido para a amostra RSG 2 (temperatura até $1400^{\circ} \mathrm{C}$, taxa de aquecimento de $10^{\circ} \mathrm{C} /$ min e atmosfera de ar sintético)
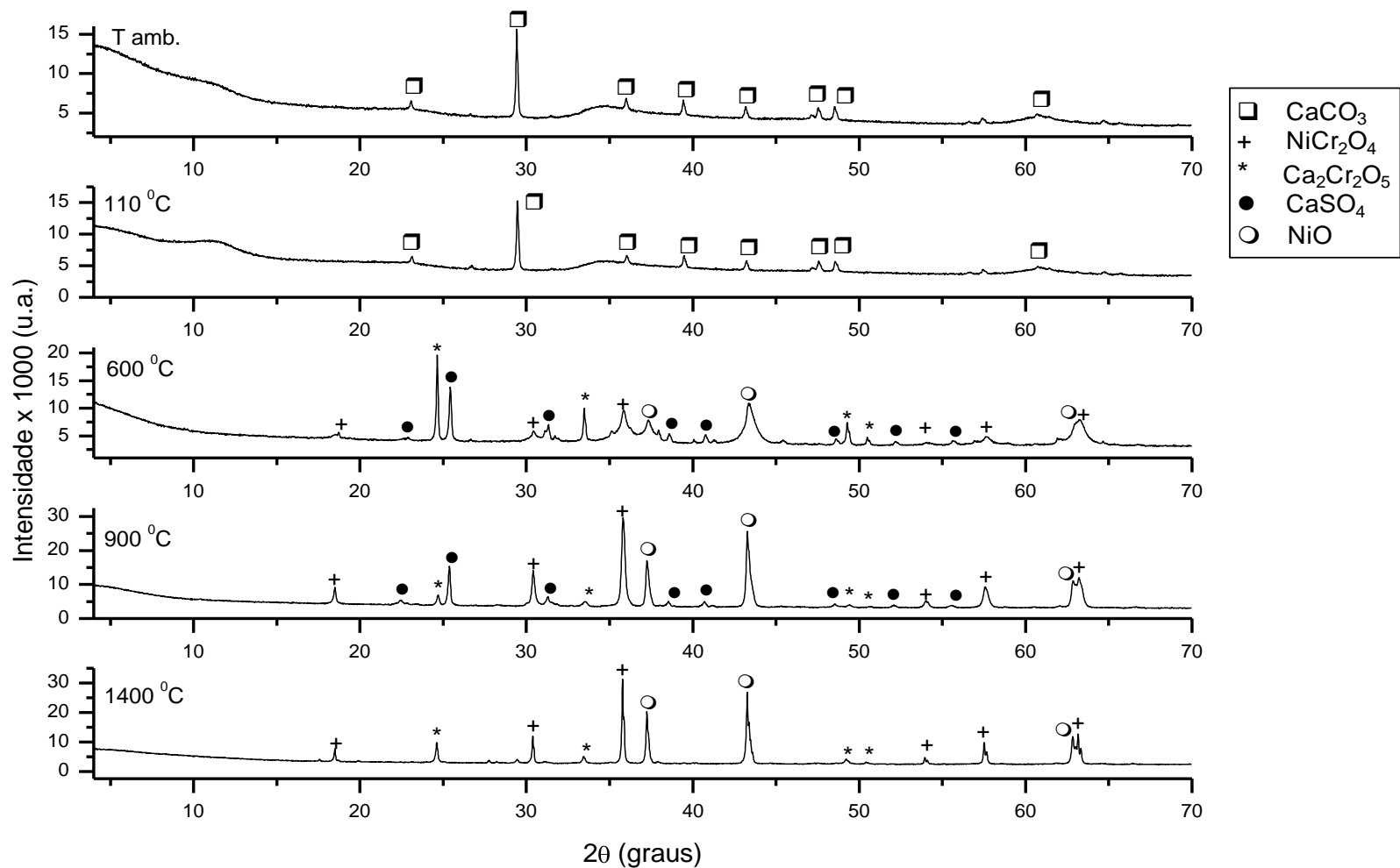

FIGURA 32 - Difratogramas obtidos para a amostra RSG 2, após tratamento em diferentes temperaturas (tubo de cobre) 
TABELA 17 - Resultado dos compostos identificados por DRX na amostra RSG 2, após tratamentos térmicos

\begin{tabular}{|c|c|c|c|c|c|}
\hline \multirow{3}{*}{ Amostra } & \multirow{3}{*}{$\begin{array}{c}\text { Tratamento } \\
\text { térmico } \\
(3 \mathrm{~h} / \mathrm{ar})\end{array}$} & \multicolumn{4}{|c|}{ Compostos } \\
\hline & & \multirow{2}{*}{ Nome } & \multirow{2}{*}{$\begin{array}{l}\text { Fórmula } \\
\text { química }\end{array}$} & \multicolumn{2}{|c|}{ Ficha de padrão de difração* } \\
\hline & & & & PDF $2^{*}$ & Nome $^{*}$ \\
\hline \multirow{13}{*}{ RSG 2} & T amb. & Carbonato de cálcio & $\mathrm{CaCO}_{3}$ & 01-083-0578 & Calcita \\
\hline & $110^{\circ} \mathrm{C}$ & Carbonato de cálcio & $\mathrm{CaCO}_{3}$ & 01-083-0578 & Calcita \\
\hline & \multirow{4}{*}{$600^{\circ} \mathrm{C}$} & Sulfato de cálcio & $\mathrm{CaSO}_{4}$ & 01-072-0916 & Anidrita \\
\hline & & $\begin{array}{c}\text { Óxido de cromo e } \\
\text { níquel }\end{array}$ & $\mathrm{NiCr}_{2} \mathrm{O}_{4}$ & 01-089-6615 & $\begin{array}{c}\text { Óxido de cromo e } \\
\text { níquel }\end{array}$ \\
\hline & & $\begin{array}{l}\text { Óxido de cromo e } \\
\text { cálcio }\end{array}$ & $\mathrm{Ca}_{2} \mathrm{Cr}_{2} \mathrm{O}_{5}$ & 00-048-0791 & $\begin{array}{c}\text { Óxido de cromo e } \\
\text { cálcio }\end{array}$ \\
\hline & & Óxido de níquel & $\mathrm{NiO}$ & 01-089-3080 & Bunsenita, sin \\
\hline & \multirow{4}{*}{$900^{\circ} \mathrm{C}$} & Sulfato de cálcio & $\mathrm{CaSO}_{4}$ & 01-072-0916 & Anidrita \\
\hline & & $\begin{array}{c}\text { Óxido de cromo e } \\
\text { níquel }\end{array}$ & $\mathrm{NiCr}_{2} \mathrm{O}_{4}$ & 01-075-1728 & $\begin{array}{c}\text { Óxido de cromo e } \\
\text { níquel }\end{array}$ \\
\hline & & $\begin{array}{l}\text { Óxido de cromo e } \\
\text { cálcio }\end{array}$ & $\mathrm{Ca}_{2} \mathrm{Cr}_{2} \mathrm{O}_{5}$ & 00-048-0791 & $\begin{array}{c}\text { Óxido de cromo e } \\
\text { cálcio }\end{array}$ \\
\hline & & Óxido de níquel & $\mathrm{NiO}$ & 01-089-5881 & Óxido de níquel \\
\hline & \multirow{3}{*}{$1400^{\circ} \mathrm{C}$} & $\begin{array}{c}\text { Óxido de cromo e } \\
\text { níquel }\end{array}$ & $\mathrm{NiCr}_{2} \mathrm{O}_{4}$ & $01-075-1728$ & $\begin{array}{c}\text { Oxido de cromo e } \\
\text { níquel }\end{array}$ \\
\hline & & $\begin{array}{l}\text { Óxido de cromo e } \\
\text { cálcio }\end{array}$ & $\mathrm{Ca}_{2} \mathrm{Cr}_{2} \mathrm{O}_{5}$ & 00-048-0791 & $\begin{array}{c}\text { Óxido de cromo e } \\
\text { cálcio }\end{array}$ \\
\hline & & Óxido de níquel & $\mathrm{NiO}$ & 01-089-5881 & Óxido de níquel \\
\hline
\end{tabular}

*ICDD PDF-2, versão $2003^{80}$

O estudo das microestruturas da amostra de RSG 2 também foi realizado por MEV-FEG, obtendo-se resultados semelhantes aos obtidos para a amostra de RSG 1, conforme apresentado nas FIG. 33, 34, 35 e 36.

Também não se observa alteração na morfologia nas duas primeiras temperaturas de tratamento, notando-se a presença de aglomerados de partículas finas. A partir da amostra tratada a $600^{\circ} \mathrm{C}$, inicia-se a formação de fases cristalinas distintas. As análises por EDS na amostra tratada a $900^{\circ} \mathrm{C}$ (FIG. $34 \mathrm{e}$ 35), revelam a presença de óxido de cromo e níquel $\left(\mathrm{NiCr}_{2} \mathrm{O}_{4}\right)$, devido às composições serem ricas em oxigênio, níquel e cromo. 


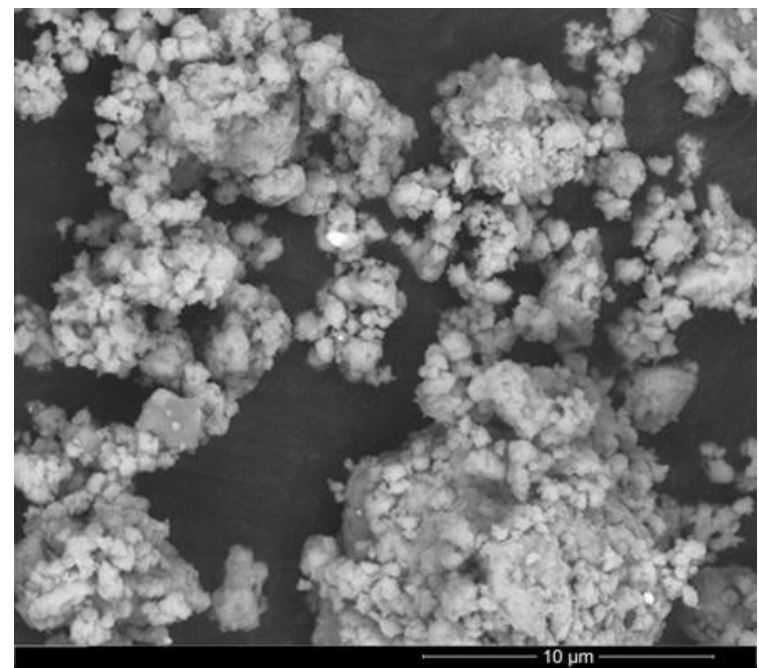

a)

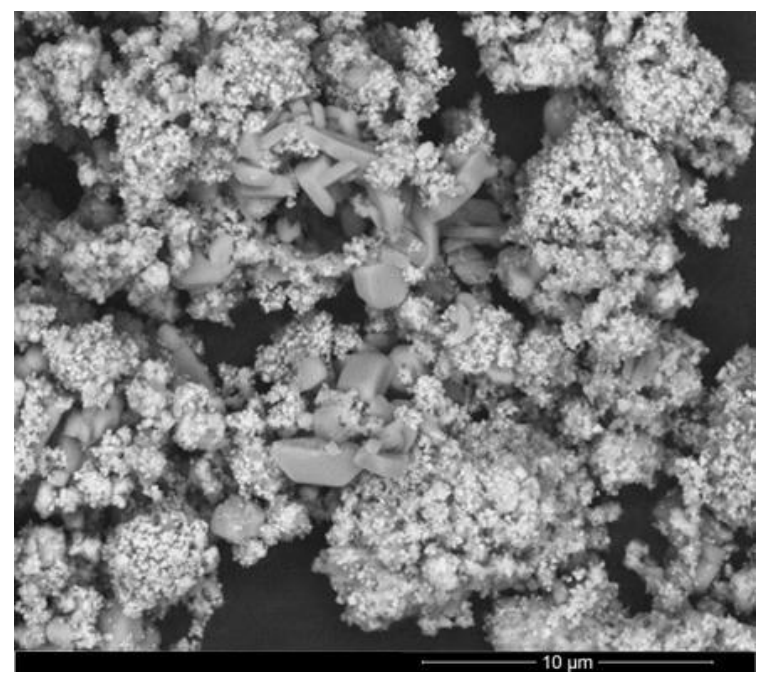

c)

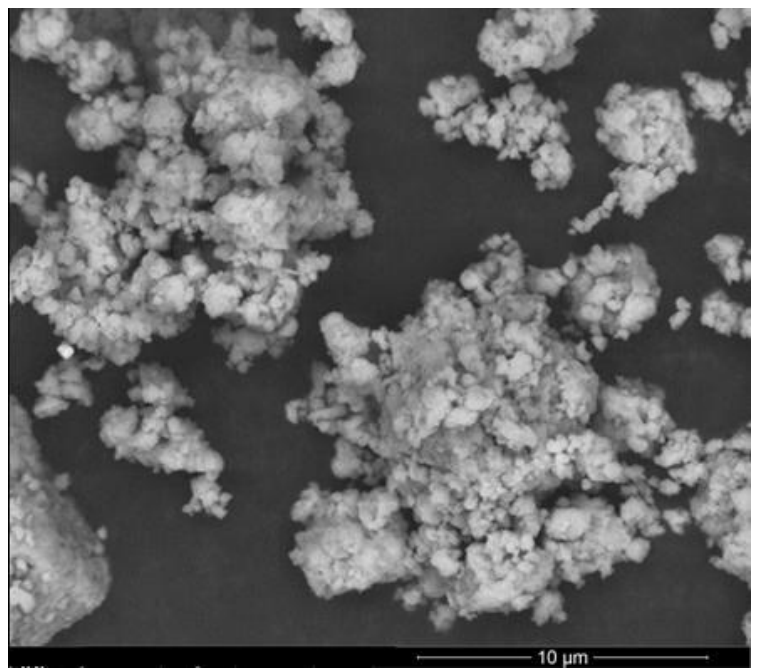

b)

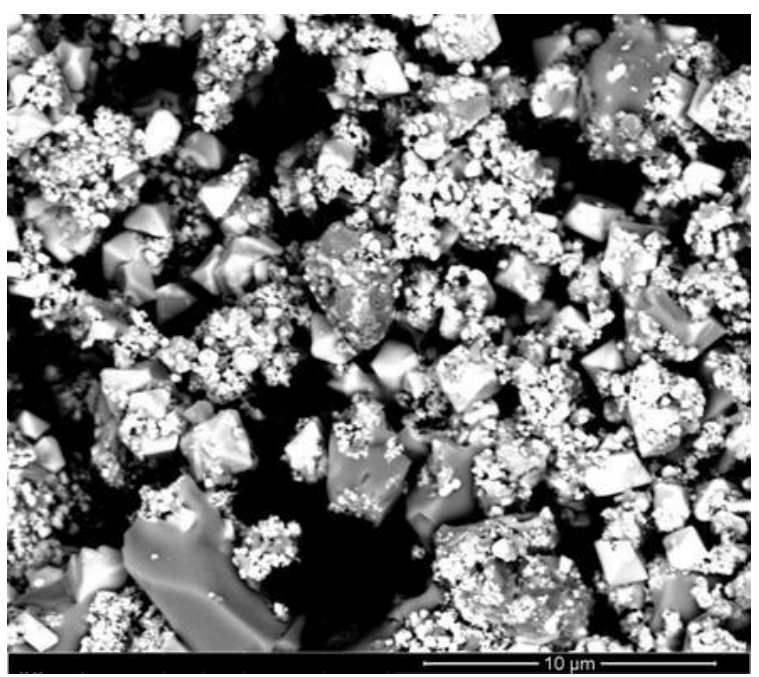

d)

FIGURA 33 - Micrografias obtidas para a amostra RSG 2 tratada a: a) T amb.; b) $110^{\circ} \mathrm{C}$; c) $600^{\circ} \mathrm{C} \mathrm{e} \mathrm{d)} 900^{\circ} \mathrm{C}$

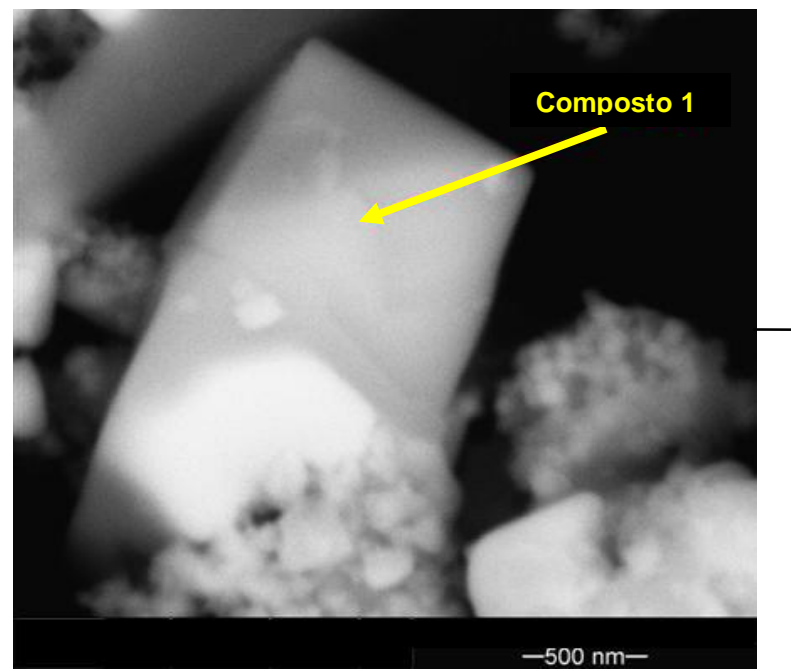

EDS (composto 1):

$\mathrm{O}(48 \%)$

$\operatorname{Cr}(26 \%)$

$\mathrm{Ni}(9 \%)$

(5\%)

$\mathrm{Zn}(5 \%)$

$\mathrm{Cu}(3 \%)$

$\mathrm{Fe}(2 \%)$

$\mathrm{Mg}(1 \%)$

$\mathrm{Ca}(1 \%)$

FIGURA 34 - Micrografia obtida para a amostra RSG 2 tratada a $900^{\circ} \mathrm{C}$ e microanálise química do composto 1 


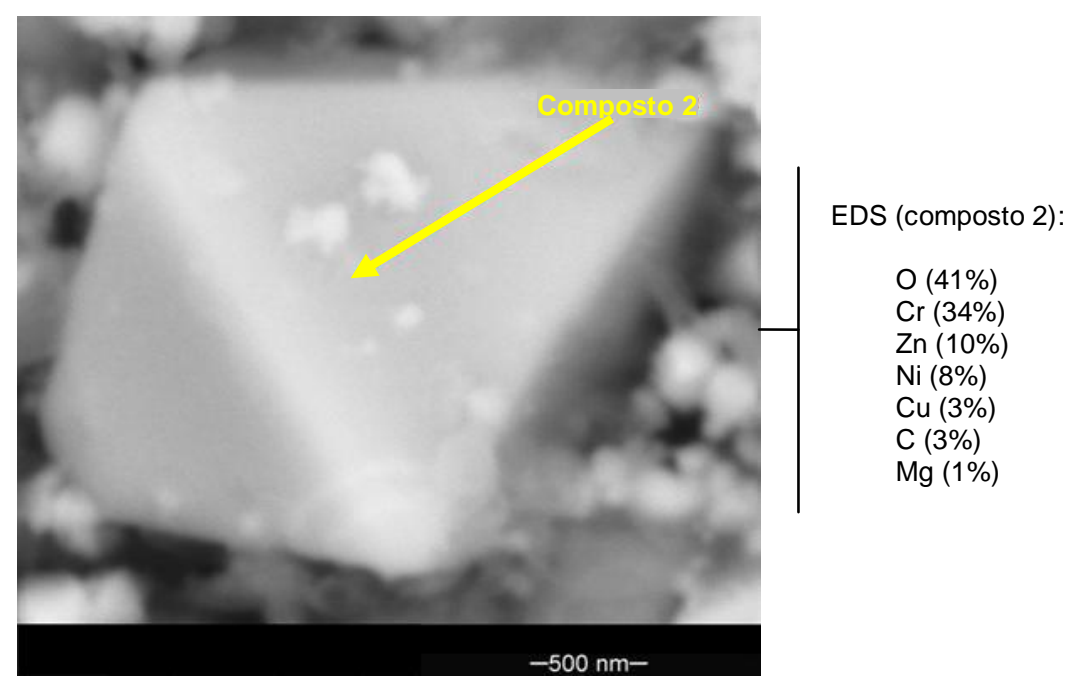

FIGURA 35 - Micrografia obtida para a amostra RSG 2 tratada a $900^{\circ} \mathrm{C}$ e microanálise química do composto 2

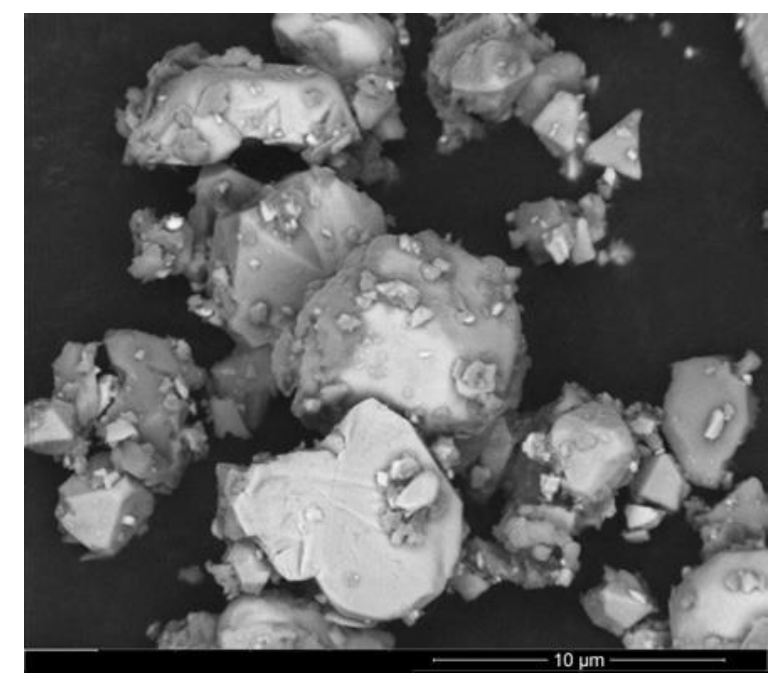

FIGURA 36 - Micrografia obtida para a amostra RSG 2 tratada a $1400^{\circ} \mathrm{C}$

O comportamento da amostra de RSG 3 com o aumento da temperatura, por meio das análises de ATD e ATG, está apresentado na FIG. 37. Observa-se que até a temperatura de aproximadamente $400^{\circ} \mathrm{C}$ ocorre uma perda acentuada de massa (20\%), principalmente, pela eliminação de água livre e combinada. O pico endotérmico a $66^{\circ} \mathrm{C}$ indica evaporação de água e os picos endotérmicos a $123^{\circ} \mathrm{C}$ e $186^{\circ} \mathrm{C}$ indicam, provavelmente, desidratação do sulfato de cálcio, conforme os resultados obtidos por DRX, apresentados na FIG. 38, onde para a amostra tratada a $600^{\circ} \mathrm{C}$ é observada somente a presença de sulfato de cálcio anidro.

Também pode ser observada a continuação da perda de massa até a temperatura máxima $\left(1400^{\circ} \mathrm{C}\right)$, totalizando $42 \%$ durante todo o ensaio. Nesta 
amostra, são observados picos exotérmicos a $303^{\circ} \mathrm{C}$ e $471^{\circ} \mathrm{C}$ nas curvas de ATD. O pico a $303^{\circ} \mathrm{C}$ está associado com uma grande perda de massa, indicando uma possível decomposição de um composto orgânico, liberado, talvez, como $\mathrm{CO}_{2}$. No pico a $471^{\circ} \mathrm{C}$, praticamente não se observa perda de massa (apenas um pequeno declínio), indicando a formação de um composto, provavelmente, com cromo, devido ao seu elevado teor na amostra. Nas análises por DRX, para a amostra tratada a $600^{\circ} \mathrm{C}$, observa-se a presença de óxido de cromo e níquel $\left(\mathrm{NiCr}_{2} \mathrm{O}_{4}\right)$, indicando que pode ter sido formado na temperatura de $471^{\circ} \mathrm{C}$.

O pico endotérmico a $812^{\circ} \mathrm{C}$ pode estar relacionado ao final da decomposição do $\mathrm{CaCO}_{3}$ ou à decomposição de outro composto, pois está associado à perda de massa. Nas análises por DRX (FIG. 38), observa-se que entre as amostras tratadas a $600^{\circ} \mathrm{C}$ e $900^{\circ} \mathrm{C}$, há o desaparecimento dos picos de óxido de silício $\left(\mathrm{SiO}_{2}\right)$ para a formação de silicato de níquel $\left(\mathrm{Ni}_{2} \mathrm{SiO}_{4}\right)$, indicando uma possível decomposição do óxido de silício a $812^{\circ} \mathrm{C}$, com posterior reordenação para a formação do silicato de níquel. O pico endotérmico a $1108^{\circ} \mathrm{C}$ também está associado à perda de massa e pode corresponder à decomposição de silicato de níquel ou mesmo de sulfato de cálcio, conforme os resultados obtidos por DRX (FIG. 38).

Nas análises de DRX, notam-se formações de compostos e diversas reordenações envolvendo cobre, conforme detalhes apresentados na TAB. 18, porém, nas análises por ATD/ATG, estes fenômenos não foram revelados. 


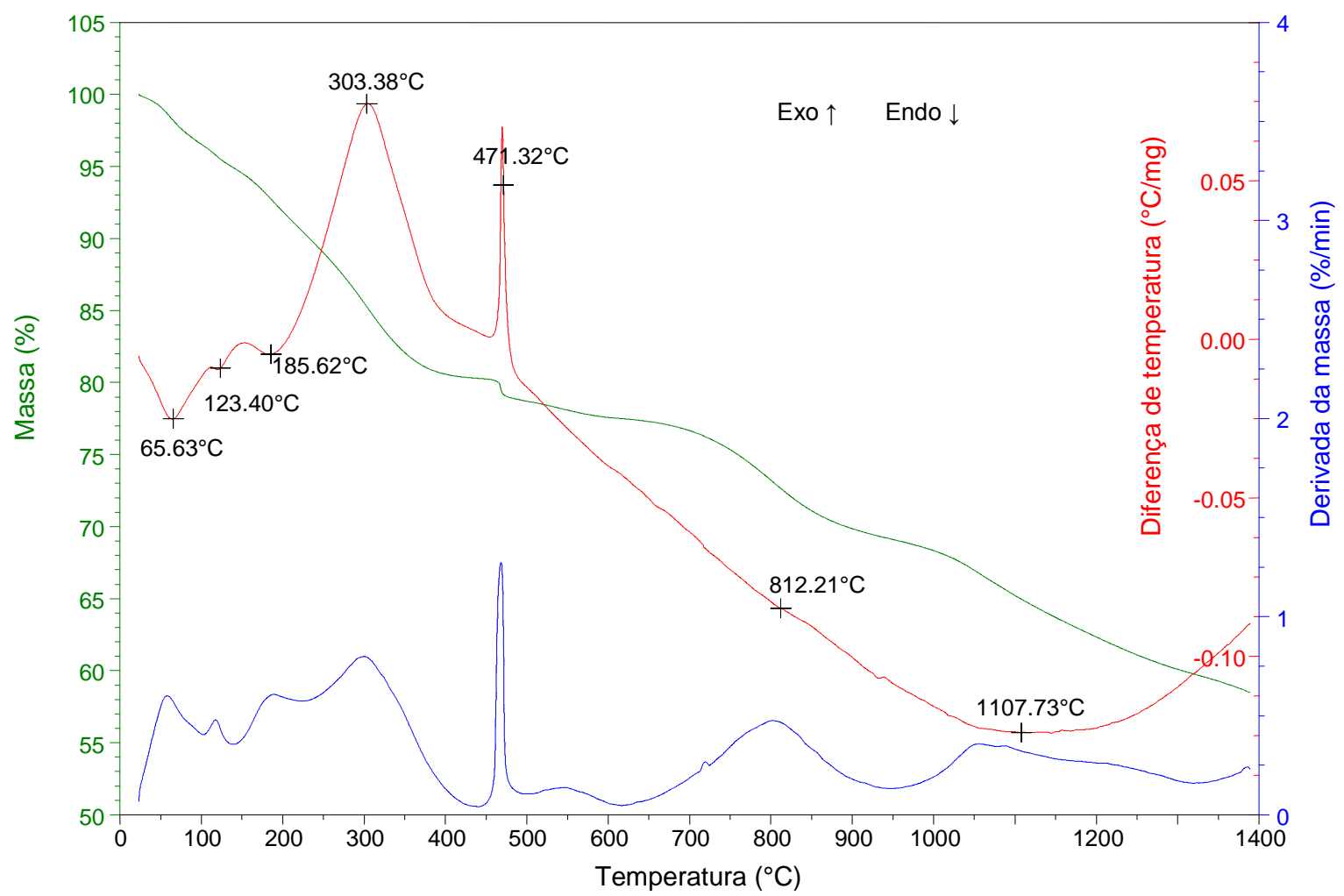

FIGURA 37 - Resultado de ATD/ATG obtido para a amostra RSG 3 (temperatura até $1400^{\circ} \mathrm{C}$, taxa de aquecimento de $10^{\circ} \mathrm{C} / \mathrm{min}$ e atmosfera de ar sintético)
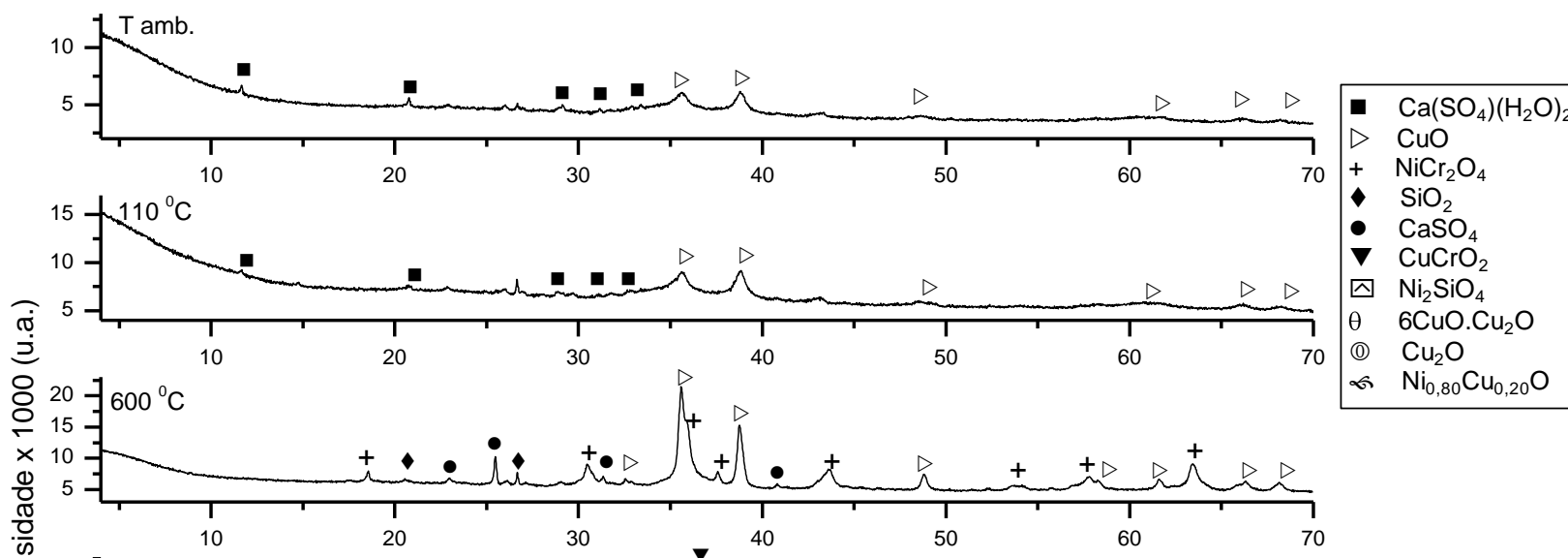

(1) $\mathrm{Cu}_{2} \mathrm{O}$

$\mathrm{Ni}_{0,80} \mathrm{Cu}_{0,20} \mathrm{O}$

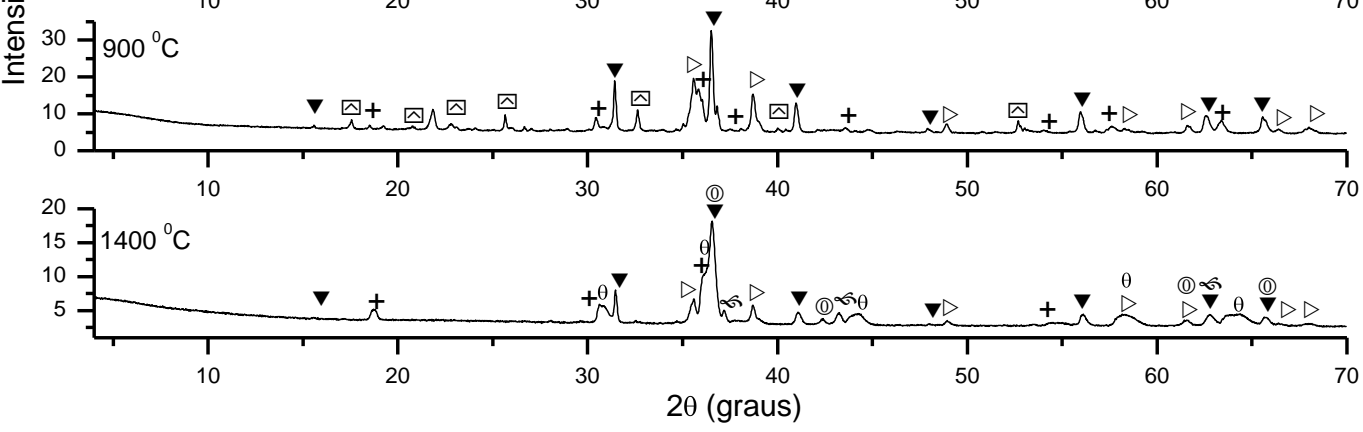

FIGURA 38 - Difratogramas obtidos para a amostra RSG 3, após tratamento em diferentes temperaturas (tubo de cobre) 
TABELA 18 - Resultado dos compostos identificados por DRX na amostra RSG 3, após tratamentos térmicos

\begin{tabular}{|c|c|c|c|c|c|}
\hline \multirow{3}{*}{ Amostra } & \multirow{3}{*}{$\begin{array}{c}\text { Tratamento } \\
\text { térmico } \\
\text { (3 h / ar) }\end{array}$} & \multicolumn{4}{|c|}{ Compostos } \\
\hline & & \multirow{2}{*}{ Nome } & \multirow{2}{*}{$\begin{array}{l}\text { Fórmula } \\
\text { química }\end{array}$} & \multicolumn{2}{|c|}{ Ficha de padrão de difração* } \\
\hline & & & & PDF 2* & Nome* \\
\hline \multirow{18}{*}{ RSG 3} & \multirow[t]{2}{*}{ T amb. } & $\begin{array}{l}\text { Sulfato de cálcio } \\
\text { hidratado }\end{array}$ & $\mathrm{Ca}\left(\mathrm{SO}_{4}\right)\left(\mathrm{H}_{2} \mathrm{O}\right)_{2}$ & 01-070-0982 & Gesso \\
\hline & & Óxido de cobre & $\mathrm{CuO}$ & 01-089-5898 & Óxido de cobre \\
\hline & \multirow{2}{*}{$110^{\circ} \mathrm{C}$} & $\begin{array}{l}\text { Sulfato de cálcio } \\
\text { hidratado }\end{array}$ & $\mathrm{Ca}\left(\mathrm{SO}_{4}\right)\left(\mathrm{H}_{2} \mathrm{O}\right)_{2}$ & 01-070-0982 & Gesso \\
\hline & & Óxido de cobre & $\mathrm{CuO}$ & 01-089-5899 & Óxido de cobre \\
\hline & \multirow{4}{*}{$600^{\circ} \mathrm{C}$} & Sulfato de cálcio & $\mathrm{CaSO}_{4}$ & 01-070-0909 & Sulfato de cálcio \\
\hline & & Óxido de cobre & $\mathrm{CuO}$ & $00-048-1548$ & Tenorita, sin \\
\hline & & Óxido de silício & $\mathrm{SiO}_{2}$ & 01-085-0796 & Quartzo \\
\hline & & $\begin{array}{c}\text { Óxido de cromo e } \\
\text { níquel }\end{array}$ & $\mathrm{NiCr}_{2} \mathrm{O}_{4}$ & 01-077-0008 & $\begin{array}{c}\text { Óxido de cromo e } \\
\text { níquel }\end{array}$ \\
\hline & \multirow{4}{*}{$900^{\circ} \mathrm{C}$} & Óxido de cobre & $\mathrm{CuO}$ & $00-089-2529$ & Tenorita, sin \\
\hline & & $\begin{array}{c}\text { Óxido de cromo e } \\
\text { níquel }\end{array}$ & $\mathrm{NiCr}_{2} \mathrm{O}_{4}$ & 01-077-0008 & $\begin{array}{c}\text { Óxido de cromo e } \\
\text { níquel }\end{array}$ \\
\hline & & $\begin{array}{c}\text { Óxido de silício e } \\
\text { níquel }\end{array}$ & $\mathrm{Ni}_{2} \mathrm{SiO}_{4}$ & 01-076-1502 & Silicato de níquel \\
\hline & & $\begin{array}{c}\text { Óxido de cromo e } \\
\text { cobre }\end{array}$ & $\mathrm{CuCrO}_{2}$ & 01-089-6744 & $\begin{array}{c}\begin{array}{c}\text { Óxido de cromo e } \\
\text { cobre }\end{array} \\
\end{array}$ \\
\hline & \multirow{6}{*}{$1400^{\circ} \mathrm{C}$} & Óxido de cobre & $\mathrm{CuO}$ & $00-089-2529$ & Tenorita, sin \\
\hline & & $\begin{array}{c}\text { Óxido de cromo e } \\
\text { níquel }\end{array}$ & $\mathrm{NiCr}_{2} \mathrm{O}_{4}$ & 01-077-0008 & $\begin{array}{c}\text { Óxido de cromo e } \\
\text { níquel }\end{array}$ \\
\hline & & $\begin{array}{c}\text { Óxido de cromo e } \\
\text { cobre }\end{array}$ & $\mathrm{CuCrO}_{2}$ & $01-089-6744$ & $\begin{array}{c}\text { Óxido de cromo e } \\
\text { cobre }\end{array}$ \\
\hline & & Óxido de cobre I & $\mathrm{Cu}_{2} \mathrm{O}$ & 01-077-0199 & Cuprita, sin \\
\hline & & $\begin{array}{c}\text { Óxido de cobre e } \\
\text { níquel }\end{array}$ & $\mathrm{Ni}_{0,80} \mathrm{Cu}_{0,20} \mathrm{O}$ & $01-078-0647$ & $\begin{array}{c}\text { Óxido de cobre e } \\
\text { níquel }\end{array}$ \\
\hline & & $\begin{array}{c}\text { Óxido de cobre } \\
\text { I e II }\end{array}$ & $6 \mathrm{CuO} \cdot \mathrm{Cu}_{2} \mathrm{O}$ & 00-003-0879 & Paramelaconita \\
\hline
\end{tabular}

* ICDD PDF-2, versão $2003^{80}$

O estudo das microestruturas da amostra de RSG 3 foi realizado por MEV-FEG e os resultados obtidos estão apresentados nas FIG. 39, 40, 41 e 42.

Aglomerados de partículas finas são verificados nas três primeiras temperaturas de tratamento, porém, observa-se a formação de fases cristalinas desde a primeira micrografia.

A partir da amostra tratada a $900^{\circ} \mathrm{C}$, nota-se a formação de novas fases cristalinas, bem definidas. Microanálises químicas por EDS foram realizadas nas amostras tratadas a $900^{\circ} \mathrm{C}$ e $1400^{\circ} \mathrm{C}$ e os resultados obtidos mostraram que, para a amostra tratada a $900^{\circ} \mathrm{C}$ (FIG. 40), o composto 1 pode ser formado por 
óxido de cromo e níquel $\left(\mathrm{NiCr}_{2} \mathrm{O}_{4}\right)$ ou óxido de cromo e cobre $\left(\mathrm{CuCrO}_{2}\right)$; o composto 2 pode ser formado por óxido de cromo e cobre ou óxido de cobre $(\mathrm{CuO})$ e o composto 3 é provavelmente óxido de cobre. Já para a amostra tratada a $1400^{\circ} \mathrm{C}$ (FIG. 42), o composto 1 apresenta uma fase contendo silício, não identificada por DRX; o composto 2 pode ser formado por óxido de cromo e níquel ou óxido de cromo e cobre e os compostos 3 e 4 são provavelmente óxido de cobre.

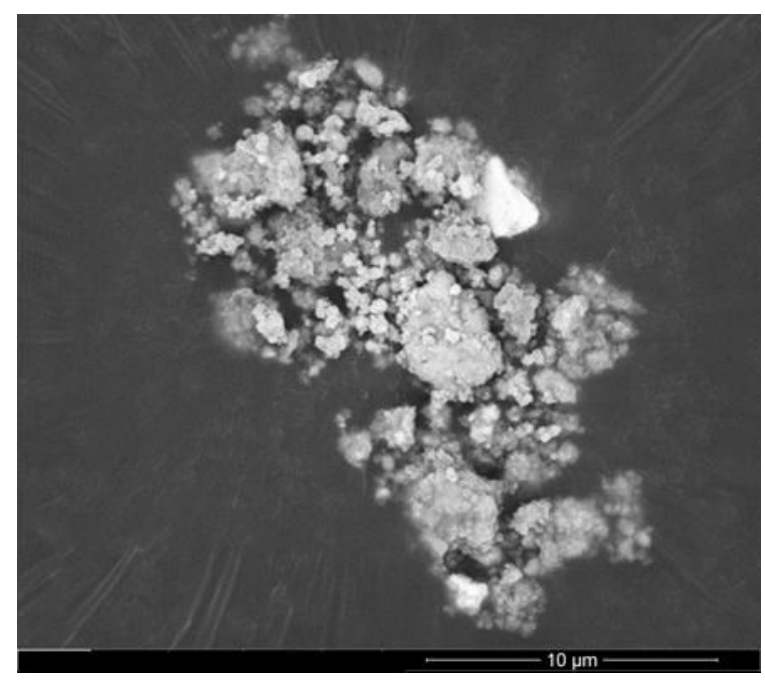

a)

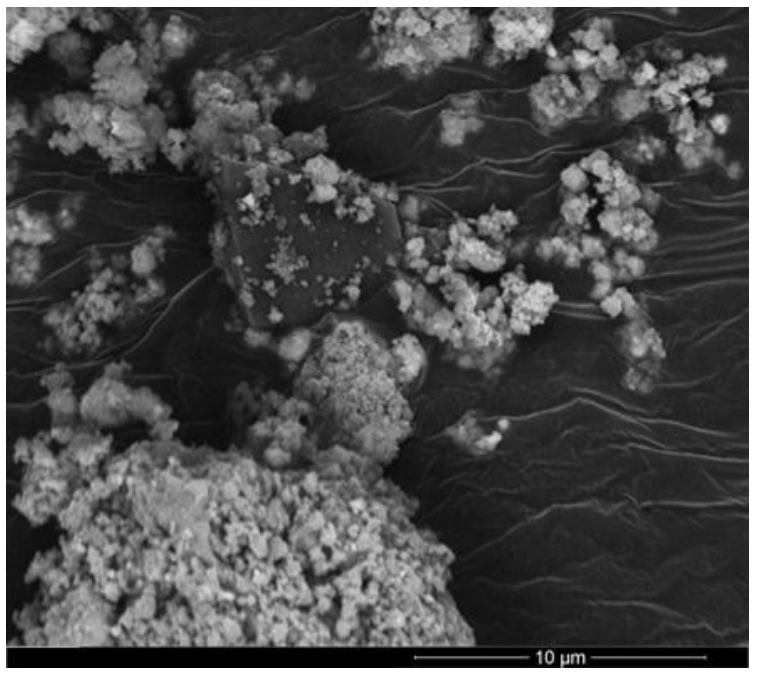

b)

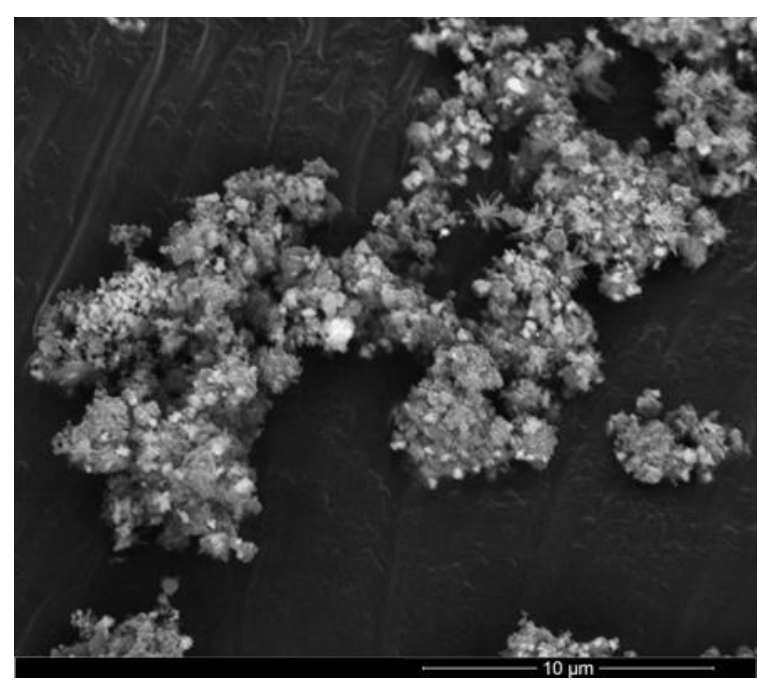

c)

FIGURA 39 - Micrografias obtidas para a amostra RSG 3 tratada a: a) T amb.; b) $110^{\circ} \mathrm{C}$ e c) $600^{\circ} \mathrm{C}$ 


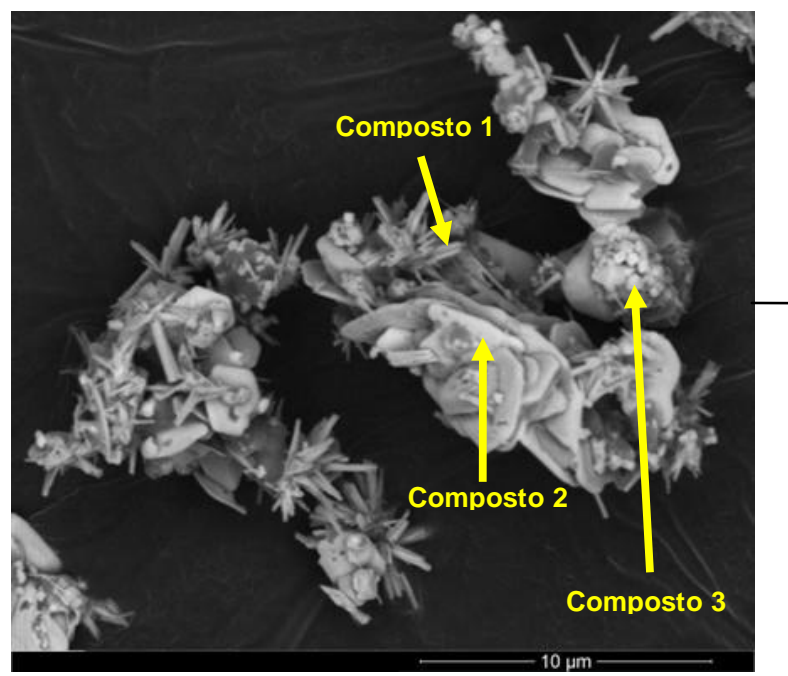

EDS:

Composto 1 Composto 2 Composto 3

$\begin{array}{lll}\mathrm{O}(33 \%) & \mathrm{O}(38 \%) & \mathrm{Cu}(57 \%) \\ \mathrm{C}(29 \%) & \mathrm{C}(23 \%) & \mathrm{O}(33 \%) \\ \mathrm{Ni}(12 \%) & \mathrm{Cu}(21 \%) & \mathrm{C}(7 \%) \\ \mathrm{Cr}(10 \%) & \mathrm{Cr}(12 \%) & \mathrm{Cr}(2 \%) \\ \mathrm{Cu}(10 \%) & \mathrm{Si}(2 \%) & \mathrm{Si}(1 \%) \\ \mathrm{Si}(2 \%) & \mathrm{Ni}(2 \%) & \\ \mathrm{Fe}(2 \%) & \mathrm{Fe}(1 \%) & \\ \mathrm{S}(1 \%) & \mathrm{Al}(1 \%) & \\ \mathrm{Ca}(1 \%) & & \end{array}$

FIGURA 40 - Micrografia obtida para a amostra RSG 3 tratada a $900^{\circ} \mathrm{C}$ e microanálise química dos compostos 1,2 e 3

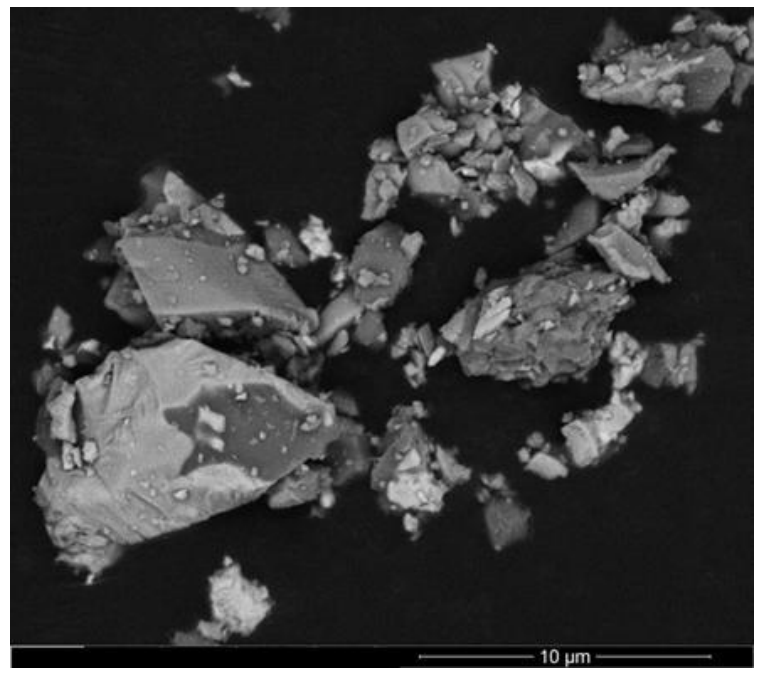

FIGURA 41 - Micrografia obtida para a amostra RSG 3 tratada a $1400^{\circ} \mathrm{C}$

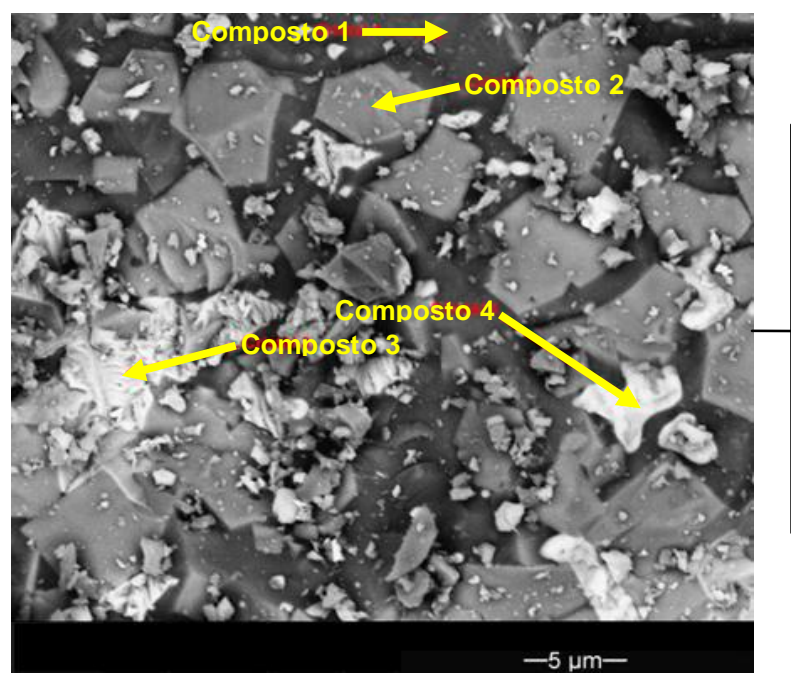

EDS:

Composto 1 Composto 2 Composto 3 Composto 4

$\begin{array}{llll}\mathrm{O}(61 \%) & \mathrm{O}(48 \%) & \mathrm{Cu}(72 \%) & \mathrm{Cu}(90 \%) \\ \mathrm{Si}(18 \%) & \mathrm{Cr}(24 \%) & \mathrm{O}(27 \%) & \mathrm{O}(10 \%) \\ \mathrm{Al}(6 \%) & \mathrm{Ni}(11 \%) & \mathrm{Cr}(1 \%) & \\ \mathrm{Ca}(6 \%) & \mathrm{Cu}(8 \%) & & \\ \mathrm{P}(4 \%) & \mathrm{Al}(6 \%) & & \\ \mathrm{Na}(3 \%) & \mathrm{Fe}(2 \%) & & \\ \mathrm{Cu}(2 \%) & \mathrm{Si}(1 \%) & & \end{array}$

FIGURA 42 - Micrografia obtida para a amostra RSG 3 tratada a $1400^{\circ} \mathrm{C}$ e microanálise química dos compostos 1, 2, 3 e 4 
A curva de ATD da amostra de RSG 4 (FIG. 43) apresenta um comportamento semelhante à da amostra de RSG 3 (FIG. 37), com a diferença do pico exotérmico a $506^{\circ} \mathrm{C}$ (próximo ao pico a $471^{\circ} \mathrm{C}$, para o RSG 3) ter menor intensidade, sendo este pico o que indica provavelmente a formação de $\mathrm{NiCr}_{2} \mathrm{O}_{4}$. O teor de cromo na amostra de RSG 4 é menor, o que pode ter causado esta diminuição no pico e o não aparecimento dos picos relativos a este composto no difratograma para a amostra tratada a $600^{\circ} \mathrm{C}$ (FIG. 44).

Ainda na FIG.43, observa-se que até a temperatura de aproximadamente $700^{\circ} \mathrm{C}$ ocorre uma perda acentuada de massa (22\%), que corresponde à perda de umidade e decomposição de carbonato de cálcio. O pico endotérmico a $58^{\circ} \mathrm{C}$ indica evaporação de água e os picos endotérmicos a $116^{\circ} \mathrm{C}$ e $168^{\circ} \mathrm{C}$ indicam, provavelmente, desidratação do sulfato de cálcio, conforme os resultados obtidos por DRX, apresentados na FIG. 44, onde na amostra tratada a $600^{\circ} \mathrm{C}$, é observada somente a presença de sulfato de cálcio anidro. Da mesma forma que para a amostra de RSG 3, o pico exotérmico a $311^{\circ} \mathrm{C}$ indica uma possível decomposição de composto orgânico, liberado, talvez, como $\mathrm{CO}_{2}$. O pico endotérmico a $411^{\circ} \mathrm{C}$ indica a decomposição de $\mathrm{CaCO}_{3}$, também observada nos difratogramas, pois a partir de $600^{\circ} \mathrm{C}$ este composto não é mais visualizado (FIG. 44).

A curva de perda de massa nesta amostra apresenta uma estabilização após a temperatura de $700^{\circ} \mathrm{C}$. No entanto, a partir de aproximadamente $1100^{\circ} \mathrm{C}$ começa a decrescer novamente, resultando em uma perda de massa de $19 \%$ até o final. A perda de massa total durante o ensaio é de $43 \%$. Os picos endotérmicos a $606^{\circ} \mathrm{C}, 655^{\circ} \mathrm{C}$ e $877^{\circ} \mathrm{C}$ podem estar relacionados ao término da decomposição do $\mathrm{CaCO}_{3}$ ou ao rearranjo de alguma estrutura envolvendo níquel, cálcio ou cromo, uma vez que estes elementos estão presentes em elevados teores na amostra e a massa é praticamente constante. O pico endotérmico a $975^{\circ} \mathrm{C}$ é, provavelmente, correspondente à decomposição de sulfato de cálcio, pois no difratograma obtido para a amostra tratada a $1400^{\circ} \mathrm{C}$, não mais se observa os picos relativos a este composto. Por fim, os discretos picos exotérmicos a 1243 e $1344^{\circ} \mathrm{C}$ indicam possíveis fusões associadas a uma elevada perda de massa, mas as análises por DRX, para as amostras tratadas a $900^{\circ} \mathrm{C}$ e $1400^{\circ} \mathrm{C}$, não apontaram variações significativas. Segundo a literatura ${ }^{79}$, os cromatos de níquel 
e de cálcio presentes na amostra são estáveis até temperaturas superiores a $2000^{\circ} \mathrm{C}$ e o óxido de níquel é estável até aproximadamente $1980^{\circ} \mathrm{C}$.

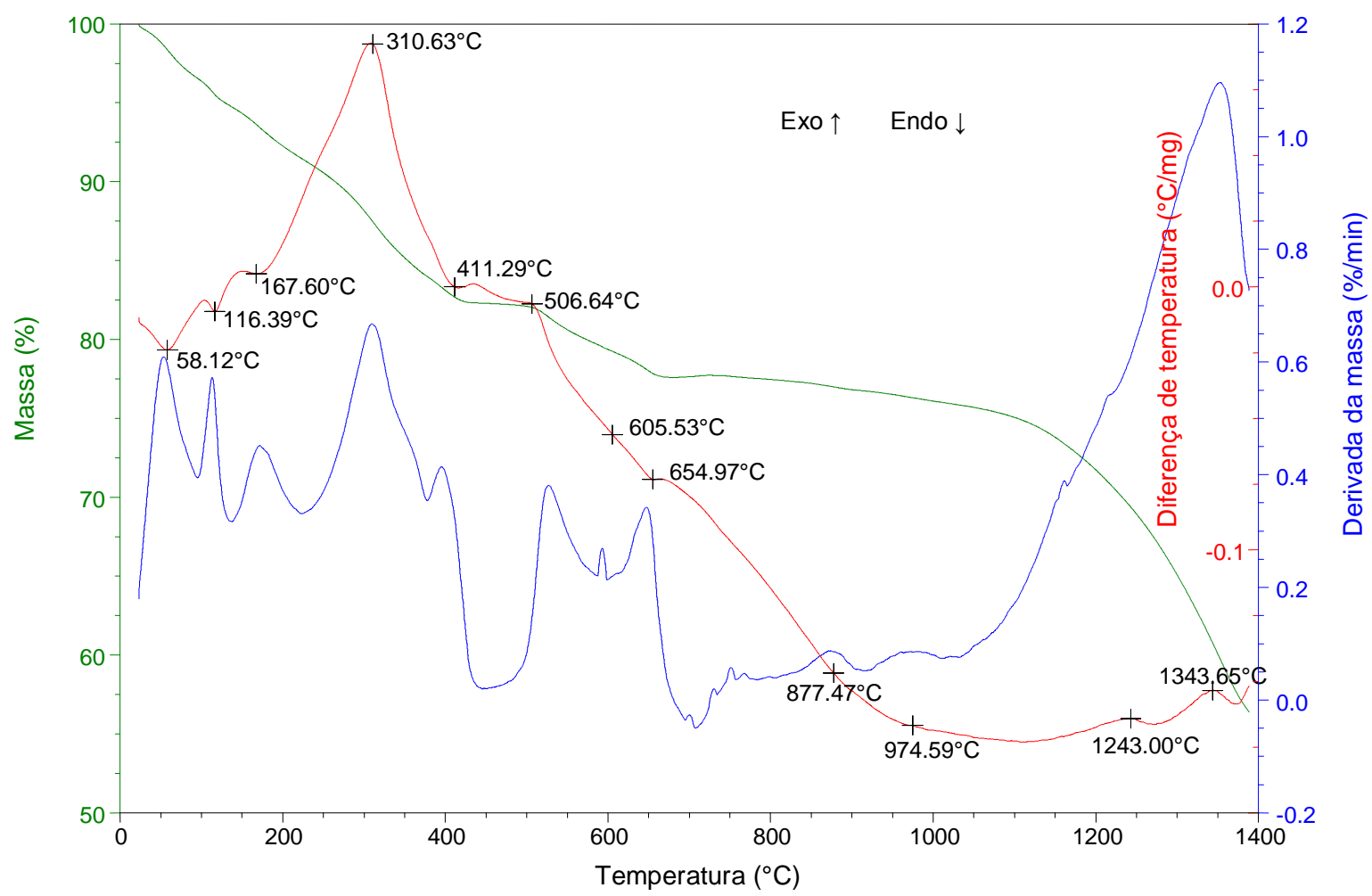

FIGURA 43 - Resultado de ATD/ATG obtido para a amostra RSG 4 (temperatura até $1400^{\circ} \mathrm{C}$, taxa de aquecimento de $10^{\circ} \mathrm{C} / \mathrm{min}$ e atmosfera de ar sintético)
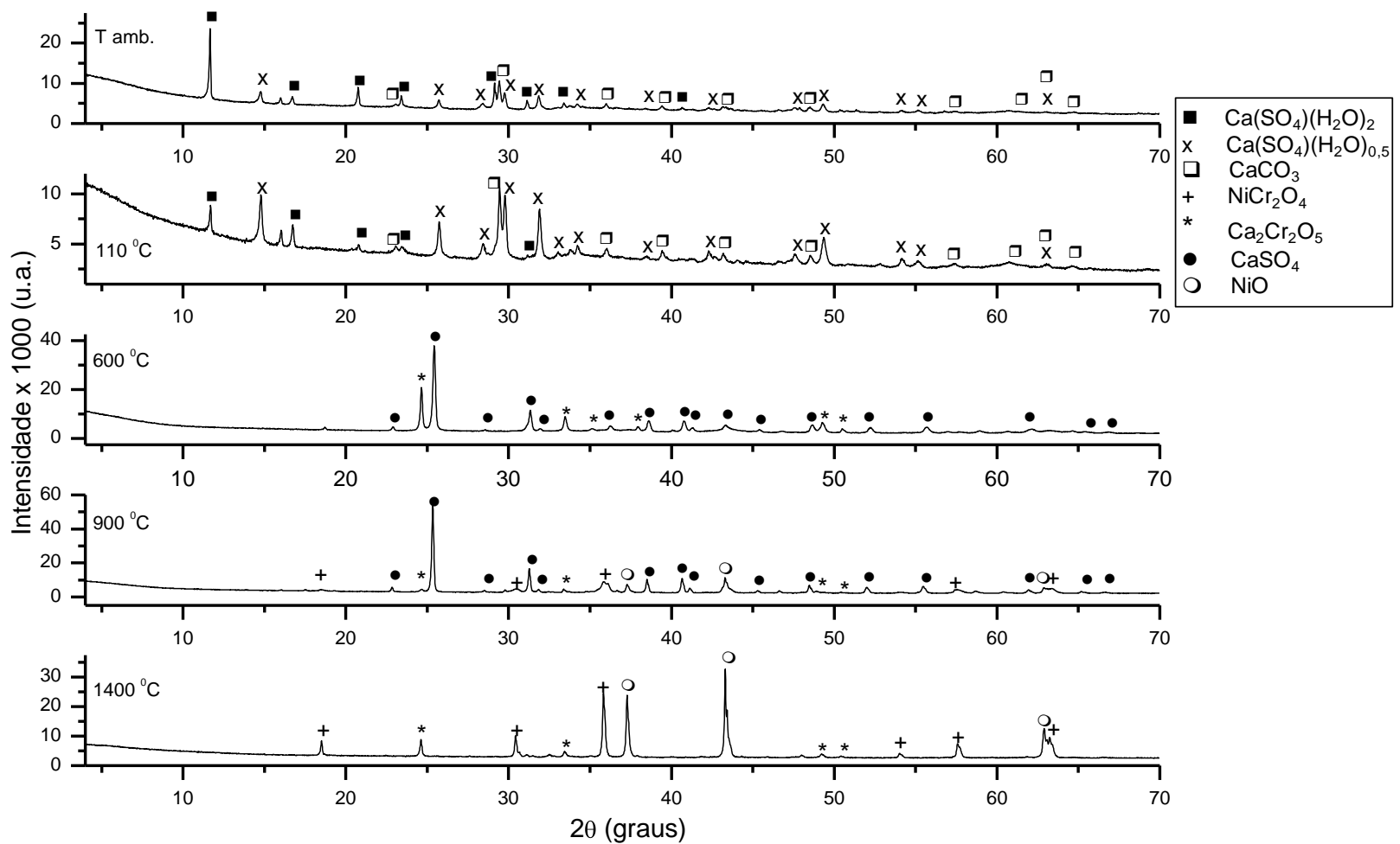

FIGURA 44 - Difratogramas obtidos para a amostra RSG 4, após tratamento em diferentes temperaturas (tubo de cobre) 
A TAB. 19 apresenta todas as formações de compostos e reordenações obtidas nas análises por DRX, para a amostra de RSG 4.

TABELA 19 - Resultado dos compostos identificados por DRX na amostra RSG 4, após tratamentos térmicos

\begin{tabular}{|c|c|c|c|c|c|}
\hline \multirow{3}{*}{ Amostra } & \multirow{3}{*}{$\begin{array}{c}\text { Tratamento } \\
\text { térmico } \\
(3 \mathrm{~h} / \text { ar) }\end{array}$} & \multicolumn{4}{|c|}{ Compostos } \\
\hline & & \multirow{2}{*}{ Nome } & \multirow{2}{*}{$\begin{array}{l}\text { Fórmula } \\
\text { química }\end{array}$} & \multicolumn{2}{|c|}{ Ficha de padrão de difração* } \\
\hline & & & & PDF 2* & Nome* \\
\hline \multirow{15}{*}{ RSG 4} & \multirow{3}{*}{ T amb. } & \multirow{2}{*}{$\begin{array}{l}\text { Sulfato de cálcio } \\
\text { hidratado }\end{array}$} & $\mathrm{Ca}\left(\mathrm{SO}_{4}\right)\left(\mathrm{H}_{2} \mathrm{O}\right)_{2}$ & $01-074-1433$ & Gesso \\
\hline & & & $\mathrm{Ca}\left(\mathrm{SO}_{4}\right)\left(\mathrm{H}_{2} \mathrm{O}\right)_{0,5}$ & 01-081-1849 & $\begin{array}{l}\text { Sulfato de cálcic } \\
\text { hidratado }\end{array}$ \\
\hline & & $\begin{array}{l}\text { Carbonato de } \\
\text { cálcio }\end{array}$ & $\mathrm{CaCO}_{3}$ & 01-083-0578 & Calcita \\
\hline & \multirow{3}{*}{$110^{\circ} \mathrm{C}$} & \multirow{2}{*}{$\begin{array}{l}\text { Sulfato de cálcio } \\
\text { hidratado }\end{array}$} & $\mathrm{Ca}\left(\mathrm{SO}_{4}\right)\left(\mathrm{H}_{2} \mathrm{O}\right)_{2}$ & $01-076-1746$ & Gesso \\
\hline & & & $\mathrm{Ca}\left(\mathrm{SO}_{4}\right)\left(\mathrm{H}_{2} \mathrm{O}\right)_{0,5}$ & 01-081-1849 & $\begin{array}{l}\text { Sulfato de cálcic } \\
\text { hidratado }\end{array}$ \\
\hline & & $\begin{array}{l}\text { Carbonato de } \\
\text { cálcio }\end{array}$ & $\mathrm{CaCO}_{3}$ & 01-083-0578 & Calcita \\
\hline & \multirow[b]{2}{*}{$600^{\circ} \mathrm{C}$} & Sulfato de cálcio & $\mathrm{CaSO}_{4}$ & 01-072-0916 & Anidrita \\
\hline & & $\begin{array}{c}\text { Óxido de cromo e } \\
\text { cálcio }\end{array}$ & $\mathrm{Ca}_{2} \mathrm{Cr}_{2} \mathrm{O}_{5}$ & $00-048-0791$ & $\begin{array}{c}\text { Óxido de cromo } \\
\text { e cálcio }\end{array}$ \\
\hline & \multirow{4}{*}{$900^{\circ} \mathrm{C}$} & Sulfato de cálcio & $\mathrm{CaSO}_{4}$ & $01-072-0916$ & Anidrita \\
\hline & & $\begin{array}{l}\text { Óxido de cromo e } \\
\text { cálcio }\end{array}$ & $\mathrm{Ca}_{2} \mathrm{Cr}_{2} \mathrm{O}_{5}$ & 00-048-0791 & $\begin{array}{c}\text { Óxido de cromo } \\
\text { e cálcio }\end{array}$ \\
\hline & & $\begin{array}{c}\text { Óxido de cromo e } \\
\text { níquel }\end{array}$ & $\mathrm{NiCr}_{2} \mathrm{O}_{4}$ & $01-089-6615$ & $\begin{array}{c}\text { Óxido de cromo } \\
\text { e níquel }\end{array}$ \\
\hline & & Óxido de níquel & $\mathrm{NiO}$ & $01-089-5881$ & Óxido de níquel \\
\hline & \multirow{3}{*}{$1400^{\circ} \mathrm{C}$} & $\begin{array}{c}\text { Óxido de cromo e } \\
\text { cálcio }\end{array}$ & $\mathrm{Ca}_{2} \mathrm{Cr}_{2} \mathrm{O}_{5}$ & 00-048-0791 & $\begin{array}{c}\text { Óxido de cromo } \\
\text { e cálcio }\end{array}$ \\
\hline & & $\begin{array}{c}\text { Óxido de cromo e } \\
\text { níquel }\end{array}$ & $\mathrm{NiCr}_{2} \mathrm{O}_{4}$ & 01-089-6615 & $\begin{array}{c}\text { Óxido de cromo } \\
\text { e níquel }\end{array}$ \\
\hline & & Óxido de níquel & $\mathrm{NiO}$ & $01-089-5881$ & Óxido de níquel \\
\hline
\end{tabular}

*ICDD PDF-2, versão $2003^{80}$

O estudo das microestruturas da amostra de RSG 4 também foi realizado por MEV-FEG e os resultados obtidos estão apresentados nas FIG. 45, 46, 47 e 48.

A morfologia entre a amostra como recebida (T amb.), a amostra seca $\left(110^{\circ} \mathrm{C}\right)$ e a amostra tratada a $600^{\circ} \mathrm{C}$ não se altera, caracterizando-se pela presença de aglomerados de partículas finas.

Após tratamento térmico a $900^{\circ} \mathrm{C}$, nota-se a formação de fases cristalinas distintas, principalmente, no formato de agulhas (aciculares), mas também em outras formas geométricas (FIG. 46). A análise por EDS revela que 0 
composto 1 é provavelmente óxido de cromo e níquel $\left(\mathrm{NiCr}_{2} \mathrm{O}_{4}\right)$, também podendo ser óxido de cromo e cálcio $\left(\mathrm{Ca}_{2} \mathrm{Cr}_{2} \mathrm{O}_{5}\right)$; o composto 2 é provavelmente sulfato de cálcio e o composto 3 é provavelmente óxido de níquel, também podendo ser óxido de cromo e níquel $\left(\mathrm{NiCr}_{2} \mathrm{O}_{4}\right)$ ou óxido de cromo e cálcio $\left(\mathrm{Ca}_{2} \mathrm{Cr}_{2} \mathrm{O}_{5}\right)$.

Após o tratamento térmico a $1400^{\circ} \mathrm{C}$, são identificadas fases características e algumas foram analisadas por EDS (FIG. 48). Os resultados obtidos revelaram que os compostos 1 e 2 podem ser óxido de cromo e níquel $\left(\mathrm{NiCr}_{2} \mathrm{O}_{4}\right)$ ou óxido de níquel (NiO) e os compostos 3 e 4 podem ser óxido de cromo e níquel $\left(\mathrm{NiCr}_{2} \mathrm{O}_{4}\right)$ ou óxido de cromo e cálcio $\left(\mathrm{Ca}_{2} \mathrm{Cr}_{2} \mathrm{O}_{5}\right)$.

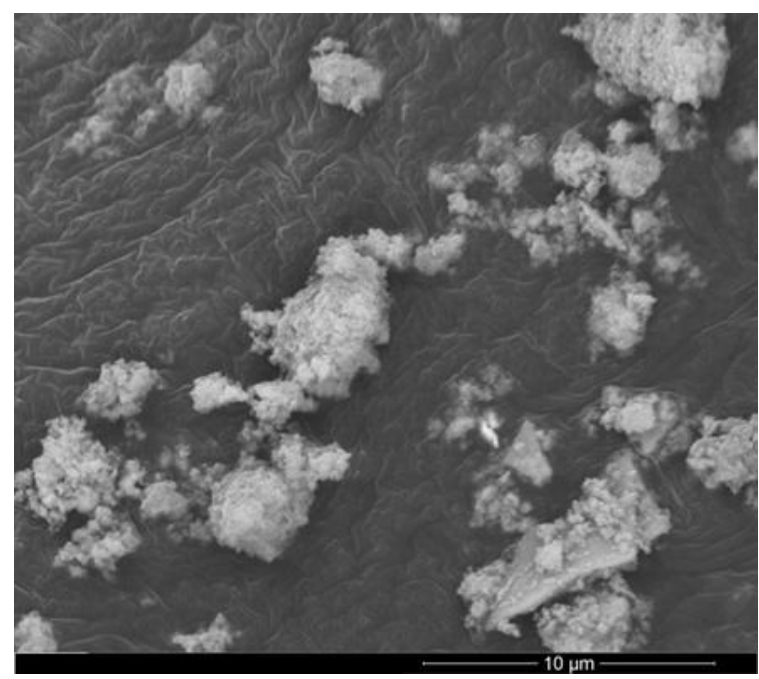

a)

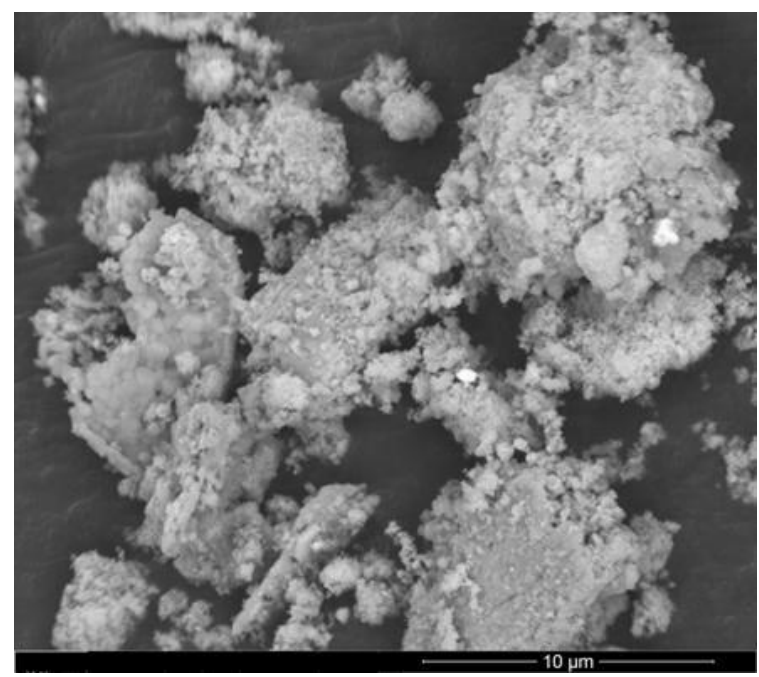

c)

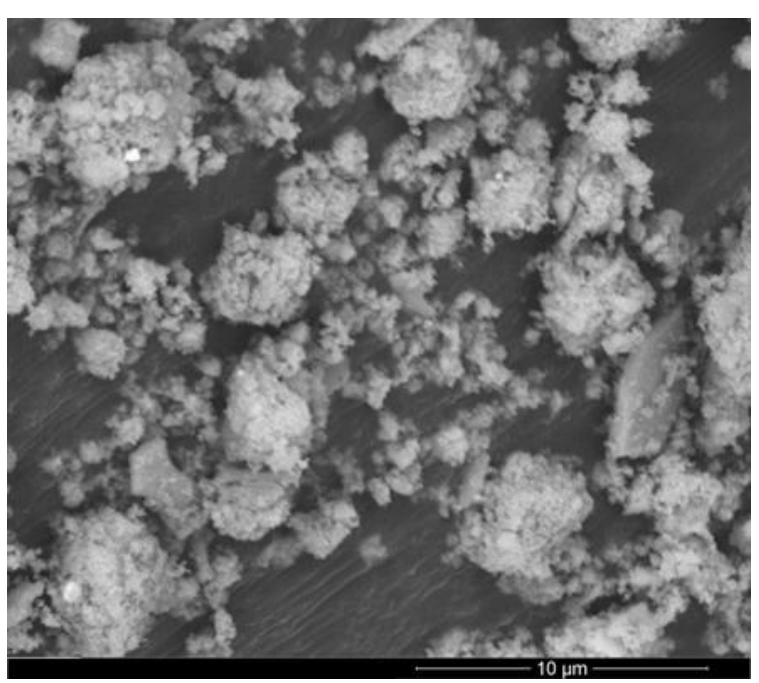

b)

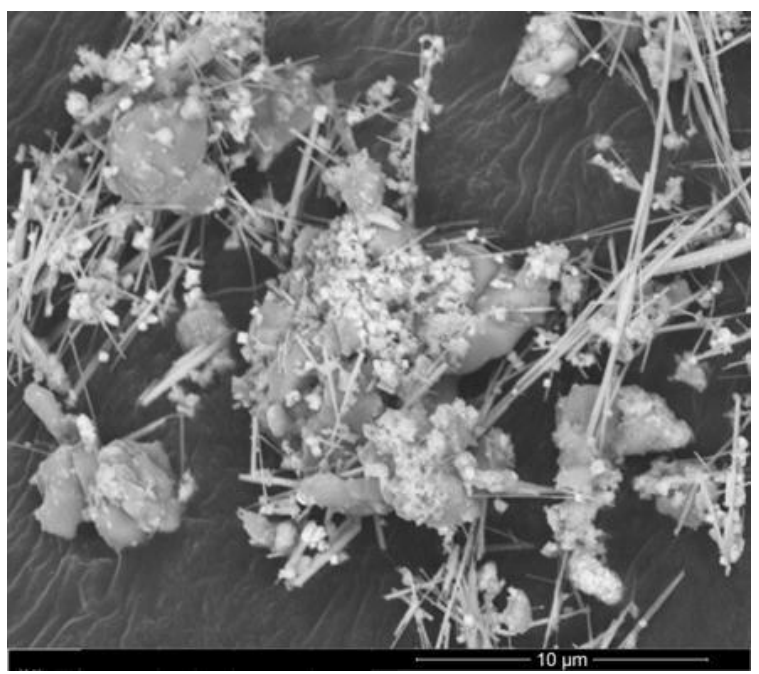

d)

FIGURA 45 - Micrografias obtidas para a amostra RSG 4 tratada a: a) T amb.; b) $110^{\circ} \mathrm{C}$; c) $\left.600^{\circ} \mathrm{C} \mathrm{e} \mathrm{d}\right) 900^{\circ} \mathrm{C}$ 


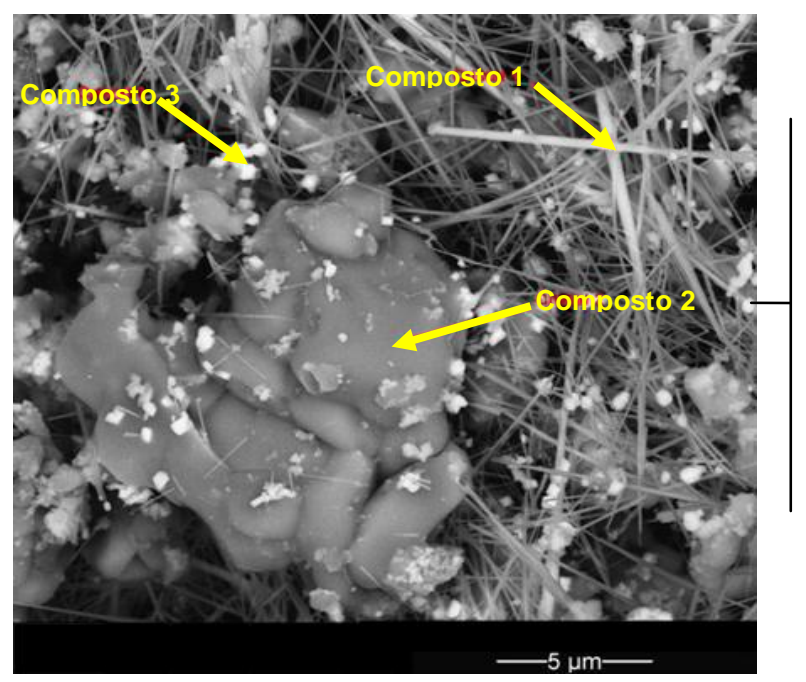

EDS:

$\begin{array}{lll}\text { Composto 1 } & \text { Composto 2 } & \text { Composto 3 } \\ \mathrm{O}(54 \%) & \mathrm{O}(62 \%) & \mathrm{Ni}(45 \%) \\ \mathrm{Ni}(25 \%) & \mathrm{Ca}(18 \%) & \mathrm{O}(45 \%) \\ \mathrm{Cr}(13 \%) & \mathrm{S}(16 \%) & \mathrm{Cr}(5 \%) \\ \mathrm{Ca}(4 \%) & \mathrm{Cr}(4 \%) & \mathrm{Ca}(3 \%) \\ \mathrm{S}(2 \%) & & \mathrm{S}(2 \%) \\ \mathrm{Mg}(1 \%) & & \\ \mathrm{Si}(1 \%) & & \end{array}$

FIGURA 46 - Micrografia obtida para a amostra RSG 4 tratada a $900^{\circ} \mathrm{C}$ e microanálise química dos compostos 1,2 e 3

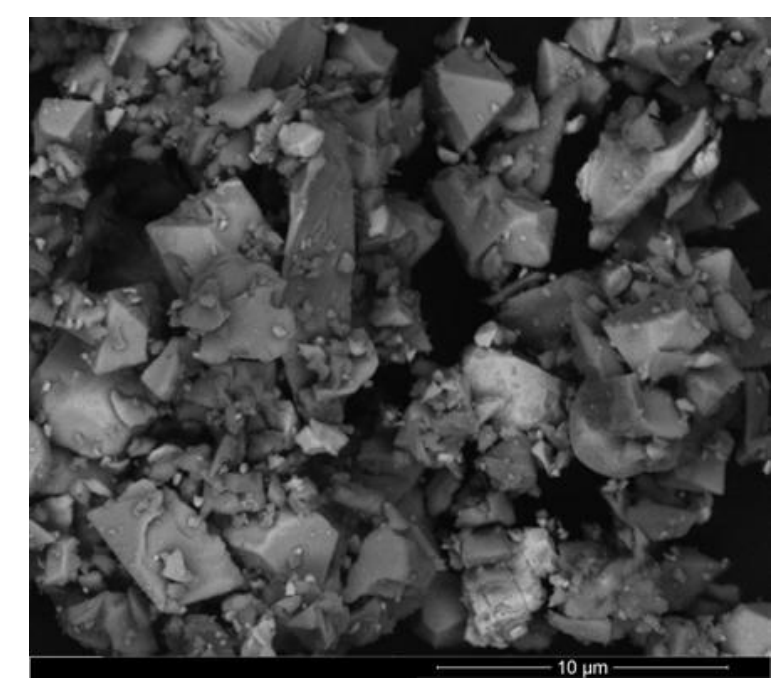

FIGURA 47 - Micrografia obtida para a amostra RSG 4 tratada a $1400^{\circ} \mathrm{C}$

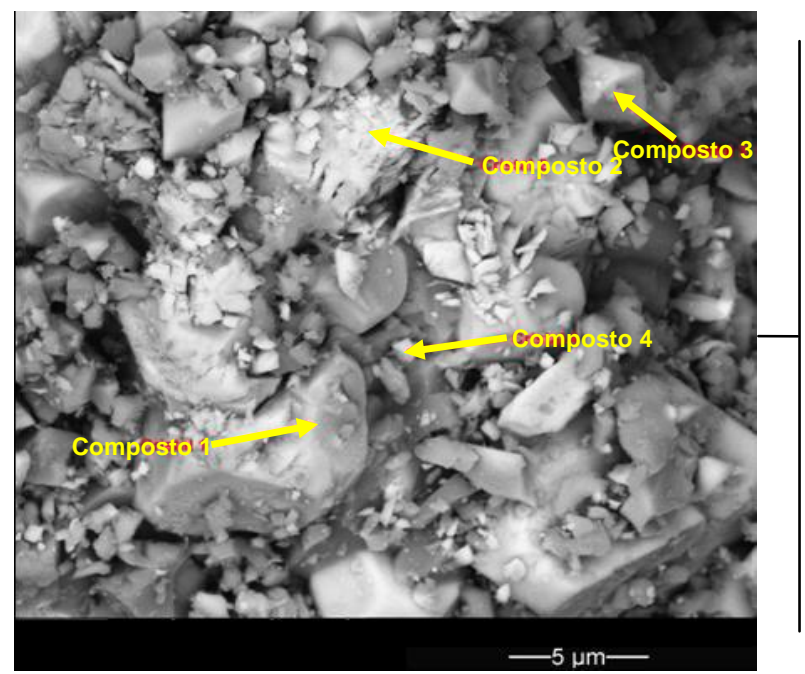

EDS:

$\begin{array}{cc}\text { Composto 1 } & \text { Composto 2 } \\ \mathrm{Ni}(72 \%) & \mathrm{Ni}(62 \%) \\ \mathrm{O}(16 \%) & \mathrm{O}(32 \%) \\ \mathrm{Cr}(8 \%) & \mathrm{Cr}(5 \%) \\ \mathrm{Ca}(4 \%) & \mathrm{Ca}(1 \%)\end{array}$

Composto $3 \quad$ Composto 4

$\mathrm{Cr}(31 \%) \quad \mathrm{Ni}(34 \%)$

$\mathrm{Ni}(20 \%) \quad \mathrm{Cr}(33 \%)$

$\mathrm{C}(18 \%) \quad \mathrm{Fe}(13 \%)$

$\mathrm{O}(14 \%) \quad \mathrm{Ca}(10 \%)$

$\mathrm{Fe}(8 \%) \quad \mathrm{O}(10 \%)$

FIGURA 48 - Micrografia obtida para a amostra RSG 4 tratada a $1400^{\circ} \mathrm{C}$ e microanálise química dos compostos 1, 2, 3 e 4 
A amostra de RSG 5 apresenta um comportamento diferente das demais amostras, devido ao processo produtivo da empresa $n^{\circ} 5$ ser de douração/latonagem. Nas análises realizadas por ATD/ATG, apresentadas na FIG. 49, observa-se que com o aumento da temperatura até aproximadamente $300^{\circ} \mathrm{C}$ ocorre uma perda de massa acentuada (16\%), principalmente, pela eliminação de água livre e combinada. O pico endotérmico a $66^{\circ} \mathrm{C}$ indica evaporação de água e os picos endotérmicos a $195^{\circ} \mathrm{C}$ e $288^{\circ} \mathrm{C}$ indicam, provavelmente, desidratação da butgembachita identificada por DRX (FIG. 50) e decomposição de hidróxido de cobre $\left[\mathrm{Cu}(\mathrm{OH})_{2}\right]$ e hidróxido de níquel $\left[\mathrm{Ni}(\mathrm{OH})_{2}\right]$, cujos pontos de decomposição ocorrem entre $230^{\circ} \mathrm{C}$ e $250^{\circ} \mathrm{C}$, segundo a litertura ${ }^{79}$.

Entre $300^{\circ} \mathrm{C}$ e $1050^{\circ} \mathrm{C}$ observa-se uma estabilização da curva de perda de massa e a $1066^{\circ} \mathrm{C}$ pode ser observado, na curva de ATD, o início de um fenômeno de fusão, provavelmente, envolvendo cobre. Pela literatura ${ }^{79}$, a cuprita $\left(\mathrm{Cu}_{2} \mathrm{O}\right)$ apresenta ponto de fusão a $1235^{\circ} \mathrm{C}$ e a tenorita $(\mathrm{CuO})$ apresenta ponto de fusão a $1326^{\circ} \mathrm{C}$. A elevada energia liberada durante esta reação causou o rompimento do cadinho, provocando, provavelmente, a queda brusca da curva de perda de massa após $1050^{\circ} \mathrm{C}$.

Nas análises de DRX, nas várias temperaturas, observam-se diversas reordenações envolvendo cobre e níquel, conforme detalhes apresentados na TAB. 20, porém, nas análises por ATD/ATG, estes fenômenos não foram plenamente identificados. 


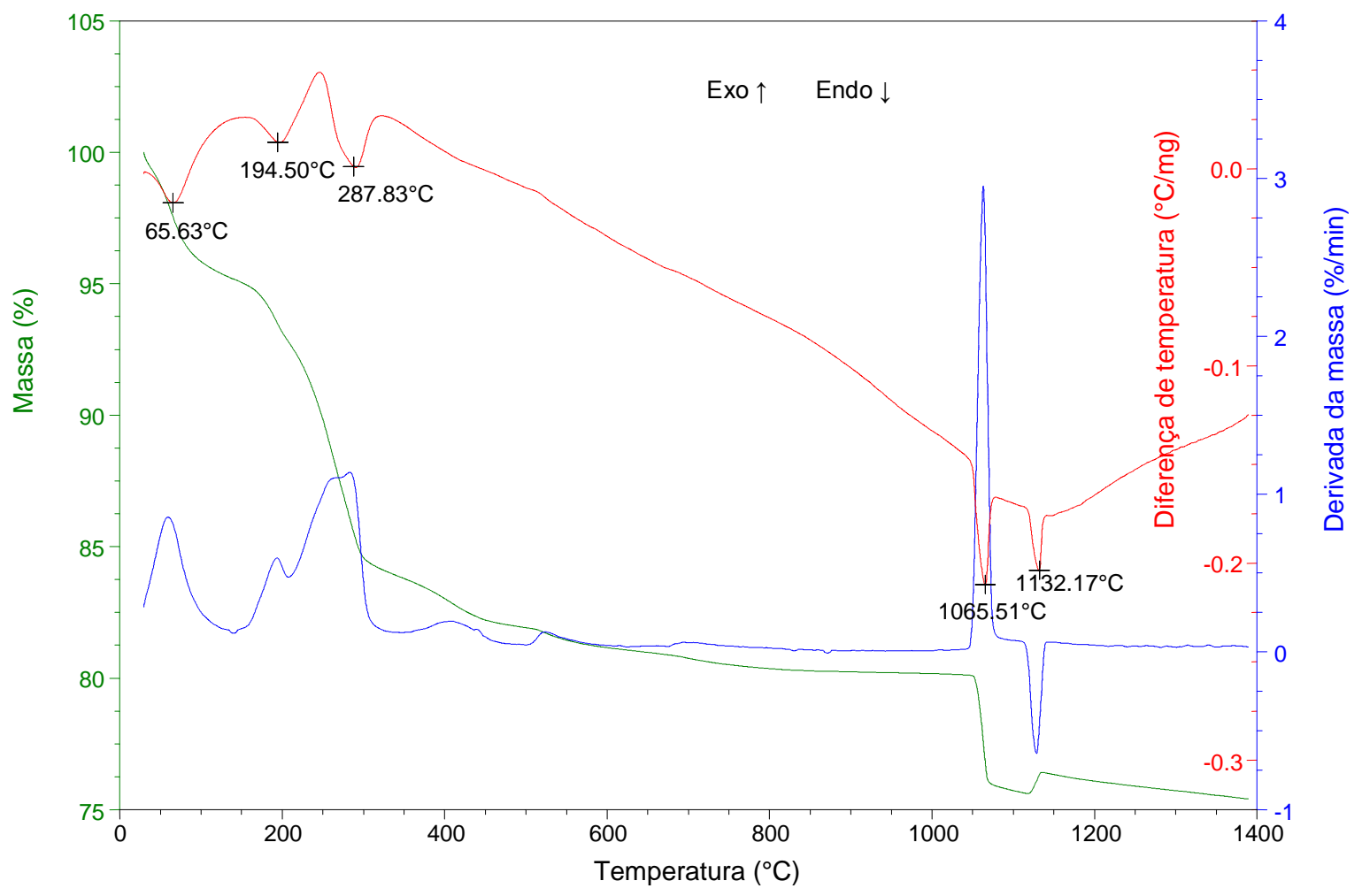

FIGURA 49 - Resultado de ATD/ATG obtido para a amostra RSG 5 (temperatura até $1400^{\circ} \mathrm{C}$, taxa de aquecimento de $10^{\circ} \mathrm{C} / \mathrm{min}$ e atmosfera de ar sintético)
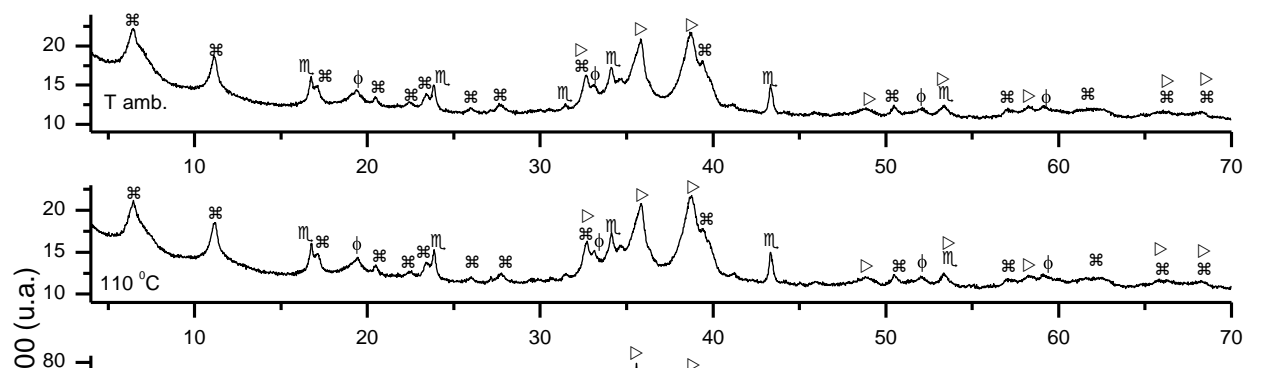

H $\mathrm{Cu}_{36,6} \mathrm{Cl}_{6,7}\left(\mathrm{NO}_{3}\right)_{2,6}(\mathrm{OH})_{63,9}\left(\mathrm{H}_{2} \mathrm{O}\right)_{2,1}$

m. $\mathrm{Cu}(\mathrm{OH})_{2}$

$\phi \mathrm{Ni}(\mathrm{OH})_{2}$

$\begin{array}{ll}\triangleright & \mathrm{CuO} \\ \mathrm{N} & \mathrm{NiO}\end{array}$

$\psi \quad \mathrm{Ni}_{0,75} \mathrm{Cu}_{0,25} \mathrm{O}$

w $\quad \mathrm{Ni}_{0,85} \mathrm{Cu}_{0,15} \mathrm{O}$

(1) $\mathrm{Cu}_{2} \mathrm{O}$
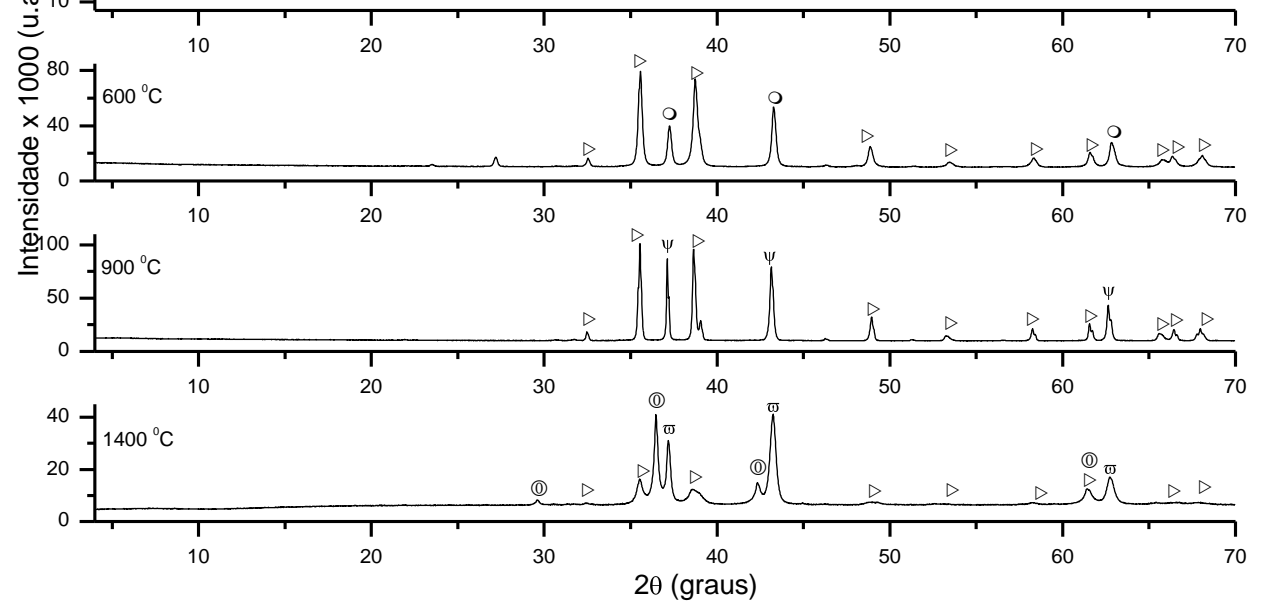

FIGURA 50 - Difratogramas obtidos para a amostra RSG 5, após tratamento em diferentes temperaturas (tubo de cobre) 
TABELA 20 - Resultado dos compostos identificados por DRX na amostra RSG 5, após tratamentos térmicos

\begin{tabular}{|c|c|c|c|c|c|}
\hline \multirow{3}{*}{ Amostra } & \multirow{3}{*}{$\begin{array}{l}\text { Trat. } \\
\text { térmico } \\
\text { (3 h/ar) }\end{array}$} & \multicolumn{4}{|c|}{ Compostos } \\
\hline & & \multirow{2}{*}{ Nome } & \multirow{2}{*}{ Fórmula química } & \multicolumn{2}{|c|}{ Ficha de padrão de difração* } \\
\hline & & & & PDF 2* & Nome $^{*}$ \\
\hline \multirow{15}{*}{ RSG 5} & \multirow{4}{*}{ T amb. } & ** & $\mathrm{Cu}_{36.6} \mathrm{Cl}_{6.7}\left(\mathrm{NO}_{3}\right)_{2.6}(\mathrm{OH})_{63.9}\left(\mathrm{H}_{2} \mathrm{O}\right)_{2.1}$ & 01-071-0677 & Butgembachita \\
\hline & & $\begin{array}{l}\text { Hidróxido de } \\
\text { cobre }\end{array}$ & $\mathrm{Cu}(\mathrm{OH})_{2}$ & 01-072-0140 & $\begin{array}{c}\text { Hidróxido de } \\
\text { cobre }\end{array}$ \\
\hline & & $\begin{array}{c}\text { Hidróxido de } \\
\text { níquel }\end{array}$ & $\mathrm{Ni}(\mathrm{OH})_{2}$ & 00-014-0117 & Teofrastita, sin \\
\hline & & Óxido de cobre & $\mathrm{CuO}$ & 01-089-5896 & Óxido de cobre \\
\hline & \multirow{4}{*}{$110^{\circ} \mathrm{C}$} & $\overline{~ * \star}$ & $\mathrm{Cu}_{36.6} \mathrm{Cl}_{6.7}\left(\mathrm{NO}_{3}\right)_{2.6}(\mathrm{OH})_{63.9}\left(\mathrm{H}_{2} \mathrm{O}\right)_{2.1}$ & 01-071-0677 & Butgembachita \\
\hline & & $\begin{array}{c}\text { Hidróxido de } \\
\text { cobre }\end{array}$ & $\mathrm{Cu}(\mathrm{OH})_{2}$ & 01-072-0140 & $\begin{array}{c}\text { Hidróxido de } \\
\text { cobre }\end{array}$ \\
\hline & & $\begin{array}{c}\text { Hidróxido de } \\
\text { níquel }\end{array}$ & $\mathrm{Ni}(\mathrm{OH})_{2}$ & 00-014-0117 & Teofrastita, sin \\
\hline & & Óxido de cobre & $\mathrm{CuO}$ & 01-089-5896 & Óxido de cobre \\
\hline & \multirow{2}{*}{$600^{\circ} \mathrm{C}$} & Óxido de cobre & $\mathrm{CuO}$ & 01-089-5895 & Óxido de cobre \\
\hline & & Óxido de níquel & $\mathrm{NiO}$ & 00-044-1159 & Óxido de níquel \\
\hline & \multirow[b]{2}{*}{$900^{\circ} \mathrm{C}$} & Óxido de cobre & $\mathrm{CuO}$ & 00-080-0076 & Tenorita, sin \\
\hline & & $\begin{array}{c}\text { Óxido de cobre } \\
\text { e níquel }\end{array}$ & $\mathrm{Ni}_{0,75} \mathrm{Cu}_{0,25} \mathrm{O}$ & 01-078-0648 & $\begin{array}{c}\text { Óxido de cobre } \\
\text { e níquel }\end{array}$ \\
\hline & \multirow{3}{*}{$1400^{\circ} \mathrm{C}$} & Óxido de cobre & $\mathrm{CuO}$ & 00-080-0076 & Tenorita, sin \\
\hline & & Óxido de cobre I & $\mathrm{Cu}_{2} \mathrm{O}$ & 01-078-2076 & Cuprita \\
\hline & & $\begin{array}{c}\begin{array}{c}\text { Oxido de cobre } \\
\text { e níquel }\end{array} \\
\end{array}$ & $\mathrm{Ni}_{0,85} \mathrm{Cu}_{0,15} \mathrm{O}$ & 01-078-0646 & $\begin{array}{c}\text { Óxido de cobre } \\
\text { e níquel }\end{array}$ \\
\hline
\end{tabular}

As observações microestruturais da amostra de RSG 5, na forma de pó, como recebida e após tratamentos térmicos a $110^{\circ} \mathrm{C}, 600^{\circ} \mathrm{C}, 900^{\circ} \mathrm{C}$ e $1400^{\circ} \mathrm{C}$ estão expressas nas micrografias das FIG. 51, 52, 53 e 54.

Observa-se que entre a amostra como recebida ( $T$ amb.) e a amostra seca $\left(110^{\circ} \mathrm{C}\right)$ praticamente não há diferença na morfologia. Ambas apresentam aglomerados constituídos por partículas finas. A partir de $600^{\circ} \mathrm{C}$, observa-se a formação de fases diferenciadas. A análise por EDS realizada em três morfologias distintas observadas na estrutura, na amostra tratada a $900^{\circ} \mathrm{C}$ (FIG. 53), mostra que o composto 1 é provavelmente constituído por óxido de cobre $(\mathrm{CuO})$ e os compostos 2 e 3 são provavelmente constituídos pelos óxidos de cobre e níquel identificados por DRX nas mesmas amostras. 


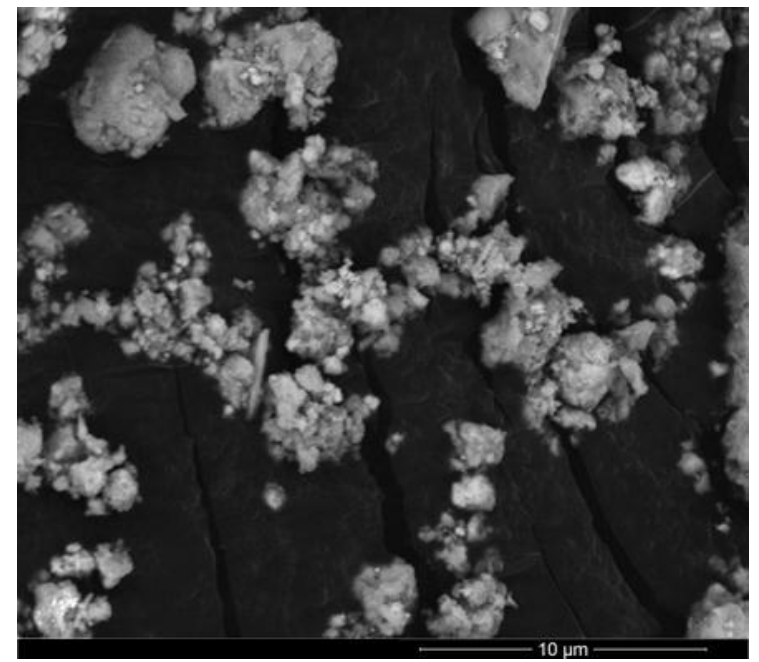

a)

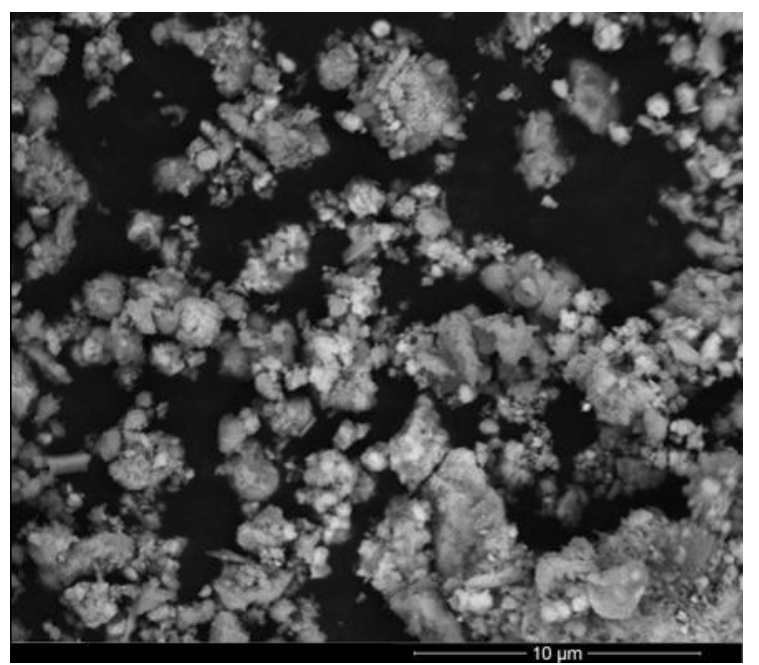

b)

FIGURA 51 - Micrografias obtidas para a amostra RSG 5 tratada a: a) T amb. e b) $110^{\circ} \mathrm{C}$

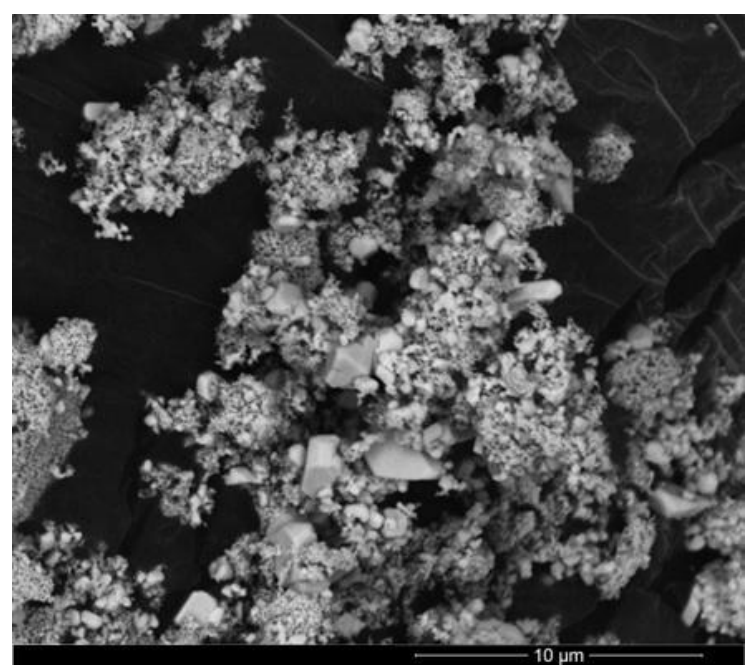

FIGURA 52 - Micrografia obtida para a amostra RSG 5 tratada a $600^{\circ} \mathrm{C}$

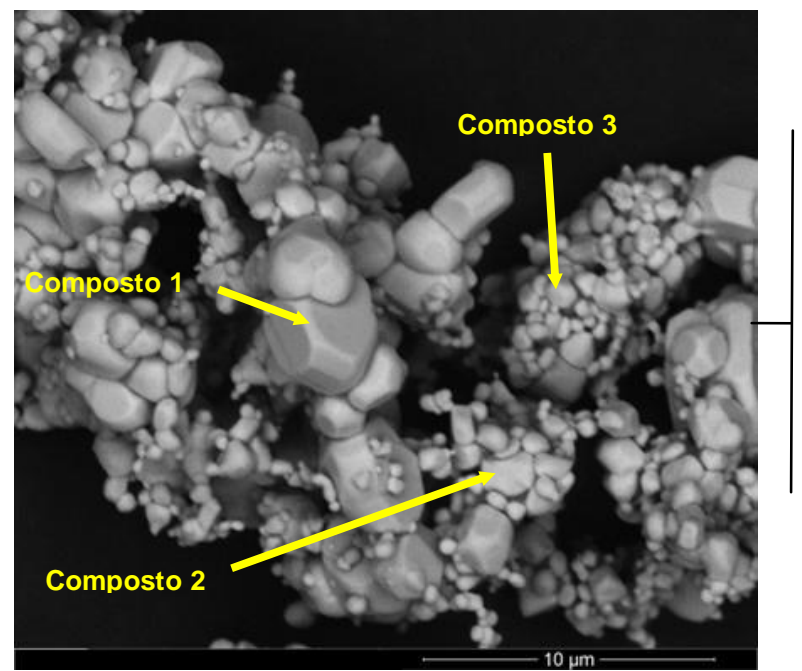

EDS:

$\begin{array}{ccc}\text { Composto 1 } & \text { Composto 2 } & \text { Composto 3 } \\ \mathrm{Cu}(66 \%) & \mathrm{Ni}(66 \%) & \mathrm{O}(38 \%) \\ \mathrm{O}(21 \%) & \mathrm{Cu}(25 \%) & \mathrm{Ni}(37 \%) \\ \mathrm{C}(13 \%) & \mathrm{O}(9 \%) & \mathrm{Cu}(15 \%) \\ & & \mathrm{C}(10 \%)\end{array}$

FIGURA 53 - Micrografia obtida para a amostra RSG 5 tratada a $900^{\circ} \mathrm{C}$ e microanálise química dos compostos 1,2 e 3 


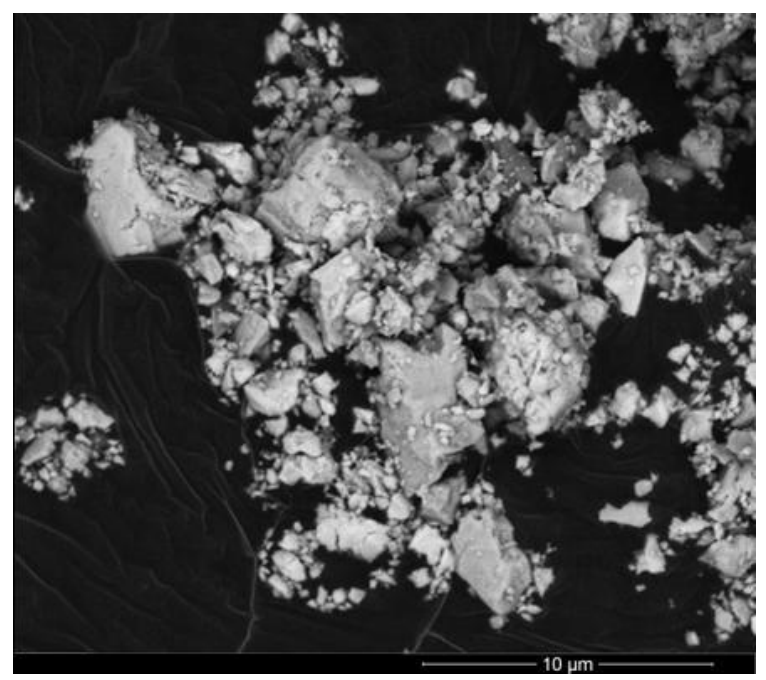

FIGURA 54 - Micrografia obtida para a amostra RSG 5 tratada a $1400^{\circ} \mathrm{C}$

\subsubsection{Obtenção de materiais vítreos com incorporação dos resíduos sólidos} galvânicos

Visando utilizar os resíduos sólidos como materiais funcionais em produtos manufaturados capazes de inertizar as substâncias consideradas perigosas, ensaios foram realizados para a incorporação dos RSGs em materiais vítreos.

De acordo com suas características químicas e físico-químicas, as amostras de RSG 2, RSG 5 e RSG 4 foram selecionadas como potenciais para a elaboração das matrizes vítreas. $O$ detalhamento das principais razões para a utilização destes RSGs está apresentado na TAB. 21.

TABELA 21 - Principais razões para a utilização dos RSGs na composição vítrea

\begin{tabular}{|c|c|c|c|}
\hline Resíduo & Justificativa & Observações & $\begin{array}{l}\text { Concentração na } \\
\text { composição }\end{array}$ \\
\hline \multirow{2}{*}{ RSG 2} & \multirow{2}{*}{$\begin{array}{l}\text { Apresenta teores médios } \\
\text { de cromo e dos principais } \\
\text { elementos químicos }\end{array}$} & \multirow{4}{*}{$\begin{array}{l}\text { A presença de metais alcalinos e } \\
\text { de transição nos RSGs pode } \\
\text { gerar vidros coloridos, de } \\
\text { interesse para a indústria, assim } \\
\text { como fritas para a confecção de } \\
\text { pigmentos e esmaltes } \\
\text { cerâmicos. A presença do } \\
\text { elevado teor de cobre no RSG } 5 \\
\text { pode proporcionar uma cor } \\
\text { específica e, dependendo da } \\
\text { formulação, proporcionar } \\
\text { aspectos metálicos }\end{array}$} & $\begin{array}{l}27 \% \text { de RSG } 2 \text { para } \\
\text { confecção de frita }\end{array}$ \\
\hline & & & $\begin{array}{l}20 \% \text { de RSG } 2 \text { para } \\
\text { confecção de vidro }\end{array}$ \\
\hline RSG 5 & $\begin{array}{l}\text { Apresenta baixo teor de } \\
\text { cromo e elevado teor de } \\
\text { cobre }\end{array}$ & & $\begin{array}{l}\text { 24\% de RSG } 5 \text { para } \\
\text { confecção de frita }\end{array}$ \\
\hline RSG 4 & $\begin{array}{l}\text { Apresenta teor } \\
\text { intermediário de cromo em } \\
\text { relação às duas anteriores } \\
\text { e teores médios dos } \\
\text { demais elementos }\end{array}$ & & $\begin{array}{l}21 \% \text { de RSG } 4 \text { para } \\
\text { confecção de vidro }\end{array}$ \\
\hline
\end{tabular}


Tendo como base as composições calculadas, apresentadas nos itens 4.2.4.1 e 4.2.4.2, as misturas foram fundidas nas condições mencionadas no item 4.2.4.3 para a obtenção dos produtos denominados como F $27 \mathbf{R} 229 \mathbf{N} 6 \mathbf{C}$, V 20R2 29N 11C, F 24R5 27N 0,5C e V 21R4 21N 5C.

As duas primeiras composições formuladas foram fundidas $\left(1300^{\circ} \mathrm{C} / 2 \mathrm{~h}\right)$ e os líquidos formados apresentaram baixa viscosidade, ideal ao processo de formação de matrizes vítreas, pois não prejudica a etapa de vertimento. A FIG. 55 mostra a retirada do material fundido do forno e seu vertimento em água, originando a frita F $27 \mathbf{R 2} 29$ N 6C (FIG. 56), que apresentou baixa granulação, e é de interesse para a confecção de esmaltes cerâmicos, pois oferece facilidade para cominuição.

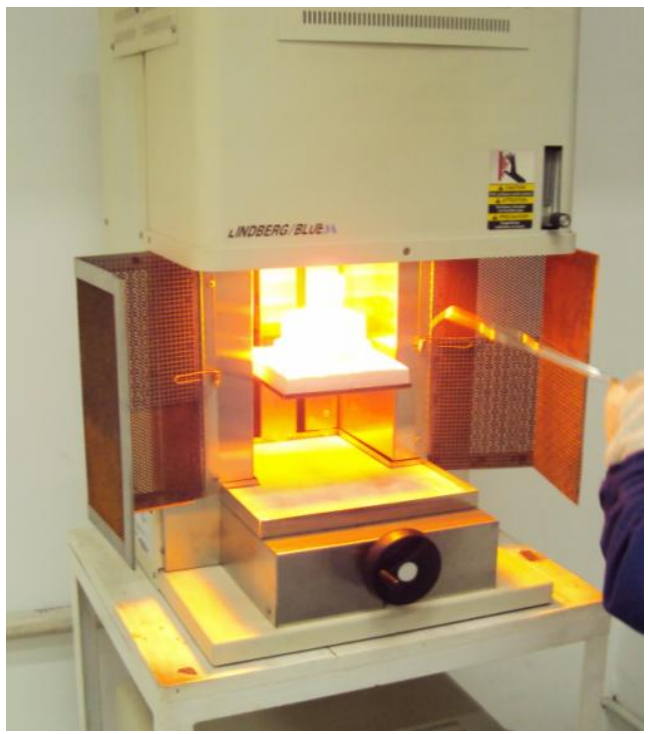

a)

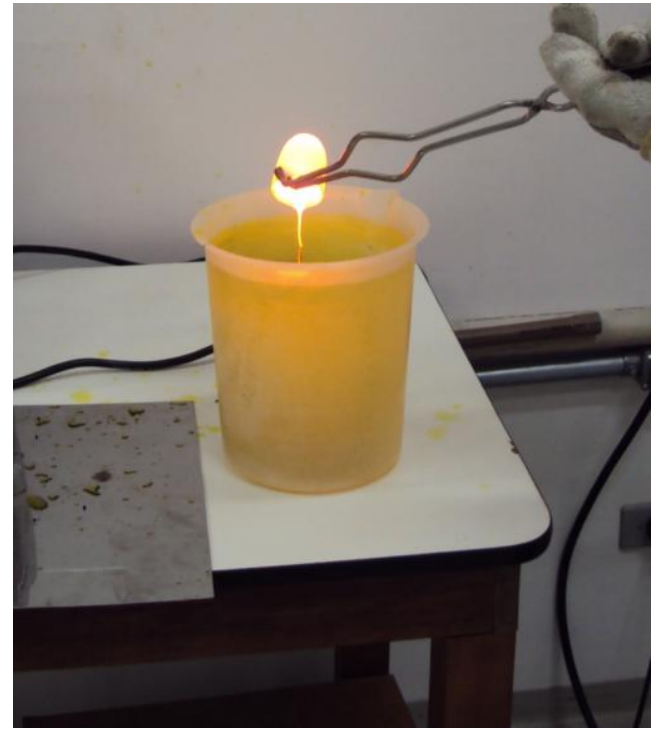

b)

FIGURA 55 - Retirada de material fundido do forno para obtenção de frita com incorporação de RSG 2 (F 27R2 29N 6C): a) Abertura do forno e b) Vertimento em água

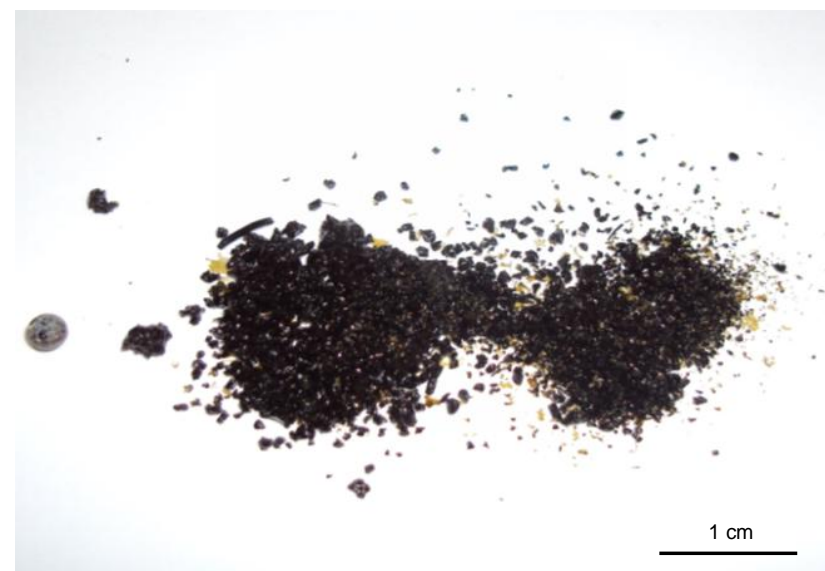

FIGURA 56 - Frita obtida com incorporação de RSG 2 (F $27 R 2$ 29N 6C) 
O vidro vertido no molde prismático (V 20R2 29N 11C) está mostrado na FIG. 57 e aparentemente apresentou propriedades satisfatórias, no entanto, foi observado que o cromo não incorporou completamente em sua estrutura, assim como também ocorreu para a frita, uma vez que a água adquiriu coloração amarela e o vidro apresentou resíduos amarelos aderidos à superfície, que são características da presença de cromo hexavalente.

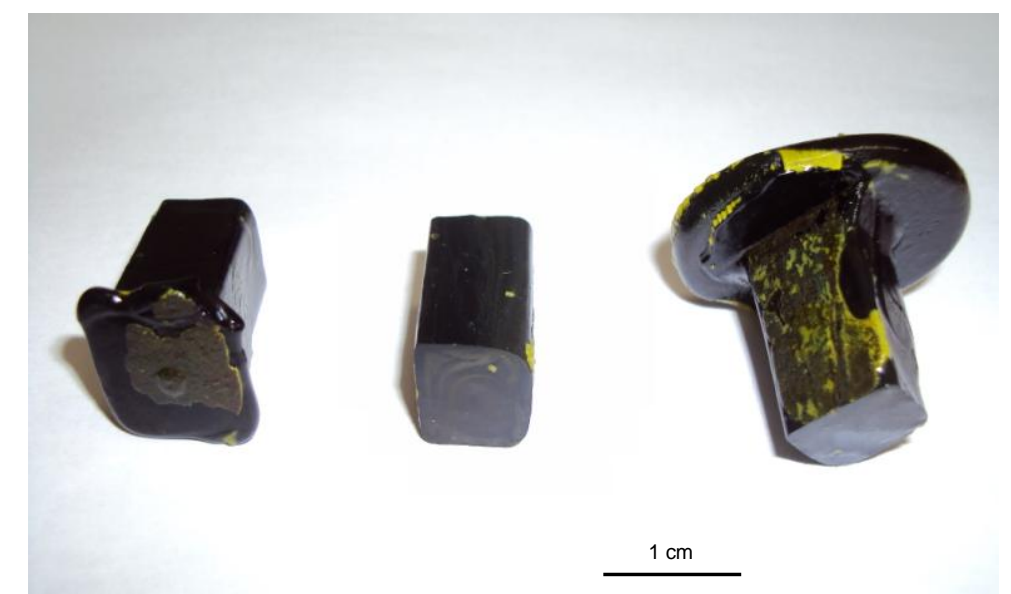

FIGURA 57 - Vidro obtido com incorporação de RSG 2 (V 20R2 29N 11C)

O líquido amarelo foi analisado por FRX e os resultados obtidos comprovaram a presença de cromo como preponderante (38\%), seguido de sódio (24\%) e enxofre (22\%). O teor de silício foi detectado em pequena proporção (5\%) e os teores de $\mathrm{K}, \mathrm{Ca}, \mathrm{Cl}, \mathrm{Al}, \mathrm{Mg}, \mathrm{Fe}, \mathrm{Ni}, \mathrm{Cu}$ e $\mathrm{P}$ foram detectados na forma de traços $(0,1 \%$ a $2 \%)$. Na TAB. 22 , estes resultados estão apresentados, sugerindo que, exceto o cromo, os demais metais incorporaram à estrutura vítrea.

TABELA 22 - Resultado dos elementos detectados no líquido recolhido durante a obtenção de frita com incorporação de RSG 2, por FRX

\begin{tabular}{c|c|c}
\hline Amostra & Ordem de preponderância & Elementos detectados \\
\hline \multirow{2}{*}{$\begin{array}{c}\text { Líquido recolhido durante a } \\
\text { obtenção de frita com } \\
\text { incorporação de RSG 2 }\end{array}$} & Preponderantes & $\mathrm{Cr}, \mathrm{Na}$ e S \\
\cline { 2 - 3 } & Pequenas proporções & $\mathrm{Si}$ \\
\cline { 2 - 3 } & Traços & $\mathrm{K}, \mathrm{Ca}, \mathrm{Cl}, \mathrm{Al}, \mathrm{Mg}, \mathrm{Fe}, \mathrm{Ni}, \mathrm{Cu}$ e P \\
\hline
\end{tabular}

A incorporação dos metais de transição, como níquel e cobre, à estrutura do vidro é um resultado importante, uma vez que são metais pesados e estão presentes em grandes quantidades nos RSGs. No entanto, não se pode ter 
uma indústria de fabricação de vidro para inertização de lodo galvânico, cujo cromo não participe da estrutura vítrea.

A formulação contendo RSG 5 é particularmente interessante pelo fato deste resíduo apresentar, quando comparado aos demais, alto teor de cobre e baixo teor de cromo, podendo ter alto apelo funcional, a fim de favorecer a trabalhabilidade dos vidros. À composição, adicionou-se $\mathrm{B}_{2} \mathrm{O}_{3}$, acompanhando os bons resultados obtidos na literatura ${ }^{74,75}$, uma vez que este composto pode promover a diminuição da temperatura de trabalho, facilitar o refino, aumentar a estabilidade química e melhorar a resistência do vidro ao ataque químico.

Após a fusão $\left(1300^{\circ} \mathrm{C} / 2 \mathrm{~h}\right)$, o líquido formado apresentou média viscosidade, com boas condições para o vertimento. A frita e o líquido são apresentados na FIG. 58.

A frita (F 24R5 27N 0,5C) apresentou boas características de cor e estabilidade, visando a confecção de, por exemplo, esmaltes cerâmicos, e o líquido não apresentou coloração amarela, como pode ser observado na FIG. 58. A presença de cromo no líquido foi verificada com adição de difenilcarbazida. A FIG. 59 apresenta os resultados obtidos, após a adição deste reagente em uma solução padrão contendo cromo e na amostra analisada, para fins comparativos. Observa-se que a amostra não continha cromo, pois somente adquiriu coloração rosada a solução padrão da esquerda. A amostra analisada, à direita, manteve-se incolor.

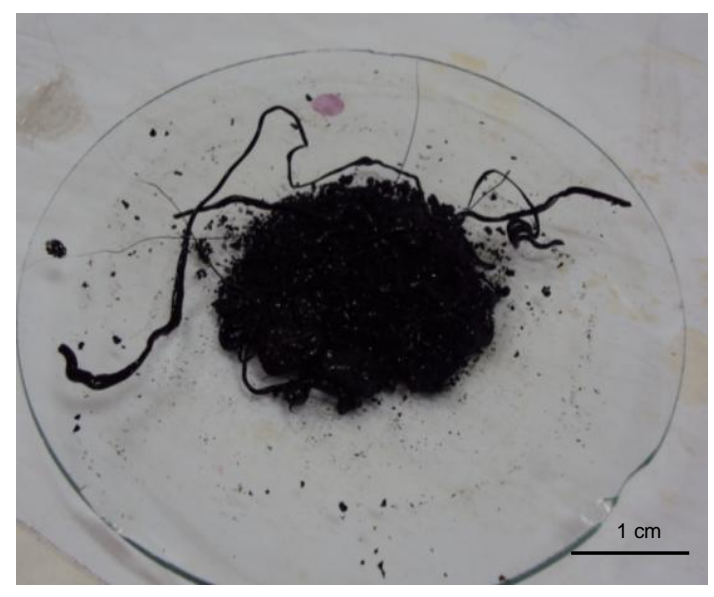

a)

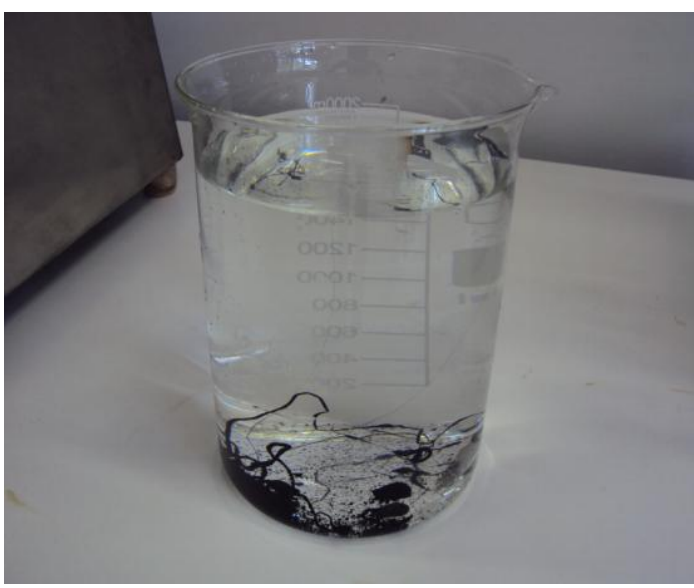

b)

FIGURA 58 - Formação de frita com incorporação de RSG 5: a) Frita obtida (F 24R5 27N 0,5C) e b) Líquido incolor recolhido após vertimento 


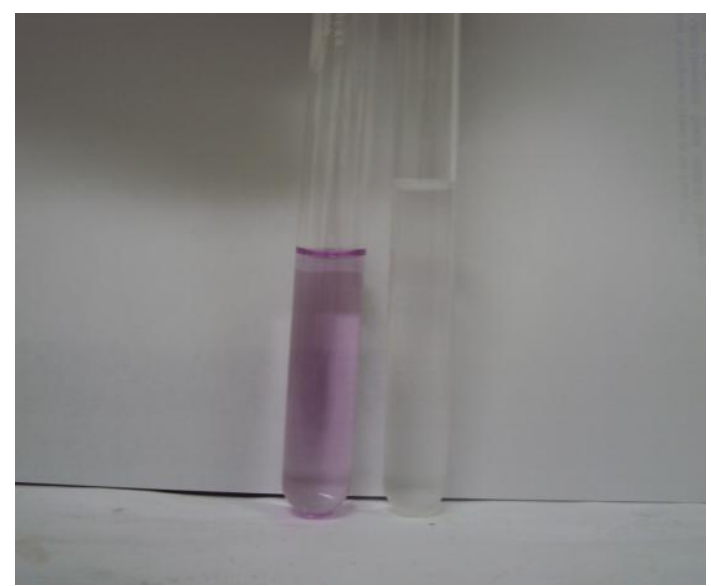

FIGURA 59 - Ensaio qualitativo para verificar presença de cromo. À esquerda: tubo de ensaio com solução padrão contendo cromo e à direita: tubo de ensaio com a amostra

Para comprovar a ausência de cromo no líquido e verificar se os demais elementos foram incorporados à estrutura vítrea, análise foi realizada por ICP-AES. Os resultados obtidos foram plenamente satisfatórios, com a confirmação da ausência de cromo e de demais elementos funcionais, indicando suas incorporações na rede vítrea, conforme TAB. 23.

TABELA 23 - Resultado dos elementos detectados no líquido recolhido durante a obtenção de frita com incorporação de RSG 5, por ICP-AES

\begin{tabular}{|c|c|c|c|c|}
\hline Amostra & Elemento & Teor & Elemento & Teor \\
\hline \multirow{14}{*}{$\begin{array}{l}\text { Líquido recolhido } \\
\text { durante a obtenção } \\
\text { de frita com } \\
\text { incorporação de } \\
\text { RSG } 5\end{array}$} & $\mathrm{Ag}$ & $0,0034 \pm 0,0007$ & $\mathrm{Mn}$ & - \\
\hline & $\mathrm{Al}$ & $0,0189 \pm 0,0036$ & $\mathrm{Na}$ & $1,6900 \pm 0,0643$ \\
\hline & $\mathrm{Au}$ & - & $\mathrm{Ni}$ & - \\
\hline & B & * & $\mathrm{P}$ & $0,2730 \pm 0,1025$ \\
\hline & $\mathrm{Ba}$ & $0,0029 \pm 0,0006$ & $\mathrm{~Pb}$ & - \\
\hline & $\mathrm{Ca}$ & $4,6842 \pm 0,2099$ & $\mathrm{Pd}$ & - \\
\hline & $\mathrm{Cd}$ & - & $\mathrm{Pt}$ & $0,0068 \pm 0,0002$ \\
\hline & $\mathrm{Cl}^{-}$ & * & $S$ & * \\
\hline & Co & - & $\mathrm{Si}$ & $3,9310 \pm 0,1889$ \\
\hline & $\mathrm{Cr}$ & - & Sn & - \\
\hline & $\mathrm{Cu}$ & $0,0296 \pm 0,0109$ & $\mathrm{Sr}$ & $0,0409 \pm 0,0011$ \\
\hline & $\mathrm{Fe}$ & $0,0300 \pm 0,0227$ & $\mathrm{Ti}$ & - \\
\hline & $\mathrm{K}$ & $2,0035 \pm 0,3919$ & $\mathrm{Zn}$ & $0,0382 \pm 0,0151$ \\
\hline & $\mathrm{Mg}$ & $0,7506 \pm 0,0497$ & $\mathrm{Zr}$ & - \\
\hline
\end{tabular}


A presença de $\mathrm{Ca}, \mathrm{Na}, \mathrm{K}$ e Si, em maiores teores no líquido analisado, sugere que partes destes elementos podem ter sido substituídos para a fixação dos metais presentes no RSG, pois, por teoria, estes elementos também podem atuar como modificadores de rede ${ }^{72}$.

A formulação contendo RSG 4 foi fundida alterando-se as condições de operação $\left(1500^{\circ} \mathrm{C} / 3 \mathrm{~h}\right)$. No diagrama de fases, esta composição se aproxima das dos vidros comerciais, conforme anteriormente verificado na FIG. 8. Após a fusão, o líquido apresentou elevada viscosidade e foi observada dificuldade para o vertimento, mesmo a $1500^{\circ} \mathrm{C}$, por $3 \mathrm{~h}$, como mostra a FIG. 60 .

No vidro obtido (V 21R4 21N5C), apresentado na FIG.61, não se formou película superficial, nem houve desprendimento de nenhuma substância, mesmo após vários dias, indicando boa estabilidade em presença de umidade do ar e durante o manuseio, com provável incorporação de cromo.

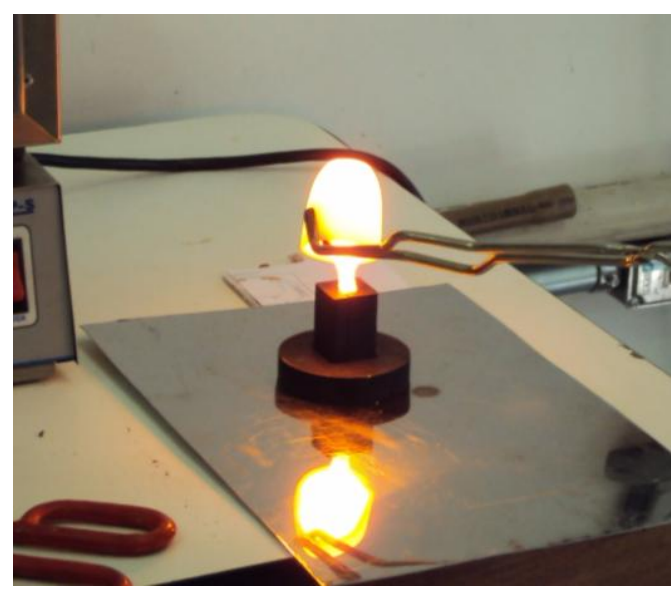

a)

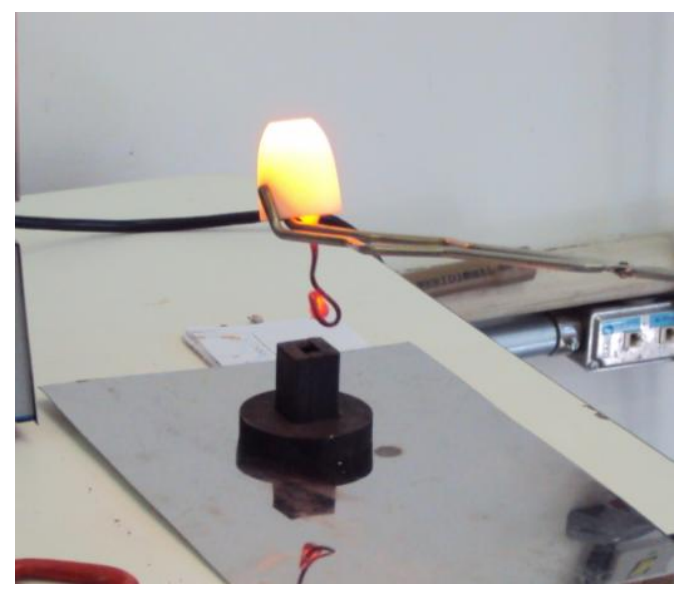

b)

FIGURA 60 - Obtenção de vidro com incorporação de RSG 4: a) Início de vertimento do material fundido em molde de aço pré aquecido a $500^{\circ} \mathrm{C}$ e b) Solidificação do vidro devido à alta viscosidade

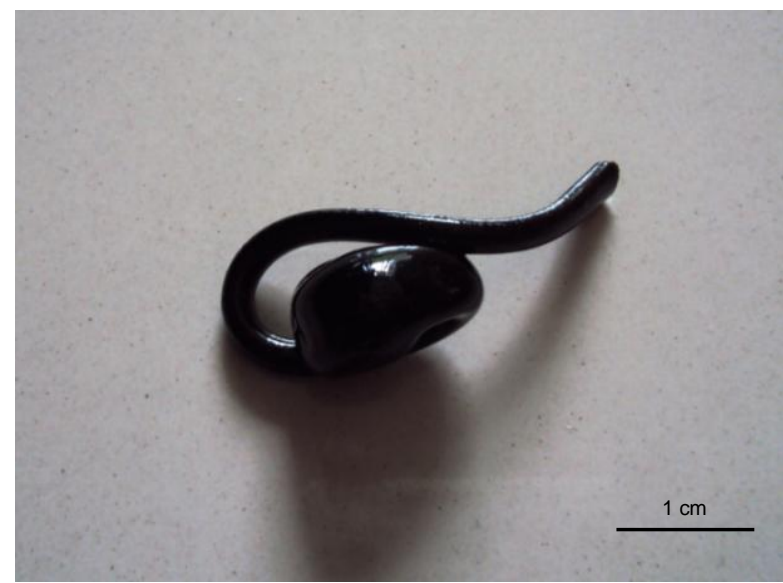


Na FIG. 62, estão apresentados os registros fotográficos retirados com luz artificial da câmera fotográfica (flash). As duas primeiras imagens mostram, respectivamente, a frita obtida com incorporação de RSG 2 e o vidro obtido com incorporação de RSG 4, ambos de coloração azulada. As duas últimas imagens mostram, respectivamente, o vidro obtido com incorporação de RSG 2 e a frita obtida com incorporação de RSG 5, ambos de coloração preta. A coloração azul pode ser proveniente do cobre ou do níquel e a coloração preta pode ser proveniente do cobre ${ }^{74}$. Tal propriedade é interessante comercialmente, pois alguns segmentos utilizam vidros coloridos.

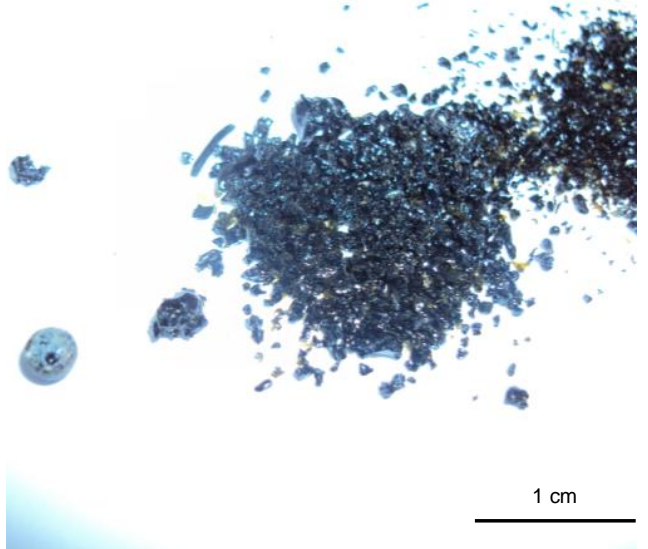

a)

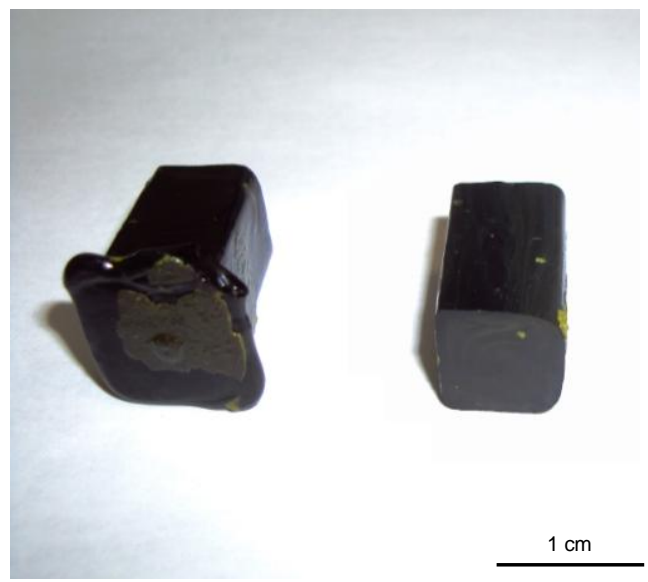

c)

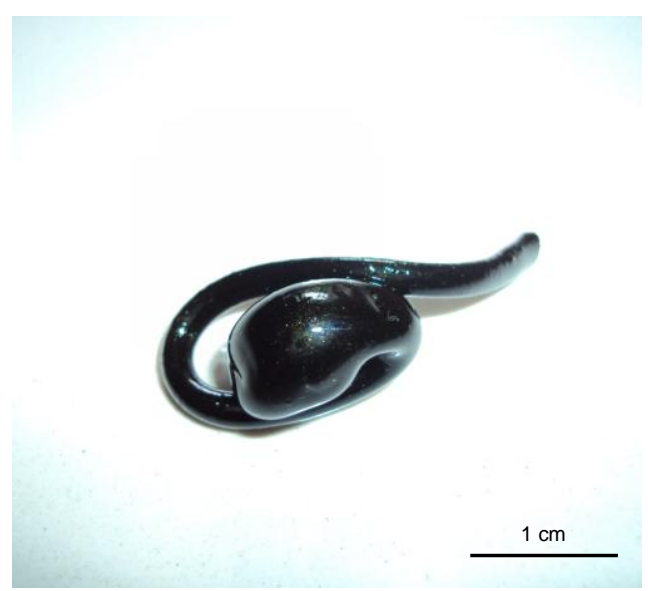

b)

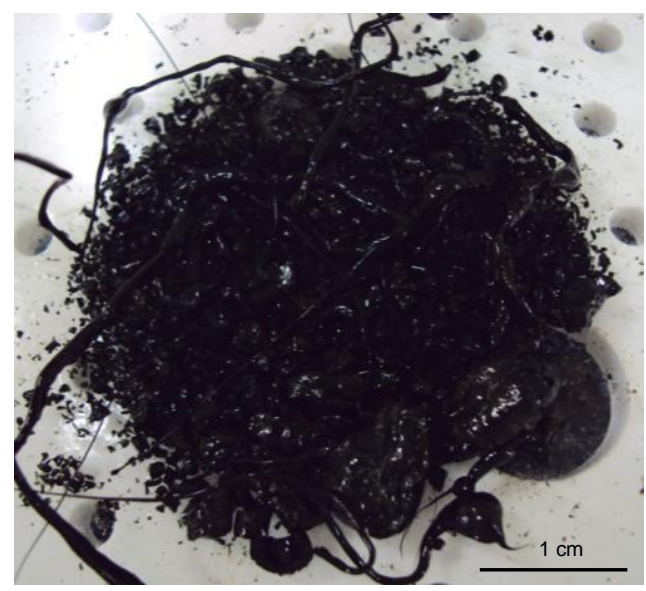

d)

FIGURA 62 - Obtenção de produtos vítreos coloridos: a) Frita azulada (F 27R2 29N 6C); b) Vidro azulado (V 21R4 21N 5C); c) Vidro preto (V 20R2 29N 11C) e d) Frita preta (F $24 \mathbf{R} 527 \mathbf{N} 0,5 \mathbf{C})$ 
A porcentagem de cada óxido presente nos produtos finais foi obtida por análises químicas para comparar com a porcentagem dos óxidos presentes nas misturas de partida. Os resultados estão apresentados na TAB. 24, para as fritas obtidas com incorporação de RSG 2 e RSG 5 e para o vidro obtido com incorporação de RSG 4. O vidro obtido com incorporação de RSG 2 não foi analisado.

Analisando-se os resultados obtidos, observa-se que houve variações de composição. A alumina sempre tem seu teor aumentado, devido ao cadinho utilizado ser de alumina. Durante a fusão, o líquido interage com as paredes do cadinho, dissolvendo a alumina, que passa a fazer parte da composição do produto final.

Para a frita com RSG 2 (F 27R2 29N 6C), observa-se que vários óxidos metálicos tiveram seus teores aumentados no produto final, como para o $\mathrm{CuO}$, $\mathrm{Fe}_{2} \mathrm{O}_{3}, \mathrm{MgO}, \mathrm{Na}_{2} \mathrm{O}, \mathrm{NiO}, \mathrm{PbO}, \mathrm{SrO}$ e $\mathrm{ZnO}$. Isto se deve à quantidade de compostos não detectados $\left(\mathrm{P}_{2} \mathrm{O}_{5}\right)$ ou mesmo não analisados $(\mathrm{Ag}, \mathrm{Au}, \mathrm{BaO}, \mathrm{CdO}$, $\mathrm{Cl}, \mathrm{CoO}, \mathrm{Pd}, \mathrm{Pt}, \mathrm{SO}_{3}, \mathrm{Sn}$ e $\mathrm{Y}$ ), que causaram o aumento da proporcionalidade destes no produto final. Possivelmente a redução do teor de $\mathrm{CaO}$ é a responsável pela entrada dos metais de transição na estrutura. Observa-se, também, a diminuição do teor de $\mathrm{Cr}_{2} \mathrm{O}_{3}$, indicando que este não foi incorporado adequadamente à estrutura. A diferença entre o teor de $\mathrm{Cr}_{2} \mathrm{O}_{3}$ na mistura de partida e no produto final é de 1,9\% em massa, podendo ser maior, devido ao aumento de proporcionalidade no produto final.

Para a frita com RSG 5 (F $24 R 5$ 27N 0,5C), observa-se a incorporação de $\mathrm{CdO}, \mathrm{K}_{2} \mathrm{O}, \mathrm{MgO}, \mathrm{MnO}, \mathrm{PbO}, \mathrm{Pd}$ e $\mathrm{ZnO}$ e de grande parte de $\mathrm{CuO}$ e $\mathrm{NiO}$, além de parte de $\mathrm{Fe}_{2} \mathrm{O}_{3}$. Neste caso, o $\mathrm{CaO}$ e $0 \mathrm{Na}_{2} \mathrm{O}$ provavelmente deram lugar à entrada dos metais na estrutura vítrea. $\mathrm{O}_{\mathrm{Cr}_{2} \mathrm{O}_{3}}$ teve seu teor reduzido, mas o ensaio qualitativo na água utilizada durante o vertimento mostrou não haver presença de cromo. O teor é baixo para determinar se esta pequena quantidade foi incorporada à estrutura ou ficou dissolvida no líquido.

Para o vidro com RSG 4 (V 21 R4 21 N 5C), observa-se a incorporação de $\mathrm{BaO}, \mathrm{Cr}_{2} \mathrm{O}_{3}, \mathrm{CuO}, \mathrm{Fe}_{2} \mathrm{O}_{3}, \mathrm{~K}_{2} \mathrm{O}, \mathrm{MgO}, \mathrm{MnO}, \mathrm{P}_{2} \mathrm{O}_{5}, \mathrm{PbO}, \mathrm{Sn}$, Sr e $\mathrm{ZnO}$ e de grande parte de $\mathrm{NiO}$. Os teores de $\mathrm{CaO}$ e $\mathrm{Na}_{2} \mathrm{O}$ indicam que, provavelmente, estes compostos também foram os responsáveis pela entrada dos metais na estrutura vítrea. Observa-se que $\mathrm{O}_{\mathrm{Cr}_{2} \mathrm{O}_{3}}$ foi praticamente todo incorporado, 
considerando as possíveis variações de composição entre o produto não formado e após formado.

TABELA 24 - Comparação dos teores dos óxidos antes e após a obtenção dos materiais vítreos

\begin{tabular}{|c|c|c|c|c|c|c|}
\hline \multirow{3}{*}{ Composto } & \multicolumn{6}{|c|}{$\%$ em massa } \\
\hline & \multicolumn{2}{|c|}{ Frita com RSG 2} & \multicolumn{2}{|c|}{ Frita com RSG 5} & \multicolumn{2}{|c|}{ Vidro com RSG 4} \\
\hline & $\begin{array}{c}\text { Partida } \\
\text { (calculado) }\end{array}$ & $\begin{array}{l}\text { Analisado } \\
\text { (ICP-AES) }\end{array}$ & $\begin{array}{c}\text { Partida } \\
\text { (calculado) }\end{array}$ & $\begin{array}{l}\text { Analisado } \\
\text { (ICP-AES) }\end{array}$ & $\begin{array}{c}\text { Partida } \\
\text { (calculado) }\end{array}$ & $\begin{array}{l}\text { Analisado } \\
\text { (ICP-AES) }\end{array}$ \\
\hline $\mathrm{Ag}$ & 0,00001 & * & - & 0,0002 & - & 0,0046 \\
\hline $\mathrm{Al}_{2} \mathrm{O}_{3}$ & 1,75484 & 4,0253 & 1,60871 & 13,2790 & 1,94931 & 5,2147 \\
\hline $\mathrm{Au}$ & - & * & - & * & - & * \\
\hline $\mathrm{B}_{2} \mathrm{O}_{3}$ & 9,68364 & 0,2877 & 11,50748 & 13,3246 & 0,45598 & 0,0377 \\
\hline $\mathrm{BaO}$ & 0,00951 & * & - & 0,0010 & 0,03353 & 0,0382 \\
\hline $\mathrm{CaO}$ & 6,01724 & 3,6782 & 0,47619 & 0,0804 & 5,07304 & 4,5591 \\
\hline $\mathrm{CdO}$ & 0,00003 & * & 0,00066 & 0,0004 & - & 0,0028 \\
\hline $\mathrm{Cl}$ & 0,08848 & * & 0,75824 & * & 0,09411 & * \\
\hline $\mathrm{CoO}$ & 0,00021 & * & - & 0,0018 & - & 0,0007 \\
\hline $\mathrm{Cr}_{2} \mathrm{O}_{3}$ & 7,42556 & 5,5088 & 0,32618 & 0,0206 & 5,45409 & 4,6599 \\
\hline $\mathrm{CuO}$ & 0,29804 & 0,7517 & 13,43049 & 9,8091 & 0,16157 & 0,1188 \\
\hline $\mathrm{Fe}_{2} \mathrm{O}_{3}$ & 1,52783 & 2,8489 & 1,10410 & 0,2928 & 1,09431 & 1,3410 \\
\hline $\mathrm{K}_{2} \mathrm{O}$ & 0,52136 & 0,0626 & 1,12890 & 1,1634 & 0,11525 & 0,0748 \\
\hline $\mathrm{MgO}$ & 0,24971 & 0,4991 & 0,04337 & 0,0392 & 0,08673 & 0,1355 \\
\hline $\mathrm{MnO}$ & 0,01804 & 0,0222 & 0,01291 & 0,0084 & 0,00205 & 0,0052 \\
\hline $\mathrm{Na}_{2} \mathrm{O}$ & 28,80433 & 36,8677 & 26,75964 & 20,8087 & 21,40286 & 16,3241 \\
\hline $\mathrm{NiO}$ & 4,34688 & 7,0326 & 6,40328 & 4,7230 & 4,98599 & 2,3263 \\
\hline $\mathrm{P}_{2} \mathrm{O}_{5}$ & 0,02321 & - & 0,52312 & 1,6402 & 0,03917 & 0,0217 \\
\hline $\mathrm{PbO}$ & 0,00774 & 0,0182 & 0,00094 & 0,0004 & 0,02549 & 0,0059 \\
\hline $\mathrm{Pd}$ & - & * & 0,00058 & 0,0024 & - & 0,0011 \\
\hline $\mathrm{Pt}$ & 0,00007 & * & 0,02383 & 0,0020 & 0,01352 & 0,0004 \\
\hline $\mathrm{SO}_{3}$ & 1,02027 & * & 0,30648 & * & 2,83598 & * \\
\hline $\mathrm{SiO}_{2}$ & 37,70050 & 37,7765 & 35,30839 & 34,5209 & 55,98132 & 65,0414 \\
\hline Sn & 0,00084 & * & - & 0,0036 & 0,00239 & 0,0581 \\
\hline $\mathrm{SrO}$ & 0,00096 & 0,0091 & - & 0,0006 & 0,00400 & 0,0074 \\
\hline $\mathrm{TiO}_{2}$ & - & 0,0167 & - & 0,0144 & - & - \\
\hline$Y$ & 0,00059 & * & - & * & - & 0,0010 \\
\hline $\mathrm{ZnO}$ & 0,40063 & 0,5924 & 0,18193 & 0,1706 & 0,01931 & 0,0198 \\
\hline $\mathrm{Zr}$ & - & 0,0023 & - & 0,0923 & - & - \\
\hline
\end{tabular}


Estes resultados mostraram que é possível incorporar os resíduos sólidos de galvanoplastia numa estrutura vítrea, obtendo-se produtos de utilidade comercial, como vidros coloridos e fritas cerâmicas. As fritas também podem ser utilizadas posteriormente em esmaltes cerâmicos, por exemplo, que geralmente necessitam de partículas reduzidas. Trabalhos na literatura ${ }^{30,38,39,40,74,75}$ demonstram a boa resistência química e físico-química de vidros soda-cal obtidos com incorporação de resíduos sólidos de galvanoplastia, indicando que é possível inertizar os elementos tóxicos dos RSGs em matrizes vítreas, mantendo tais estruturas estáveis, sem contaminar o ambiente. As adições de RSGs neste trabalho foram da ordem de $20 \%$ a $30 \%$ em massa, mas outras proporções podem ser adotadas para alterar as propriedades do vidro.

O custo da incorporação em vidros foi estimado com base apenas no custo dos reagentes utilizados, considerando a doação dos RSGs por parte das empresas, e sem considerar os custos com mão de obra, energia, água e o lucro, além de outros, certamente somados em escala industrial. Foram obtidos valores da ordem de $R \$ 30,00$ a $R \$ 60,00$, sendo menos custosos que as destinações atualmente realizadas. Esta opção se apresenta como uma valorização interessante ao resíduo sólido de galvanoplastia das empresas de cromação da zona leste do município de São Paulo. 


\section{CONCLUSÕES}

O levantamento de dados realizado por meio da aplicação do questionário estruturado nas empresas de galvanoplastia da zona leste da cidade de São Paulo se mostrou eficiente para a obtenção das informações socioeconômicas, de processo produtivo e que influenciam a geração e a destinação dos resíduos sólidos.

A compilação dos dados obtidos com os questionários permitiu avaliar que praticamente todas as empresas consultadas são de micro ou pequeno porte e armazenam os resíduos sólidos em condições precárias, aumentando o risco de contaminação do meio ambiente.

As 17 empresas consultadas, situadas numa região extremamente povoada, geram um montante de aproximadamente 106 toneladas de resíduos sólidos galvânicos por ano, totalizando aproximadamente 190 toneladas por ano no setor de cromação atuante nesta região da cidade.

A maioria das indústrias consultadas contrata empresas especializadas para destinar os resíduos sólidos, representando um avanço ambiental para o setor, porém, deixando por resolver a questão do passivo ambiental criado, ainda que por tempo limitado, até a destinação.

Conclui-se que deveria haver ações dos órgãos governamentais para a retirada destes resíduos sólidos de dentro das empresas de galvanoplastia, para prevenir o ambiente e a saúde humana de possíveis contaminações.

As análises químicas comprovaram a periculosidade destes resíduos e revelaram que são constituídos principalmente por $\mathrm{Ni}, \mathrm{Cr}, \mathrm{B}, \mathrm{Cu}, \mathrm{Ca}, \mathrm{S}, \mathrm{C}, \mathrm{Na}, \mathrm{Fe}$ e $\mathrm{Zn}$. As análises físico-químicas mostraram que os resíduos são ordenados estruturalmente como aglomerados sólidos e, quando aquecidos até $1400^{\circ} \mathrm{C}$, apresentam formações de compostos que podem ser utilizados como matériasprimas para a produção de diversos produtos cerâmicos.

Com os procedimentos otimizados, os resíduos puderam ser utilizados para a elaboração de fritas cerâmicas e vidros a base de silicatos. Com as formulações ajustadas, foi possível obter materiais vítreos a partir do líquido fundido a $1300^{\circ} \mathrm{C} / 2 \mathrm{~h}$ e a $1500^{\circ} \mathrm{C} / 3 \mathrm{~h}$.

Os resíduos sólidos galvânicos foram incorporados em fritas e vidros, apresentando resultados satisfatórios para a inertização dos compostos nocivos à 
saúde e demonstrando ser uma valorização interessante tanto em aspectos técnicos como econômicos. Os vidros coloridos podem ser utilizados em segmentos específicos e as fritas podem ser utilizadas para a produção de esmaltes cerâmicos e de diversos outros produtos cerâmicos. 


\section{SUGESTÕES DE TRABALHOS FUTUROS}

1) Ampliar o levantamento de dados nas empresas de galvanoplastia, buscando avaliar o descarte direto de efluentes contaminados em mananciais dentro da própria cidade de São Paulo;

2) Estudar a estabilidade dos vidros silicatos, com resíduos sólidos galvânicos incorporados, em ambientes e soluções agressivas;

3) Desenvolver esmaltes cerâmicos e pigmentos inorgânicos a partir das fritas obtidas com incorporação dos resíduos sólidos galvânicos;

4) Avaliar o posicionamento dos principais metais na estrutura dos vidrosilicatos. 


\section{APÊNDICE - QUESTIONÁRIO ESTRUTURADO APLICADO NAS EMPRESAS DE GALVANOPLASTIA}

\section{IPEN - Mestrado - Cleiton dos Santos Mattos \\ QUESTIONÁRIO PARA GALVANOPLASTIAS - CROMAÇÕES}

\section{Dados cadastrais da empresa}

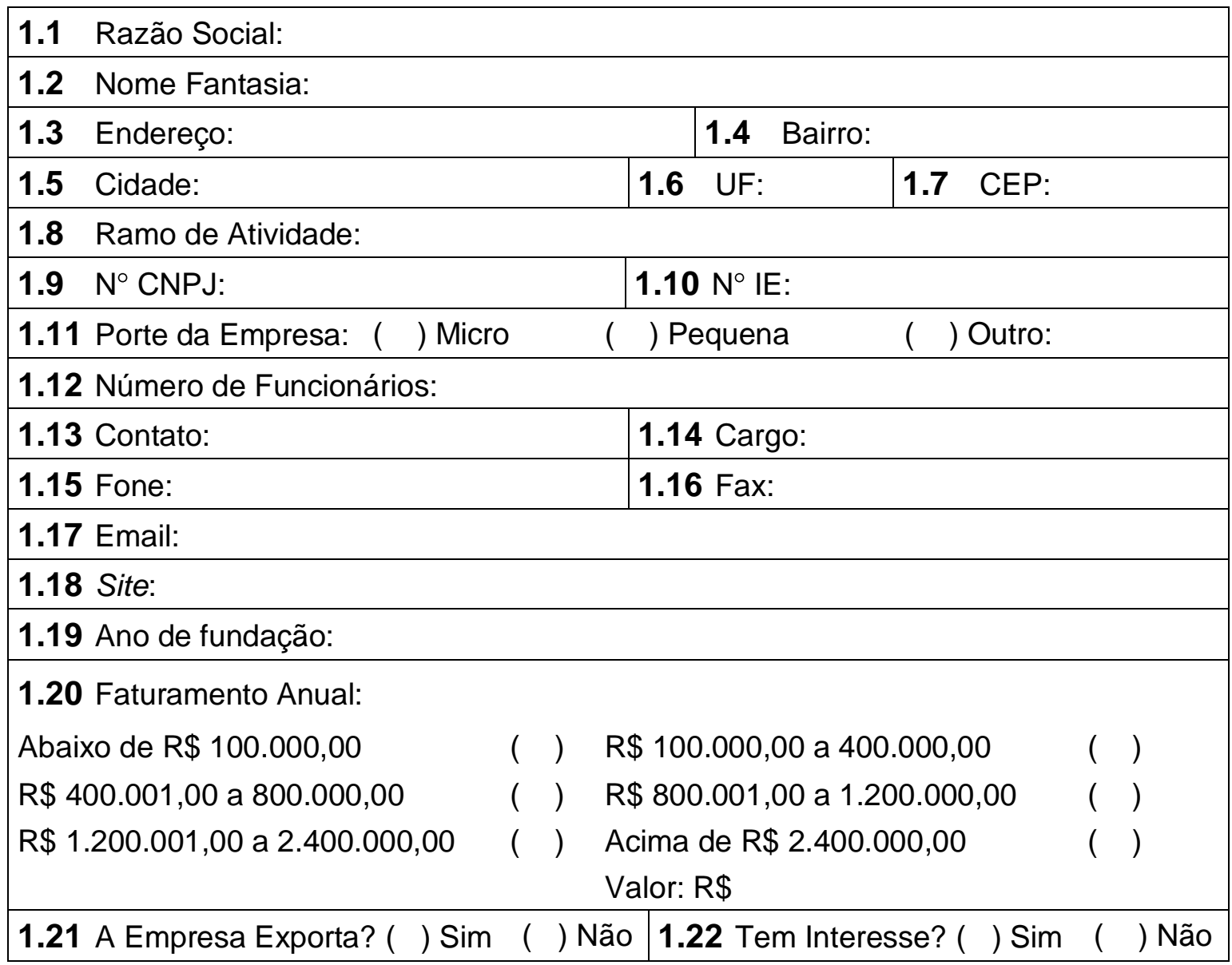

\section{Características do processo produtivo}

\subsection{Tipo do processo produtivo}
( ) Cromação
( ) Niquelação
( ) Cobreação
( ) Zincagem
( ) Estanhagem
( ) Latonagem
( ) Douração
( ) Prateação

( ) Banhos liga. Quais:

( ) Banhos químicos. Quais:
( ) Pintura eletrostática
( ) Pintura eletrolítica
( ) Pintura líquida
( ) Oxidação negra
( ) Envelhecimento
( ) Metalização
( ) Eletropolimento
( ) Outros. Quais: 


\subsection{Banhos existentes na empresa}
( ) Desengraxante
( ) Decapante
( ) Cobre alcalino
( ) Cobre ácido
( ) Níquel Watts
( ) Cromo decorativo
( ) Cromo duro
( ) Latão
( ) Grafite
( ) Zinco alcalino com cianeto
( ) Zinco alcalino sem cianeto
( ) Zinco ácido
( ) Estanho alcalino
( ) Estanho ácido
( ) Pré ouro
( ) Ouro folheação
( ) Ouro-cor
( ) Prata
( ) Ródio
( ) Outros. Quais:

2.3 Substratos (materiais-base) utilizados pela empresa (indicar a porcentagem)
( ) Latão
( ) Aço-carbono
( ) Ferro fundido
( ) Bronze
( ) Zamak
( ) Cobre
( ) Alumínio
( ) Aço-inoxidável
( ) Liga baixa-fusão (liga 88)
( ) Plásticos. Quais:
( ) Outros. Quais:

\subsection{Quantidade de peças revestidas por mês}

$\begin{array}{lllll}\text { ( ) } 0,0 \mathrm{t} \text { a } 0,5 \mathrm{t} & \text { ( ) } 0,6 \mathrm{ta} 1,0 \mathrm{t} & \text { ( ) } 1,1 \mathrm{ta} 2,0 \mathrm{t} & \text { ( ) } 2,1 \mathrm{t} \text { a } 5 \mathrm{t} & \text { ( ) } 6 \mathrm{ta} 10,0 \mathrm{t}\end{array}$

$\begin{array}{lllll}\text { ( ) } 11 \mathrm{ta} 20 \mathrm{t} & \text { ( ) } 21 \mathrm{ta} 50 \mathrm{t} & \text { ( ) } 51 \mathrm{ta} 100 \mathrm{t} & \text { ( ) } 101 \mathrm{t} \text { a } 200 \mathrm{t}\end{array}$

( ) 0 a 100.000 peças ( ) 100.001 a 200.000 peças ( ) 200.001 a 500.000 peças

( ) 500.001 a 1.000 .000 peças ( ) 1.000 .001 a 2.000 .000 peças

\section{Quantidade exata $=$}

\subsection{Número de funcionários na produção}
( ) 0 a 30
( ) 31 a 60
( ) 61 a 100
( ) 101 a 150
( ) 151 a 300

\section{Quantidade exata $=$}




\subsection{Descrição geral do processo (numerar pela ordem)}

( ) Aquisição de matéria-prima ( ) Colocação das peças em gancheiras

( ) Colocação das peças em tambores rotativos ( ) Desengraxe ( ) Lavagem 1

( ) Lavagem 2 ( ) Ativação ácida ( ) Lavagem 3 ( ) Lavagem 4 ( ) Decapagem

( ) Lavagem 1 ( ) Lavagem 2 ( ) Ativação ácida ( ) Lavagem 3 ( ) Lavagem 4

( ) Banho de cobre alcalino ( ) Água de arraste ( ) Lavagem 1 ( ) Lavagem 2

( ) Ativação ácida ( ) Lavagem 3 ( ) Lavagem 4 ( ) Banho de cobre ácido

( ) Água de arraste ( ) Lavagem 1 ( ) Lavagem 2 ( ) Ativação ácida ( ) Lavagem 3

( ) Lavagem 4 ( ) Banho de níquel ( ) Água de arraste ( ) Lavagem 1

( ) Lavagem 2 ( ) Ativação ácida ( ) Lavagem 3 ( ) Lavagem 4

( ) Banho de cromo decorativo ( ) Água de arraste ( ) Lavagem 1

( ) Lavagem 2 ( ) Lavagem 3 ( ) Lavagem 4 ( ) Lavagem com água quente

( ) Secagem ( ) Embalagem ( ) Expedição

( ) Outros. Quais:

\subsection{Equipamentos}

( ) Tanques ( ) Tambores rotativos ( ) Retificadores ( ) Centrífugas ( ) Bombas-filtro

( ) Exaustores ( ) Estufas ( ) Balança ( )pHmetro ( ) Termômetro ( ) Deionizador

( ) Ultrassom ( ) Medidor de espessura ( ) Paquímetro ( ) Micrômetro

( ) Lavador de gases ( ) Filtro-prensa

( ) Outros. Quais:

2.8 Insumos de produção (água e luz)

\begin{tabular}{|c|c|c|l|c|}
\hline Insumo & Tipo & Fornecedor & Custo/unid. (R\$) & Consumo mensal (unid.) \\
\hline Energia & $\mathrm{kWh}$ & Eletropaulo & & \\
\hline Água & $\mathrm{m}^{3}$ & SABESP & & \\
\hline
\end{tabular}

Observações: $\left(^{\star}\right)$ Dados não informados; $\left({ }^{\star \star}\right)$ Dados estimados em conjunto com a empresa. 
2.9 Índice de rejeição de lotes ou peças pelos clientes por mês
( ) $0 \%$ a $2,5 \%$
( ) $2,6 \%$ a $5,0 \%$
( ) $5,1 \%$ a $7,5 \%$
( ) $7,6 \%$ a $10 \%$
( ) $11 \%$ a $15 \%$
( ) $16 \%$ a $20 \%$
( ) $21 \%$ a $30 \%$
( ) $31 \%$ a $40 \%$
( ) $41 \%$ a $50 \%$
( ) $51 \%$ a $60 \%$
( ) $61 \%$ a $70 \%$
( ) $71 \%$ a $80 \%$
( ) $81 \%$ a $90 \%$
( ) $91 \%$ a $100 \%$

Quantidade exata $=$

2.10 Utilização da capacidade instalada
( ) $0 \%$ a $10 \%$
( ) $11 \%$ a $20 \%$
( ) $21 \%$ a $30 \%$
( ) $31 \%$ a $40 \%$
( ) $41 \%$ a $50 \%$
( ) $51 \%$ a $60 \%$
( ) $61 \%$ a $70 \%$
( ) $71 \%$ a $80 \%$
( ) $81 \%$ a $90 \%$
( ) $91 \%$ a $100 \%$

\section{Quantidade exata =}

\subsection{Descrição do Sistema da Qualidade}

( ) ISO $9001 / 2008$

( ) ISO 14001/2004

( ) Outro Sistema da Qualidade. Qual:

( ) Não possui Sistema da Qualidade

( ) Sistema da Qualidade em implantação

2.12 Descrição do controle de perdas no processo (peças que não podem ser retrabalhadas e arraste dos banhos)
( ) $0 \%$ a $2,5 \%$
( ) $2,6 \%$ a $5,0 \%$
( ) $5,1 \%$ a $7,5 \%$
( ) $7,6 \%$ a $10 \%$
( ) $11 \%$ a $15 \%$
( ) $16 \%$ a $20 \%$
( ) $21 \%$ a $30 \%$
( ) $31 \%$ a $40 \%$
( ) $41 \%$ a $50 \%$
( ) $51 \%$ a $60 \%$
( ) $61 \%$ a $70 \%$
( ) $71 \%$ a $80 \%$
( ) $81 \%$ a $90 \%$
( ) $91 \%$ a $100 \%$

Quantidade exata $=$ 


\subsection{Descrição do índice de refugos}

\subsection{1 Índice do consumo de matéria-prima reutilizada.*}

*Matéria-prima reutilizada: a que provém de peças refugadas da própria empresa.

( ) Reutiliza peças para refundição

( ) Reutiliza águas de lavagem - sistema de cascata

( ) Reutiliza águas de lavagem nos banhos

( ) Reutiliza água do tratamento de efluentes nos banhos

( ) Não reutiliza a própria matéria-prima no processo

( ) Outras reutilizações. Quais:

\subsection{2 Índice do consumo de matéria-prima reciclada/reaproveitadas de outras empresas $^{\star *}$}

** Matéria-prima reciclada: a que provêm de compra de "sucateiros", por exemplo.

( ) Utiliza peças de sucata

( ) Utiliza papel reciclado

( ) Outras utilizações de reciclados. Quais:

( ) Não utiliza matéria-prima reciclada de outras empresas

\subsection{4 Índice de retrabalho}
( ) $0 \%$ a $2,5 \%$
( ) $2,6 \%$ a $5,0 \%$
( ) $5,1 \%$ a $7,5 \%$
( ) $7,6 \%$ a $10 \%$
( ) $11 \%$ a $15 \%$
( ) $16 \%$ a $20 \%$
( ) $21 \%$ a $30 \%$
( ) $31 \%$ a $40 \%$
( ) $41 \%$ a $50 \%$
( ) $51 \%$ a $60 \%$
( ) $61 \%$ a $70 \%$
( ) $71 \%$ a $80 \%$
( ) $81 \%$ a $90 \%$
( ) $91 \%$ a $100 \%$

\section{Quantidade exata $=$}

\subsection{Produtos fabricados e mercados a que se destinam}

\begin{tabular}{|l|l|l|}
\hline Produto & Quantidade produzida por mês & Mercado \\
\hline & & \\
\hline & & \\
\hline
\end{tabular}




\section{A empresa possui Estação de Tratamento de Efluentes (ETE)?}
( ) Sim
( ) Não
( ) Em implantação

4 Quais líquidos são canalizados diretamente para a ETE?
( ) Desengraxante
( ) Decapante
( ) Lavagens
( ) Cobre alcalino
( ) Cobre ácido
( ) Níquel Watts
( ) Cromo decorativo
( ) Cromo duro
( ) Latão
( ) Grafite
( ) Zinco alcalino com cianeto
( ) Zinco alcalino sem cianeto
( ) Zinco ácido
( ) Estanho alcalino
( ) Estanho ácido
( ) Pré ouro
( ) Ródio
( ) Ouro folheação
( ) Ouro-cor
( ) Prata
( ) Outros. Quais:

\section{Qual o processo (etapas) da ETE?}

Separação das águas para tratamento:

( ) Tanque para ácidos

( ) Tanque para alcalinos

( ) Tanque para cromo

Processo:

( ) Oxidação do cianeto (hipofosfito de sódio)

( ) Redução do cromo hexavalente (metabissulfito de sódio)

( ) Redução de sulfato (carbonato de bário)

( ) Quebra de emulsão de óleo solúvel

( ) Neutralização (leite de cal, soda cáustica, carbonato de sódio ou óxido de magnésio)

( ) Ajuste de pH (ácido sulfúrico)

( ) Coagulação (sulfato de alumínio ou cloreto férrico)

( ) Floculação (polieletrólitos)

( ) Sedimentação / Decantação

( ) Filtração

( ) Outros. Quais: 


\section{Como é realizado o processo de secagem do resíduo sólido?}

( ) A lama é seca ao ar, em leito de secagem, num espaço descoberto

( ) A lama é seca ao ar, em leito de secagem, num espaço coberto

( ) A lama é seca em filtro-prensa

( ) A lama é colocada em tambores

( ) Outros. Quais:

7 Qual a provável porcentagem de líquido no resíduo sólido?

( ) Totalmente seco

( ) Parcialmente seco. Porcentagem de água: ( ) 10\% ( ) 20\% ( ) 30\% ( ) 40\% ( ) $50 \%$

( ) Não avaliado

8 efluente é analisado quimicamente? Quem realiza a análise?
( ) Sim. Empresa que realiza a análise:
( ) Não

Critério:

( ) Segundo Artigo 18 do Decreto 8.468, de 08/09/1976, que aprova o regulamento da Lei 997, de 31/05/1976 - CETESB

( ) Segundo Artigo 19A do Decreto 8.468, de 08/09/1976, que aprova o regulamento da Lei 997, de 31/05/1976 - CETESB

( ) Segundo Artigo 34 da Resolução n 357, de 17/03/2005 - CONAMA

9 O resíduo sólido é ou já foi analisado? Quem realiza ou realizou a análise?
( ) Sim. Empresa que realiza(ou) a análise:
( ) Não

10 Quais os prováveis componentes presentes nos resíduos sólidos gerados pela empresa?
( ) Cobre
( ) Níquel
( ) Cromo
( ) Zinco
( ) Estanho
( ) Ouro
( ) Prata
( ) Ródio
( ) Ferro
( ) Chumbo
( ) Cádmio
( ) Bromo
( ) Soda
( ) Sulfato
( ) Cianato
( ) Óleo
( ) Outros. Quais: 
11 Qual a quantidade de resíduos sólidos gerados por ano?
( ) $0 \mathrm{~kg} \mathrm{a} 500 \mathrm{~kg}$
( ) $501 \mathrm{~kg}$ a $1.000 \mathrm{~kg}$
( ) $1.001 \mathrm{~kg}$ a $2.000 \mathrm{~kg}$
( ) $2.001 \mathrm{~kg}$ a $3.000 \mathrm{~kg}$
( ) $3.001 \mathrm{~kg} \mathrm{a} 4.000 \mathrm{~kg}$
( ) $4.001 \mathrm{~kg}$ a $5.000 \mathrm{~kg}$
( ) $5.001 \mathrm{~kg} \mathrm{a} 6.000 \mathrm{~kg}$
( ) $6.001 \mathrm{~kg}$ a $7.000 \mathrm{~kg}$
( ) $7.001 \mathrm{~kg} \mathrm{a} 8.000 \mathrm{~kg}$
( ) $8.001 \mathrm{~kg} \mathrm{a} 9.000 \mathrm{~kg}$
( ) $9.001 \mathrm{~kg} \mathrm{a} 10.000 \mathrm{~kg}$
( ) $10.001 \mathrm{~kg}$ a $20.000 \mathrm{~kg}$
( ) 20.001 a $50.000 \mathrm{~kg}$

Quantidade exata $=$

12 Qual a destinação dada ao resíduo sólido?

( ) Estocagem na própria empresa

( ) Contratação de empresa especializada para realizar a destinação

( ) Outra. Qual:

13 Qual empresa retira o resíduo sólido e qual a periodicidade?

Empresa de coleta:

Periodicidade:

14 Qual o valor pago para a destinação dada atualmente?
( ) $R \$ 100,00 /$ t a $R \$ 300,00 / t$
( ) $R \$ 301,00 /$ t a $R \$ 500,00 / t$
( ) $R \$ 501,00 / t$ a $R \$ 750,00 / t$
( ) $R \$ 751,00 /$ a $R \$ 1.000,00 / t$
( ) $\mathrm{R} \$ 1.001,00 / \mathrm{t}$ a $\mathrm{R} \$ 1.500,00 / \mathrm{t}$
( ) $R \$ 1.501,00 /$ t a $R \$ 2.000,00 / t$
Quantidade exata =

15 Qual a destinação dada ao resíduo sólido pelas empresas especializadas?
( ) Aterro
( ) Reciclagem
( ) Incineração
( ) Coprocessamento
( ) Microencapsulação
( ) Outra. Qual:
( ) Não sabe 
16 Quais os problemas da armazenagem dos resíduos sólidos na empresa, ainda que até a sua destinação?

$\begin{array}{lll}\text { ( ) Ocupa espaço ( ) Atrapalha a produção } & \text { ( ) Risco de vazamento }\end{array}$

( ) Gasto com tambores ( ) Gasto com mão-de-obra extra ( ) Pagto de hora-extra

( ) Risco de fiscalização ( ) Risco de roubo

( ) Outros. Quais:

17 Visando o setor de cromação, qual o tipo de destinação seria mais adequado para os resíduos sólidos?

18 Aceita menção do nome da empresa no trabalho? 


\section{REFERÊNCIAS BIBLIOGRÁFICAS}

1 POPULAÇÃO MUNDIAL CHEGARÁ A 7 BILHÕES NO PRÓXIMO ANO. Veja Notícias: Abril. 30 jul. 2010. Disponível em:

$<$ http://veja.abril.com.br/noticia/economia/populacao-mundial-chegara-a-7bilhoes-no-proximo-ano>. Acesso em: 15 fev. 2011.

2 MELCHERT, W.R. Desenvolvimento de procedimentos analíticos limpos em sistemas de análises em fluxo para determinação de espécies de interesse ambiental. 2005. Dissertação (Mestrado) - Instituto de Química, São Paulo.

3 YOUNG, C.E.F.; LUSTOSA, M.C.J. Meio ambiente e competitividade na indústria brasileira. Disponível em:

<http://www.ie.ufrj.br/revista/pdfs/meio_ambiente_e_competitividade_na_ industria_brasileira.pdf>. Acesso em: 14 fev. $200 \overline{8}$.

4 INTERNATIONAL ORGANIZATION FOR STANDARDIZATION (ISO) Disponível em: <www.iso.org/iso>. Acesso em: 12 jan. 2011.

5 ANASTAS, P.T.; KIRCHHOFF, M.M. Origins, current status, and future challenges of green chemistry. Acc. Chem. Res., v. 35, p. 686, 2002.

6 LENARDÃO, E.J.; FREITAG, R.A.; DABDOUB, M.J.; BATISTA, A.C.F.; SILVEIRA, C.C. Green Chemistry - Os 12 princípios da Química Verde e sua inserção nas atividades de ensino e pesquisa. Quím. Nova, v. 26, p. 123, 2003.

7 U.S. ENVIRONMENTAL PROTECTION AGENCY (EPA). Disponível em: <http://www.epa.gov>. Acesso em: 12 jan. 2011.

8 ANASTAS, P.T. Green Chemistry: Theory and Practice. Oxford: University Press, 1998. 152p. ISBN 01-9850-698-8.

9 ROCHA, F.R.P.; NÓBREGA, J.A.; FATIBELLO FILHO, O. Flow analysis strategies to greener analytical chemistry. An overview. Green Chem., v. 3, p. 216-220, 2001.

${ }^{10}$ COMPANHIA DE TECNOLOGIA DE SANEAMENTO AMBIENTAL (CETESB). Bijuterias. São Paulo, 2005. 54p. (Série P+L).

${ }^{11}$ COMPANHIA DE TECNOLOGIA DE SANEAMENTO AMBIENTAL (CETESB). Resíduos sólidos - Introdução. Disponível em: <http://www.cetesb.sp.gov.br/residuos-solidos/Resíduos-Urbanos/1Introdução>. Acesso em: 22 fev. 2008. 
12 ASSOCIAÇÃO BRASILEIRA DE NORMAS TÉCNICAS (ABNT). NBR 10.004: Resíduos sólidos - Classificação. Rio de Janeiro, 2004, 71p.

${ }^{13}$ ASSOCIAÇÃO BRASILEIRA DE NORMAS TÉCNICAS (ABNT). NBR 10.005: Procedimento para obtenção de extrato lixiviado de resíduos sólidos. Rio de Janeiro, 2004, 16p.

${ }^{14}$ ASSOCIAÇÃO BRASILEIRA DE NORMAS TÉCNICAS (ABNT). NBR 10.006: Procedimento para obtenção de extrato solubilizado de resíduos sólidos. Rio de Janeiro, 2004, 3p.

${ }^{15}$ ASSOCIAÇÃO BRASILEIRA DE NORMAS TÉCNICAS (ABNT). NBR 10.007: Amostragem de resíduos sólidos. Rio de Janeiro, 2004, 21p.

${ }^{16}$ COMPANHIA DE TECNOLOGIA DE SANEAMENTO AMBIENTAL (CETESB). Resíduos sólidos industriais. Disponível em: <http://www.cetesb.sp.gov.br/residuos-solidos/residuos-urbanos/3-residuossolidos-industriais >. Acesso em: 22 fev. 2008.

${ }^{17}$ LIMA PEREIRA, R. Alternativas das indústrias para tratar seus resíduos. Revista Saneamento Ambiental, n. 40, p. 20-27, 1998.

18 VELOSO, R.; ARTURO, E. Reator térmico inertizante. In: INTERNACIONAL WORKSHOP ADVANCES IN CLEANER PRODUCTION, 1 st., 2007, São Paulo. Proceedings... $30 \mathrm{p}$. Disponível em: <http://www.advancesincleanerproduction.net/textos\%20e\%20arquivos/ sessoes/5b/5/Emilio\%20Arturo\%20Rojas\%20Veloso\%20\%20Resumo\%20Exp..doc>. Acesso em: 07 fev. 2008.

19 SERVIÇO NACIONAL DE APRENDIZAGEM INDUSTRIAL (SENAI). Manual de orientações básicas para a minimização de efluentes e resíduos na indústria galvânica. Porto Alegre, 2000. 64p.

${ }^{20}$ ESSENCIS SOLUÇÕES AMBIENTAIS. Aterro Classe I E II. Disponível em: $<$ http://www.essencis.com.br/solucoes-ambientais/tratamento-e-destinacao-deresiduos/aterro-classe-i-e-ii . Acesso em: 10 fev. 2011.

${ }^{21}$ O destino do lixo perigoso. O Estado de São Paulo, São Paulo, 15 fev. 2000, p. A3. 
22 DASKALOPOULOS, E.; BADR, O.; PROBERT, S.D. Economic and environmental evaluations of waste treatment and disposal technologies for municipal solid waste. Applied Energy, v. 58, n. 4, p. 209-255, 1997.

${ }^{23}$ ESSENCIS SOLUÇÕES AMBIENTAIS. Incineração. Disponível em: $<$ http://www.essencis.com.br/solucoes-ambientais/tratamento-e-destinacao-deresiduos/incineracao >. Acesso em: 10 fev. 2011.

${ }^{24}$ ALVEZ, F. O que está sendo feito com os resíduos industriais? Revista Saneamento Ambiental, n. 54, p. 17-24, 1999.

${ }^{25}$ MENEZES, R.A.A; BESSA, I.; MENEZES, M.A. O plasma térmico - Solução final para os resíduos perigos. In: SEMINÁRIO DE MEIO AMBIENTE ASSOCIAÇÃO BRASILEIRA DE METALURGIA E MATERIAIS, 1999, São Paulo. Anais... 21p.

${ }^{26}$ MILANEZ, K.W.; KNIESS, C.T.; BERNARDIN, A.M.; RIELLA, H.G.; KUHNEN, N.C. Caracterização de pigmentos inorgânicos à base de $\mathrm{Fe}, \mathrm{Zn}$, e $\mathrm{Cr}$ utilizando resíduo de galvanoplastia como matéria-prima. Cerâmica, v. 51, n. 318, p. 107-110, 2005.

${ }^{27}$ BASEGIO, T.M.; VILLANOVA, D.L.; BERGMANN, C.P. Obtenção de produtos cerâmicos convencionais a base de lodo galvânico. In: 51ํㅡㄴ CONGRESSO BRASILEIRO DE CERÂMICA, 2007, Bahia. Anais... 12 p. Disponível em: <http://www.abceram.org.br/51cbc/artigos/51cbc-14-47.pdf>. Acesso em: 22 fev. 2008.

${ }^{28}$ MAGALHÃES, J.M.; SILVA, J.E.; CASTRO, F.P.; LABRINCHA, J.A. Effect of experimental variables on the inertization of galvanic sludges in clay-based ceramics. Journal of Hazardous Materials, v. 106B, p. 139-147, 2004.

${ }^{29}$ LUZ, C.A.; ROCHA, J.C.; CHERIAF, M.; PERA, J. Use of sulfoaluminate cement and bottom ash in the solidification/stabilization of galvanic sludge. Journal of Hazardous Materials, v. 136B, p. 837-845, 2006.

${ }^{30}$ SILVA, A.C.; MELLO-CASTANHO, S.R.H. Silicate glasses obtained from fine silica powder modified with galvanic waste addition. Journal Non-Crystalline Solids, v. 348, p. 211-217, 2004.

31 JANDOVÁ, J.; DVORÁK, P.; JIRICNÝ, V. Recovery of zinc from zinc waste galvanic sludges with increased copper and nickel content. In: REWAS'04 Global Symposium on Recycling, Waste Treatment and Clean Technology, 2005. Anais... p. 1883-1891. 
32 JANDOVA, J.; MAIXNER, J.; GRYGAR, T. Reprocessing of zinc galvanic waste sludge by selective precipitation. Ceramics - Silikaty, v. 46, n. 2, p. 52-55, 2002.

33 BARRERA-GODÍNEZ, J.A.; O'KEEFE, T.J. A continuous flow evaluation of the galvanic stripping process. Separation Science and Technology, v. 34, n. 12 , p. 2395-2405, 1999.

34 SIEBENHOFER, M.; SCHWEIGER, H.; LORBER, K. Upgrading of zinc from galvanic sludge and steel furnace dust. Separation Science and Technology, v. 32, n. 1-4, p. 759-773, 1997.

35 BROMBACHER, C.; BACHOFEN, R.; BRANDL, H. Biohydrometallurgical processing of solids: A patent review. Applied Microbiology and Biotechnology, v. 48, n. 5, p. 577-587, 1997.

${ }^{36}$ MOATS, M.S.; CHANG, C.M.; O'KEEFE, T.J. Recovery of zinc from residues by SX-galvanic stripping process. In: TMS FALL MEETING, 1995. Proceedings... p. 545-562.

37 CHAJKIN, V.A.; MYASTOVSKIJ, YU.N.; CHAJKIN, N.V.; Preparation of mineral powder for asphalt concrete from molding sand wastes. Litejnoe

Proizvodstvo, n. 4, p. 23-24, 2002.

${ }^{38}$ SILVA, A.C.; MELLO-CASTANHO, S.R.H. Vitrified galvanic waste chemical stability. Journal of the European Ceramic Society, v. 27, p. 565-570, 2007.

${ }^{39}$ MELLO-CASTANHO, S.R.H.; SILVA, A.C.; ESTEBAN-CUBILLO, A.; PECHARROMÁN, C.; MOYA, J.C. Glass silicate from $\mathrm{Cr}$ and $\mathrm{Ni}$ high level galvanic waste. Boletin de la Sociedad Espanhola de Ceramica y Vidrio, v. 45 , n. 1, p. 52-57, 2006.

40 MARIALVA-NETO, A.A.; CUNHA, S.M.; SILVA, A.C.; MELLO-CASTANHO, S.R.H. Solid galvanic wastes incorporation in glass matrices. Materials Science Forum, v. 498-499, p. 500-505, 2005.

${ }^{41}$ MAGALHÃES, J.M.; SILVA, J.E.; CASTRO, F.P.; LABRINCHA, J.A. Role of the mixing conditions and composition of galvanic sludges on the inertization process in clay-based ceramics. Journal of Hazardous Materials, v. 106B, p. 169-176, 2004.

42 CIOFFI, R.; LAVORGNA, M.; SANTORO, L. Environmental and technological effectiveness of a process for the stabilization of a galvanic sludge. Journal of Hazardous Materials, v. 89, n. 2-3, p. 165-175, 2002. 
PEREZ, J.A.; TERRADAS, R.; MANENT, M.R.M.; MARTINEZ, S. Inertization of industrial wastes in ceramics materials. Ceramurgia, v. 28, n. 1, p. 11-13, 1998.

44 PEREZ, J.A.; TERRADAS, R.; MANENT, M.R.M.; SEIJAS, M.; MARTINEZ, S. Inertization of industrial wastes in ceramics materials. Industrial Ceramics, v. 16, n. 1, p. 7-10, 1996.

45 NAVARRO, J.M.F. El vidrio. 3.ed. Madrid, Consejo Superior de Invest. Científicas - Fundacion Centro Nacional del vidrio, 2003.

46 PAUL, A. Chemistry of glasses. Londres, Inglaterra: Chapmam and Hall, 1982.

47 MARIALVA-NETO, A.A. Incorporação de residuos sólidos galvânicos em matrizes vítreas. São Paulo, Centro de Ciência e Tecnologia de Materiais IPEN, 2003. 85p. Dissertação (Mestrado).

48 SERVIÇO SOCIAL DA INDÚSTRIA (SESI). Manual de segurança e saúde no trabalho: Indústria galvânica. São Paulo, 2007. 260p. (Coleção Manuais).

49 FÖLDES, P.A. Galvanotécnica prática - 1. Galvanoplastia e 2. Metais acabamento. São Paulo: Polígono, Universidade de São Paulo, 1973.

50 KUSHNER, J. B. Electroplating know how II - A home study course in modern metal finishing - Lesson six - The plating baths, Part 1. Indiana, 1974.

51 LOWENHEIM, F. A. Modern electroplating. 3.ed. New York: John Wiley, 1974.

52 KUSHNER, J. B. Electroplating know how II - A home study course in modern metal finishing - Lesson eight - The plating baths (3). Indiana, 1974.

${ }^{53}$ KUSHNER, J. B. Electroplating know how II - A home study course in modern metal finishing - Lesson ten - The alloy plating baths (1). Indiana, 1974.

54 KUSHNER, J. B. Electroplating know how II - A home study course in modern metal finishing - Lesson nine - The plating baths (4). Indiana, 1974. 
${ }^{55}$ KUSHNER, J. B. Electroplating know how II - A home study course in modern metal finishing - Lesson seven - The plating baths (2). Indiana, 1974.

${ }^{56}$ KUSHNER, J. B. Electroplating know how II - A home study course in modern metal finishing - Lesson eleven - The alloy plating baths (2). Indiana, 1974.

${ }^{57}$ KUSHNER, J. B. Electroplating know how II - A home study course in modern metal finishing - Lesson fifteen - Anodic process: electropolishing, anodizing, electrochemical grinding, machining, corrosion. Indiana, 1974.

${ }^{58}$ KUSHNER, J. B. Electroplating know how II - A home study course in modern metal finishing - Lesson thirteen - Electroless plating, vacuum \& vapor plating, plating on non conductors. Indiana, 1974.

${ }^{59}$ KUSHNER, J. B. Electroplating know how II - A home study course in modern metal finishing - Lesson twelve - Chemical finishes (chromating, phosphating), metal coloring, lacquering, electropainting. Indiana, 1974.

${ }^{60}$ KUSHNER, J. B. Electroplating know how II - A home study course in modern metal finishing - Lesson three - Polishing and buffing. Indiana, 1974.

${ }^{61}$ KUSHNER, J. B. Electroplating know how II - A home study course in modern metal finishing - Lesson four - Cleaning and pickling. Indiana, 1974.

${ }^{62}$ KUSHNER, J. B. Electroplating know how II - A home study course in modern metal finishing - Lesson two - The basic principles of plating (2). Indiana, 1974.

${ }^{63}$ VALENZUELA, J. Tratamento de Efluentes em Indústrias Galvanotécnicas. São Paulo: Páginas \& Letras, 1999.

${ }^{64}$ SERVIÇO BRASILEIRO DE APOIO ÀS MICRO E PEQUENAS EMPRESAS DE SÃO PAULO (SEBRAE-SP). Micro e pequenas empresas em números.

Disponível em:

<http://www.sebraesp.com.br/TenhoUmaEmpresa/Biblioteca/OutrosConteudos/ EstudosEPesquisas/MPEsEmNumeros/Paginas/MPEsEmNumeros.aspx>. Acesso em: 14 jan. 2011. 
65 SEBRAE debate iniciativas de valorização no distrito de Itaquera. Folha Online, São Paulo, 03 jun. 2005. Disponível em:

<http://www1.folha.uol.com.br/folha/dimenstein/so_sp/gd030605.htm> Acesso em: 15 fev. 2008.

66 INSTITUTO BRASILEIRO DE GEOGRAFIA E ESTATÍSTICA (IBGE). Censo 2010: população do Brasil é de 190.732.694 pessoas. Disponível em: <http://www.ibge.gov.br/home/presidencia/noticias/noticia_visualiza.php?id_noti cia=1766\&id_pagina=1 >. Acesso em: 14 jan. 2011.

67 MATTOS, C.S.; MAZZARELLA, V.N.G.; NAGAMINE, R.; PANOSSIAN, Z.; GUERREIRO, R. Projeto Unidades Móveis de Atendimento Tecnológico. Corrosão e Proteção. Ano 4, n. 16, p. 20-21, jul/ago, 2007.

68 Construção de questionários. Disponível em: http://pt.shvoong.com/exactsciences/1881071-constru\%C3\%A7\%C3\%A3o-question\%C3\%A1rios/>. Acesso em: 14 jan. 2011.

69 SKOOG, A.D.; HOLLER, F.J.; NIEMAN, T.A. Princípios de análise instrumental. 5.ed., Bookman, 2008.

70 MANNING, T.J.; GROW, W.R. Inductively Coupled Plasma - Atomic Emission Spectrometry. The chemical education, v. 2, n. 1, 1997.

71 SKOOG, D.A.; WEST, D.M.; HOLLER, F.J. Fundamentos de química analítica, 8.ed., Thomson, 2008.

72 ATKINS, P.; JONES, L. Princípios de Química - Questionando a Vida Moderna e o Meio Ambiente. 3.ed. Bookman, 2007.

73 GOLDSTEIN, J.I. et. all Scanning electron microscopy and X-Ray microanalysis. 2.ed. Plenum Press, 1992.

${ }^{74}$ SILVA, A.C. Incorporação de resíduo galvânico em vidro silicato obtido a partir de finos de sílica. São Paulo, Centro de Ciência e Tecnologia de Materiais - IPEN, 2004. 90 p. Dissertação (Mestrado).

75 SILVA, A.C. Vidros e vitrocerâmicos com alta concentração de metais obtidos a partir de resíduos industriais. São Paulo, Centro de Ciência e Tecnologia de Materiais - IPEN, 2008. 177p. Tese (Doutorado).

76 ROTH, R.S.; NEGAS, T.; COOK, L.P. Phase diagrams for ceramists. v.4. Columbus, Ohio: The American Society, Inc, 1981. fig. 5321. 
77 SERVIÇO NACIONAL DE APRENDIZAGEM INDUSTRIAL (SENAI). Manual de orientações básicas para a minimização de efluentes e resíduos na indústria galvânica. Porto Alegre, 2000.64p.

78 ASSOCIAÇÃO BRASILEIRA DE NORMAS TÉCNICAS (ABNT). NBR 12235: Armazenamento de resíduos sólidos perigosos - Procedimento. Rio de Janeiro, 1992. 14p.

79 ROBERT, C.; WEAST, Ph. D. CRC Handbook of Chemistry and Physics. 58.ed. Cleveland, Ohio: CRC Press, Inc, 1977-1978.

80 INTERNATIONAL CENTRE FOR DIFFRACTION DATA (ICDD). Banco de dados em Powder diffraction file 2 (PDF-2), versão 2003. 